\title{
Taming an ichnotaxonomical Pandora's box: revision of dendritic and rosetted microborings (ichnofamily: Dendrinidae)
}

\author{
Max WISSHAK \\ Senckenberg am Meer, Marine Research Department, 26382 Wilhelmshaven, Germany. \\ Email:max.wisshak@senckenberg.de
}

urn:1sid:zoobank.org:author:C0BEC6E9-968A-43ED-B31E-015D97DEC3A3

\begin{abstract}
Dendritic and/or rosetted microborings in calcareous and osteic skeletal substrates have a diverse trace fossil record, spanning most of the Phanerozoic, whereas the ichnodiversity of comparable bioerosion traces produced in modern seas is rather limited. The most prominent occurrences are known from Devonian brachiopods and from Upper Cretaceous belemnite rostra. Ichnotaxonomically, they are comprised within one of the few ichnofamilies established to date, the Dendrinidae Bromley et al., 2007. As an outcome of the present revision of this ichnofamily, the plethora of 84 ichnospecies established within 25 ichnogenera since the erection of the type ichnogenus Dendrina Quenstedt, 1849 was considerably condensed to 22 ichnospecies included in 7 ichnogenera, based on a coherent morphological categorisation and ichnotaxobasis assessment. The suite of ichnogenera now subsumed within the Dendrinidae includes Dendrina Quenstedt, 1849; Clionolithes Clarke, 1908; Calcideletrix Mägdefrau, 1937; Dictyoporus Mägdefrau, 1937; Abeliella Mägdefrau, 1937; Nododendrina Vogel et al., 1987; and Pyrodendrina Tapanila, 2008. New combinations thereby concern Dendrina dendrina (Morris, 1851) comb. nov., Clionolithes pannosus (Solle, 1938) comb. nov., C. alcicornis (Vogel et al., 1987) comb. nov., C. convexus (Hofmann, 1996) comb. nov., Calcideletrix anomala (Mägdefrau, 1937) comb. nov., C. fastigata (Radtke, 1991) comb. nov., Dictyoporus balani (Tavernier et al., 1992) comb. nov., Nododendrina europaea (Fischer, 1875) comb. nov., N. incomposita (Mägdefrau, 1937) comb. nov. and $N$. paleodendrica (Elias, 1957) comb. nov. Investigation of new material and a reassessment of 63 dendrinid microborings previously addressed in informal nomenclature allowed the establishment of two complementing ichnogenera, Rhopalondendrina igen. nov. and Antodendrina igen. nov., and eight new ichnospecies, comprising Pyrodendrina arctica isp. nov., P. belua isp. nov., $P$. villosa isp. nov., Rhopalondendrina avis igen. et isp. nov., $R$. acanthina igen. et isp. nov., $R$. contra igen. et isp. nov., $R$. tigris igen. et isp. nov. and Antodendrina ligula igen. et isp. nov. In densely bioeroded calcareous substrates, different dendrinids and other bioerosion traces may be found in direct contact with each other, forming composite trace fossils, but some of these associations appear rather systematic in nature and could be the work of the same tracemaker under different behavioural modes, thus forming compound trace fossils. In these cases, however, the distinction between the two concepts remains largely equivocal. Dendrinid microborings are primarily found in living and dead calcareous skeletal substrates of bivalves, brachiopods, belemnites and corals, with complementing records from six other substrate types. Facing considerable sampling artefacts, evidence for true substrate specificity or symbiotic relationships is inconclusive as yet, whereas there is direct evidence for post-mortem infestation in
\end{abstract}


several cases, such as the diverse dendrinid associations in Upper Cretaceous belemnite guards. Despite a wealth of available interpretations, the actual biological identity of the dendrinids' tracemakers remains largely speculative. The most convincing evidence has been put forward in support of foraminiferans as the producers of Nododendrina, and excavating micro-sponges producing Clionolithes and some Calcideletrix. Since most of the dendrinids are found in aphotic (palaeo-)environments, these two principal types of organotrophic tracemakers are also potential candidates for the other ichnogenera. With regards to evolutionary patterns through geologic time, strong adaptive radiations are evident from the ichnodiversity of dendrinid ichnospecies in the Early to Mid-Palaeozoic, reflecting the "Ordovician Bioerosion Revolution" (sensu Wilson \& Palmer 2006) and the "Mid-Palaeozoic Precursor of the Mesozoic Marine Revolution" (sensu Signor \& Brett 1984), respectively, and in the Mesozoic, coinciding with the prominent "Marine Mesozoic Revolution" (sensu Vermeij 1977). This pattern mimics that of other micro- and macro-bioerosion trace fossils and is interpreted as a reflection of increased predation pressure and consequent infaunalisation. For extinction events, in turn, a differential effect is recorded in that the first four of the "Big Five" mass extinctions appear not to have had any noticeable effect on dendrinid ichnodiversity, whereas the end-Cretaceous mass-extinction resulted in a 77\% drop following the Cretaceous peak ichnodiversity of 13 dendrinid ichnospecies.

Keywords. Bioerosion, trace fossils, microborings, dendrinids, Dendrinidae, ichnotaxonomy.

Wisshak M. 2017. Taming an ichnotaxonomical Pandora's box: revision of dendritic and rosetted microborings (ichnofamily: Dendrinidae). European Journal of Taxonomy 390: 1-99. https://doi.org/10.5852/ejt.2017.390

\section{Introduction}

Rosetted bioerosion traces are subsumed within the ichnofamily Dendrinidae, defined by Bromley et al. (2007) as "microborings having a rosetted or incompletely rosetted (i.e., fan-shaped) morphology, with or without a central or marginal main chamber". They are also addressed as dendrinid microborings, or simply as dendrinids, referring both to the type ichnogenus Dendrina Quenstedt, 1849 and the ichnofamily name, and/or referring to their dendritic branching pattern. Following the original ichnofamily diagnosis and acknowledging the minute size of these complex bioerosion traces, we herein consider dendrinids as microborings, despite being aware that large forms may reach up to $6 \mathrm{~mm}$ in diameter, thus extending into the size range of macroborings (traces > $1 \mathrm{~mm}$ in diameter sensu Knaust 2012 and Wisshak 2012).

The most closely related microborings are radial microborings produced by algae and cyanobacteria, such as the ichnogenera Rhopalia Radtke, 1991 and Fascichnus Radtke \& Golubic, 2005, as well as camerate sponge macroborings of the most specious ichnogenus Entobia Bronn, 1837 and the ramified phoronid boring systems comprised within the ichnogenus Talpina von Hagenow, 1840. Within the dendrinids, there is a gradual transition from distinct and confined rosettes to more extended dendritic systems and anastomosing networks, partly complicating recognition of morphological limits of the ichnofamily. The suite of ichnogenera now subsumed within the Dendrinidae nevertheless coincides with the definition of the category "dendritic and rosetted borings" in the set of categories for architectural designs in trace fossils as defined by Buatois et al. (2017).

An extensive literature query for fossil and Recent dendrinid microborings yielded a total of 25 ichnogenera comprising 84 ichnospecies, complemented by 63 reports in the informal nomenclature. The morphological reminiscence among the established ichnospecies is considerable, implying a high proportion of synonymies and calling for the present revision of this conspicuous group of bioerosion traces. The process of tidying up this ichnotaxonomical Pandora's box faces nomenclatural and practical issues, such as (1) spanning 165 years of research across all cut-off dates in the turbulent development 
of ichnotaxonomy within and outside the International Code of Zoological Nomenclature (ICZN 1999), (2) lost, destroyed or inaccessible type material, (3) homonymies, (4) cases of incorrect spelling, (5) lack or inadequate designation of type ichnospecies or material, (6) a high proportion of monotypic ichnogenera, (7) many original publications in German or French, (8) original descriptions in unpublished theses, and last but not least (9) impeded comparability of material due to a wide range of fossil preservation (e.g., natural casts, resin casts, transparent host substrate and surface morphology only) and utilised methods of visualisation. These circumstances have led to the creation of a considerable number of nomina dubia, nomina nuda and junior synonyms. Consequently, the revised suite of ichnotaxa is considerably condensed to about one third, now comprising nine ichnogenera with a total of 30 ichnospecies (including the ichnotaxa newly described herein).

The approach of the present revision was to establish a coherent morphological categorisation and ichnotaxobasis assessment, based on which the existing plethora of dendrinid ichnotaxa could be lumped to a reduced suite of ichnogenera that are distinct by priority ichnotaxobases. This ordering and validation process was undertaken closely following the principles of the ICZN and promoting ichnotaxonomical stability. A re-investigation of the most relevant type material supported synonym recognition and morphological comparability. Following the revised ichnotaxonomy, those dendrinids previously addressed only via informal nomenclature were then identified as far as feasible, allowing for better assessment of the substrate specificity, the stratigraphical range and the evolutionary patterns of dendrinids, alongside a review and discussion of their most probable tracemakers.

\section{Material and methods}

This review is primarily based on a thorough reinvestigation of the relevant type material, which was either loaned for further investigation or studied as a series of images kindly provided by the responsible collection managers (Table 1). Some of the dendrinid type material, however, could not be located, despite extensive museum queries, and thus has to be considered as currently lost. This concerns Quenstedt's original material of Dendrina (Quenstedt 1849), all of the ichnospecies in Dendrina, Cobalia and Haguenowia described by Étallon (1859a, 1859b, 1862, 1864) and Thurman \& Étallon (1964), Dendrina europaea Fischer, 1875, Dendrina anomala Mägdefrau, 1938, Clionolithes pricei Branson, 1937, Clionolithes huannensis Chow, 1957, Cliona paleodendritica Elias, 1957, C. stellata Elias, 1957, C. fenestralis Elias, 1957 and Dendrorete balani Tavernier et al., 1992.

At the time of writing, negotiations were ongoing with respect to a transfer of the extensive material of microbioerosion trace fossils (including dozens of type specimens), compiled by the "Vogel Group" in Frankfurt, from the Institute of Geosciences at the Goethe University to the Senckenberg Institute. All of the investigated material from this collection is herein referred to with the original inventory numbers.

In addition, own material from previous studies was revisited (e.g., Wisshak et al. 2005a, 2005b, 2011; Wisshak 2006) and new material was investigated to solve some of the pending ichnotaxonomical issues. In this context, a large collection of Upper Cretaceous belemnites, brachiopods, bivalves, fish teeth and other biogenic skeletal substrates was kindly provided by the ambitious private collector Peter Girod (Berlin, Germany).

Visualisation procedures comprised macrophotography (Nikon D700), digital microscopy (Keyence VHX-2000) and SEM (Tescan VEGA 3). Morphometrical measurements were carried out in plan or lateral views with the SEM software VEGA TC or the freeware image analysis tool ImageJ. 
Table 1. Studied material, listed by original ichnotaxon nomen and in order of publication date, with specification of collection, inventory number and investigation methods. Present type assignments: $\mathrm{H}=$ holotype, $\mathrm{P}=$ paratype, $\mathrm{L}=$ lectotype, $\mathrm{PL}=$ paralectotype(s), $\mathrm{S}=$ syntype(s), $\mathrm{N}=$ neotype. Inventory numbers from the Institut für Geowissenschaften, Goethe-Universität, Frankfurt include the sample code on the stub in brackets. Continued on next page.

\begin{tabular}{|c|c|c|c|c|}
\hline Publication & Ichnotaxon & Inventory numbers & Collection & Comments \\
\hline $\begin{array}{l}\text { von Hagenow } \\
(1840)\end{array}$ & $\begin{array}{l}\text { Talpina ramosa } \\
\text { T. solitaria } \\
\text { Talpina ramosa } \\
\text { T. solitaria }\end{array}$ & $\begin{array}{l}\text { MB.Po } 2128.1(\mathrm{~L}) \\
\text { MB.W. } 0864(\mathrm{~L}+\mathrm{PL}) \\
\text { MMG: MvK } 530(\mathrm{PL}) \\
\text { MMG: MvK } 532(\mathrm{PL})\end{array}$ & $\begin{array}{l}\text { Museum für Naturkunde, Berlin, } \\
\text { Germany } \\
\text { Senckenberg Naturhistorische } \\
\text { Sammlungen, Dresden, Germany }\end{array}$ & $\begin{array}{l}\text { loaned for } \\
\text { macrophotography and } \\
\text { microscopy }\end{array}$ \\
\hline $\begin{array}{l}\text { von Hagenow } \\
\text { (unpubl.) }\end{array}$ & $\begin{array}{l}\text { Talpina foliacea } \\
\text { T. sentiformis } \\
\text { Talpina foliacea } \\
\text { T. sentiformis }\end{array}$ & $\begin{array}{l}\text { MB.Po } 2130.1-3(\mathrm{~S}) \\
\text { MB.W. } 0866(\mathrm{~S}) \\
\text { MMG: MvK } 529(\mathrm{~S}) \\
\text { MMG: MvK } 530(\mathrm{~S})\end{array}$ & $\begin{array}{l}\text { Museum für Naturkunde, Berlin, } \\
\text { Germany } \\
\text { Senckenberg Naturhistorische } \\
\text { Sammlungen, Dresden, Germany }\end{array}$ & $\begin{array}{l}\text { loaned for } \\
\text { macrophotography and } \\
\text { microscopy }\end{array}$ \\
\hline Morris (1851) & Talpina dendrina & PI A 559 (L+PL) & $\begin{array}{l}\text { Natural History Museum, } \\
\text { London, UK }\end{array}$ & $\begin{array}{l}\text { loaned for } \\
\text { macrophotography, } \\
\text { microscopy and } \mu \mathrm{CT}\end{array}$ \\
\hline Clarke (1908) & C.palmatus & $\begin{array}{l}6702(\mathrm{~L}+\mathrm{PL}) \\
6700(\mathrm{PL}) \\
6701 \\
6697(\mathrm{~L}) \\
6698(\mathrm{PL}) \\
\end{array}$ & $\begin{array}{l}\text { New York State Museum, New } \\
\text { York, USA }\end{array}$ & $\begin{array}{l}\text { series of images } \\
\text { provided by collection } \\
\text { manager }\end{array}$ \\
\hline Thomas (1911) & Clionolithes hackberryensis & $2807,2808,2809,2810(\mathrm{~S})$ & $\begin{array}{l}\text { Palaeontology depository, } \\
\text { University of Iowa, Iowa City, } \\
\text { USA }\end{array}$ & loaned for microscopy \\
\hline $\begin{array}{l}\text { Lees \& Thomas } \\
\text { (1918) }\end{array}$ & Clionolithes lizardensis & $2811,2812,2813(\mathrm{~S})$ & $\begin{array}{l}\text { Palaeontology depository, } \\
\text { University of Iowa, Iowa City, } \\
\text { USA }\end{array}$ & loaned for microscopy \\
\hline $\begin{array}{l}\text { Ruedemann } \\
(1925)\end{array}$ & Clionolithes quaerens & $6699(\mathrm{H})$ & $\begin{array}{l}\text { New York State Museum, Albany, } \\
\text { USA }\end{array}$ & $\begin{array}{l}\text { series of images } \\
\text { provided by collection } \\
\text { manager }\end{array}$ \\
\hline $\begin{array}{l}\text { Fenton \& Fenton } \\
\text { (1932) }\end{array}$ & $\begin{array}{l}\text { Clionolithes fossiger } \\
\text { C. hackberryensis }\end{array}$ & $\begin{array}{l}4811(\mathrm{H}) \\
4810,4812(\mathrm{P}) \\
4804,4805,4806,4807 \\
4808,4809\end{array}$ & $\begin{array}{l}\text { Carnegie Museum of Natural } \\
\text { History, Pittsburgh, USA }\end{array}$ & $\begin{array}{l}\text { series of images } \\
\text { provided by collection } \\
\text { manager }\end{array}$ \\
\hline & Clionolithes irregularis & PAL $84693(\mathrm{H})$ & $\begin{array}{l}\text { Smithsonian Institution, National } \\
\text { Museum of Natural History, } \\
\text { Washington DC, USA }\end{array}$ & loaned for microscopy \\
\hline $\begin{array}{l}\text { Mägdefrau } \\
\text { (1937) }\end{array}$ & $\begin{array}{l}\text { D. incomposita } \\
\text { D. minor } \\
\text { Calcideletrix flexuosa } \\
\text { C. breviramosa } \\
\text { Dictyoporus nodosus } \\
\text { Abeliella riccioides } \\
\text { A. procera }\end{array}$ & $\begin{array}{l}\text { MLU.Mäg1937.IV.1 (L) } \\
\text { MLU.Mäg1937.IV.6 } \\
\text { MLU.Mäg1937.IV.8 } \\
\text { MLU.Mäg1937.IV. } 5 \text { (H) } \\
\text { (glass negative only) } \\
\text { MLU.Mäg1937.IV.10 (N) } \\
\text { MLU.Mäg1937.IV.2 (L+PL) } \\
\text { MLU.Mäg1937.IV.3 (S) } \\
\text { MLU.Mäg1937.IV.4 (H) } \\
\text { MLU.Mäg1937.IV.9 (H) } \\
\text { MLU.Mäg1937.IV.10 (H) } \\
\text { MLU.Mäg1937.V.1 (L+PL) } \\
\text { MLU.Mäg1937.V.2 (L+PL) }\end{array}$ & $\begin{array}{l}\text { Institut für Geowissenschaften } \\
\text { und Geographie, Halle, Germany }\end{array}$ & $\begin{array}{l}\text { loaned for } \\
\text { macrophotography, } \\
\text { microscopy and scans of } \\
\text { glass negatives }\end{array}$ \\
\hline Solle (1938) & $\begin{array}{l}\text { Olkenbachia hirsuta } \\
\text { O. pannosa } \\
\text { O. simplex } \\
\text { "Chondrites" symmetricus } \\
\text { "C." multifilum }\end{array}$ & $\begin{array}{l}\text { XXVI } 165 \text { a, d, e, f, i }(3 x) \\
\text { n }(4 x), \text { s }(3 x)(P) \\
\text { XXVI 166a (H) } \\
\text { XXVI 167a (H) } \\
\text { XXX 415a (H) } \\
\text { XXX 415b (P) } \\
\text { XXX 414b (P) }\end{array}$ & Senckenberg, Frankfurt, Germany & $\begin{array}{l}\text { photographed at } \\
\text { collection and/or loaned } \\
\text { for microscopy and } \\
\text { SEM }\end{array}$ \\
\hline Talent (1963) & Clionolithes sollei & $\mathrm{P} 60575(\mathrm{H}+\mathrm{P})$ & $\begin{array}{l}\text { Museum Victoria, Melbourne, } \\
\text { Australia }\end{array}$ & $\begin{array}{l}\text { series of images } \\
\text { provided by collection } \\
\text { manager }\end{array}$ \\
\hline
\end{tabular}


Table 1. Continued from previous page.

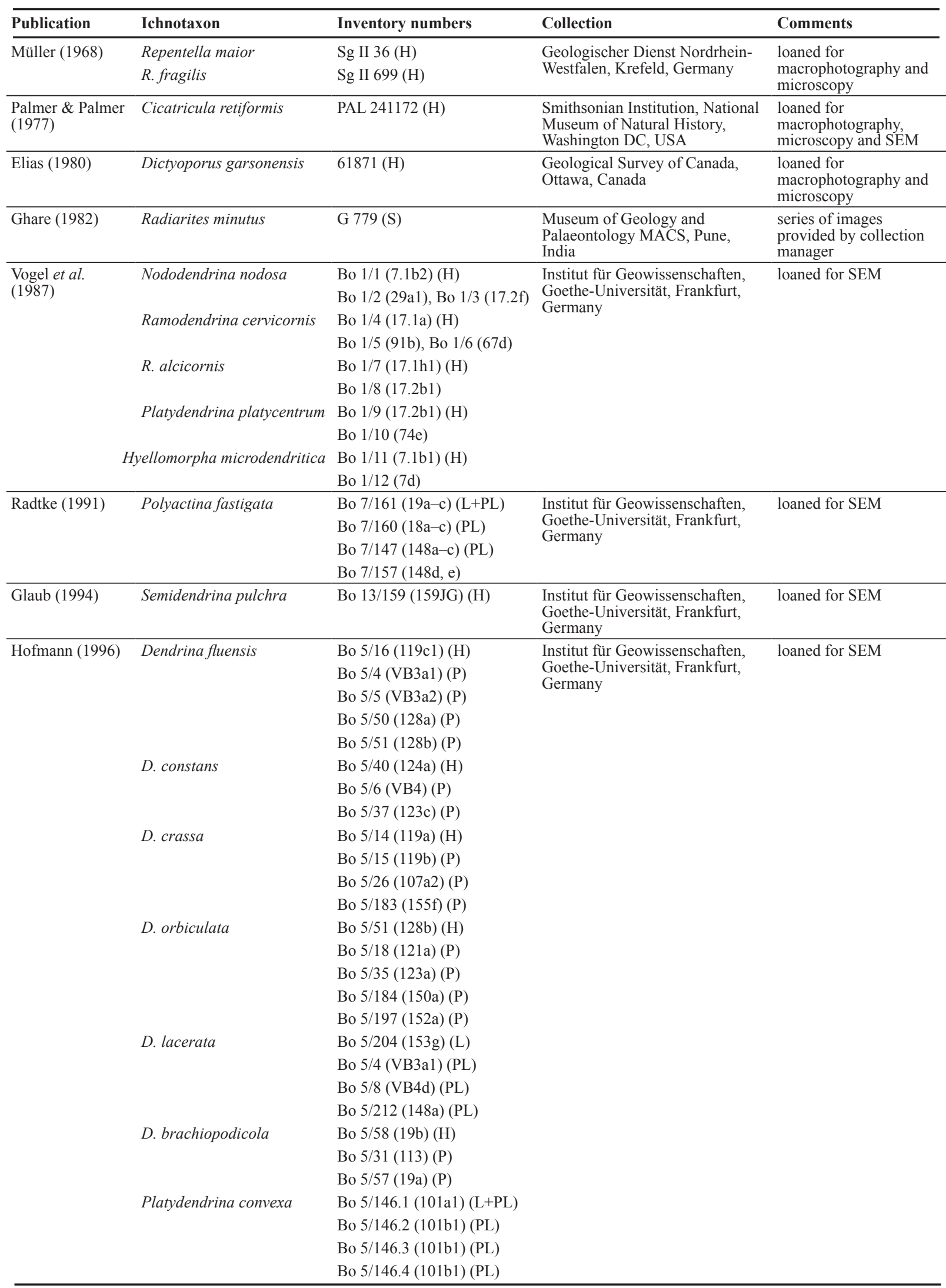




\section{Defining morphological characters as ichnotaxobases}

The ichnotaxonomy of dendrinid microborings can mainly be based on their various morphological features (Fig. 1), with size as a complementing character of subordinate value. In addition, the principle substrate type is considered of ichnotaxonomical relevance at the ichnogenus level and distinguishes, for instance, Abeliella (restricted to phosphatic fish scales or bones) from all other known dendrinids (found in calcareous skeletal substrates). Since descriptions of microborings are generally based on natural casts or resin casts, most morphological characters are herein addressed as though they were positives.

The first primary morphological expression and most important ichnotaxobase is the overall shape of the trace, which can be distinguished in round and roughly radial symmetrical traces, bilateral symmetrical traces, and boring systems or networks with an irregular outline. The central part of the trace is most commonly fused to form a larger chamber (horizontal node), or a globular initial chamber (vertical node) is developed, from which the rosetted part (plexus) of the trace emerges laterally. The second primary ichnogeneric ichnotaxobase is the vertical profile of the trace, i.e., the depth and type of penetration, separating prostrate (closely substrate parallel) traces from more dome-shaped dendrinids and deeply penetrating forms. If discernible, the type and number of apertures to the substrate surface (single point of entry, multiple apertures, one of which being the point of origin, or partly to completely roofless traces) is an additional morphological feature. However, since the number and shape of surface openings may be obliterated by even slight erosion or diagenetic processes such as pressure dissolution, and may additionally be influenced by organic surface shell layers such as the periostracum in molluscs, the value of this morphological character is sometimes limited. The orientation of the entrance tunnel (where present) is a related morphological character and can be oblique, vertical with lateral continuation or arcuate. A secondary ichnogeneric to primary ichnospecific ichnotaxobase is provided by the type of branching, distinguishing expanding, constant or tapering galleries, and the presence of anastomoses. A last morphological character of secondary ichnospecific relevance is the surface texture of the trace, which can be smooth, irregular, hairy or cuspate.

List of abbreviations (other abbreviations used in the tables are explained in the respective table captions):

$$
\begin{array}{ll}
\text { comb. nov. } & \text { new combination } \\
\text { ICZN } & =\text { International Code of Zoological Nomenclature } \\
\text { igen. nov. } & =\text { new ichnogenus } \\
\text { isp. nov. } & =\text { new ichnospecies } \\
\text { mean } & =\text { arithmetic mean value } \\
\mu \mathrm{CT} & =\text { micro-computed tomography } \\
\mathrm{n} & =\text { number of measurements or specimens } \\
\mathrm{n} / \mathrm{a} & =\text { not available/applicable } \\
\varnothing & =\text { diameter } \\
\mathrm{SD} & =\text { standard deviation } \\
\mathrm{SEM} & =\text { scanning electron microscopy/micrograph }
\end{array}
$$

Fig. 1 (page 7). Morphological characters of dendrinid microborings with respect to overall shape and symmetry of the trace, its vertical profile, openings to the substrate surface, orientation of entrance tunnel (where present), branching pattern and surface texture (in order of decreasing relevance as ichnotaxobase). 


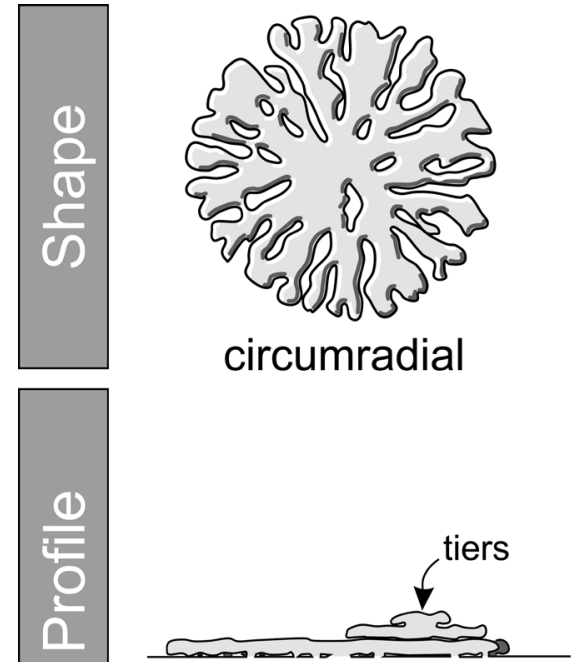

prostrate

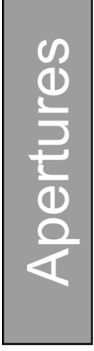

递

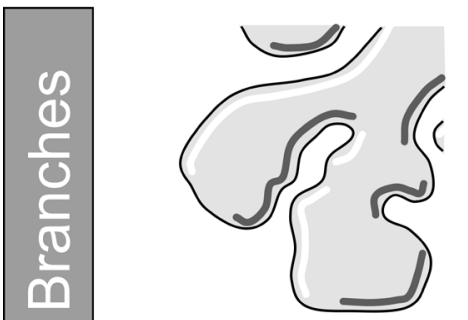

expanding

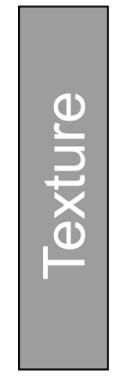

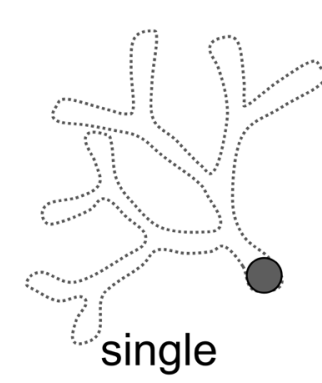

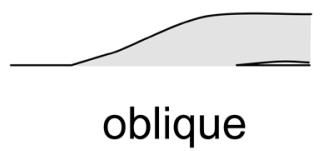

oblique

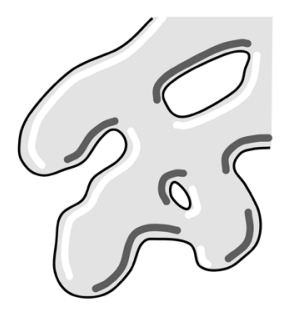

smooth

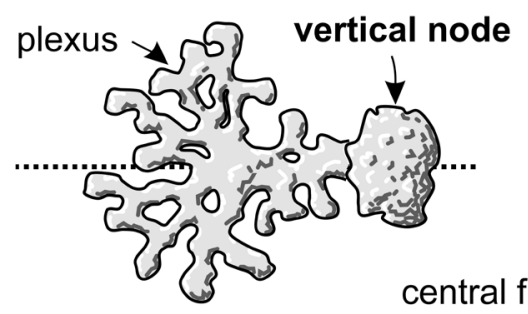

bilateral symmetry
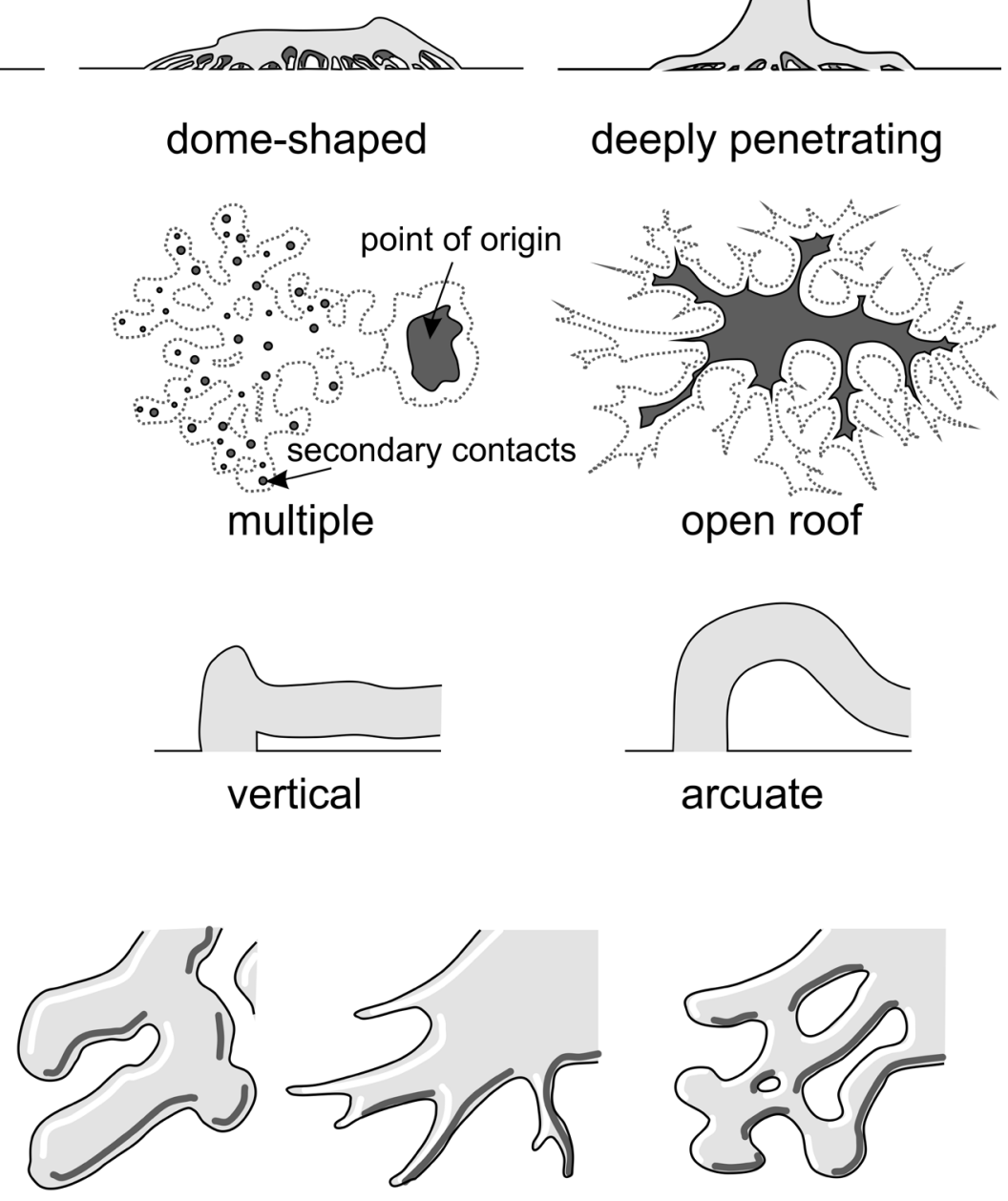

constant

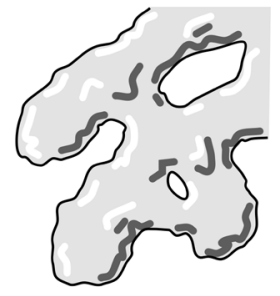

irregular

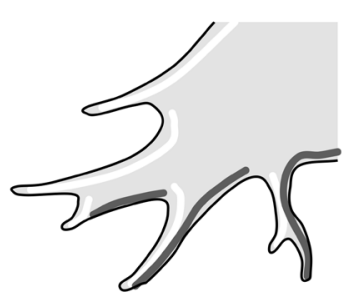

tapering

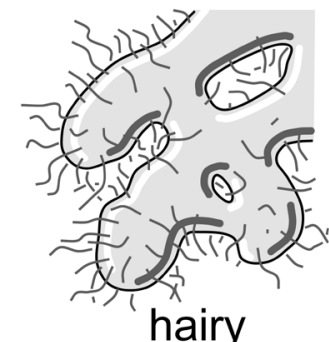

deeply penetrating

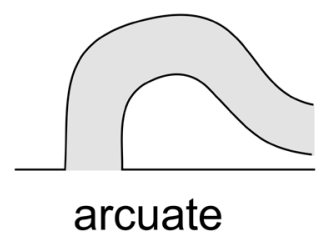

irregular
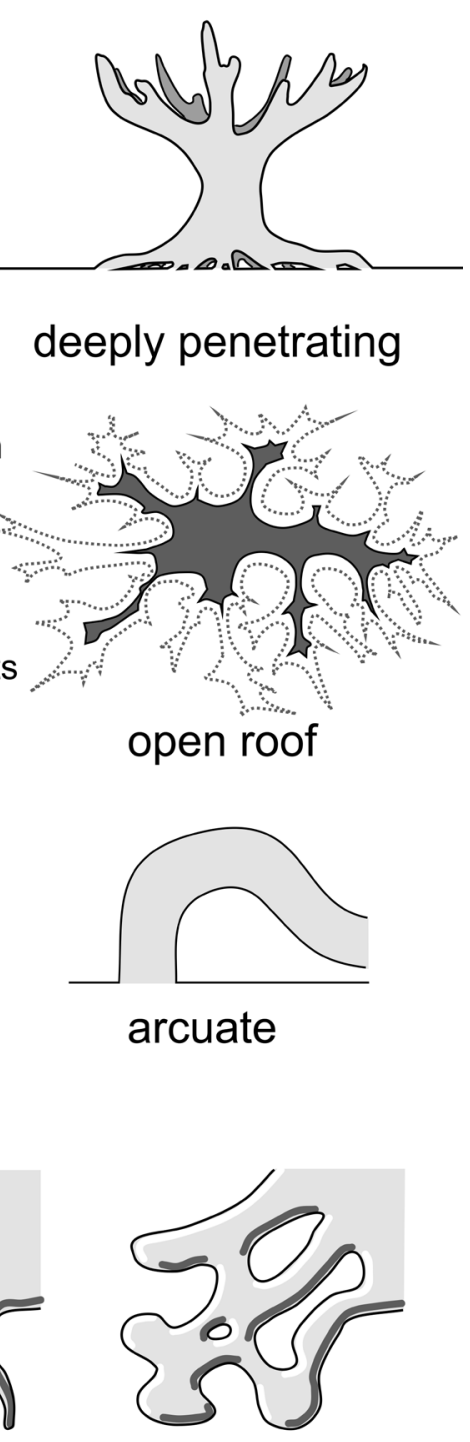

anastomosing

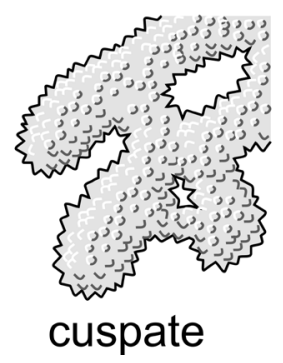




\section{Results}

\section{Inventory of dendrinid microborings}

The impressive number of ichnotaxa that has been proposed since the mid-nineteenth century for dendrinid microborings amounts to 84 ichnospecies, originally assigned to 25 different ichnogenera (Table 2). In the course of the present revision, this number was considerably condensed to only 22 ichnospecies included in 7 ichnogenera, complemented by 8 new ichnospecies and 2 new ichnogenera (Table 3 ). As a consequence of nomenclatural circumstances, and in order to achieve a practical set of morphologically distinct ichnogenera, a relatively large number of ten dendrinid ichnotaxa had to be re-grouped and are now addressed as new combinations. Investigation of new material and the reassessment of 63 dendrinid microborings previously listed in informal nomenclature (Table 4) allowed the establishment of two complementing ichnogenera and eight new ichnospecies. As a result, the majority of the known fossil dendrinid microborings can now be referred to suitable ichnotaxa, although a number of informal forms still require further investigation and proper ichnotaxonomical treatment, such as the 'FastigatdendrinaForm' recorded by Glaub (1994) and Bundschuh (2000), the 'Dendroid-Form 2' of Vogel \& Brett (2009) and 'Morphotype 4' in Seuss et al. (2015), just to name a few.

In the following account, a detailed review and revision of the systematic ichnology of dendrinid microborings is given, starting with a detailed list of synonyms. For better transparency concerning the ichnotaxonomical history of the various taxa, the original diagnoses are given (in cases of diagnoses other than in English, a translation is also provided), alongside the emended diagnosis as defined herein, taking into account earlier emendations where applicable. Likewise, the original description is provided (as a translation into English when applicable), complemented by a supplementary description where necessary. Morphological aspects that help distinguishing the various ichnotaxa (differential diagnosis) are included in the Remarks section, together with relevant facts about the history of research or other matters.

Table 2. Compilation of all ichnotaxa (in order of original ichnogenus and ichnospecies establishment) that have been proposed for dendrinid microborings, and the corresponding assignations and nomenclatural acts of the present revision. Continued on next two pages.

\begin{tabular}{|c|c|}
\hline Ichnotaxon & Ichnotaxonomical assessment / revision and status \\
\hline Cliona Grant, 1826 & $\rightarrow$ sponge biotaxon and no dendrinids, except for the following ichnotaxa \\
\hline C. paleodendrica Elias, 1957 & $=$ Nododendrina paleodendrica comb. nov. $\rightarrow$ valid \\
\hline C. stellata Elias, 1957 & $=$ inadequate illustration and holotype currently lost $\rightarrow$ nomen dubium \\
\hline C. fenestralis Elias, 1957 & $=$ junior synonym of Dictyoporus nodosus $\rightarrow$ rejected \\
\hline Talpina von Hagenow, 1840 & $\rightarrow$ no dendrinids, except for the following ichnotaxa \\
\hline T. sentiformis von Hagenow & $=$ Calcideletrix flexuosa but unpublished $\rightarrow$ nomen nudum $\rightarrow$ rejected \\
\hline T. foliacea von Hagenow & $=$ Dendrina belemniticola but unpublished $\rightarrow$ nomen nudum $\rightarrow$ rejected \\
\hline T. rotunda Müller, 1851 & $=$ without proper description or illustration $\rightarrow$ nomen dubium \\
\hline T. dendrina Morris, 1851 & $=$ Dendrina dendrina comb. nov. $=$ type ichnospecies of Dendrina $\rightarrow$ valid \\
\hline Dendrina Quenstedt, 1849 & $\rightarrow$ valid \\
\hline D. elongata Étallon, 1859 & $=$ without illustration and holotype currently lost $\rightarrow$ nomen dubium \\
\hline D. scoparia Étallon, 1859 & $=$ without illustration and holotype currently lost $\rightarrow$ nomen dubium \\
\hline D. stellata Étallon, 1859 & $=$ junior synonym of Dendrina dendrina comb. nov. $\rightarrow$ rejected \\
\hline D. lichenoidea Étallon, 1864 & $=$ without illustration and holotype currently lost $\rightarrow$ nomen dubium \\
\hline D. gracilis Étallon, 1864 & $=$ without illustration and holotype currently lost $\rightarrow$ nomen dubium \\
\hline D. punctata Étallon in Th. \& Ét., 1864 & $=$ inadequate illustration and holotype currently lost $\rightarrow$ nomen dubium \\
\hline
\end{tabular}


Table 2. Continued from previous page. Continued on next page.

\begin{tabular}{|c|c|}
\hline Ichnotaxon & Ichnotaxonomical assessment/revision and status \\
\hline D. fodicans Étallon in Th. \& Ét., 1864 & $=$ inadequate illustration and holotype currently lost $\rightarrow$ nomen dubium \\
\hline D. dumosa Étallon in Th. \& Ét., 1864 & $=$ inadequate illustration and holotype currently lost $\rightarrow$ nomen dubium \\
\hline D. ramulifera Étallon in Th. \& Ét., 1864 & $=$ inadequate illustration and holotype currently lost $\rightarrow$ nomen dubium \\
\hline D. europæa Fischer, 1875 & $=$ Nododendrina europaea comb. nov. (corrected spelling) $\rightarrow$ valid \\
\hline D. belemniticola Mägdefrau, 1937 & $\rightarrow$ valid \\
\hline D. anomala Mägdefrau, 1937 & $=$ Calcideletrix anomala comb. nov. $\rightarrow$ valid \\
\hline D. incomposita Mägdefrau, 1937 & $=$ Nododendrina incomposita comb. nov. $\rightarrow$ valid \\
\hline D. minor Mägdefrau, 1937 & $=$ junior synonym of Nododendrina incomposita comb. nov. $\rightarrow$ rejected \\
\hline D. crassa Hofmann, 1996 & $=$ junior synonym of Dendrina dendrina comb. nov. $\rightarrow$ rejected \\
\hline D. fluensis Hofmann, 1996 & $=$ junior synonym of Dendrina dendrina comb. nov. $\rightarrow$ rejected \\
\hline D. orbiculata Hofmann, 1996 & $=$ junior synonym of Dendrina belemniticola $\rightarrow$ rejected \\
\hline D. constans Hofmann, 1996 & $=$ junior synonym of Dendrina belemniticola $\rightarrow$ rejected \\
\hline D. lacerata Hofmann, 1996 & $\rightarrow$ valid \\
\hline D. brachiopodicola Hofmann, 1996 & $=$ junior synonym of Calcideletrix flexuosa $\rightarrow$ rejected \\
\hline D. ordoplana Plewes, 1996 & $=$ junior synonym of Dendrina dendrina in unpublished thesis $\rightarrow$ rejected \\
\hline Pyritonema McCoy, 1850 & $=$ hexactinellid sponge body fossils $\rightarrow$ no dendrinids \\
\hline P.? gigas Fritsch, 1908 & $=$ junior synonym of Clionolithes radicans $\rightarrow$ rejected \\
\hline Cobalia Étallon, 1859 & $=$ based on nomina dubia $\rightarrow$ nomen dubium \\
\hline C. jurensis Étallon, 1859 & $=$ without illustration and holotype currently lost $\rightarrow$ nomen dubium \\
\hline C. grayensis Étallon, 1964 & $=$ without illustration and holotype currently lost $\rightarrow$ nomen dubium \\
\hline Haguenowia Étallon, 1859 & $=$ based on nomina dubia $\rightarrow$ nomen dubium \\
\hline H. calloviensis Étallon, 1859 & $=$ without illustration and holotype currently lost $\rightarrow$ nomen dubium \\
\hline H. oxfordiensis Étallon, 1864 & $=$ without illustration and holotype currently lost $\rightarrow$ nomen dubium \\
\hline H. minima Étallon in Th. \& Ét., 1864 & $=$ inadequate illustration and holotype currently lost $\rightarrow$ nomen dubium \\
\hline H. kelloviana Étallon, 1864 & $=$ without illustration and holotype currently lost $\rightarrow$ nomen dubium \\
\hline Clionolithes Clarke, 1908 & $\rightarrow$ valid \\
\hline C. priscus (McCoy, 1855) & $=$ Palaeosabella prisca $\rightarrow$ not a dendrinid \\
\hline C. radicans Clarke, 1908 & $=$ type ichnospecies $\rightarrow$ valid \\
\hline C. reptans Clarke, 1908 & $=$ Filuroda reptans $\rightarrow$ not a dendrinid \\
\hline C. palmatus Clarke, 1908 & $\rightarrow$ valid \\
\hline C. hackberryensis (Thomas, 1911) & $=$ Talpina hackberryensis comb. nov. $\rightarrow$ not a dendrinid \\
\hline C. canna Price, 1916 & $=$ junior synonym of Talpina hackberryensis comb. nov. $\rightarrow$ rejected \\
\hline C. lizardensis Lees \& Thomas, 1918 & $=$ Talpina lizardensis comb. nov. $\rightarrow$ not a dendrinid \\
\hline C. quaerens Ruedemann, 1925 & $=$ unidentified tubular epilith $\rightarrow$ not a bioerosion trace \\
\hline C. fossiger Fenton \& Fenton 1932 & $=$ senior synonym of Arachnostega gastrochaenae $\rightarrow$ not a bioerosion trace \\
\hline C. irregularis Fenton \& Fenton 1932 & $=$ junior synonym of Talpina hackberryensis comb. nov. $\rightarrow$ rejected \\
\hline C. pricei Branson, 1937 & $=$ inadequate illustration and holotype currently lost $\rightarrow$ nomen dubium \\
\hline C. implicatus Hyde, 1953 & $=$ junior synonym of Palaeosabella prisca $\rightarrow$ rejected \\
\hline C. ramosus Hyde, 1953 & $=$ unidentified tubular boring with affinity to Talpina $\rightarrow$ not a dendrinid \\
\hline C. ? rectus Hyde, 1953 & $=$ Trifurcus (nomen nudum) rectus $\rightarrow$ not a dendrinid \\
\hline C. hunanensis Chow, 1957 & $=$ inadequate illustration and holotype currently lost $\rightarrow$ nomen dubium \\
\hline C. sollei Talent, 1963 & $=$ junior synonym of Clionolithes palmatus $\rightarrow$ rejected \\
\hline C. bullahirsuta Plewes, 1996 & $=$ in unpublished $\mathrm{PhD}$ Thesis $\rightarrow$ nomen nudum $\rightarrow$ rejected \\
\hline Calcideletrix Mägdefrau, 1937 & $\rightarrow$ valid \\
\hline C. flexuosa Mägdefrau, 1937 & $=$ type ichnospecies $\rightarrow$ valid \\
\hline C. breviramosa Mägdefrau, 1937 & $\rightarrow$ valid \\
\hline
\end{tabular}


Table 2. Continued from previous page.

\begin{tabular}{|c|c|}
\hline Ichnotaxon & Ichnotaxonomical assessment / revision and status \\
\hline Dictyoporus Mägdefrau, 1937 & $\rightarrow$ valid \\
\hline D. nodosus Mägdefrau, 1937 & $=$ type ichnospecies $\rightarrow$ valid \\
\hline D. garsonensis Elias, 1980 & $=$ junior synonym of Dictyoporus nodosus $\rightarrow$ rejected \\
\hline Abeliella Mägdefrau, 1937 & $\rightarrow$ valid \\
\hline A. riccioides Mägdefrau, 1937 & $=$ type ichnospecies $\rightarrow$ valid \\
\hline A. procera Mägdefrau, 1937 & $\rightarrow$ valid \\
\hline A. bellafurca Radtke et al., 2010 & $=$ Fascichnus bellafurcus comb. nov. (corrected spelling) $\rightarrow$ not a dendrinid \\
\hline Olkenbachia Solle, 1938 & $=$ junior synonym of Clionolithes $\rightarrow$ rejected \\
\hline O. hirsuta Solle, 1938 & $=$ junior synonym of Clionolithes radicans $\rightarrow$ rejected \\
\hline O. pannosa Solle, 1938 & $=$ Clionolithes pannosus comb. nov. (corrected spelling) $\rightarrow$ valid \\
\hline O. simplex Solle, 1938 & $=$ poorly preserved Clionolithes radicans $\rightarrow$ rejected \\
\hline “Chondrites" Solle, 1938 & $=$ provisional ichnogenus assignation only $\rightarrow$ rejected \\
\hline “C.” symmetricus Solle, 1938 & $=$ cf. Clionolithes cervicornis and brachiopod muscle scar $\rightarrow$ rejected \\
\hline “C.” multifilum Solle, 1938 & $=$ mould of bryozoan or mineralisation and not a bioerosion trace $\rightarrow$ rejected \\
\hline Repentella Müller, 1968 & $=$ moulds of epiliths $=$ not a trace fossil $\rightarrow$ rejected \\
\hline R. maior Müller, 1968 & $=$ mould of an epilith $=$ not a trace fossil $\rightarrow$ rejected \\
\hline R. fragilis Müller, 1968 & $=$ mould of an epilith $=$ not a trace fossil $\rightarrow$ rejected \\
\hline Cicatricula Palmer \& Palmer, 1977 & $=$ junior synonym of Dictyoporus $\rightarrow$ rejected \\
\hline C. retiformis Palmer \& Palmer, 1977 & $=$ junior synonym of Dictyoporus nodosus $\rightarrow$ rejected \\
\hline Radiarites Ghare, 1982 & $=$ diagenetic reduction halos $\rightarrow$ not a fossil $\rightarrow$ nomen nudum $\rightarrow$ rejected \\
\hline R. minutus Ghare, 1982 & $=$ diagenetic reduction halos $\rightarrow$ not a fossil $\rightarrow$ nomen nudum $\rightarrow$ rejected \\
\hline Platydendrina Vogel et al., 1987 & $=$ junior synonym of Clionolithes $\rightarrow$ rejected \\
\hline P. platycentrum Vogel et al., 1987 & $=$ junior synonym of Clionolithes pannosus comb. nov. $\rightarrow$ rejected \\
\hline P. convexa Hofmann, 1996 & $=$ Clionolithes convexus comb. nov. $($ corrected spelling) $\rightarrow$ valid \\
\hline Ramodendrina Vogel et al., 1987 & $=$ junior synonym of Clionolithes $\rightarrow$ rejected \\
\hline R. cervicornis Vogel et al., 1987 & $=$ Clionolithes cervicornis $\rightarrow$ valid \\
\hline R. alcicornis Vogel et al., 1987 & $=$ Clionolithes alcicornis comb. nov. $\rightarrow$ valid \\
\hline Nododendrina Vogel et al., 1987 & $\rightarrow$ valid \\
\hline N. nodosa Vogel et al., 1987 & $=$ type ichnospecies $\rightarrow$ valid \\
\hline Hyellomorpha Vogel et al., 1987 & $=$ junior synonym of Nododendrina $\rightarrow$ rejected \\
\hline H. microdendritica Vogel et al., 1987 & $=$ junior synonym of Nododendrina incomposita comb. nov. $\rightarrow$ rejected \\
\hline H. acuminata Tavernier \& Golubic, 1993 & $=$ junior synonym of Nododendrina europaea comb. nov. $\rightarrow$ rejected \\
\hline H. magna Tavernier \& Golubic, 1993 & $=?$ Nododendrina europaea comb. nov. or $?$ Fascichnus grandis $\rightarrow$ rejected \\
\hline H. cheimadendritica Plewes, 1996 & $=$ junior synonym of Nododendrina nodosa in unpublished thesis $\rightarrow$ rejected \\
\hline Polyactina Radtke, 1991 & $\rightarrow$ no dendrinids, except for the following taxon \\
\hline P. fastigata Radtke, 1991 & $=$ Calcideletrix fastigata comb. nov. $\rightarrow$ valid \\
\hline Dendrorete Tavernier et al., 1992 & $=$ junior synonym of Dictyoporus $\rightarrow$ rejected \\
\hline D. balani Tavernier et al., 1992 & $=$ Dictyoporus balani comb. nov. $\rightarrow$ valid \\
\hline Globodendrina Plewes et al., 1993 & $=$ foraminiferan body fossil (producer of $N$. europaea) $\rightarrow$ not a dendrinid \\
\hline G. monile Plewes et al., 1993 & $=$ foraminiferan body fossil (producer of $N$. europaea) $\rightarrow$ not a dendrinid \\
\hline Granarborus Plewes, 1996 & $=$ in unpublished $\mathrm{PhD}$ thesis $\rightarrow$ nomen nudum $\rightarrow$ rejected \\
\hline G. teicherti Plewes, 1996 & $=$ in unpublished $\mathrm{PhD}$ thesis $\rightarrow$ nomen nudum $\rightarrow$ rejected \\
\hline G. nervosus Plewes, 1996 & $=$ in unpublished $\mathrm{PhD}$ thesis $\rightarrow$ nomen nudum $\rightarrow$ rejected \\
\hline Semidendrina Bromley et al., 2007 & $=$ junior synonym of Nododendrina $\rightarrow$ rejected \\
\hline S. pulchra Bromley et al., 2007 & $=$ junior synonym of Nododendrina europaea comb. nov. $\rightarrow$ rejected \\
\hline Pyrodendrina Tapanila, 2008 & $\rightarrow$ valid \\
\hline P. cupra Tapanila, 2008 & $=$ type ichnospecies $\rightarrow$ valid \\
\hline
\end{tabular}


Table 3. Revised suite of ichnotaxa (in order of original ichnogenus and ichnospecies establishment; type ichnospecies marked by asterisk) comprised within the ichnofamily Dendrinidae, and the most relevant diagnostic ichnogeneric feature(s).

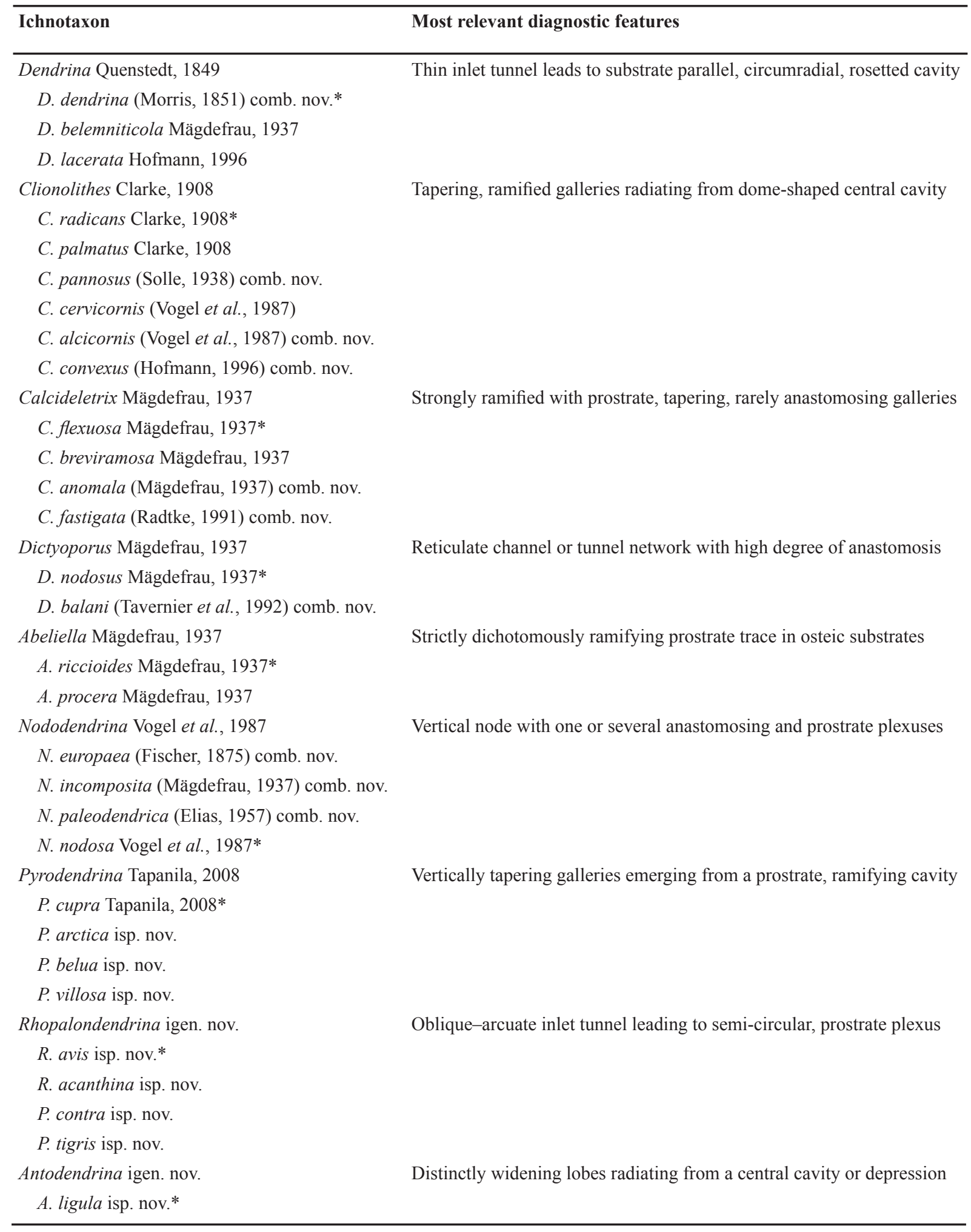


Table 4. Compilation of informally named records of dendrinid microborings (in order of publication), together with the identifications based on the revised dendrinid ichnotaxonomy. ? = uncertain; $\mathrm{p}=$ partim. Continued on next page.

\begin{tabular}{|c|c|c|}
\hline Informal name & Publication & Identification \\
\hline Spinate Microborings & Edwards \& Perkins (1974) & ? Rhopalondendrina contra isp. nov. \\
\hline Spinate boring form & Zeff \& Perkins (1979) & ? Rhopalondendrina acanthina isp. nov. \\
\hline Algal form B & Budd \& Perkins (1980) & ? Calcideletrix fastigata comb. nov. \\
\hline Sponge form $\mathrm{B}$ & Budd \& Perkins (1980) & ? Rhopalondendrina acanthina isp. nov. \\
\hline Morfotipo $\mathrm{B}_{2}$ & Mayoral (1988) & ? Calcideletrix fastigata comb. nov. \\
\hline Morfotipo $\mathrm{B}_{3}$ & Mayoral (1988) & ? Calcideletrix fastigata comb. nov. \\
\hline Morfotipo $\mathrm{B}_{4}$ & Mayoral (1988) & ? Pyrodendrina villosa isp. nov. \\
\hline Morfotipo $\mathrm{B}_{5}$ & Mayoral (1988) & $=$ Nododendrina europaea comb. nov. \\
\hline J-Form C-1 & Glaub (1988) & $=$ Nododendrina europaea comb. nov. \\
\hline J-Form C-2 & Glaub (1988) & ? Entobia isp. \\
\hline J-Form F-4 & Glaub (1988) & $=$ Rhopalondendrina avis isp. nov. \\
\hline Sponge, Form 1 & Günther (1990) & $=$ Rhopalondendrina tigris isp. nov. \\
\hline Rosetten-Form B & Hofmann \& Vogel (1992) & $=$ Calcideletrix anomala comb. nov. \\
\hline Rosetten-Form D & Hofmann \& Vogel (1992) & $=$ Dendrina belemniticola \\
\hline Rosetten-Form E & Hofmann \& Vogel (1992) & $=$ Dendrina belemniticola \\
\hline Rosetten-Form G & Hofmann \& Vogel (1992) & $=$ Calcideletrix flexuosa \\
\hline Dendroid-Form I & Schmidt (1992) & ? Entobia isp. \\
\hline Dendroid-Form II & Schmidt (1992) & ? Clionolithes radicans \\
\hline Dendroid-Form III & Schmidt (1992) & ? Rhopalondendrina acanthina isp. nov. \\
\hline Echinoid form & Radtke (1993) & $=$ Rhopalondendrina tigris isp. nov. \\
\hline Cliona sp. 1 & Schmidt \& Freiwald (1993) & $=$ Nododendrina europaea comb. nov. \\
\hline Semidendrina-Form & Glaub (1994) & $=$ Nododendrina europaea comb. nov. \\
\hline Fastigatdendrina-Form & Glaub (1994) & $?$ \\
\hline Rhopalondendrina-Form & Glaub (1994) & $=$ Rhopalondendrina avis isp. nov. \\
\hline Entobia-Form 2 & Glaub (1994) & $?$ \\
\hline J-Form C-2 & Glaub \& Schmidt (1994) & ? Entobia isp. \\
\hline Dendroid-Form II & Glaub \& Schmidt (1994) & ? Clionolithes radicans \\
\hline Dendroid-Form III & Glaub \& Schmidt (1994) & ? Rhopalondendrina acanthina isp. nov. \\
\hline Rosetten-Form & Glaub \& Schmidt (1994) & $?$ \\
\hline Rosetten-Form A & Hofmann (1996) & ? (p) Dendrina dendrina \\
\hline Fastigatdendrina-Form & Bundschuh (2000) & $?$ \\
\hline Dendroid-Form A & Bundschuh (2000) & $=$ Dictyoporus nodosus \\
\hline Dendroid-Form B & Bundschuh (2000) & ? Clionolithes radicans \\
\hline Dendroid-Form C & Bundschuh (2000) & $=$ Dictyoporus nodosus \\
\hline Dendroid-Form D & Bundschuh (2000) & $?$ \\
\hline Piatella-Form & Bundschuh (2000) & ? Dendrina lacerata \\
\hline Rhopalodendrina form & Vogel \& Marincovich (2004) & ? Rhopalondendrina avis isp. nov. \\
\hline Echinoid Form & Glaub (2004) & $=$ Rhopalondendrina tigris isp. nov. \\
\hline Semidendrina Form & Beuck \& Freiwald (2005) & $=$ Nododendrina europaea comb. nov. \\
\hline Foraminiferan trace & Försterra et al. (2005) & $=$ Pyrodendrina villosa isp. nov. \\
\hline Rosette A & Tapanila (2005) & $=$ Pyrodendrina cupra \\
\hline Semidendrina-form & Bromley (2005) & $=$ Nododendrina europaea comb. nov. \\
\hline Non-camerate radiating form & Bromley (2005) & $=$ Pyrodendrina villosa isp. nov. \\
\hline Hirsute camerate form & Bromley (2005) & ? Pyrodendrina villosa isp. nov. \\
\hline Semidendrina Form & Wisshak et al. (2005a) & $=$ Pyrodendrina villosa isp. nov. \\
\hline Semidendrina-form & Wisshak et al. (2005b) & $=$ Nododendrina europaea comb. nov. \\
\hline Sponge form II & Wisshak et al. (2005a) & $=$ Pyrodendrina villosa isp. nov. \\
\hline Sponge form VI & Wisshak et al. (2005a) & ? Pyrodendrina arctica isp. nov. \\
\hline Rosette-shaped borings & Botquelen \& Mayoral (2005) & ? Clionolithes radicans \\
\hline
\end{tabular}


Table 4. Continued from previous page.

\begin{tabular}{|c|c|c|}
\hline Informal name & Publication & Identification \\
\hline Semidendrina-form & Wisshak (2006) & $=(\mathrm{p})$ Nododendrina europaea comb. nov. \\
\hline Microsponge-form 2 & Wisshak (2006) & $=$ Pyrodendrina villosa isp. nov. \\
\hline Microsponge-form 6 & Wisshak (2006) & ? Pyrodendrina arctica isp. nov. \\
\hline Semidendrina-form & Wisshak \& Rüggeberg (2006) & $=$ Nododendrina europaea comb. nov. \\
\hline Semidendrina-form & Santos \& Mayoral (2008) & $=$ Nododendrina europaea comb. nov. \\
\hline Semidendrina-form & Pereira et al. (2009) & ? Nododendrina europaea comb. nov. \\
\hline Dendroid Form 1 & Vogel \& Brett (2009) & ? Clionolithes cervicornis \\
\hline Dendroid Form 2 & Vogel \& Brett (2009) & $?$ \\
\hline Mini-Meander Form & Vogel \& Brett (2009) & $?$ \\
\hline Foraminiferan Form & Beuck et al. (2010) & $=(\mathrm{p})$ Pyrodendrina villosa isp. nov. \\
\hline Bunched whips form & Wisshak et al. (2011) & $?$ \\
\hline Dendroid form 1 & Wisshak et al. (2011) & $?$ \\
\hline Dendroid form 2 & Wisshak et al. (2011) & $=$ Rhopalondendrina acanthina isp. nov. \\
\hline Morphotype 4 & Seuss et al. (2015) & $?$ \\
\hline
\end{tabular}

Dendrinidae Bromley, Wisshak, Glaub \& Botquelen, 2007

\section{Type ichnogenus}

Dendrina Quenstedt, 1849 by subsequent designation (herein).

\section{Original diagnosis}

Microborings having a rosetted or incompletely rosetted (i.e., fan-shaped) morphology, with or without a central or marginal main chamber.

\section{Included ichnogenera}

Dendrina Quenstedt, 1849; Clionolithes Clarke, 1908; Calcideletrix Mägdefrau, 1937; Dictyoporus Mägdefrau, 1937; Abeliella Mägdefrau, 1937; Nododendrina Vogel et al., 1987; Pyrodendrina Tapanila, 2008; Rhopalondendrina igen. nov. and Antodendrina igen. nov.

\section{Remarks}

Bromley et al. (2007) established the ichnofamily Dendrinidae by providing an ichnofamily diagnosis and a list of included ichnogenera. A type ichnogenus, however, was not specified, albeit implied by the chosen family-group name. In order to fulfil the requirements of the Code (ICZN 1999: Art. 29 and 63), the oldest and eponymous ichnogenus Dendrina Quenstedt, 1849, is herein specified as type ichnogenus.

Confinement of the morphological range addressed by the dendrinids is given by the lack of cameration (separating it from Entobia), the lack of sack-shaped components (separating it from Saccomorpha and Rhopalia), and the common presence of anastomoses (distinguishing it from Rhopalia and Fascichnus). The closest morphological overlap concerns the entobians Entobia megastoma (Fischer, 1868) and E. dendritica Pleydell \& Jones, 1988, which are both only vaguely camerate and have a dendritic branching pattern similar to that of Clionolithes, but are much larger. Since the entobians, and possibly some of the ichnospecies of Clionolithes, are produced by excavating sponges, they partly share the feature of a cuspate microtexture produced by individual etching cells. 
Dendrina Quenstedt, 1849

\section{Type ichnospecies}

Talpina dendrina Morris, 1851 (now Dendrina dendrina (Morris, 1851) comb. nov.) by subsequent designation by Häntzschel (1962).

\section{Original diagnosis}

$\mathrm{n} / \mathrm{a}$

\section{Emended diagnosis}

Rosetted boring system, developed closely parallel to surface of calcareous skeletal substrates, with a circular to irregular outline, originating from a single point at the end of a tubular inlet tunnel. Individual galleries vary in width at constant height, ramify and may anastomose or fuse to form a flat central cavity. Fine galleries connect the rosette with the substrate surface, preferentially towards the rounded distal terminations.

\section{Original description}

The other group, one may call it Dendrina [...], based on its dendritic ramifications, is even more enigmatic, since an entrance can certainly not be found. They are not quite tubes, but merely flattened ramifications, located closely below the surface, not rarely penetrated by Talpinians, and here and there unroofed, in the latter case leaving a rough shallow depression. The figured specimen [...] stems from the chalk of Antrim, and shows circular, more ramified, as well as unspecified patchy individuals. [Translated from German]

\section{Remarks}

Friedrich von Hagenow (1840) was the first who tackled the conspicuous bioerosion trace fossils in the Upper Cretaceous belemnite rostra from the Isle of Rügen, Germany, by establishing the ichnogenus Talpina with two ichnospecies, T. ramosa and T. solitaria. He also recognised the two most common dendrinids and named them T. foliacea and T. sentiformis. Unfortunately, it appears that he never formally published and figured these two latter ichnospecies, rendering them nomina nuda (Wisshak et al. 2017). The two names only made their way into the literature via citation as "in litt." (= personal communication) in Geinitz (1849: 108-109) and by indirect reference in Müller (1851: 59-60). Recently, Wisshak et al. (2017) rediscovered syntypes of all four of von Hagenow's Talpina ichnospecies in collections of the Museum für Naturkunde Berlin and the Naturhistorische Sammlungen Dresden (both Germany), allowing identification of T. foliacea as Dendrina belemniticola and T. sentiformis as Calcideletrix flexuosa, both formally established by Mägdefrau (1937).

The first description and illustrations of Dendrina were provided by Quenstedt (1849: pl. 30, figs 3637) whose figures show one belemnite guard (Belemnites mucronatus Schlotheim, 1813) with multiple bioerosion traces specified as Talpina ramosa and Dendrina (Figs 2A, 3A), and another belemnite with T. pungens Quenstedt, 1849, T. solitaria and T. ramosa. The traces are not labelled, thus complicating a correct assignation. Both figures show two morphotypes of dendrinids, the forms later considered by Morris (1851) to be Talpina dendrina and by Mägdefrau (1937) as Dendrina belemniticola (see below). Decades later, Quenstedt (1885: pl. 39, fig. 39) figured another belemnite rostrum (Terebella) with T. pungens, T. solitaria and T. ramosa, as well as Dendrina, this time being clearly labelled (Figs 2B, 3B). The trace labelled as Dendrina is reminiscent of T. dendrina in Morris (1851: pl. IV, figs 6b, 7) (Fig. 2D-I), whereas the trace corresponding to D. belemniticola in Mägdefrau (1937: pl. IV, figs 1, 6, 8) (Fig. 3D) in turn was not labelled by Quenstedt, albeit interpreted as such by subsequent workers (Nadjin 1969; Voigt 1972; Nestler 1975). The provenance of Quenstedt's belemnites (Quenstedt 1849) is dubious, and according to the discussion in Voigt (1972) probably neither Antrim (N Ireland), as stated in the figure legend of one of the specimens (Quenstedt 1849: fig. 36) as well as in the original description 
(see above) and on the label of the material that used to be reposited in the Tübingen collection, nor Rügen (Germany), as stated in the figure explanation of the other specimen (Quenstedt 1849: fig. 37). Instead, it probably originates from some other chalk outcrop, possibly in England. Equally uncertain, but according to Voigt (1972) most likely, is the question of whether or not the original belemnite (Voigt 1972: pl. 2, figs 2-3) is the specimen depicted - with some artistic freedom - by Quenstedt (1849: pl. 30, fig. 37). Both Voigt (1972: pl. 1-2) and Plewes (1996: pl. 22) reinvestigated the original Quenstedt material and provided close-up photographs of the various Dendrina and Talpina specimens (Figs 2C, 3C). Despite an extensive query for the original material in the collections in Tübingen, Munich, Berlin, Frankfurt, Hamburg, London and Aberystwyth (Plewes' affiliation in 1996, where the specimens were studied last), the whereabouts of the Quenstedt material could not be tracked down and the material has to be regarded currently as lost. Quenstedt neither designated a type ichnospecies, nor provided a diagnosis, both not legal requirements for taxa established prior to 1931 (ICZN 1999). Morris (1851: 87, pl. IV, figs $6 \mathrm{~b}, 7)$ consequently adopted Quenstedt's ichnogenus name as a new ichnospecies name under the ichnogenus Talpina von Hagenow, 1840, thereby addressing it as "Talpina dendrina Quenstedt". Based on the practical monotypy of this first nominal species referred to Quenstedt's bare genus, and by principle of virtual tautonymy, $D$. dendrina is the type ichnospecies of Dendrina, as previously specified by Häntzschel (1962). However, according to Treatise format, it was therein given in its original ichnogenus combination as Talpina dendrina Morris, 1851 and its assignment as Dendrina dendrina (Morris, 1851) is hereby formally introduced as a new combination.

A related ichnotaxon and potential nomen oblitum (never addressed after 1899) is Talpina rotunda, mentioned without proper description or illustration by Müller (1851: 60) as having a circular shape. However, this very vague morphological description applies to many traces in Cretaceous belemnites and thus does not provide reasonable grounds to seriously consider it a senior synonym of Dendrina belemniticola or D. lacerata, both traces with a quite circular outline. Without a clearly established synonymy, however, it cannot be considered a nomen oblitum either, since this nomenclatural act would require naming a nomen protectum, hence leaving T. rotunda in the nimbus of a nomen dubium.

Between 1859 and 1864, Étallon (Étallon 1859a, 1859b, 1864; Thurmann \& Étallon 1864) established a total of nine ichnospecies of Dendrina, none of which was adopted by subsequent workers. This is because all of Étallon's ichnospecies were based on rudimentary descriptions only and with or without only an inadequate illustration. Hence, they have to be regarded as nomina dubia. One of these ichnospecies, i.e., D. elongata, Étallon himself (Étallon 1959b) assigned to Talpina, and another, i.e., $D$. stellata, he synonymised with $D$. dendrina. Likewise of dubious status are the related ichnogenera Cobalia (comprising two ichnospecies) and Haguenowia (four ichnospecies) described by Étallon (1859a), both also entirely based on nomina dubia. In an attempt to locate the original type material, the collections in Paris, Lyon, Gray, Porrentruy, Bern and Basel were consulted, apparently none of which houses the material in question, which thus needs to be considered as currently lost. Considering these circumstances, unfortunately there appears no feasible way forward but to regard Étallon's dendrinids as nomina dubia, altogether.

The first extant relatives of Dendrina were observed in bivalve shells from the Golfe de Gascogne off the French coast and elsewhere by Fischer (1875), who established the ichnotaxon Dendrina europcea. This dendrinian is herein classified within Nododendrina as N. europaea comb. nov.

Mägdefrau (1937), in his important review on endolithic bioerosion traces 'Lebensspuren fossiler 'Bohr' -Organismen", established four ichnospecies of Dendrina, including the widely used D. belemniticola, thereby finally formalising the second original Quenstedt (1849) dendrinian (see above). The very small D. incomposita is herein addressed as Nododendrina incomposita comb. nov., and Mägdefrau's D. minor is synonymised with it. Dendrina anomala is considered a new combination under Calcideletrix, another one of Mägdefrau's (1937) ichnogenera. 
Based on an SEM analysis of epoxy-resin casts, Hofmann (1996) refined the diagnosis of Dendrina and, following a splitter approach, disregarded $D$. dendrina and $D$. belemniticola while establishing a series of morphologically very similar new ichnospecies of Dendrina. Most of these are herein considered as a reflection of the ontogeny and the morphological variability of the former two ichnospecies and thus as their junior synonyms. Another one of Hofmann's dendrinids, i.e., D. brachiopodicola, is herein synonymised with Calcideletrix flexuosa Mägdefrau, 1937. In the same year, Plewes (1996) attempted to establish $D$. ordoplana, which is, however, also morphologically reminiscent of $D$. dendrina, and apart from that was never formally published, creating a nomen nudum.

In conclusion, among the 22 ichnospecies originally erected under the umbrella of the ichnogenus Dendrina, merely three of them remain nomenclaturally robust and morphologically sufficiently distinctive (i.e., their geometry cannot be explained by ontogenetic stages of the same ichnospecies or by differences in the substrate) to be considered ichnotaxonomically distinct and valid. These are D. dendrina (Morris, 1851), D. belemniticola Mägdefrau, 1937 and D. lacerata Hofmann, 1996. Two further original ichnospecies of Dendrina are now grouped within Calcideletrix and Nododendrina (see above). Dendrina is distinguished from all other Dendrinidae by its tubular inlet tunnel, leading to the centre of a radiating rosette of constant thickness and with peripheral branches not tapering to fine terminations.

An invalid junior homonym, Dendrina Costa in Fornasini, 1898, was established for a foraminiferan. No substitute name was proposed and, according to Loeblich \& Tappan (1964), the genus is presently considered synonymous with Cibicidoides Thalmann, 1939. In the botanical nomenclature, Dendrina was established by Fries (1832) as a valid homonym with two species (D. flava and D. pulla) of ascomycete fungi.

Dendrina dendrina (Morris, 1851) comb. nov.

Fig. 2

Talpina dendrina Morris, 1851: 87, pl. IV, figs 6b, 7.

Dendrina crassa Hofmann, 1996: 70, pl. 5, figs 1-4.

Dendrina fluensis Hofmann, 1996: 72, pl. 6, figs 3-6.

Dendrina lacerata Hofmann, 1996 (partim): 78, pl. 8, figs 5-6.

Dendrina - Quenstedt 1849 (partim): 470, pl. 30, figs 36 (upper three dendrinids), 37 (upper two dendrinids); 1885 (partim): 496, pl. 38, fig. 39 (individuals labelled “d"). — Radwański 1972 (partim): 257, figs 1-4. — Hillmer \& Schulz 1973 (partim): pl. 1, figs 1-2. — Whittlesea 2005 (partim): 18, figs 1,3 .

Without name - Dacqué 1921 (partim): 457, fig. 214 (reproduced from Quenstedt 1849). — Gravesen \& Jakobsen 2011: 77, fig. 8.

Talpina dendrina - Voigt 1929: 122, pl. IV, figs 9-10.

Dendrina belemniticola - Mägdefrau 1937 (partim): 55, pl. IV, figs 1 (bottom individual), 6, 8. Häntzschel 1962 (partim): W230, fig. 144-2 (reproduced from Mägdefrau 1937); 1975 (partim): W127, fig. 78-7 (reproduced from Mägdefrau 1937). - Pugaczewska 1965: pl. 1, fig. 2. Nadjin 1969 (partim): 138, fig. 53 (reproduced from Quenstedt 1849), pl. III, fig. 7, pl. IV, figs 1 (bottom trace), 6, 8 (reproduced from Mägdefrau 1937). — Voigt 1972 (partim): 95, pl. 1, figs 3a-c (reproduced from Quenstedt 1849), pl. 2, figs 1c, 2-3c, 6d (fig. 1d reproduced from Quenstedt 1849, fig. 4 reproduced from Quenstedt 1885). - Kutscher 1972 (partim): 27, figs 3-5. - Nestler 1975 (partim): 108, fig. 159b reproduced from Quenstedt 1849). - Schnick 1992 (partim): 112, pl. 3, fig. 4, pl. 4, fig. 5. — Girod \& Rösner 2013 (partim): 280, fig. 12. — Rudolph 2014 (partim): 18, fig. 23.

Rosetten-Form A - Hofmann 1996: (partim; ?) 83, pl. 10, fig. 3.

Dendrina ordoplana - Plewes 1996: 166, pl. 22, figs 5-8, pl. 23, figs 1-7.

?Dendrina belemniticola - Hoşgör \& Košt'ák 2012: 38, fig. 4I. 

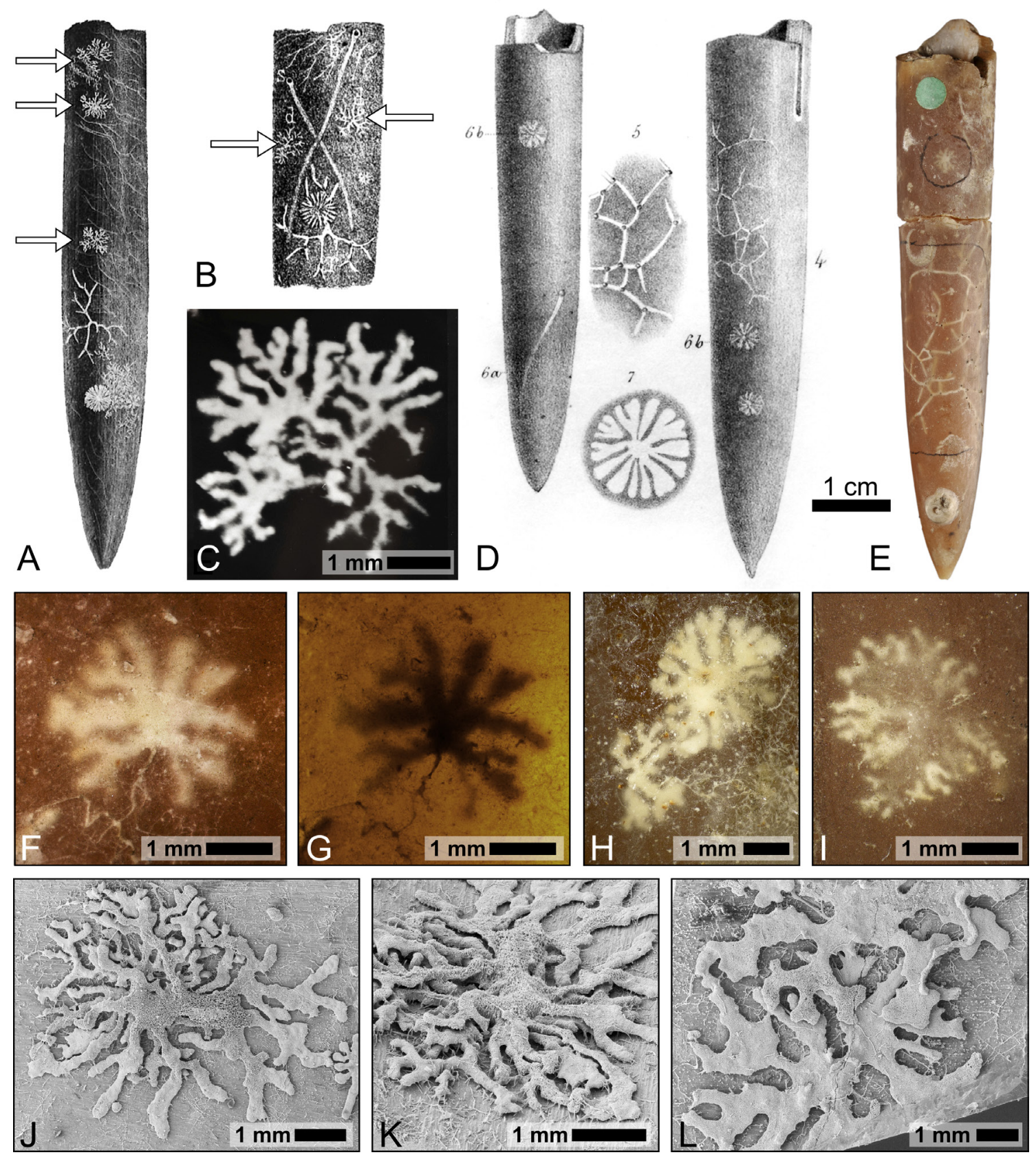

Fig. 2. Dendrina dendrina (Morris, 1851) comb. nov. A. Original illustration of belemnite with various traces, including $D$. dendrina (arrows; reproduced from Quenstedt 1849: pl. 30, fig. 36); provenance unresolved. B. Original amalgam, including D. dendrina (arrows and label "d"; reproduced from Quenstedt 1885: pl. 38, fig. 39). C. Re-illustration of original Quenstedt Dendrina (reproduced from Plewes 1996: pl. 22, fig. 5). D. Original illustrations of Talpina dendrina (=D. dendrina; reproduced from Morris 1851: pl. IV, figs 4-7; $5=$ Talpina ramosa; $6 \mathrm{a}=$ Trypanites solitarius). E. Morris' original belemnite from the Upper Cretaceous of Norfolk, UK, including the lectotype of $D$. dendrina (encircled). F-G. Close-up of lectotype under incipient and transparent light; the inlet canal is clearly visible. $\mathbf{H}-\mathbf{I}$. Three paralectotypes in the same belemnite. J-K. Planar and oblique views of the holotype of junior synonym D. fluensis Hofmann, 1996, illustrating the typical multi-tier occurrence, irregular branching, and meandering galleries; SEM of epoxy cast of a belemnite from the lower Maastrichtian at Kronsmoor, Germany. L. Holotype of junior synonym D. crassa Hofmann, 1996, within the morphological range of D. dendrina; SEM of epoxy cast of a belemnite from the lower Maastrichtian at Kronsmoor, Germany. 


\section{Original diagnosis}

$\mathrm{n} / \mathrm{a}$

\section{Emended diagnosis}

Rosette of irregular to sub-circular outline, with loosely spaced galleries radiating from the centre in meandering fashion, ramifying with widened bi- and trifurcations of various angles, only rarely forming anastomoses. In larger individuals, additional tiers may develop.

\section{Original description}

This form has a very dendritic appearance, the branches are compressed, closely aggregated, generally arising from a common centre, and diverging in a somewhat radiating manner, variously dichotomous and rarely anastomosing.

\section{Supplementary description}

Plewes (1996) provided the following comprehensive description of the junior synonym D. ordoplana: "Tiers are visible in hole material through the semi-transparent belemnite, but these are more clearly illustrated in cast material. As individuals increase in size and bore more deeply in a series of tiers, the substrate between the branches becomes lighter in colour due to the borings beneath it. Cast material shows this increase in depth and increased complexity of boring in more detail. Borings begin as a small single tiered rosette which bores parallel to the substrate surface. As the trace becomes larger, the diameter and depth of the boring increases until complex tiered traces result. Up to three tiers of branches have developed in the material cast here. As the boring becomes more extensive there is a concomitant increase in the number of small interconnections with the substrate surface." Also based on SEM observations of epoxy resin casts, Hofmann (1996) provided the complementing information for the junior synonyms $D$. crassa and $D$. fluensis that galleries are oval in cross section (parallel to the substrate surface), have diameters of 100 to $250 \mu \mathrm{m}$, branching points may be considerably widened (300 to $600 \mu \mathrm{m}$ ), branching angles range from $30^{\circ}$ to $70^{\circ}$, the rosette is developed some 50 to $90 \mu \mathrm{m}$ below the substrate surface and distal connections to the latter measure 25 to $50 \mu \mathrm{m}$ in diameter. The diameter of the rosette was reported to range from 1 to $6 \mathrm{~mm}$ (Plewes 1996, measured from plates 22-23; Hofmann 1996, for junior synonyms D. crassa and D. fluensis).

\section{Type material, locality and horizon}

The Morris types are found in a belemnite rostrum (broken in two parts) from the Upper Cretaceous Norfolk Chalk near Norwich, Great Britain. The type stratum was not further specified by Morris, but the Upper Cretaceous at Norfolk comprises the Turonian to lower Maastrichtian and the belemnite genus Belemnitella d'Orbigny, 1840 narrows down the stratigraphical range to the upper Campanian to lower Maastrichtian. The type material is deposited at the Natural History Museum in London (PI A 559). The belemnite contains, apart from many other bioerosion trace fossils, about ten specimens of $D$. dendrina. Morris did not designate a holotype, but one of the specimens (Fig. 2E-G) is encircled with ink and corresponds to the position of trace $6 \mathrm{~b}$ on figure 6 on the original plate (Morris 1851: pl. IV, fig. 6). Based on this circumstance, and due to this specimen clearly exhibiting the diagnostic inlet tunnel, it is hereby designated as the lectotype, rendering the other specimens (e.g., Fig. 2H-I) on the same belemnite paralectotypes.

\section{Remarks}

Dendrina dendrina is primarily distinguished from $D$. belemniticola by the more irregular outline of the rosette and the more loosely spaced galleries that branch in perpendicular to acute angles and often follow a meandering course. In addition, multiple and interconnected tiers are a common phenomenon in D. dendrina that is only rarely observed in D. belemniticola. Distinction is complicated in the case of juvenile specimens or mature specimens with a very dense branching and nearly circular outline. 
Dendrina belemniticola Mägdefrau, 1937

Fig. 3

Dendrina belemniticola Mägdefrau, 1937 (partim): 55, pl. IV, fig 1 (top individual = lectotype).

Dendrina orbiculata Hofmann, 1996: 73, pl. 7, figs 1-4.

Dendrina constans Hofmann, 1996: 76, pl. 7, figs 5-6, pl. 8, figs 1-2.

Dendrina - Quenstedt 1849 (partim): 470, pl. 30, figs 36-37 bottom individuals). - Pictet 1857: 535, pl. CX, fig. 2b. - Radwański 1972 (partim): 257, figs 1-4.

Without name - Quenstedt 1885 (partim): 496, pl. 38, fig. 39 (unlabelled individual above trace labelled "r"). - Dacqué 1921 (partim): 457, fig. 214 (reproduced from Quenstedt 1849).

Dendrina belemniticola - Häntzschel 1962 (partim): W230, fig. 144-2 (reproduced from Mägdefrau 1937); 1975 (partim): W127, fig. $78-7$ (reproduced from Mägdefrau 1937). — Nadjin 1969 (partim): 138, fig. 53 (reproduced from Quenstedt 1849), pl. III, fig. 7, pl. IV, figs 1 (top trace, reproduced from Mägdefrau 1937). — Voigt 1972 (partim): 95, pl. 1, figs 3e, 6 (fig. 3e reproduced from Quenstedt 1849), pl. 2, figs 1d, (above trace labelled "T") (fig. 1 reproduced from Quenstedt 1849, fig. 6 reproduced from Quenstedt 1885), pl. 5, fig. 4. — Nestler 1975 (partim): 108, fig. 159b (reproduced from Quenstedt 1849). — Schnick 1992 (partim): 112, pl. 3, figs 5-6, pl. 4, figs 1-5. - Reich \& Frenzel 2002: 207, pl. 50, fig. 8. — Schulz 2003: 391, fig. 9.10 .71 (top centre). — Košt'ák 2004: 32, fig. 5. — Girod \& Rösner 2013 (partim): 280, fig. 12. — Rudolph 2014 (partim): 18, fig. 23. — Buatois et al. 2017: 161, fig. 75A (lectotype). - Wisshak et al. 2017: 131, figs 3/1-3, 4/3.

Rosetten-Form D - Hofmann \& Vogel 1992: 56, pl. III, fig. C.

Rosetten-Form E - Hofmann \& Vogel 1992: 57, pl. V, figs A-B.

Dendrina orbiculata - Glaub et al. 2007: fig. 21.4/2.

\section{Original diagnosis}

$\mathrm{n} / \mathrm{a}$

\section{Emended diagnosis}

Rosette nearly circular in outline, with densely spaced galleries of relatively constant width and radiating from the centre, bi- and trifurcating at acute angles. Galleries anastomose readily where they meet, or coalesce to produce broad fused sections in the centre of the trace.

\section{Original description}

Galleries form rosettes 1.5 to $6 \mathrm{~mm}$ in diameter, radiating from the centre of the rosette, thereby multiply branching in irregular intervals. Galleries are 0.08 to $0.25 \mathrm{~mm}$ wide, run parallel to the surface of the rostrum, and neither penetrate deeper nor connect to the surface. The diameter of the galleries, measured vertically to the surface of the rostrum, is around $0.05 \mathrm{~mm}$. [Translated from German]

\section{Supplementary description}

Plewes (1996) provided the following description: "Cast material of this ichnospecies shows that the rosettes are prostrate and remain the same thickness across the diameter of the trace. As rosettes become larger, the inner portions coalesce to become a single, flattened hole with an intricate outline and occasional open, elongate portions, remnants of the branches within the rosette. The width of the branches is relatively constant where the branches have not fused, with an average width of $187 \mu \mathrm{m}$ $(\mathrm{n}=9, \mathrm{SD}=50.19)$. Fine tubules from the branches lead to the surface. Diameter of the trace can be up to 3 to $4 \mathrm{~mm}$. Its thickness is approximately $140 \mu \mathrm{m}$ to $200 \mu \mathrm{m}$. Individual borings seem able to avoid other borings." SEM investigations of epoxy casts by Hoffman (1996), for the junior synonyms D. orbiculata and D. constans, added the observations that the rosette is developed 40 to $80 \mu \mathrm{m}$ below the substrate surface, is connected to the latter by rhizoidal appendages of $20-40 \mu \mathrm{m}$ in diameter, and that there is often a radial slit-like incision developed to either side of the centre in many specimens. The 

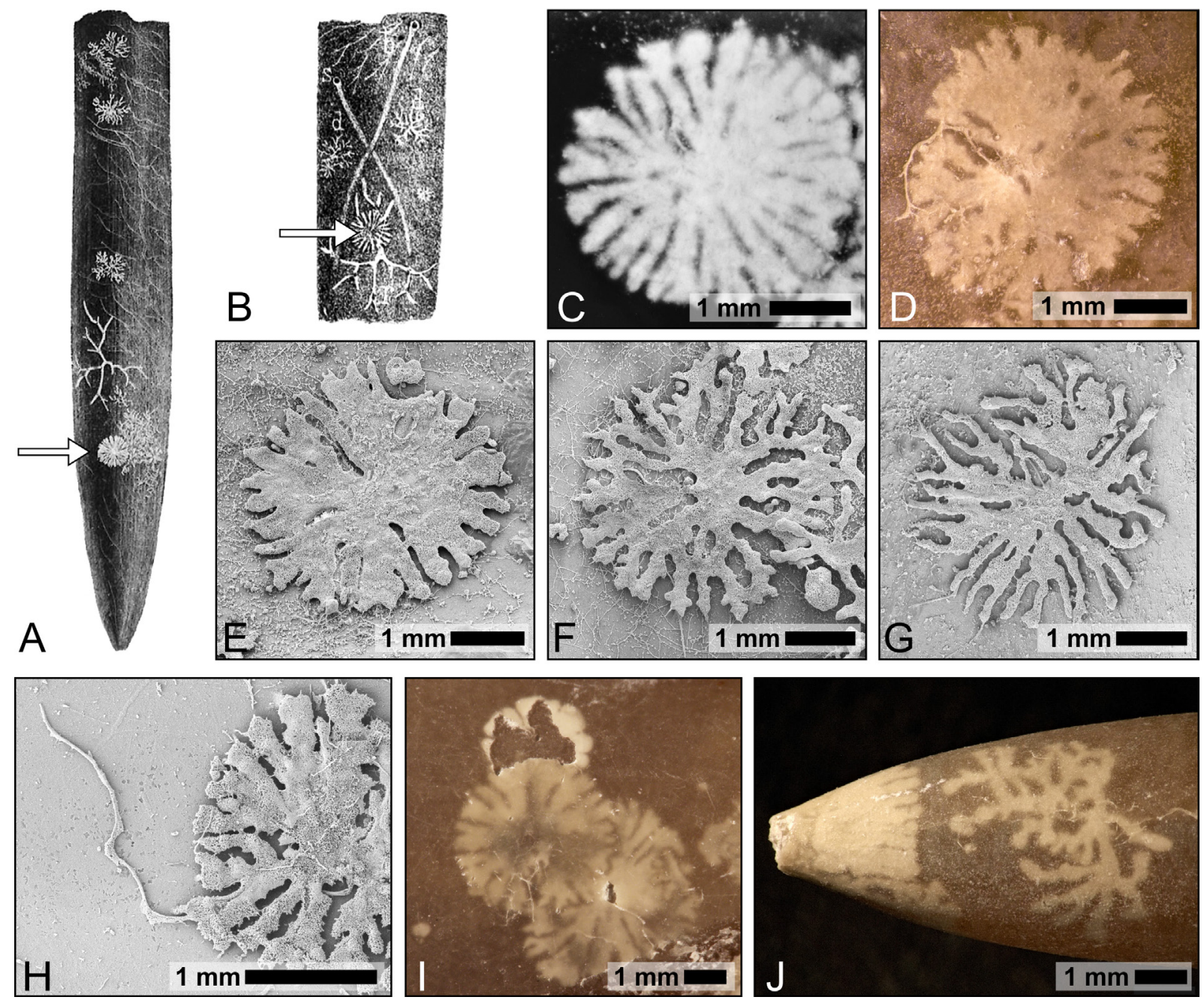

Fig. 3. Dendrina belemniticola Mägdefrau, 1937. A. Original illustration of belemnite with various traces including D. belemniticola (arrow; reproduced from Quenstedt 1849: pl. 30, fig. 36); provenance unresolved. B. Original amalgam, including D. belemniticola (arrow; reproduced from Quenstedt 1885: pl. 38, fig. 39). C. Re-illustration of original Quenstedt Dendrina (reproduced from Plewes 1996: pl. 22, fig. 3); inlet tunnel roughly at $11 \mathrm{~h}$ in this and the following four sub-figures. D. Lectotype of D. belemniticola in an upper Senonian belemnite from Rosenthal near Peine, Germany (compare to Mägdefrau 1937: pl. IV, fig. 1). E. Holotype of junior synonym D. orbiculata Hofmann, 1996. SEM of epoxy cast of an upper Campanian belemnite from Lüneburg, Germany. F. Paratype of junior synonym D. constans Hofmann, 1996. SEM of epoxy cast of a lower Maastrichtian belemnite from Lüneburg, Germany. G. Holotype of junior synonym D. constans. SEM of epoxy cast of a lower Maastrichtian belemnite from Lüneburg, Germany. E-G illustrate the morphological range of D. belemniticola from almost completely fused radiating galleries, to partially fused galleries forming anastomoses, to rarely fused radiating galleries. $\mathbf{H}$. Detail of partly obscured inlet tunnel connecting to centre of a paratype of junior synonym $D$. orbiculata. SEM of epoxy cast of an Upper Cretaceous belemnite from Lüneburg, Germany. I. Rarely observed overlap of $D$. belemniticola in a lower Maastrichtian belemnite from Rügen, Germany. J. Specimen of $D$. belemniticola (left) next to a $D$. dendrina (right) at the very tip of a lower Campanian belemnite from Höver, Germany. 
proximal end of this slit is where the initial inlet tunnel connects to the trace, as exhibited, unmentioned, in both of Hofmann's junior ichnospecies holotypes (see also Schnick 1992). The diameter of the rosette ranges from 1.5 to $4 \mathrm{~mm}$ (Plewes 1996; Hofmann 1996, for junior synonyms D. orbiculata and D. constans); the maximum diameter of $6 \mathrm{~mm}$, as given by Mägdefrau (1937), included specimens of D. dendrina.

\section{Type material, locality and horizon}

Until recently, all three belemnites of the original type material of D. belemniticola were considered lost and only the original plate negatives remained deposited in the collections of the Institut für Geowissenschaften und Geographie in Halle, Germany (MLU.Mäg1937.IV.1, 6 and 8). Plewes (1996) consequently considered the individuals on Quenstedt's original (Quenstedt 1849: pl. 30, fig. 36) as holotypes (e.g., Fig. 3C) - an invalid "neotype" designation in an unpublished thesis. Fortunately, two of the types (corresponding to Mägdefrau's pl. IV, figs 1 and 6) were rediscovered hidden among other belemnites in the systematic collection at Halle, making a neotype designation unnecessary. However, because Mägdefrau's material comprised specimens of both $D$. belemniticola and $D$. dendrina, and owing to the circumstance that he did not specify a holotype, the upper specimen on his plate IV, figure 1 (MLU.Mäg1937.IV.1) is hereby formally designated as the lectotype (Fig. 3D). The other specimen on this figure, as well as the specimens figured on Mägdefrau's plate IV, figures 6 and 8, are within the morphological range of $D$. dendrina. The lectotype is preserved in an upper Senonian belemnite from Rosenthal near Peine, Germany.

\section{Remarks}

The original description actually represents an amalgam of $D$. dendrina and $D$. belemniticola, as Mägdefrau (1937) did not have the methods at hand to study the minute connections to the substrate surface.

In comparison to $D$. dendrina, the rosette of $D$. belemniticola is always nearly circular in outline, and the more densely spaced galleries are less wide and have acute branching points, thus being more radially oriented. In addition, the fusion of galleries is very common, as are the resulting anastomoses, both rarely exhibited characters in D. dendrina. The trace is commonly solitary and tiers are rarely developed. Distinction is complicated in the case of juvenile specimens or mature specimens with a relatively loose and unfused branching.

Dendrina lacerata Hofmann, 1996

Fig. 4

Dendrina lacerata Hofmann, 1996 (partim): 78, pl. 8, figs 3-6.

Piatella-Form - (?) Bundschuh 2000: 69, pl. 10, figs 1-3.

\section{Original diagnosis}

Rosettenförmiges Gangsystem mit sehr breiten und zerlappten Gangformen, häufigen Verschmelzungen einzelner oder mehrerer Gänge und nur wenigen Gangverzweigungen. [Translation: Rosetted boring system with very wide and lobed galleries, common fusion of individual or multiple galleries, and only few ramifications]

\section{Emended diagnosis}

Rosette of irregular outline and with wide and lobed galleries, common fusion, and only few ramifications. Inlet tunnel relatively short and often entirely obscured by the rosette. 


\section{Original description}

The trace shows, similar to Dendrina orbiculata nov. ichnosp., a distinct central area of 0.5 to $1.2 \mathrm{~mm}$ in diameter (mean $0.67 \mathrm{~mm}$ ). For the entire rosette diameters of 1.1 to $2.5 \mathrm{~mm}$ (mean $1.72 \mathrm{~mm}$ ) were measured. Characteristic for this form are the very thick, in planar view irregularly-shaped galleries emerging from the central area. These have a distinctly oval cross section with a 240 to $500 \mu \mathrm{m}$ lateral diameter. Anastomoses and fusion of individual or several galleries are common, whereas branching points are rare. If present, branching is dichotomous. Gallery terminations are rounded. Due to the anastomoses and gallery fusion, the distal galleries of Dendrina lacerata nov. ichnosp. often have larger diameters compared to the proximal ones. Typical for this boring system is furthermore their stacked occurrence and interconnection with tunnels. Galleries connecting to the substrate surface are present at least at the periphery of the rosette (diameter 20 to $40 \mu \mathrm{m}$ ). The entire rosette is developed about 40 to $100 \mu \mathrm{m}$ below the surface of the belemnite rostrum. [Translated from German]

\section{Supplementary description}

Dendrina lacerata is often found connected to the periphery of Calcideletrix anomala or C. flexuosa, forming a composite trace fossil (Fig. 4C and separate section below).

\section{Type material, locality and horizon}

The holotype (Fig. 4A) is preserved in an epoxy resin cast of a Belemnitella mucronata rostrum from the upper Campanian stobaei/basiplana Zone, sampled in the Germania IV quarry near Misburg, Germany.
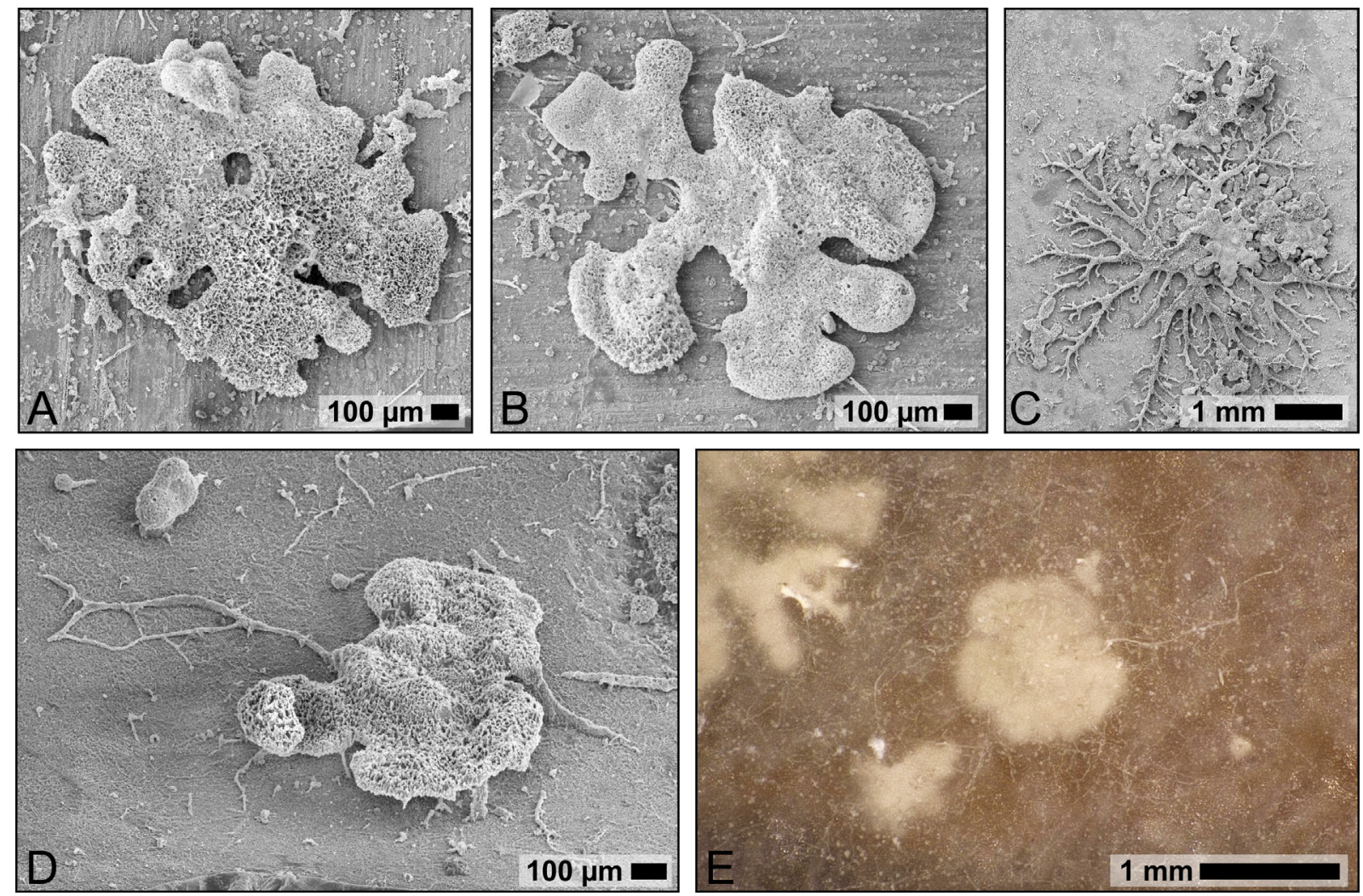

Fig. 4. Dendrina lacerata Hofmann, 1996. A. SEM of holotype in an epoxy cast of an upper Campanian belemnite from Misburg, Germany. B. Paratype on the same cast as the holotype. C. Several paratypes in the periphery of a Calcideletrix anomala from the type locality. D. Oblique view of a specimen in a belemnite from the upper Campanian of Kronsmoor, Germany, illustrating a tubular inlet tunnel on the left and peripheral connections to the substrate surface on the right. E. Surface view of a solitary specimen with inlet canal in a belemnite from the upper Campanian of Misburg, Germany. 
One paratype (Fig. 4B) is found on the same and further paratypes (e.g., Fig. 4C) on three other epoxy casts from belemnite rostra sampled at the type locality and from an outcrop near Lägerdorf, Germany.

\section{Remarks}

A similar form, but either with or without a very thick inlet tunnel, was informally described as PiatellaForm by Bundschuh (2000), potentially extending the stratigraphic record of this ichnospecies and for the ichnogenus to the Silurian, although this assignment is made only tentatively here.

Dendrina lacerata is somewhat smaller in diameter than the two other ichnospecies of Dendrina and in contrast to them it exhibits only a few and much wider lobes, rather than individual or fused galleries. The inlet tunnel usually is less pronounced and shorter than in the other two ichnospecies.

\section{Clionolithes Clarke, 1908}

Olkenbachia Solle, 1938: 156.

Ramodendrina Vogel et al., 1987: 270.

Platydendrina Vogel et al., 1987: 274.

\section{Type ichnospecies}

Clionolithes radicans Clarke, 1908 by subsequent designation in Clarke (1921) or Fenton \& Fenton (1932) (see Remarks below).

\section{Original diagnosis}

$\mathrm{n} / \mathrm{a}$

\section{Emended diagnosis}

Dendritic or rosetted boring network spreading immediately beneath the surface of calcareous skeletal substrates, with tunnels radiating and branching outward from a central node that shows deepest penetration of the trace and may expand into palmate fans. Tunnels taper, cross, or anastomose, and connect to the substrate surface at their terminations or along their entire length.

\section{Original description}

[...] the generic designation Clionolithes for a group [... are] very much smaller [than Vioa prisca = Palaeosabella prisca], much more intricate, arborescent or vagrant tubules. [Clarke (1921), restricting the use of the ichnogenus, previously given with species descriptions only in Clarke (1908).]

\section{Remarks}

The ichnotaxonomical status of Clionolithes experienced a rough history after its original description by Clarke (1908). He did not designate a type ichnospecies or give an ichnogenus diagnosis, but merely described three ichnospecies, including C. priscus (McCoy, 1855) (original designation: Vioa prisca) which is, however, a worm boring (ichnogenus Palaeosabella) and erratic within the suite of his other ichnospecies. Clarke (1921) recognised this misplacement and restricted his earlier definition. In the same account he suggested C. radicans as the type ichnospecies (Clarke 1921: 88) using the partly ambiguous phrasing "It is this form of sponge that may be taken as the type of the genus". Fenton \& Fenton (1932: 43) provided a more explicit definition of Clionolithes and defined C. radicans as the type ichnospecies by subsequent designation, albeit Clarke's statement (Clarke 1921) possibly already fulfilled this purpose. Notwithstanding, Solle (1938) established a new set of morphologically very similar ichnospecies under the new ichnogenus name Olkenbachia. This synonymy was recognised by Teichert (1945), who confirmed the validity of Clionolithes and regarded Olkenbachia as its junior synonym. In contrast, Vogel et al. (1987) considered both, Clionolithes and Olkenbachia, as nomina dubia and instead offered the new replacement ichnogenera Nododendrina, Ramodendrina 
and Platydendrina. Plewes (1996) reinvestigated and illustrated Clarke's type material and found it, contrary to Vogel's statement, sufficiently well-preserved to merit determination of morphological traits, thus again re-validating Clionolithes and in turn considering Nododendrina, Ramodendrina and Platydendrina as junior synonyms. Recently, Furlong \& McRoberts (2014) followed this view and confirmed the junior synonym status of Nododendrina and Ramodendrina. The morphologically similar ichnogenus Granarborus Plewes, 1996 and its two ichnospecies are nomina nuda, since they were not formally published. Irrespective of this repeated rejection and revalidation, a number of further authors (Thomas 1911; Lees \& Thomas 1918; Ruedemann 1925; Branson 1937; Talent 1963) added additional ichnospecies to Clionolithes.

As discussed in the context of the ichnofamily definition above, there is a considerable morphological overlap of some ichnospecies of Clionolithes with Entobia megastoma (Fischer, 1868) and E. dendritica Pleydell \& Jones, 1988, both of which are only vaguely camerate and have a dendritic branching pattern. However, both ichnospecies of Entobia are far larger in dimension. Nevertheless, since the entobians and possibly some of the ichnospecies of Clionolithes are produced by excavating sponges, they partly share the feature of a cuspate microsculpture produced by individual etching cells. This texture is smaller in dimension, thus addressed as "pseudo-chips" by Plewes (1996), and corresponds to the texture exhibited by the two micro-entobians E. nana and E. mikra, both established by Wisshak (2008). This circumstance basically leaves two ichnotaxonomical options, the first one being to consider Clionolithes a junior synonym of Entobia based on the relatively broad emended diagnosis provided by Bromley \& D'Alessandro (1984: 238), which allows the inclusion of non-camerate microborings with a diagnostic cuspate microtexture. The second one is to not consider a cuspate microsculpture as an exclusive morphological feature of entobians and to retain Clionolithes as a distinct ichnogenus. It is the latter option that is advocated herein. In consequence, one could argue that the two entobians E. megastoma and E. dendritica might better be placed within Clionolithes, but this option is not supported here because it would result in a substantial and unfortunate extension of the dendrinid size range, and would only increase the morphological overlap of the two ichnogenera.

Reinvestigation of the original type material of C. lizardensis Lees \& Thomas, 1918 and C. irregularis Fenton \& Fenton, 1932 clearly identified these specimens as Talpina ispp. and not as dendrinids. The same applies for C. canna Price, 1916 and for C. hackberryensis (Thomas, 1911), the latter originally described as a species of Cliona and later placed within Clionolithes by Fenton \& Fenton (1932). Their plesiotypes, however, represent a mix of Talpina isp. and C. radicans and not a distinct ichnospecies. Plewes (1996) revised Talpina, transferred C. hackberryensis to T. hackberryensis and regarded C. irregularis and C. canna as junior synonyms. Likewise, she transferred C. lizardensis to T. lizardensis. The present reinvestigation of the type material concurs with Plewes unpublished revision and both new combinations are thus hereby formally established. The mix of Talpina and Clionolithes is based on an incorrect interpretation that the former ichnogenus represents networks of peripheral galleries originating from the dendritic main chamber of the latter ichnogenus (see description and remarks on C. hackberryensis in Fenton \& Fenton 1932). Another one of Fenton \& Fenton's (1932) ichnospecies, C. fossiger, is a burrow in the internal mould of bivalves reminiscent of the ichnospecies Arachnostega gastrochaenae Bertling, 1992, and is not a bioerosion trace fossil but a senior synonym of the latter ichnospecies. C. reptans was transferred to the ichnogenus Filuroda by Solle (1938). C. quaerens Ruedemann, 1925 is an unidentified tubular epilith. C. pricei Branson, 1937 and C. hunanensis Chow, 1957 have to be considered nomina dubia due to their holotypes currently being lost and the inadequate original illustrations. Hyde (1953) erected three new Clionolithes ichnospecies, with C. implicatus being a junior synonym of Palaeosabella prisca, $C$. ramosus representing an unidentified tubular boring with affinity to Talpina and $C$. ? rectus being another tubular boring system with a characteristic trifurcation pattern that was later transferred to the new ichnogenus Trifurcus by Plewes (1996). Trifurcus, however, was not formally published and is thus a nomen nudum, just like $C$. bullahirsuta which would be a junior synonym of C. alcicornis anyway. 
Fig. 5

Clionolithes radicans Clarke, 1908 (partim): 168, pl. 9, fig. 2, pl. 11, fig. 1 (fig. $1=$ lectotype; pl. 10 and pl. 11, fig. $2=$ ? Calcideletrix flexuosa).

Pyritonema? gigas Fritsch, 1908: 10, pl. 4, figs 2-3.

Olkenbachia hirsuta Solle, 1938 (partim): 162, figs 2-4, 8, 11, 14 (figs 5-7, $10=$ C. cervicornis, figs 9 , $15,17-18=$ C. pannosa and fig. $13=$ Nododendrina nodosa).

Clionolithes radicans - Clarke 1921 (partim): 88, figs 70, 72 (fig. 72 = lectotype, reproduced from Clarke 1908; fig. 71 = ? Calcideletrix flexuosa). - Häntzschel 1962: W230, fig. 142-6 (= lectotype, reproduced from Clarke 1908); 1975: W125, fig. 71-1a-b (fig. 77-1a = lectotype, reproduced from Clarke 1908). — Plewes 1996: 175, pl. 26, figs 1-2, 4 (fig. 2 = lectotype). — Furlong \& McRoberts 2014 (partim): 136, figs 5/1-4, 7 (fig. 5/1 = lectotype; fig 6/1-4 = ?). — Buatois et al. 2017: 161, fig. $75 \mathrm{C}$.

Clionolithes hackberryensis - Fenton \& Fenton 1932 (partim): 44, pl. VI, figs 3-6 (figs 1-2 = Talpina hackberryensis comb. nov.).

Clionolithes ? - (?) Tiedt 1958: 513, fig. 13, pl. 2, fig. 6.

Clionolithes sp. - (?) Easton 1962: 28, pl. 3, fig. 7.

Dendroid-Form II - (?) Schmidt 1992: 89, pl. 11, figs 3-4. — (?) Glaub \& Schmidt 1994: 106, pl. 3, fig. 1.

Dendroid-Form B - (?) Bundschuh 2000: 65, pl. 9, figs 1-2.

Nododendrina nodosa - Klug et al. 2008: 159, pl. 2, fig. 2, pl. 17, fig. 14.

Rosette-shaped borings - (?) Botquelen \& Mayoral 2005: 1061, fig. 2i.

non Clionolithes radicans - Fenton \& Fenton 1932: 43, pl. 6, fig. 7 (? Calcideletrix flexuosa; reproduced from Clarke 1908). — Blissett \& Pickerill 2004: 171, fig. 3/3.

\section{Original diagnosis}

$\mathrm{n} / \mathrm{a}$

\section{Emended diagnosis}

Numerous galleries radiate and branch outward from a small and often elongated central node. Branching dichotomous or irregular, and galleries taper to fine, pointed ends. Branches cross one another rather than coalesce at the edge of the trace. Outline irregular but roughly oval.

\section{Original description}

[...] tubes radiate and branch outward from a center, giving a decided rootlike expression to the resultant very complicated combination of tubes. These branching tubes often unite, fuse or anastomose producing a somewhat irregularly articulated expression. This sponge particularly infested the living and dead shells of the brachiopods, finding entrances less often at the margin than through the pores on the surface of the shell.

\section{Supplementary description}

In the detailed description of the junior synonym Olkenbachia hirsuta, Solle (1938) added the observations that the overall shape of the trace is often roughly oval, branching is dichotomous or irregular, and galleries taper to fine, pointed ends. Furthermore, he pointed out a considerable morphological variability due to varying environmental conditions and different substrate species. The trace is usually less than $4 \mathrm{~mm}$ in diameter but branches may reach up to $3.5 \mathrm{~mm}$ in length (Solle 1938 for junior synonym O. hirsuta). 


\section{Type material, locality and horizon}

Clarke (1908) depicts four brachiopod specimens with numerous C. radicans and one drawing (syntypes). None of these specimens was designated as holotype. Clarke (1921) reproduced all but one of his original illustrations but again did not explicitly address a holotype. Solle (1938) attempted to designate a "Typus" but when doing so referred to two different specimens (Clarke 1908: pl. 11, fig. 2 and 1921: fig. 87). Häntzschel (1962) selected another one of the specimens, a natural cast in an atryparetic shell illustrated with a drawing (Clarke 1908: pl. 11, fig. 1), but this selection alone cannot be considered a valid lectotype designation. Plewes (1996) revisited and illustrated the same specimen, explicitly addressing it as the holotype, but no reasoning for this designation was given, and this was not formally published. Furlong \& McRoberts (2014) were the next to partly revise C. radicans, including another illustration of the same specimen selected by Häntzschel (1962) and by Plewes (1996), but refraining from stating any type attribute. In conclusion, none of the above publications constitute a valid lectotype designation (ICZN article 74), which is herein formally established by selecting the specimen depicted by Clarke (1908: pl. 11, fig. 1) as lectotype (Fig. 5A-C), rendering all other specimens depicted in Clarke 1908 (pl. 9, figs 1-2, pl. 10, pl. 11, fig. 2) as paralectotypes. This selection is in accordance with Häntzschel (1962) and Plewes (1996) and the chosen specimen perfectly matches the wording of Clarke's original description. It is preserved as a natural cast, together with five further specimens, in an Atrypa reticularis brachiopod shell from the Upper Devonian Chemung Beds of Mansfield, Pennsylvania, USA, and is housed in the New York State Museum (NYSM 6702).


Fig. 5. Clionolithes radicans Clarke, 1908. A. Original illustration of the lectotype from the Devonian of Mansfield, Pennsylvania, USA (reproduced from Clarke 1908: pl. 11, fig. 1). B-C. Overview and close-up of a shell of the brachiopod Atrypa bearing the lectotype and a number of further specimens. D. Holotype of junior synonym Olkenbachia hirsuta Solle, 1938 from the Devonian near Koblenz, Germany, reproduced from Solle (1938: fig. 2). E-F. Overview and SEM close-up of one of the paratypes of junior synonym Olkenbachia hirsuta (compare with Solle 1938: fig. 4). 


\section{Remarks}

Solle (1938) studied well-preserved natural casts in brachiopod and bivalve shells from the Devonian near Koblenz, Germany, and established several ichnospecies within the new ichnogenus Olkenbachia. Teichert (1945) stated that Olkenbachia is reminiscent of Clarke's Clionolithes and thus to be regarded as a junior synonym. The holotype of $O$. hirsuta (Fig. 5D) is currently lost, but its original illustration and a reinvestigation of several paratypes confirm the synonymy of the Olkenbachia type ichnospecies $O$. hirsuta with C. radicans (Fig. 5E-F). Olkenbachia simplex is considered to be a poorly preserved $C$. radicans and not a separate ichnospecies. In contrast, a reinvestigation of the holotype of $O$. pannosa identified this ichnospecies as being separate (see below).

\section{Clionolithes palmatus Clarke, 1908}

Fig. 6

Clionolithes palmatus Clarke, 1908: 169, pl. 12, figs 1-2 (fig. 1 = lectotype).

Clionolithes sollei Talent, 1963: 37, pl. 9, figs 1-8.

Clionolithes palmatus - Clarke 1921: 88, figs 92-93 (fig. $92=$ lectotype). - Plewes 1996: 176, pl. 25, figs $7-8$, pl. 26, figs $3,5-8$ (fig. $5=$ lectotype), pl. 27, figs 1-2.

Clionolithes sollei ? - (?) Talent 1963: 37, pl. 10, figs 1-6.

\section{Original diagnosis}

$\mathrm{n} / \mathrm{a}$

\section{Emended diagnosis}

Trace developed along a number of principal branches which curve in a regular manner, forming stretched and longitudinally buckled sheet-like fans or terminating in fine ramifications, producing a trace with a jagged or lobed outline. Branches may radiate from only one side of a main axis. Surface texture largely smooth, tips of branches connect to substrate surface.

\section{Original description}

[...] a singular form assuming broad sparsely branched palmate hollow fronds and found only in the pelecypods and gastropods of the Pertage group (Upper Devonian).

\section{Supplementary description}

A reinvestigation of Clarke's original material and additional specimens cast in epoxy resin allowed Plewes (1996) to provide the following description and morphometrical figures: "If numerous examples of this trace had not been cast, the different morphologies present could have been included in a number of different ichnospecies or even ichnogenera. Extremes of morphology can exist within a single individual; branches can develop into sheet-like extensions, or be delicately branched, as in the original holotype material. [...] Variations in morphology are sometimes confined to different principal axis of one individual; some portions of the trace are delicately branched, others totally devoid of sub-branches. [...] The width of the branches is highly variable, between $35 \mu \mathrm{m}$ and $300 \mu \mathrm{m}$, with a mean of $137 \mu \mathrm{m}$ $(\mathrm{n}=24, \mathrm{SD}=67.62)$. Trace may be a simple rosette up to $3 \mathrm{~mm}$ in diameter or may ramify over the surface of the substrate, confined only by its edges; branches can extend for up to $5 \mathrm{~mm}$ and be 3-4 mm wide." Despite this morphological plasticity, the most diagnostic feature appears to be the sheet-like and laterally widening fans. The maximum size of the trace was measured on the lectotype, which is $7 \mathrm{~mm}$ in diameter. 


\section{Type material, locality and horizon}

Clarke (1908) depicted two drawings (syntypes; Fig. 6A, C), none of which designated as the holotype. Clarke (1921) reproduced both of his original illustrations and again did not explicitly indicate a holotype. Plewes (1996) re-illustrated both of the specimens Clarke based his drawings upon (1908: pl. 12, figs 1-2) and both appear to be damaged. The less damaged specimen (Clarke 1908: pl. 12, fig. 2) was considered as the holotype, whereas the other specimen was qualified as "damaged beyond recognition". However, since her illustration as well as new images of this specimen indicate that this is not the case, and since the trace depicted by Clarke (1908: pl. 12, fig. 1) does match his original description much more closely, it his herein formally selected as the lectotype (Fig. 6A-B), rendering the other specimen a paralectotype (Fig. 6C-D). The lectotype, a natural cast in a Loxopteria dispar shell from the Portage Beds, Upper Devonian, from Correll's Point, New York, USA, is housed in the New York State Museum (NYSM 6697). The paralectotype is a natural cast in a Loxonema danai from the type locality (NYSM 6698).

\section{Remarks}

This ichnospecies is the largest and most variable one of all Clionolithes ichnospecies, but is clearly distinguished from the others by the presence of sheet-like and laterally widening fans, as expressed most prominently in the lectotype. Clionolithes sollei Talent, 1963 shares this diagnostic (and other) features and is thus regarded as a junior synonym.

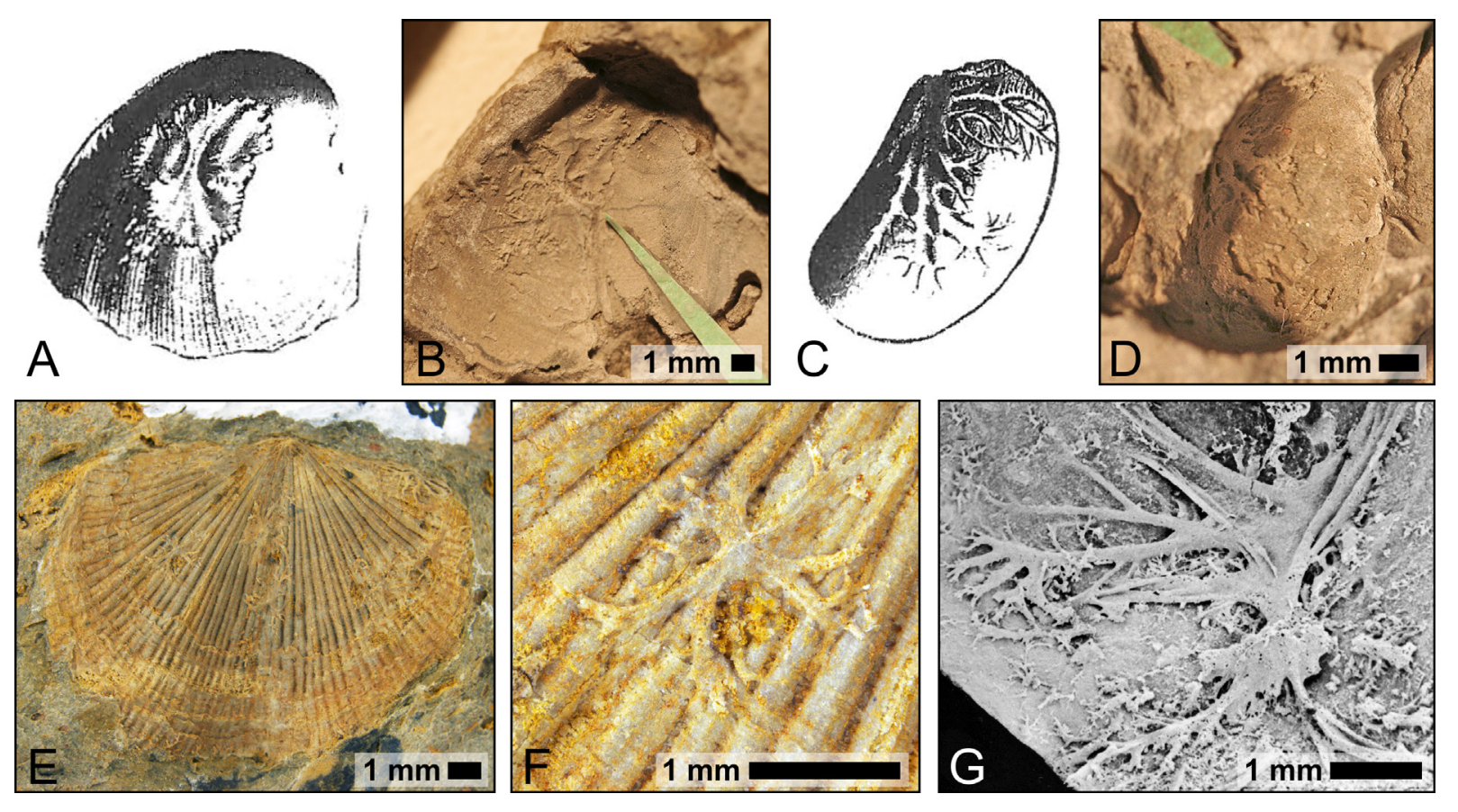

Fig. 6. Clionolithes palmatus Clarke, 1908. A. Original drawing of the lectotype, a natural cast in a shell of Loxopteria dispar Sandberger \& Sandberger, 1857 from the Upper Devonian of New York State, USA (reproduced from Clarke 1908: pl. 12, fig. 1). B. The lectotype in its present state, either slightly damaged or originally idealised. C. Original drawing of the paralectotype, a natural cast in a Loxonema danai Clarke, 1904 from the type locality (reproduced from Clarke 1908: pl. 12, fig. 2). D. Significantly damaged paralectotype. E-F. A number of natural casts in a shell of Leptostrophia Hall \& Clarke, 1892 from the Devonian of Victoria, Australia, including the holotype (close-up in F) and several paratypes of junior synonym Clionolithes sollei Talent, 1963 (compare with Talent 1963: pl. 9, figs 3-8). G. SEM of a specimen cast in epoxy resin by Plewes (1996) from the Devonian of Iowa, USA, illustrating the morphological range within one trace, comprising sheet-like fans and galleries terminating in fine ramifications (reproduced from Plewes 1996: pl. 1, fig. 1). 
Clionolithes pannosus (Solle, 1938) comb. nov.

Fig. 7

Olkenbachia pannosa Solle, 1938: 164, figs 17-18.

Platydendrina platycentrum Vogel et al., 1987: 274, fig. 7.

Olkenbachia hirsuta - Solle 1938 (partim): 162, figs 9, 15, 17-18 (figs 2-4, 8, 11, $14=$ C. radicans, figs $5-7,10=$ C. cervicornis and fig. $13=$ Nododendrina nodosa $)$.

Olkenbachia sp. - Solle 1938: fig. 15.

Platydendrina - Vogel 1987: fig. 6.

Nododendrina convexa - (?) Thuy et al. 2014: fig. $1 \mathrm{~h}$.

\section{Original diagnosis}

Von einem relativ großen, unregelmäßig-lappigen Zentral-Hohlraum laufen kurze, breite, gebogene, nur wenig oder gar nicht verzweigte, in kurze Spitzen ausgezogene Gänge aus. [Translation: from a relatively large, irregularly-lobed central cavity, short, wide, bent, slightly branched or unbranched galleries with short pointed terminations emerge.]

\section{Emended diagnosis}

From a flat and irregularly-lobed central cavity with a smooth surface, short and rapidly tapering galleries emerge, which are little ramified, may form anastomoses, end in short pointed terminations, and connect to the substrate surface by short spiny outgrowths.

\section{Original description}

The central cavity exhibits an irregularly-lobed shape and is relatively large with $1 \mathrm{~mm}$ in longest diameter and $0.6 \mathrm{~mm}$ in maximum width. From this central cavity irregular, short, wide, bent, rarely
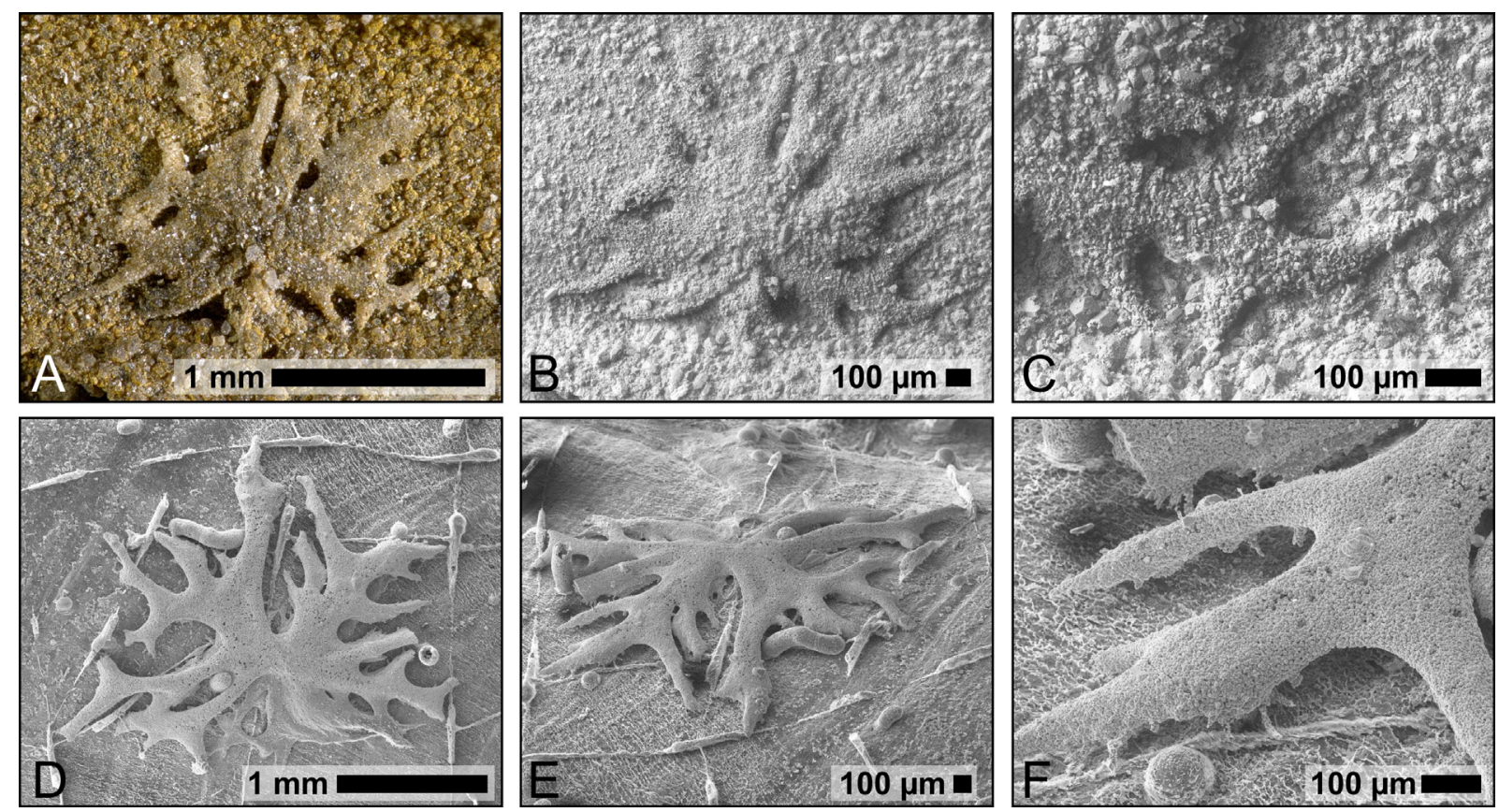

Fig. 7. Clionolithes pannosus (Solle, 1938) comb. nov. A. Holotype preserved as natural cast in a Devonian brachiopod shell from the Mosel Valley near Münstermaifeld, Germany. B-C. SEM overview and close-up of the holotype. D-F. SEM planar view, oblique view and close-up of pyritised and resinembedded holotype of junior synonym Platydendrina platycentrum Vogel et al., 1987 in a shell of Mediospirifer Bublichenko, 1959 from the Middle Devonian of New York State, USA. 
nearly straight galleries emerge in all directions, none of which surpass the diameter of the main cavities in length. Only few of these galleries branch once or twice; they terminate in short pointed ends. The diameter of the branches exceeds $0.2 \mathrm{~mm}$. The overall appearance of the trace is plump. [Translated from German]

\section{Supplementary description}

(Note: numbers in square brackets indicate $\mathrm{n}=$ number of specimens measured.) The detailed original diagnosis of the junior synonym Platydendrina platycentrum by Vogel et al. (1987) adds the following observations and morphometrical data: "Palmate, repeatedly branched system, up to $3 \mathrm{~mm}(1.03 \pm 0.56$ [16]) in diameter. Central area is occupied by a large flat surface that gradually grades into the branches. Branches diverge at angles ranging from $32^{\circ}$ to $100^{\circ}(58 \pm 16$ [58]). The margins between branches are scalloped forming deep rounded embayments. The width of the primary branches at the base is $50-300$ $\mu \mathrm{m}(134 \pm 63[66])$, the secondary branches $20-60 \mu \mathrm{m}(40 \pm 11$ [82]), whereas the tertiary (distal) branches are 5-20 $\mu \mathrm{m}(16 \pm 8$ [54]). Thus, there is a substantial decrease in width from the proximal to the distal branches. The branches end with tiny rhizoidal appendages only a few micrometres wide, which connect to the substrate surface. The anastomoses are common sometimes leaving rounded holes. The branches are depressed in cross section. The dorsal surfaces (interior with respect to the shell) of Platydendrina are smooth, whereas its ventral side is beset by spiny outgrowths that connect to the substrate surface."

\section{Type material, locality and horizon}

The holotype (Fig. 7A-C) is preserved as a natural cast in a brachiopod shell from the Flaser-Schiefer, Kondel-Gruppe, Oberkoblenz, Devonian, from Brodenbach Valley near the river Mosel in a small quarry opposite the Teufelslei near Münstermaifeld, Germany. Deposited in the brachiopod collection at the Senckenberg Institute in Frankfurt, Germany (SMF XXVI 166a).

\section{Remarks}

Originally established within the ichnogenus Olkenbachia, which is a junior synonym of Clionolithes. The spelling has been changed to the masculine pannosus in order to be consistent with the ichnogenus in gender.

Compared to the other ichnospecies of Clionolithes, C. pannosus exhibits the shortest and least ramified galleries and the relatively largest and distinctly flat central cavity. In contrast to most other ichnospecies it may anastomose. Among all Clionolithes, the overall morphological appearance of this trace is closest to that of Dendrina.

Clionolithes cervicornis (Vogel, Golubic \& Brett, 1987) Fig. 8

Ramodendrina cervicornis Vogel et al., 1987: 270, fig. 5.

"Chondrites" symmetricus Solle, 1938 (partim?): 168, fig. 19 (fig. 20 = a brachiopod muscle scar).

Olkenbachia hirsuta - Solle 1938 (partim): 162, figs 5-7, 10 (figs 2-4, 8, 11, $14=$ C. radicans, figs 9 , $15,17-18=C$. pannosus and fig. $13=$ Nododendrina nodosa)

Dendroid Form 1 - (?) Vogel \& Brett 2009: 15, fig. 29.

Clionolithes cervicornis - Furlong \& McRoberts 2014: 138, fig. 6.2. 


\section{Original diagnosis}

Rosette-shaped repeatedly branched systems up to $2.5 \mathrm{~mm}(1.50 \pm 0.40$ [10]) in diameter. Branches diverge from the main trunk, spreading radially in straight line or slightly curved, at angles ranging from $40^{\circ}$ to $95^{\circ}(64 \pm 13[50])$. The main trunk is $80-250 \mu \mathrm{m}$ wide. The primary branches (those proximal to the trunk) are 60-225 $\mu \mathrm{m}(133 \pm 44$ [24]) wide, the distal branches are $25-85 \mu \mathrm{m}(52 \pm 11$ [100]) wide. The branches often adhere closely to the substrate surface. They have smooth and rounded surfaces, and are circular in cross section. They do not taper and have rounded, rarely pointed tips. Branch diameter decreases only slightly from primary to secondary and tertiary (distal) branches, and remains constant (or even increases slightly) between branching points. The branching varies in density, without anastomoses. The main aperture to the surface was not detected.

\section{Emended diagnosis}

Branches with nearly constant diameter diverge from the main trunk, spreading and bifurcating radially in straight or slightly curved lines, adhere closely to the substrate surface and do not anastomose. They have smooth and rounded surfaces and rounded, rarely pointed tips.

\section{Original description}

$\mathrm{n} / \mathrm{a}$, but see detailed original diagnosis.
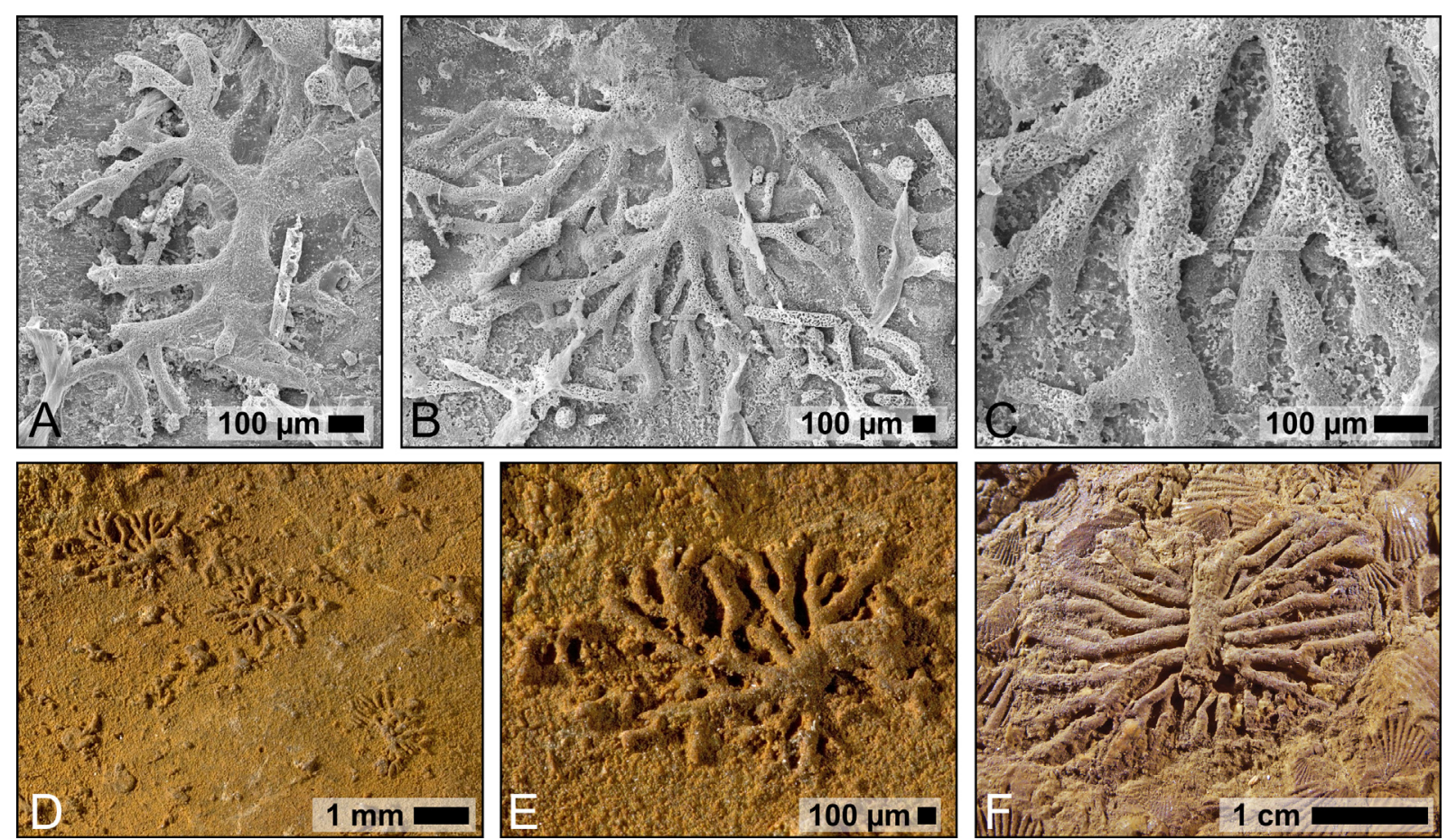

Fig. 8. Clionolithes cervicornis (Vogel, Golubic \& Brett, 1987). A. SEM of pyritised and epoxycast holotype in a Devonian brachiopod shell from New York State, USA. B-C. SEM overview and close-up of another specimen from the original material of Vogel et al., recorded in a coral substrate. D-E. Overview and close-up of several natural casts that are part of the suite of paratypes of Olkenbachia hirsuta Solle, 1938 (junior synonym of Clionolithes radicans Clarke, 1908), from the Devonian near Koblenz, Germany (compare with Solle 1938: fig. 5). F. Holotype of nomen nudum "Chondrites" symmetricus (Solle 1938), a morphologically similar (cf.) but unusually large specimen from the Devonian near Koblenz, Germany. 


\section{Type material, locality and horizon}

The holotype (Fig. 8A) was epoxy cast in a shell of the brachiopod Athyris McCoy, 1844 from the Otisco Member, Middle Devonian, sampled at a cliff exposure along a railroad cut $300 \mathrm{~m}$ E of Portland Point, Cayuga County, New York, USA. It is deposited at the Institut für Geowissenschaften, GoetheUniversität, Frankfurt, Germany (Bo 1/4).

\section{Remarks}

Originally established within the ichnogenus Ramodendrina, which according to Furlong \& McRoberts (2014) is a junior synonym of Clionolithes. A number of paratypes of Olkenbachia hirsuta (junior synonym of $C$. radicans; Fig. 8D-E) are morphologically reminiscent of $C$. cervicornis, as is a very large single specimen that was only tentatively addressed by Solle (1938) as "Chondrites" symmetricus (Fig. 8F).

Clionolithes cervicornis is distinguished from other ichnospecies of Clionolithes by the nearly constant diameter of the radiating galleries, their close connection to the substrate surface (= open roof) and the distinctly rounded terminations.

Clionolithes alcicornis (Vogel, Golubic \& Brett, 1987) comb. nov.

Fig. 9

Ramodendrina alcicornis Vogel et al., 1987: 272, fig. 6.

Clionolithes bullahirsuta Plewes, 1996: 178, pl. 27, figs 3-7, pl. 28, figs 1-8.

Ramodendrina - Vogel 1987: fig. 5.

\section{Original diagnosis}

Rosette-shaped repeatedly branched systems up to $2 \mathrm{~mm}(1.41 \pm 0.34$ [16]) in diameter. Branches diverge from the main trunk spreading radially, curved in a characteristic clawlike fashion at angles ranging from $40^{\circ}$ to $115^{\circ}(72 \pm 17$ [50]). The main trunk is $75-190 \mu \mathrm{m}(142 \pm 40$ [7]) wide. The primary branches range from 53 to $136 \mu \mathrm{m}$ (95 \pm 19 [50]), the secondary branches from 31 to $66 \mu \mathrm{m}$ (51 \pm 11 [50]), and the tertiary branches from 12 to $45 \mu \mathrm{m}$ (26 \pm 9 [37]) in diameter. They have smooth and rounded surfaces, and are circular in cross section. The branches taper toward pointed tips. There is a significant decrease in diameter from primary to secondary and tertiary (distal) branches, and the diameter between individual branching points remains constant or decreases. The branching varies in density, without anastomoses. The main aperture to the surface was not detected.

\section{Emended diagnosis}

Branches diverge from the flat and elongated main trunk, spreading radially and in one plane, often in straight lines, ramifying in varying density at angles between $40^{\circ}$ and $115^{\circ}$ without forming anastomoses, tapering toward pointed tips. Often with a distinctive cuspate texture and fine filaments scattered over the entire surface, but most numerous on the edges and sides of the branches.

\section{Original description}

$\mathrm{n} / \mathrm{a}$, but see detailed original diagnosis.

\section{Supplementary description}

When erecting the junior synonym (and nomen nudum) C. bullahirsuta, Plewes (1996) made the following additional observations, particularly concerning the surface texture that is only poorly 
preserved in the Devonian holotype: "The overall oval shape and the characteristic texture of the trace are constant attributes (although the presence of the texture is dependent on the preservation and the quality of the cast). Whole rosette up to $3 \mathrm{~mm}$ in diameter. Even within the holotype the branches vary in their morphology, and frequency. However, there are recurring features: branches may have a sweeping shape and taper towards the pointed, but not filamentous, ends. Although branches do anastomose, sometimes they do not fuse and appear on the casts as still separate. The width of branches varies between $40 \mu \mathrm{m}$ and $170 \mu \mathrm{m}$ with a mean of $93 \mu \mathrm{m}(\mathrm{n}=16, \mathrm{SD}=48.52)$. Some specimens show a curious loop on one side. The pseudochip sculpture is also highly variable and measured across the widest point can be up to $50 \mu \mathrm{m}$ or as small as $7 \mu \mathrm{m}$ the average is $18 \mu \mathrm{m}(\mathrm{n}=19, \mathrm{SD}=9.99)$. The hairs also vary in length, although this is probably due more to the preservation of the substrate than variation between individuals. The width of the hairs is more constant, with a mean of $2.5 \mu \mathrm{m}(\mathrm{n}=15, \mathrm{SD}=0.92)$."

\section{Type material, locality and horizon}

The holotype (Fig. 9A-B) was epoxy cast in a Mediospirifer brachiopod shell from the Windom Member, Middle Devonian, sampled at Barnum Creek quarry just W of NY highway 89 and $0.2 \mathrm{~km}$ $\mathrm{S}$ of the Ovid/Romulus town line, Seneca County, New York, USA. It is deposited at the Institut für Geowissenschaften, Goethe-Universität, Frankfurt, Germany (Bo 1/8).
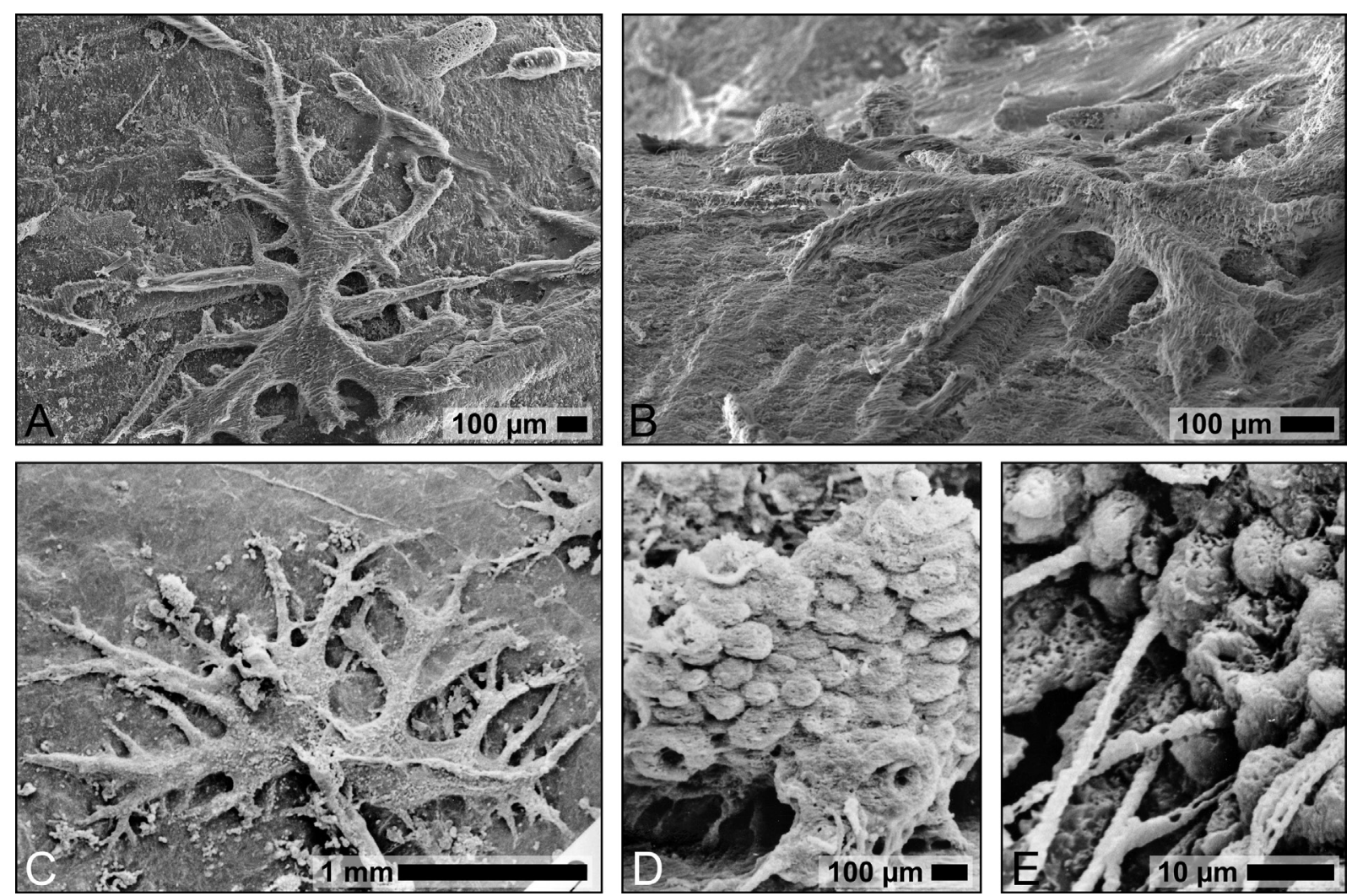

Fig. 9. Clionolithes alcicornis (Vogel, Golubic \& Brett, 1987) comb. nov. A-B. SEM planar and oblique views of the holotype epoxy cast (together with bryozoan borings) recorded in a Devonian brachiopod shell from New York State, USA. C. SEM of the holotype of junior synonym C. bullahirsuta Plewes, 1996 from the Lower Jurassic of Yorkshire, UK (reproduced from Plewes 1996: pl. 28, fig. 1). D. Close-up of C, illustrating the characteristic cuspate microtexture (reproduced from Plewes 1996: pl. 28, fig. 3). E. SEM close-up of another specimen showing additional hairy filaments (reproduced from Plewes 1996: pl. 28, fig. 7). 


\section{Remarks}

Originally established within the ichnogenus Ramodendrina, which is a junior synonym of Clionolithes. The nomen nudum (not formally published) Clionolithes bullahirsuta Plewes, 1996, from the Lower Jurassic of Yorkshire, UK, is herein regarded as a junior synonym.

Differs from other ichnospecies of Clionolithes by its wide and straight central trunk, the flat overall morphology, with an orientation of the entire trace more or less along the same plane parallel to the substrate surface, the often straight path of the ramifying galleries, and (if preserved) the distinctive cuspate microsculpture (Fig. 9D-E).

Clionolithes convexus (Hofmann, 1996) comb. nov.

Fig. 10

Nododendrina convexa Hofmann, 1996: 82, pl. 9, figs 5-6, pl. 10, figs 1-2.

non Nododendrina convexa - Thuy et al. 2014: fig. 1h (? C. pannosus).

\section{Original diagnosis}

Rosettenartiges Bohrgangsystem in konvex-gewölbter Form mit starkem Gang im zentralen Bereich, von dem aus dünner werdende Gänge in die peripheren Rosettenbereiche abzweigen. [Translation: Rosetted boring system in a convex-arched shape with prominent main gallery in the centre, from which galleries emerge and taper towards the peripheral area.]

\section{Emended diagnosis}

Oblique inlet gallery leading to a wide, convex-arched and elongated main cavity in the centre of the trace, from which galleries emerge and sharply taper towards the periphery and towards the substrate surface, forming numerous fine connections. Surface texture smooth, except for inlet tunnel, which may bear short and spiny protrusions.

\section{Original description}

The rosette consists of a very pronounced gallery in the central area (diameter 100 to $150 \mu \mathrm{m}$ ), from where few and slightly thinner galleries branch (diameter 60 to $80 \mu \mathrm{m}$ ). From these, further galleries
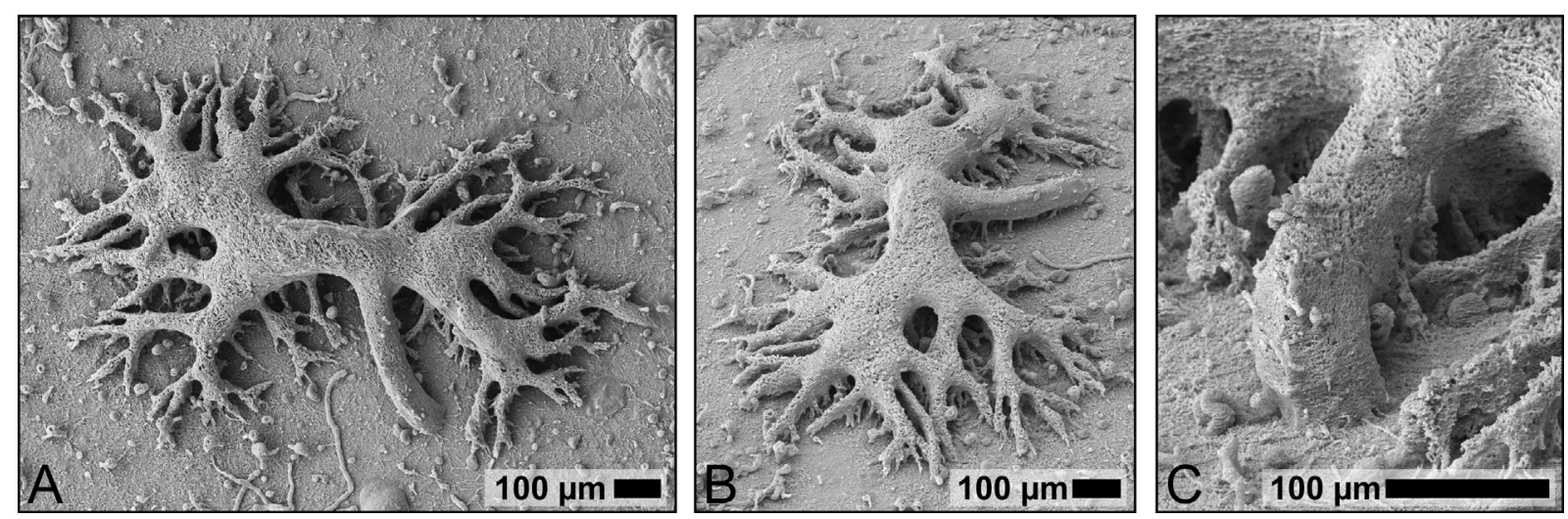

Fig. 10. Clionolithes convexus (Hofmann, 1996) comb. nov. A-C. SEM of the lectotype in planar view, oblique view and a detail, preserved in an epoxy cast from an Upper Cretaceous Ostrea shell from the Swedish island Ivö. Note the prominent initial tunnel with a slightly hairy texture leading to the main trunk of the trace. 
emerge, ramify and taper. Like in Rosetten-Form A, there is a remarkably large penetration depth of the boring trace in the shell [...] exceeding that of all other rosette types. Distances of up to $400 \mu \mathrm{m}$ to the shell surface were measured. This penetration depth, together with the relatively small diameter of the rosette (ca 1 to $2 \mathrm{~mm}$ ), lead to a nearly dome-shaped morphology of the boring trace in casts and its characteristic appearance. [Translated from German]

\section{Supplementary description}

A prominent and diagnostic feature not addressed in the original description is the arched initial gallery leading from the initial vertical point of entry to the main trunk of the trace. This gallery is present not only in the lectotype (Fig. 10), but also in all of the reinvestigated paralectotypes, and in contrast to the main trace often exhibits a slight hairy texture. Thereby the course of the initial gallery ranges from an immediately bent and almost prostrate orientation to a more arcuate morphology that exceeds the main trace in penetration depth.

\section{Type material, locality and horizon}

The type material comprises various specimens in several epoxy resin casts of Ostrea oyster shells sampled in an old quarry near the northern limit of the Swedish lake island Ivö; lower Campanian, Cretaceous. Of the two specimens on the cast indicated as "holotype", the one illustrated on Hofmann's plate 9, figure 5-6 is hereby designated as the lectotype (Fig. 10A-C), rendering the other specimens on this and three other casts paralectotypes. The type material is deposited at the Institut für Geowissenschaften, Goethe Universität, Frankfurt, Germany (Bo 5/146: 146.1 = lectotype and one paralectotype, 146.2 to 146.4 = further paralectotypes).

\section{Remarks}

Originally established within the ichnogenus Nododendrina, which is a junior synonym of Olkenbachia, which in turn is a junior synonym of Clionolithes. Spelling changed to the masculine convexus in order to correlate with the ichnogenus in gender.

Calcideletrix Mägdefrau, 1937

\section{Type ichnospecies}

Calcideletrix flexuosa Mägdefrau, 1937, by subsequent designation in Häntzschel (1962).

\section{Original diagnosis}

$\mathrm{n} / \mathrm{a}$

\section{Emended diagnosis}

Dendritic boring system in calcareous skeletal substrates with a series of main axes that give the trace a lobed appearance. Inner branches may anastomose or leave blind-ending branches. Trace closely prostrate and with many contacts to the substrate surface.

\section{Original description}

Shrublike ramified cavity system, branches 0.02 to $0.1 \mathrm{~mm}$ in diameter, with one or more openings. [Translated from German]

\section{Supplementary description}

Based on the analysis of epoxy casts, Plewes (1996) added the following general observations: "To a greater extent than Clionolithes this trace is neither a true rosette nor a network but an intermediate 
between the two. It always extends along a series of curved or linear axes and so there is no immediate 'point of origin' from which all branches proceed. Branches anastomose but not extensively enough to form a true network; within the inner meshwork portion of the trace there are always blind-ending branches. The degree of variability of the branch widths differs between species. This and the density between branches is the main difference between them."

\section{Remarks}

Häntzschel (1975), in the second edition of the trace fossil volume of the Treatise on Invertebrate Paleontology, claimed that it was him in the first edition of the trace fossil volume of the Treatise (Häntzschel 1962) who has to be regarded as the first author of Calcideletrix, based on the assumption that the original description by Mägdefrau is to be considered a nomen nudum due to a missing designation of a type ichnospecies. However, the designation of a type ichnospecies became a requirement only in 2000 with the $4^{\text {th }}$ edition of the ICZN, and Mägdefrau's original description is thus to be regarded as readily valid.

The ichnogenus was established with the two ichnospecies C. flexuosa and C. breviramosa. Based on close morphological similarities, this couple is herein complemented by Dendrina anomala Mägdefrau, 1937 and Polyactina fastigata Radtke, 1991, extending the morphological range and the size range of Calcideletrix. These four ichnospecies form a morphological series that communicates between the morphological end members of Clionolithes (in particular C. radicans) and Dictyoporus (in particular D. nodosus).

\section{Calcideletrix flexuosa Mägdefrau, 1937}

Fig. 11

Calcideletrix flexuosa Mägdefrau, 1937: 57, pl. IV, fig. 4.

Dendrina brachiopodicola Hofmann, 1996: 80, pl. 9, figs 1-4.

Clionolithes radicans - Clarke 1908 (partim): 168, pl. 10, pl. 11, fig. 2; 1921 (partim): 88, fig. 71 (drawing based on photograph in Clarke 1908).

Calcideletrix flexuosa - Häntzschel 1962: W228, fig. 142-4 (reproduced from Mägdefrau 1937); 1975: W124, fig. 77-4b (reproduced from Mägdefrau 1937). — Pugaczewska 1965: 76, pl. I, fig. 3; (?) 1970: 428, pl. I, fig. 2, pl. II, fig. 2 (poor illustrations). - Nadjin 1969: 138, pl. IV, fig. 4 (reproduced from Mägdefrau 1937). - Plewes 1996 (partim): 188, pl. 31, figs 7-8, pl. 33, figs 1-7, pl. 34, figs 1-4 (pl. 34, figs 5-6 = Dictyoporus nodosus). - Buatois et al. 2017: 161, fig. 75B (holotype). - Wisshak et al. 2017: 131, figs 3/4, 4/4.

Rosetten-Form G - Hofmann \& Vogel 1992: 57, pl. IV, fig. B.

Without name - Reich \& Frenzel 2002 (partim): 208, pl. 50, fig. 7.

Calcideletrix - Whittlesea 2005: 18, fig. 3.

Dendrina anomala - Rudolph 2014 (partim): 19, fig. 24 (specimen on the left).

non Calcideletrix flexuosa - Ghare 1982: 132, pl. 1, fig. 5 (=Calcideletrix breviramosa). — (?) Košt'ák 2004: 32, fig. 11 (? Dictyoporus nodosus). — (?) Stiller 2005: 406, pl. II, figs 3, 15 (poor illustration).

\section{Original diagnosis}

$\mathrm{n} / \mathrm{a}$

\section{Emended diagnosis}

Highly ramified, with most branches remaining roughly the same width up to their tapering ends. Branches ramify in a relatively straight manner, although curves develop at irregular intervals. Branches 

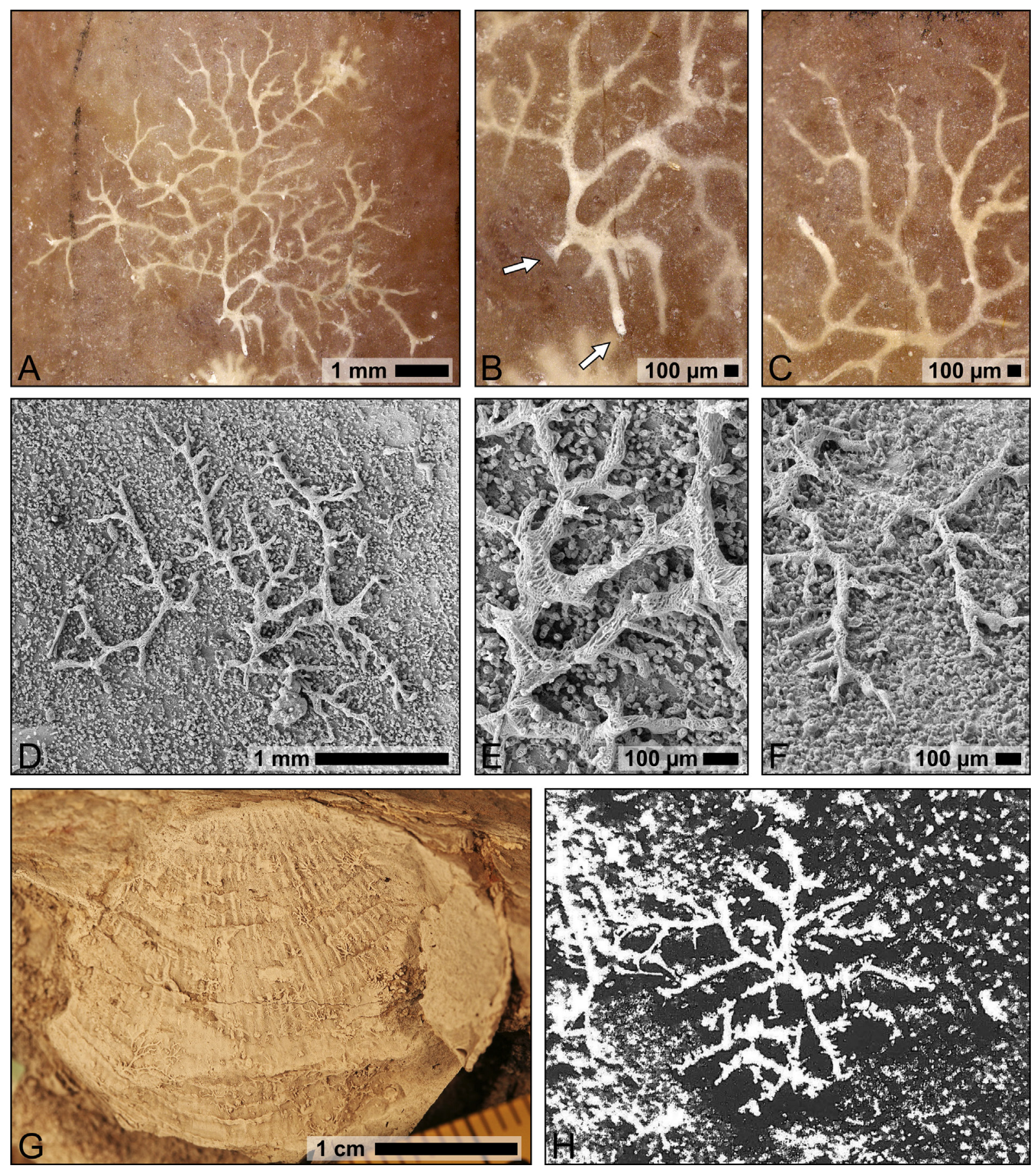

Fig. 11. Calcideletrix flexuosa Mägdefrau, 1937. A-C. Holotype in an Upper Cretaceous belemnite rostrum from Misburg, Germany. Close-up in B illustrates anastomosis and two potential points of initial entry (arrows). Close-up in C shows peripheral ramification. D-F. Respective SEM views of an epoxy casts of the holotype of junior synonym D. brachiopodicola Hofmann, 1996, illustrating the very close morphological resemblance of the trace in a belemnite vs a brachiopod substrate. G. Natural casts in a Devonian brachiopod with several C. flexuosa (original of Clarke 1908: pl. 10; damaged since original publication). H. Another silicified cast in a Devonian brachiopod shell (reproduced from Clarke 1908: pl. 11, fig. 2). 
ramify in such a way as to cover the space between branches almost equally. Anastomosis is rare and restricted to the centre of the trace.

\section{Original description}

Channels strongly ramified, $0.04-0.09 \mathrm{~mm}$ in diameter. Only the main channel, at the basis of the shrub, opens to the surface, while the side channels do not penetrate to the surface of the belemnite rostrum. [Translated from German]

\section{Supplementary description}

Based on cast material, Plewes (1996) added the following observations: "Cast material shows that the profile of the branches is rounded and sometimes shows a hint of the bubbly texture reminiscent of, but not as pronounced as that seen in C. anomala. Width of the branches varies between $25 \mu \mathrm{m}$ and $250 \mu \mathrm{m}$, with a mean of $98 \mu \mathrm{m}(\mathrm{n}=18, \mathrm{SD}=50.08)$. Surface texture may also include hair-like filaments. These are between $1 \mu \mathrm{m}$ and $2.5 \mu \mathrm{m}$ in width and vary greatly in length. The loops which form as a result of anastomoses between branches within the main body of the trace vary in size and may enclose other blind ending branches. Branching angle varies greatly but is between $90^{\circ}$ and $45^{\circ}$, and branching may be polychotomous or dichotomous. Nodes are sometimes swollen and form rounded irregular edges, especially if the branching point is not a simple dichotomy. The spacing between branches varies but is between $380 \mu \mathrm{m}$ and $900 \mu \mathrm{m}(\mathrm{n}=9, \mathrm{SD}=245.9)$." Hofmann (1996) additionally gave a size range of the junior synonym $D$. brachiopodicola of 1.3 to $3.7 \mathrm{~mm}$.

\section{Type material, locality and horizon}

Holotype (Fig. 11A-C) preserved in rostrum of Belemnitella mucronata from the Upper Cretaceous of Misburg near Hannover, Germany, deposited in the collection of the Institut für Geowissenschaften und Geographie, Halle, Germany (MLU.Mäg1937.IV.4).

\section{Remarks}

Hofmann's Dendrina brachiopodicola very closely resembles C. flexuosa in morphology and dimensions, and was established as a separate taxon based on its vertically oriented oval gallery cross section only. However, Mägdefrau did not specify the tunnel cross-section and this character alone does not justify its use as the ichnotaxobase for a separate ichnospecies, let alone an ichnospecies within a different ichnogenus, and it is thus regarded as a junior synonym herein.

Calcideletrix breviramosa Mägdefrau, 1937

Fig. 12

Calcideletrix breviramosa Mägdefrau, 1937: 58, pl. IV, fig. 9.

Calcideletrix breviramosa - Häntzschel 1962: W228, fig. 142-5 (reproduced from Mägdefrau 1937); 1975: W124, fig. 77-4a (reproduced from Mägdefrau 1937). — Nadjin 1969: 138, pl. IV, fig. 9 (reproduced from Mägdefrau 1937). - (?) Marcinowski 1972: 247, pl. 2, fig. 2 (poor illustration). Calcideletrix flexuosa - Ghare 1982: 132, pl. 1, fig. 5.

non Calcideletrix breviramosa - Ghare 1982: 132, pl. 1, fig. 6 (= Dictyoporus nodosus). — (?) Košt’ák 2004: 32, fig. 12 (? Dictyoporus nodosus).

\section{Original diagnosis}

$\mathrm{n} / \mathrm{a}$ 


\section{Emended diagnosis}

Extended system with mainly straight and partly bending or bifurcating main tunnel of constant diameter, from which numerous lateral secondary tunnels of same diameter emerge and taper or connect to the substrate surface. No true anastomosis and only little widening at branching points.

\section{Original description}

Distinctly structured in main and secondary branches, both of same diameter $(0.02-0.04 \mathrm{~mm})$. The secondary branches mostly diverge at an angle of $60^{\circ}$ from the main channel and almost all penetrate the surface of the belemnite rostrum, similar to Talpina ramosa. [Translated from German]

\section{Type material, locality and horizon}

Holotype (Fig. 12A-C) preserved in rostrum of an Actinocamax Miller, 1826 (belemnite) from the Upper Cretaceous of Misburg near Hannover, Germany, deposited in the collections of the Institut für Geowissenschaften und Geographie, Halle, Germany (MLU.Mäg1937.IV.9).

\section{Remarks}

Due to the lack of a defined centre or point of entry, this ichnospecies is rather an extended tunnel system than a dendrinid trace and represents a morphological end member of Calcideletrix. This feature and the relatively constant diameter of the main and secondary branches distinguish $C$. breviramosa from the other ichnospecies of Calcideletrix.

\section{Calcideletrix anomala (Mägdefrau, 1937) comb. nov.}

Fig. 13

Dendrina anomala Mägdefrau, 1937: 55, pl. IV, fig. 5.

Dendrina - Radwański 1972 (partim): 257, figs 1-4.

Dendrina anomala - (?) Marcinowski 1972: 247, pl. 1, fig. 2 (poor illustration). — (?) Kutscher 1972: 27, fig. 6. — Nestler 1975: 108, fig. 159c (reproduced from Quenstedt 1849). — Hofmann 1996:
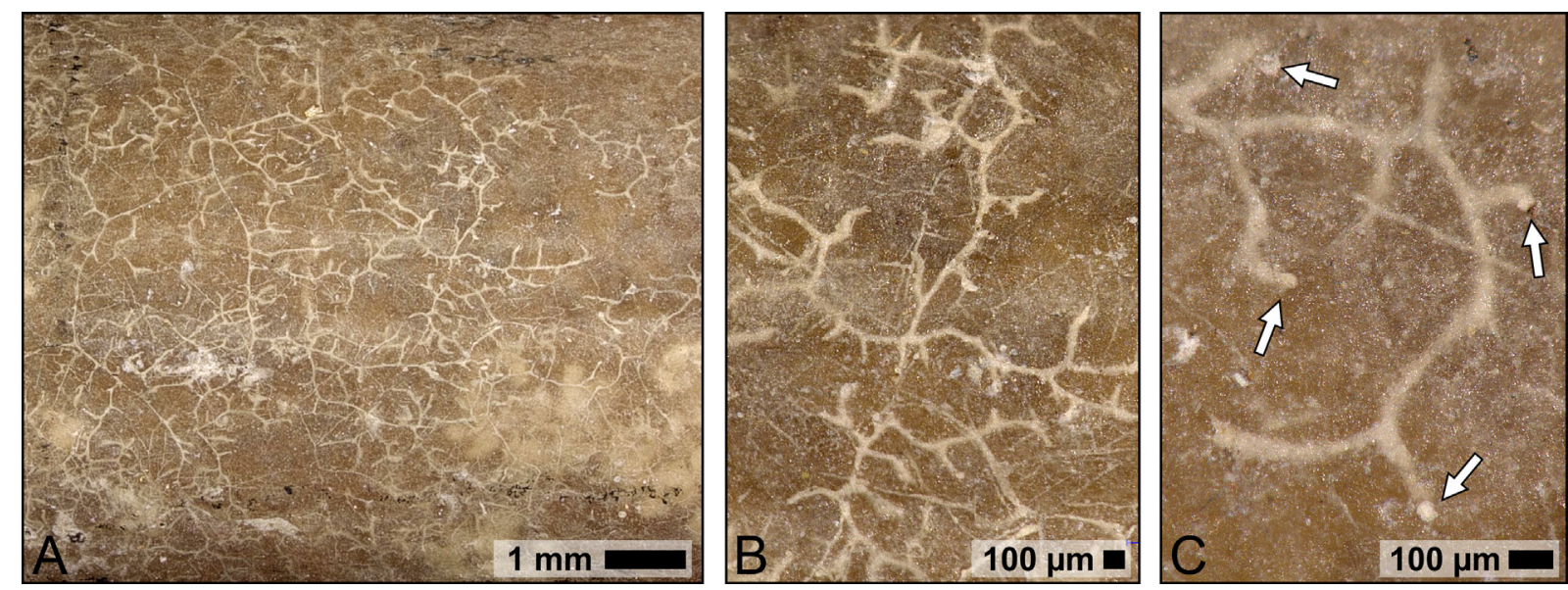

Fig. 12. Calcideletrix breviramosa Mägdefrau, 1937. A-C. Holotype covering several square centimetres of an Upper Cretaceous belemnite from Misburg, Germany. Close-up in B shows main tunnels with lateral secondary galleries and close-up in C illustrates connections to the substrate surface at the end of the secondary branches (arrows). 
67, pl. 5, figs 5-6, pl. 6, figs 1-2, pl. 8, fig. 4. - (?) Košt'ák 2004: 32, fig. 6 (poor illustration). Rudolph 2014 (partim): 19, fig. 24 (specimen on right). — Breton et al. 2017: 46, fig. 3E.

Rosetten-Form B - Hofmann \& Vogel 1992: 56, pl. IV, fig. A.

Calcidelatrix anomala - Plewes 1996: 189, pl. 33 fig. 8, pl. 35, figs 1-8.

Dendrina isp. - (?) Verde 2002: 46, pl. VI, fig. D (poor illustration).

Dendrina (Calciteletrix) anomala - Girod \& Rösner 2013: 280, fig. 13.

\section{Original diagnosis}

$\mathrm{n} / \mathrm{a}$

\section{Emended diagnosis}

Main branches may curve in a sinuous fashion and in small individuals may be devoid of smaller sidebranches along some length of the curve. From these closely prostrate main axes, with usually smooth surface texture, branches divide, may form anastomoses and gradually decrease in diameter to fine pointed ends that connect to the substrate surface.

\section{Original description}

Rosetted cavity system, strongly and regularly branching. Very conspicuous for this species are strongly varying gallery diameters, unlike all other forms described herein. While the main galleries may reach $0.7 \mathrm{~mm}$ in diameter, secondary branches may reach only $0.03 \mathrm{~mm}$ in diameter. [Translated from German]
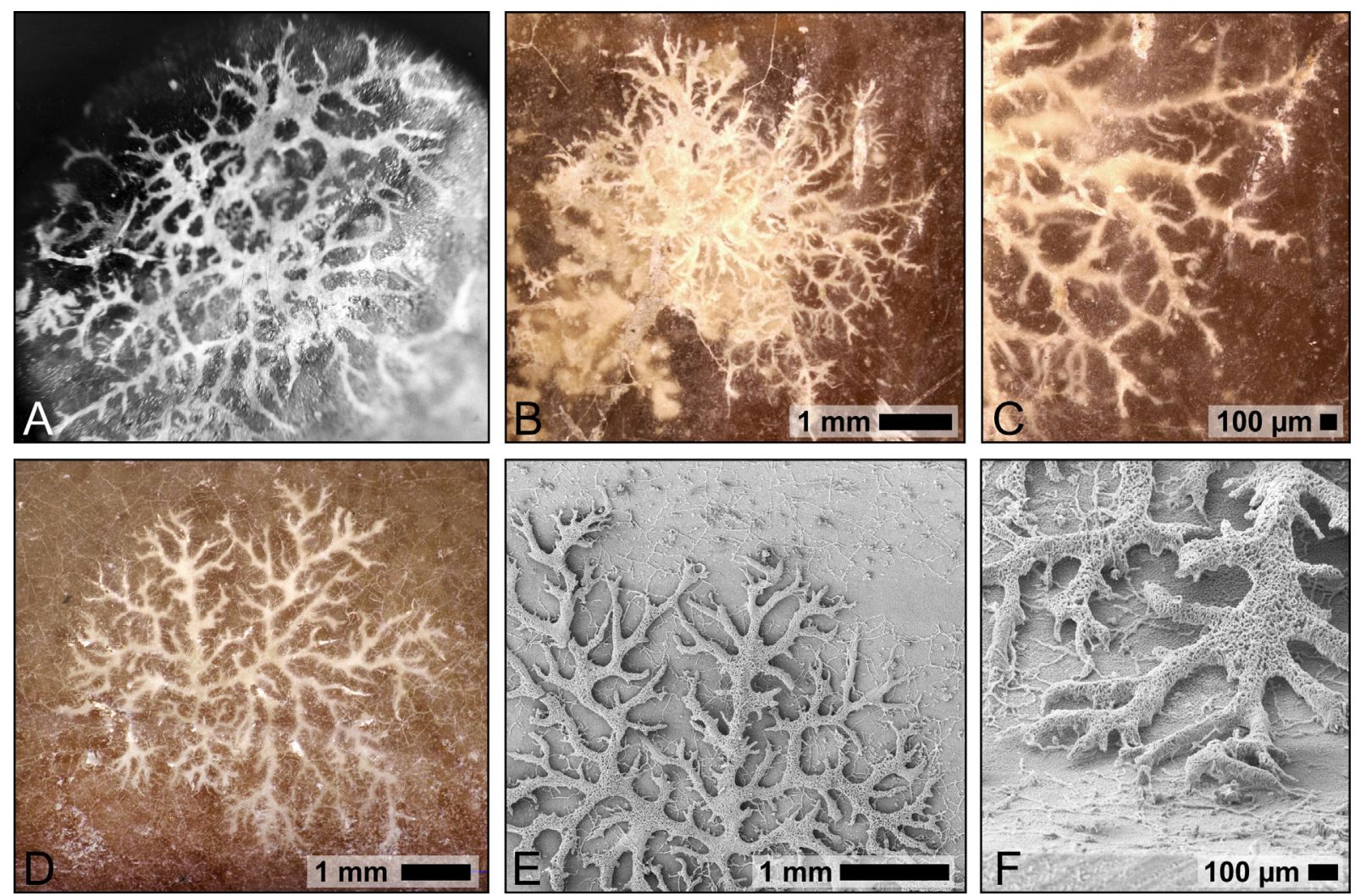

Fig. 13. Calcideletrix anomala (Mägdefrau, 1937) comb. nov. A. Original glass negative of the lost holotype from an Upper Cretaceous belemnite from Misburg, Germany. B-C. Overview and closeup of the neotype from the same type locality and horizon; the centre of the colony is partly obscured by a deeper tier of Dendrina ispp. D. A large specimen in a belemnite from the upper Campanian of Kronsmoor, Germany. E-F. SEM planar and oblique views of an epoxy cast of the same specimen. 


\section{Supplementary description}

Based on additional material, including epoxy resin casts, Plewes (1996) added the observations that the main axis is often distinctly curved, branching is polychotomous or dichotomous, the surface texture is smooth and the ends of the many lateral and peripheral branches taper to fine points which intersect with the substrate surface. She provided morphometrical data for the width of the main axes (mean $=96 \mu \mathrm{m}$; $\mathrm{n}=20 ; \mathrm{SD}=76.60$ ) and secondary branches (mean $=35 \mu \mathrm{m} ; \mathrm{n}=18 ; \mathrm{SD}=15.28$ ). Hofmann (1996) gave a size range of the trace of 2-6 mm and measured diameters of up to $180 \mu \mathrm{m}$ for the main axes and 20 to $70 \mu \mathrm{m}$ for the peripheral tunnels. In addition, he observed rare anastomoses.

\section{Type material, locality and horizon}

The holotype is preserved in a rostrum of an Actinocamax from the Upper Cretaceous of Misburg near Hannover, Germany. It used to be deposited at the collections of the Institut für Geowissenschaften und Geographie, Halle, Germany, where only the original glass negative (MLU.Mäg1937.IV.5) presently remains (Fig. 13A). Consequently, another specimen (Fig. 13B-C) within the original material of Mägdefrau from the same type horizon and locality, on the same belemnite (MLU.Mäg1937.IV.10) that carries the holotype of Dictyoporus nodosus Mägdefrau, 1937, was selected as the neotype by Plewes (1996). Since the latter designation was not a valid nomenclatural act (unpublished thesis), this neotype designation is hereby formalised.

\section{Remarks}

This ichnospecies was originally established within the ichnogenus Dendrina by Mägdefrau (1937). However, Dendrina is morphologically very distinct and the ichnospecies shows typical characters intermediate between those of Clionolithes and Calcideletrix instead. Plewes (1996) consequently placed D. anomala within Calcideletrix (without discussion or designation as comb. nov. and misspelled as Calcidelatrix). Nevertheless, this synonymisation appears practical and is followed and formalised herein. Calcideletrix anomala is the largest among the suite of ichnospecies of Calcideletrix, and is morphologically closest to the related ichnogenus Clionolithes and in particularly C. radicans. It is clearly distinguished from the latter by the lack of a distinct central node, the common presence of anastomoses of the main galleries in the central area, and by its very gradual decrease in gallery diameter.

Calcideletrix fastigata (Radtke, 1991) comb. nov.

Fig. 14

Polyactina fastigata Radtke, 1991: 89, pl. 12, figs 3-4.

Algal form B - (?) Budd \& Perkins 1980: 887, fig. 7B.

Morfotipo $\mathrm{B}_{2}$ - Mayoral 1988 (partim?): 303, fig. 1.3, pl. 1, figs 2, 4.

Morfotipo $\mathrm{B}_{3}-$ (?) Mayoral 1988: 303, fig. 1.4, pl. 1, fig. 5.

Polyactina fastigata - Wisshak 2008: 43, fig. 9A-B.

\section{Original diagnosis}

Von einem Hauptast oder einem sehr kleinen zentralen Hohlraum zweigen strahlenartig in einer Ebene Gänge auf, die sich zum distalen Ende hin verjüngen und in dünnen, z. T. sehr langen, verzweigten, rhizoidalen Ausläufern enden. Auf der der Schalenoberfläche zugewandten Seite stehen Rhizoide mit der Oberfläche in Verbindung. [Translation: From a main gallery or a very small central cavity, tunnels radiate and ramify in one plane, and taper along partly very long rhizoidal galleries towards their distal termination. Facing the substrate surface, rhizoids connect the galleries with the surface] 


\section{Original description}

The general shape of the trace varies, but follows a dendritic growth pattern. Either from a very small central cavity dichotomously branching galleries radiate, or the central cavity is developed more as an elongated main branch, from which further partly bent galleries emerge. The galleries measure 8 to $15 \mu \mathrm{m}$ in diameter (entire trace: 100 to $1150 \mu \mathrm{m}$ ) and branching points are mostly swollen (Ø 11 to $25 \mu \mathrm{m}$ ). They bifurcate in acute angles (ca $30^{\circ}$ to $50^{\circ}$ ). The transitions to the side branches often show web-like widenings. All traces show the characteristic tapering terminations that lead into bifurcating and partly very long rhizoids (Ø 0.5 to $4 \mu \mathrm{m}$ ). The latter are not restricted to the terminations but occur in the entire gallery system, facing the substrate surface ( $\varnothing$ then mostly 0.5 to $1.5 \mu \mathrm{m}$ ). They partly act as small pillars below the main galleries. In the mostly chaotically arranged rhizoids occasionally spindleshaped swellings (Ø 2 to $5 \mu \mathrm{m}$ ) can be seen. [Translated from German]

\section{Type material, locality and horizon}

The type material consists of a cast with many specimens, collectively addressed as "holotype" in the original publication, in a resin cast of a shell of Pecten O.F. Müller, 1776 from the Sophia Jakoba
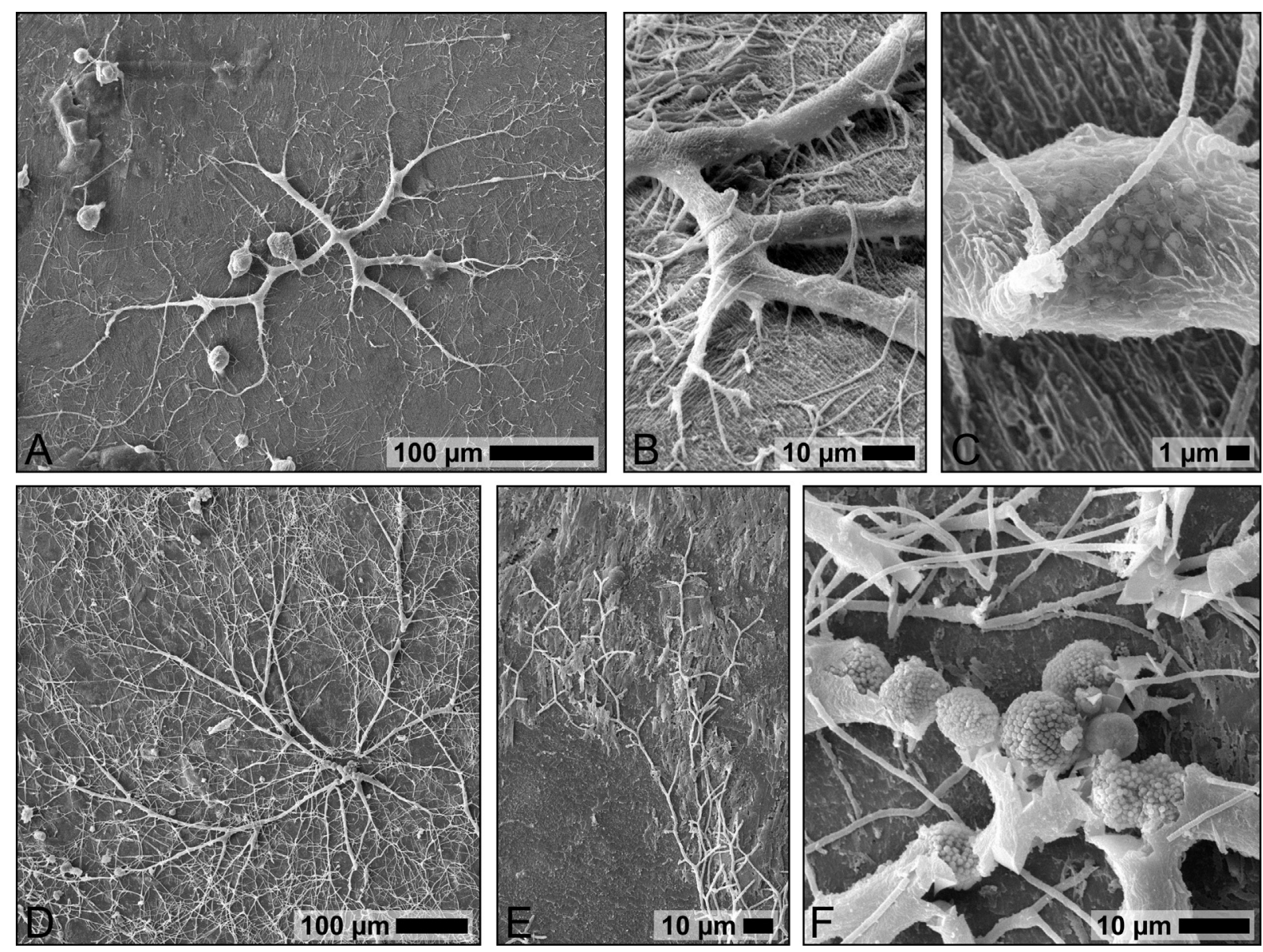

Fig. 14. Calcideletrix fastigata (Radtke, 1991) comb. nov. A-C. SEM of the lectotype (together with fungal trace Saccomorpha clava Radtke, 1991) in an epoxy cast of an Oligocene Pecten bivalve shell from the Niederrheinische Bucht, Germany. Close-up in B illustrates the fine rhizoidal connections to the substrate surface. Close-up in C shows framboidal pyrite spheres (fossil fungal spores?) embedded within the resin. D-F. Large paralectotype in a cast of an Oligocene Ostrea bivalve shell from the same locality. Close-up in E exhibits the alternating bifurcation pattern of very fine peripheral galleries. Closeup in F shows the centre of the trace with further framboidal pyrite aggregates; epoxy resin was hindered in penetrating the cavity due to calcite spar (now dissolved). 
8 II locality, Niederrheinische Bucht, Germany; Grafenberger Sand Member, Upper Oligocene. Numerous further specimens collectively addressed as "paratypes" in several casts of another Pecten shell from the same locality, and in casts of an Ostrea shell from the Sophia Jakoba 6 locality, Lower Rhine Embayment; Germany, Ratheimer Beds, Lower Oligocene. Hereby, the specimen originally illustrated by Radtke (1991: pl. 12, figs 3-4) is designated as the lectotype (Fig. 14A-C), rendering all other specimens in the type material paralectotypes (e.g., Fig. 14D-F). It is deposited at the Institut für Geowissenschaften, Goethe Universität, Frankfurt, Germany (inventory numbers: Bo 7/161 for the lectotype and paralectotypes; Bo 7/147 and Bo 7/160 for further paralectotypes).

\section{Remarks}

In the centre of one of the paralectotypes (on Bo 7/147), several framboidal pyrite aggregates were found (confirmed via EDX detection of Fe and $\mathrm{S}$ in stoichiometric correct proportions), possibly representing pyritised fungal spores (Fig. 14D, F). They were surrounded by calcite spar that was dissolved by the hydrochloric acid during the sample preparation procedure, explaining why the centre of the trace was not reached by the epoxy resin impregnation. In the case of the lectotype, several of these framboidal pyrite aggregates are embedded within the resin at points of slight swellings along the main gallery, as evidenced by a differential SEM signal when using a backscatter electron (BSE) detector (Fig. 14C).

This ichnospecies is the smallest representative of Calcideletrix. It often shows a rather rapid tapering from the generally constant diameter of the central main galleries towards the rhizoidal appendages as well as the extensive peripheral galleries. The latter often show a strict alternating bifurcation pattern, distinguishing it from the other taxa within this ichnogenus.

Originally established within the ichnogenus Polyactina, but clearly distinguished from its former sister ichnospecies Polyactina araneola (= type ichnospecies) by being a non-colonial and prostrate trace, the presence of the rhizoidal connections to the substrate surface, and the alternating bifurcation pattern of the peripheral galleries.

Dictyoporus Mägdefrau, 1937

Cicatricula Palmer \& Palmer, 1977: 186.

Dendrorete Tavernier et al., 1992: 304.

\section{Type ichnospecies}

Dictyoporus nodosus Mägdefrau, 1937, by monotypy.

\section{Original diagnosis}

$\mathrm{n} / \mathrm{a}$

\section{Emended diagnosis}

Radiating, reticulate system of etched channels or prostrate tubular borings at or immediately beneath the surface of calcareous substrates. High degree of anastomosis, leaving only a few peripheral branches blind ending.

\section{Original description}

Distinctly net-shaped cavity system in belemnite rostra without external opening. [Translated from German] 


\section{Remarks}

A reinvestigation of the holotype of the type species and a wealth of new material from other localities exposing Upper Cretaceous strata in northern Germany revealed a considerable morphological variability between specimens, as well as within one and the same trace of $D$. nodosus. This variability concerns the degree of anastomosis, the mesh size, and - most importantly - the occurrence and co-occurrence of shallow open channels and prostrate endolithic tunnels. While the distinction between open and closed galleries is possible in well-preserved material, it is often altered even by slight erosion or diagenetic pressure dissolution, complicating a confident discrimination. As a consequence, a morphological and ichnotaxonomical distinction of $D$. nodosus from several other ichnotaxa cannot be maintained and herein leads to a widening of the ichnogenus diagnosis and a number of synonymisations. At the ichnogenus level, this concerns the ichnogenus Cicatricula Palmer \& Palmer, 1977, which was only distinguished from Dictyoporus by its preservation as open channels, while its most conspicuous feature, the high degree of anastomosis, was not part of the original ichnogenus diagnosis. However, that feature in particular and the flat and widened branching points strongly support an inclusion within Dictyoporus. Elias (1980) made the case that both Cicatricula and Calcideletrix should be considered as synonyms of Dictyoporus that run at and below the substrate surface, respectively. However, Calcideletrix is clearly distinguished from Dictyoporus based on other, more distinct, morphological characters (i.e., almost complete lack of anastomoses, regular rhizoidal connections to substrate surface, etc.), and a synonymisation with Dictyoporus is thus not recommended. Another potential junior synonym is Repentella Müller, 1968, the description and illustrations of which suggest the presence of tunnels with anastomoses similar to those in Dictyoporus. However, reinvestigation of the type material clearly showed that they are merely moulds of epiliths and not trace fossils. The morphology of Dendrorete Tavernier, Campbell \& Golubic, 1992 also corresponds closely to that of Dictyoporus and the former ichnogenus is herein regarded as another junior synonym. Its type ichnospecies is the only ichnospecies that is morphologically clearly distinct from $D$. nodosus and is thus retained as a new combination.

Dictyoporus nodosus Mägdefrau, 1937

Fig. 15

Dictyoporus nodosus Mägdefrau, 1937: 55, pl. IV, fig. 10.

Cliona fenestralis Elias, 1957: 383, pl. 40, fig. 2.

Cicatricula retiformis Palmer \& Palmer, 1977: 185, fig. 6.

Dictyoporus garsonensis Elias, 1980: 273, figs 1-3.

Dictyoporus nodosus - Häntzschel 1962: W230, fig. 144-5 (reproduced from Mägdefrau 1937); 1975: W127, fig. 78-5 (reproduced from Mägdefrau 1937). — (?) Pugaczewska 1965: 75, pl. I, fig. 1; 1970: 427, pl. I, fig. 1. — Nadjin 1969: 155, pl. IV, fig. 10 (reproduced from Mägdefrau 1937). — Plewes 1996: 191, pl. 36, figs 1-7. — Buatois et al. 2017: 161, fig. 75D (holotype). - Breton et al. 2017: 46, fig. 3D.

Without name - Lindström 1979: 154, fig. 2A-C. — Girod \& Rösner 2013: 282, fig. 15c.

Calcideletrix breviramosa - Ghare 1982: 132, pl. 1, fig. 6. - (?) Košt'ák 2004: 32, fig. 12 (poor illustration).

Calcidelatrix flexuosa - Plewes 1996 (partim): 186, pl. 33, figs 3, 5, pl. 34, figs 5-6. — (?) Košt’ák 2004: 32, fig. 11 (poor illustration).

Dendroid-Form A - Bundschuh 2000: 63, pl. 8, figs 5-8.

Dendroid-Form C - Bundschuh 2000: 66, pl. 9, figs 3-5.

\section{Original diagnosis}

$\mathrm{n} / \mathrm{a}$ 

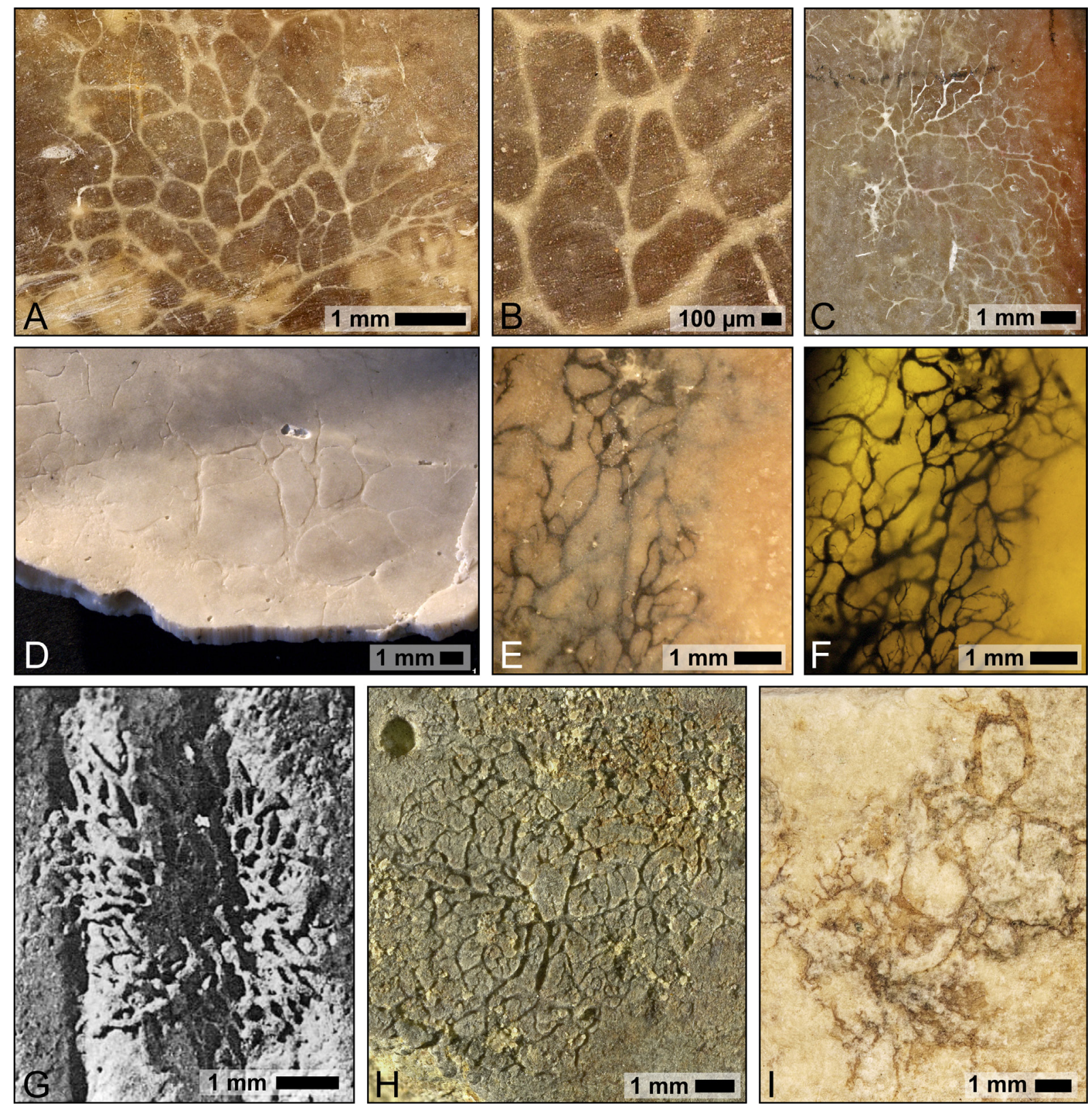

Fig. 15. Dictyoporus nodosus Mägdefrau, 1937. A-B. Overview and close-up of the holotype in an Upper Cretaceous belemnite from Misburg, Germany. C. Specimen with lower degree of anastomosis, but better defined centre; same belemnite as holotype of Calcideletrix flexuosa Mägdefrau, 1937. D. Large specimen in a shell of the bivalve Inoceramus Sowerby, 1814 from the upper Campanian of Kronsmoor, Germany, showing a combination of open channels and endolithic tunnels. E-F. Incipient and transmission light micrographs of a pyritised specimen in an aptychus from the lower Campanian of Höver, Germany, showing surficial channels, a deeper tier of endolithic tunnels and variability in tunnel diameter. G. Holotype of junior synonym Cliona fenestralis Elias, 1957, preserved as natural cast in a Late Mississippian brachiopod (currently lost; reproduced from Elias 1967: pl. 40, fig. 2; scale bar derived from original description). H. Holotype of junior synonym Cicatricula retiformis Palmer \& Palmer, 1977 on a slab of Ordovician hardground, displaying readily anastomosing channels with a decrease in mesh size towards the periphery. I. Holotype of junior synonym Dictyoporus garsonensis Elias, 1980, preserved in an Upper Ordovician rugose coral. 


\section{Emended diagnosis}

Overall shape as well as gallery diameter and mesh-size varies but generally decreases towards the periphery of the trace. Branching points flattened parallel to the substrate surface and with rounded outline. Peripheral branches taper to pointed ends and have a jagged appearance. Galleries either developed as open channels and/or prostrate tunnels with few rhizoidal connections to the substrate surface.

\section{Original description}

Channels $0.06-0.08 \mathrm{~mm}$ in diameter, with swellings at branching or crossing points. [Translated from German]

\section{Supplementary description}

The morphology of this ichnospecies is quite variable and partly dependent on the ontogeny of the trace or the type of substrate. All of this variability is evident in the Upper Cretaceous material alone and concerns the overall shape of the traces, ranging from radial symmetrical and circular to oval specimens (Fig. 15C) to more irregular outlines with little discernible centre (Fig. 15A-B, D-F). It also concerns the degree and the mesh size of the anastomoses, with a general trend towards smaller size at the periphery of the trace, which often goes along with a decrease in gallery diameter (Fig. 15C-F). Most conspicuously, the variability is expressed in the preservation of the galleries as open surficial etchings vs true endolithic tunnels, including the combination of both orientations within one and the same trace, either laterally grading into each other (Fig. 15D) or developed as multiple tiers (Fig. 15E-F). Published data on the diameter of the trace range from 0.5 to $14 \mathrm{~mm}$ (Elias 1957, for junior synonym Cliona fenestralis; Palmer \& Palmer 1977, for junior synonym Cicatricula retiformis; Bundschuh 2000 for synonyms 'Dendroid-Form A' and 'Dendroid-Form D'), and tunnel diameters were specified to range from 60 to $80 \mu \mathrm{m}$ (Mägdefrau 1937; Plewes 1996).

\section{Type material, locality and horizon}

The holotype (Fig. 15A-B) is preserved in a Belemnitella mucronata (Schlotheim, 1813) rostrum from the Upper Cretaceous of Misburg near Hannover, Germany, deposited in the collections of the Institut für Geowissenschaften und Geographie, Halle, Germany (MLU.Mäg1937.IV.10).

\section{Remarks}

As noted above, the considerable morphological range of $D$. nodosus questions the validity of a number of other ichnotaxa characterised by strongly anastomosing networks of channels or shallow tunnels. As a consequence, a number of ichnospecies are herein lumped within D. nodosus as subjective junior synonyms. This concerns Cliona fenestralis, established by Elias (1957) as a sponge biotaxon, based on a single natural cast in a Carboniferous brachiopod. The holotype is currently lost but the morphological resemblance to $D$. nodosus is evident from the original illustration alone (reproduced in Fig. 15G). The second junior synonym is Cicatricula retiformis, reported by Palmer \& Palmer (1977) from an Ordovician hardground (Fig. 15H). Its preservation as an anastomosing network of open channels does not merit retaining a separate ichnospecies, let alone ichnogenus. The third junior synonym is Dictyoporus garsonensis, established by Elias (1980) based on traces in an Upper Ordovician rugose solitary coral and characterised as a combination of larger, surficial to epilithic anastomoses grading into smaller, endolithic tunnels in the periphery of the trace (Fig. 15I). Reinvestigation of the holotype showed that the diagenetic alteration and state of preservation render such a distinction problematic, and the body fossil preservation of epilithic algae thalli (according to Elias the part of the trace shown at the top of Fig. 15I) is herein questioned. These features more likely present mineralised infills of either shallow etched channels or exposed parts of endolithic tunnels, and both of these features are well within the morphological range of $D$. nodosus. The trace also appears to be very common in Silurian skeletal 
carbonates, such as reported by Bundschuh (2000) under the informal names Dendroid-Form A and C, with the two forms again illustrating the morphological variability of $D$. nodosus, which agrees with the appearance of this trace in epoxy casts of Cretaceous specimens.

Dictyoporus balani (Tavernier, Campbell \& Golubic, 1992) comb. nov.

Fig. 16

Dendrorete balani Tavernier, Campbell \& Golubic, 1992: 304, figs 2-3.

Without name - Rooney \& Perkins 1972: 1146, figs 12, 14.

Dendrorete balani - Tavernier \& Golubic 1993: 409, fig. 2. — (?) Blissett \& Pickerill 2007: 82, fig. 3 (dubious illustration).

\section{Original diagnosis}

Shallow, radiating to prostrate boring networks spread beneath the shell surface of the barnacle Balanus sp. Individual systems range from 1 to $4 \mathrm{~mm}$ in diameter and penetrate 100-200 $\mu \mathrm{m}$ into the shell. They consist of tubular, branched and anastomosing tunnels. The tunnels spread immediately below, and parallel to the substrate surface, they branch repeatedly and fuse at contact, forming twodimensional networks. At the periphery of the system, long and shallow "exploratory" tunnels penetrate the substrate and branch. Branching is subdichotomous or lateral, diverging at angles of $82^{\circ} \pm 19^{\circ}(50)$. The branches behind the expansion front arch deeper into the substrate and anastomose. The average mesh size of the resulting reticulum is $257 \pm 63$ (16) $\mu \mathrm{m}$. Pointed lateral branches that originate along the interconnecting tunnels give the network a spiny appearance, and ultimately subdivide the network. As a consequence, the density of the net in the older parts increases by secondary branching (mesh size $103 \pm 28(26) \mu \mathrm{m})$. In addition, the tunnels send out at intervals finer tubular connections $(10 \pm 2.5$ $(18) \mu \mathrm{m})$ to the substrate surface. The main tunnels are circular or ellipsoidal in cross-section, with the longer axis oriented upright, i.e., perpendicular to the substrate surface. They are 20-50 $\mu \mathrm{m}$ in diameter $(\mathrm{M} \pm \mathrm{s}(\mathrm{n})=35.5 \pm 8.5(78) \mu \mathrm{m})$, appear knobby, and are occasionally widened at branch points. The boring starts from a single point of entry and spreads initially in a radiating fashion. When cast in resin, these young diverging tunnels resemble the surface roots of some tropical trees. In later stages the network becomes prostrate, and the radiating pattern is masked by anastomosing cross-connections.
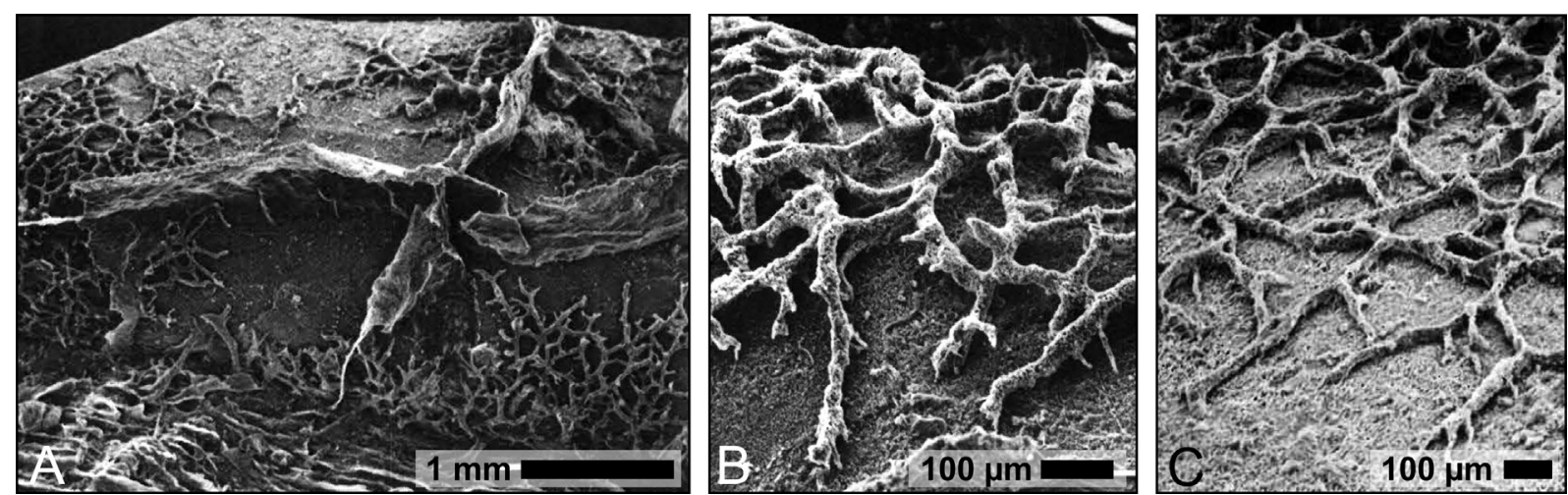

Fig. 16. Dictyoporus balani (Tavernier, Campbell \& Golubic, 1992) comb. nov. A. SEM of holotype (lower right corner) in an epoxy cast of a Pliocene Balanus shell (reproduced from Tavernier et al. 1992: fig. 1A). B. Close-up of holotype (reproduced from Tavernier et al. 1992: fig. 1D). C. Prostrate peripheral reticulum with rhizoidal connections to the substrate surface (reproduced from Tavernier $e t$ al. 1992: fig. 2B). 
Thus, a mature boring system of Dendrorete balani is organized in three concentric zones. The peripheral (youngest) one is the zone of lateral spreading of the boring system with straight, shallow "exploratory" tunnels. In the second zone behind, these tunnels interconnect to form a flat horizontal reticulum. Branches oriented toward the interior that form deeper arches are more common in the third (oldest) zone resulting in a three-dimensional reticulum.

\section{Emended diagnosis}

Tunnels branch sub-dichotomously or laterally, occasionally widened at branch points, circular or ellipsoidal in cross-section, with the longer axis oriented perpendicular to the substrate surface, sending out finer tubular connections at intervals to the substrate surface. A mature boring system is organised in three concentric zones, a peripheral zone of lateral spreading with straight, shallow tunnels, a second zone behind with tunnels interconnecting to form a prostrate reticulum and branches more commonly forming deeper arches of a three-dimensional reticulum in the central zone.

\section{Original description}

$\mathrm{n} / \mathrm{a}$, but see detailed original diagnosis.

\section{Type material, locality and horizon}

Holotype (Fig. 16A-B) in resin-cast of a Balanus fragment from the Purisima Formation, Pliocene, sampled at the base of a sea cliff at Capitola State Beach, Capitola, CA, USA. It is supposedly deposited in the Harvard University Paleobotanical Collection (HU-62706), but is at present not traceable in this collection.

\section{Remarks}

Originally established within the ichnogenus Dendrorete, which is herein regarded as a junior synonym of Dictyoporus (see above).

Dictyoporus balani is clearly distinguished from D. nodosus by the more distinct ontogenetic zones, including deeper arches in the central (oldest) part of the trace, a higher number of rhizoidal connections to the substrate surface, a generally smaller trace and tunnel diameter, and by its mesh-size decreasing in the centre due to secondary interconnecting tunnels. In contrast to D. nodosus, this ichnospecies always consists of endolithic tunnels only.

Abeliella Mägdefrau, 1937

\section{Type ichnospecies}

Abeliella riccioides Mägdefrau, 1937, by subsequent designation in Häntzschel (1962).

\section{Original diagnosis}

$\mathrm{n} / \mathrm{a}$

\section{Emended diagnosis}

Strictly dichotomously branching boring system, running at or closely below the surface of osteic substrates. From a single point of entry, galleries of nearly constant diameter ramify without anastomosis and may show slight lateral widening towards the periphery of the trace.

\section{Original description}

Strictly dichotomously ramifying cavity system with an entrance at its "base". Diameter of tunnels 4-8 $\mu \mathrm{m}$. [Translated from German] 


\section{Remarks}

Despite their minute size, these traces were already illustrated in detail in the mid- $19^{\text {th }}$ century by Rose (1855) and Kölliker (1860) in transparent fossil fish scales (see reproduction of original figures in Fig. 17A-B). Mägdefrau (1937) established two ichnospecies, A. riccioides and A. procera, both from fossil fish scales. Häntzschel (1975), in the second edition of the trace fossil volume of the Treatise on Invertebrate Paleontology, claimed that it was him in the first edition of the trace fossil volume of the Treatise (Häntzschel 1962) who should be regarded as the first author of Abeliella, based on the assumption that the original description by Mägdefrau is to be considered a nomen nudum due to the missing designation of a type ichnospecies. However, the designation of a type ichnospecies only became a requirement in 2000 with the $4^{\text {th }}$ edition of the ICZN, and Mägdefrau's original description is thus readily valid.

Unlike all other dendrinids, A. riccioides and A. procera are developed in phosphatic fossil fish scales, teeth, and jaw or skull elements, thus representing the only dendrinids observed to date in an osteic and not a calcareous substrate. A third ichnospecies, A. bellafurca Radtke et al., 2010, was established from calcareous skeletal substrate. However, the principal substrate type is considered an important ichnotaxobase at the ichnogeneric level (e.g., Bertling et al. 2006; Höpner \& Bertling 2017); thus, this conspicuous ichnospecies is better accommodated in a different ichnogenus. This decision is furthermore supported by the fact that unlike the other two ichnospecies of Abeliella, A. bellafurca is not strictly prostrate, but does develop a considerable vertical expansion in the central part of mature colonies, forming bundles of radiating galleries and thus bearing a close morphological (and biological) resemblance to the cyanobacterial ichnogenus Fascichnus Radtke, 1991. Dichotomous branching is, although less pronounced, a common feature in several of the ichnospecies of Fascichnus and it thus seems most practical to transfer A. bellafurca to Fascichnus under the new combination Fascichnus bellafurcus.

Corrosion traces similar to Abeliella were described by Elsik $(1966,1971)$ in another type of substrate, the exine of fossil pollen and spores of Mississippian to Tertiary age. The latter traces have not been treated ichnotaxonomically as yet and should be grouped within a separate ichnogenus when acknowledging the substrate type as a primary ichnotaxobase (see above).

Abeliella riccioides Mägdefrau, 1937

Fig. 17

Abeliella riccioides Mägdefrau, 1937: 60, text-fig. 1, pl. V, fig. 1.

Without name - Rose 1855: 9, pl. I, fig. 5a-d. — Kölliker 1860: 228, pl. XVI, fig. 14. - Seward 1898: 127, fig. 27A (reproduced from Rose 1855). - Siverson 1993: 3, pl. 4, figs 1-2, 9-12.

Abeliella riccioides - Häntzschel 1962: W228, fig. 142-7 (reproduced from Mägdefrau 1937); 1975:

W123, fig. 77-6 (reproduced from Mägdefrau 1937). — Underwood et al. 1999: 71, fig. 2a-d. — Buatois et al. 2017: 161, fig. 75G.

non Abiella sp. - Kutscher 1972: 27, figs 9-10 (= Talpina ramosa).

\section{Original diagnosis}

$\mathrm{n} / \mathrm{a}$ 


\section{Emended diagnosis}

Distinctly regular and bilateral symmetrical ramification pattern, strictly dichotomous and prostrate, with angle of bifurcations decreasing towards the periphery of the trace. Nearly constant tunnel diameter and only weakly widened gallery terminations.

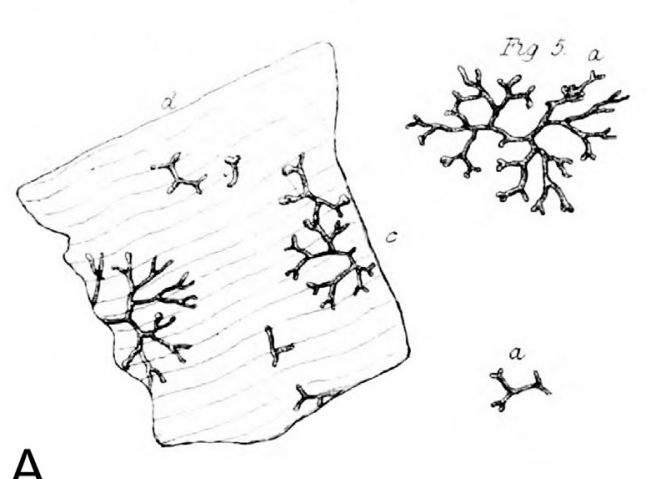

A
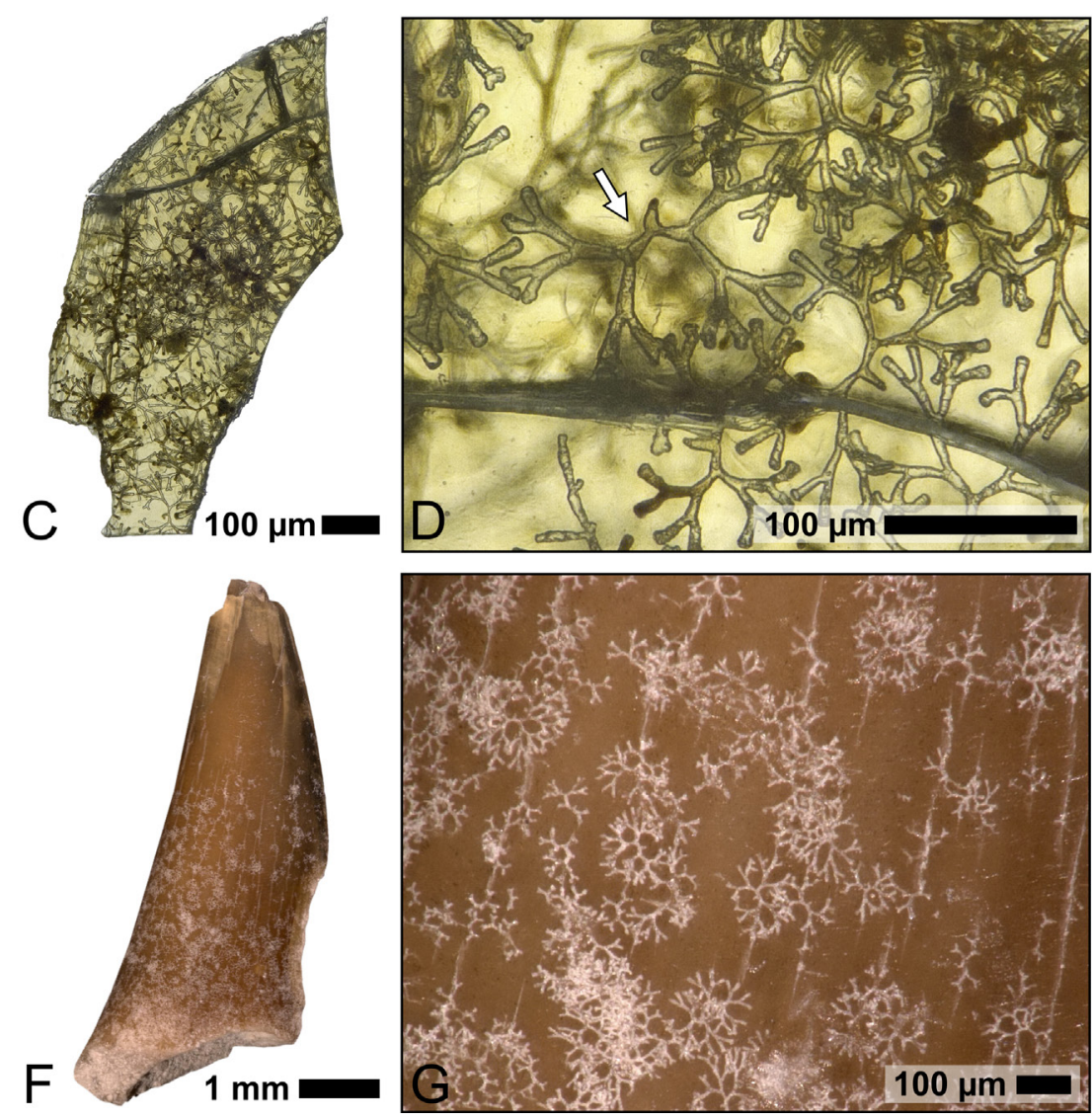
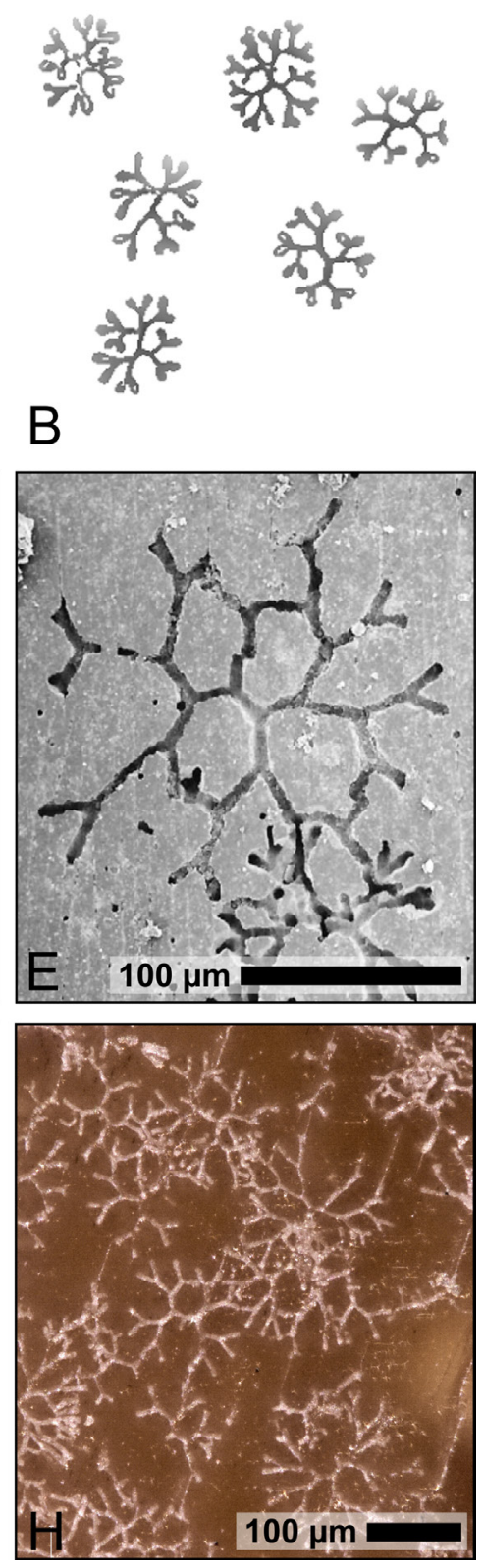

Fig. 17. Abeliella riccioides Mägdefrau, 1937. A-B. Early illustrations of this trace fossil by Rose (1855) and Kölliker (1860) based on observations of Cretaceous fish scales (reproduced from Rose 1855: pl. I, fig. 5 and Kölliker 1860: pl. XVI, fig. 14). C. Lectotype sample showing numerous specimens in a transparent Oligocene fish scale. D. Close-up of lectotype (arrow) and several paralectotypes, illustrating near-perfect bilateral symmetry of the traces. E. Surface SEM of a Cretaceous echodont tooth, showing the avoidance of tunnels as opposed to true anastomosis (reproduced from Underwood 1999: fig. 2a). F-H. Overview and close-ups of an unidentified Cretaceous fish tooth from the lower Campanian of Höver, Germany, illustrating typical increase in abundance towards the base. 


\section{Original description}

In fossil fish scales, already Kölliker (1860) observed this very delicate and regular boring system, for which he holds a fungus responsible. These are star-shaped cavity systems (ca $0.25 \mathrm{~mm}$ in diameter) with a strictly dichotomous branching pattern. The peripheral terminations are weakly widened. Access to the tunnel system, which is oriented parallel to the surface in the interior of the scales, is located in the centre of the star. [Translated from German]

\section{Supplementary description}

Underwood et al. (1999) added the following observations and morphometrical data: "These borings have a distinctive radial pattern, with regular dichotomous bifurcations. The central point of the boring network is usually just below the surface of the substrate. Two, or more rarely three, initial branches contact the surface of the bone and thereafter stay as surface borings. The borings are either round or flattened in cross section and between 3 and $7 \mu \mathrm{m}$ across, retaining a constant width throughout the network. These borings bifurcate at intervals of 20 to $40 \mu \mathrm{m}$, with each branch dichotomously bifurcating at a similar distance, giving a very regular pattern. On a flat substrate, the proximal bifurcations enclose angles of between 90 and 120 degrees, although the angle between the more distal branches of the boring tends to be more acute, down to about 30 degrees." The size of the traces was measured in the holotype and from figures in Kölliker (1860) and Underwood et al. (1999) to range from 0.1 to $0.5 \mathrm{~mm}$.

\section{Type material, locality and horizon}

Traces in fish scale from the Oligocene of Salbe, Germany, deposited in the collections of the Institut für Geowissenschaften und Geographie, Halle, Germany (MLU.Mäg1937.V.1). Because the fish scale contains numerous individuals of $A$. riccioides (syntypes), the complete and readily typical specimen shown in Fig. 17D (arrow) is hereby designated as the lectotype.

\section{Abeliella procera Mägdefrau, 1937}

Fig. 18

Abeliella procera Mägdefrau, 1937: 61, pl. V, fig. 2.

\section{Original diagnosis}

$\mathrm{n} / \mathrm{a}$
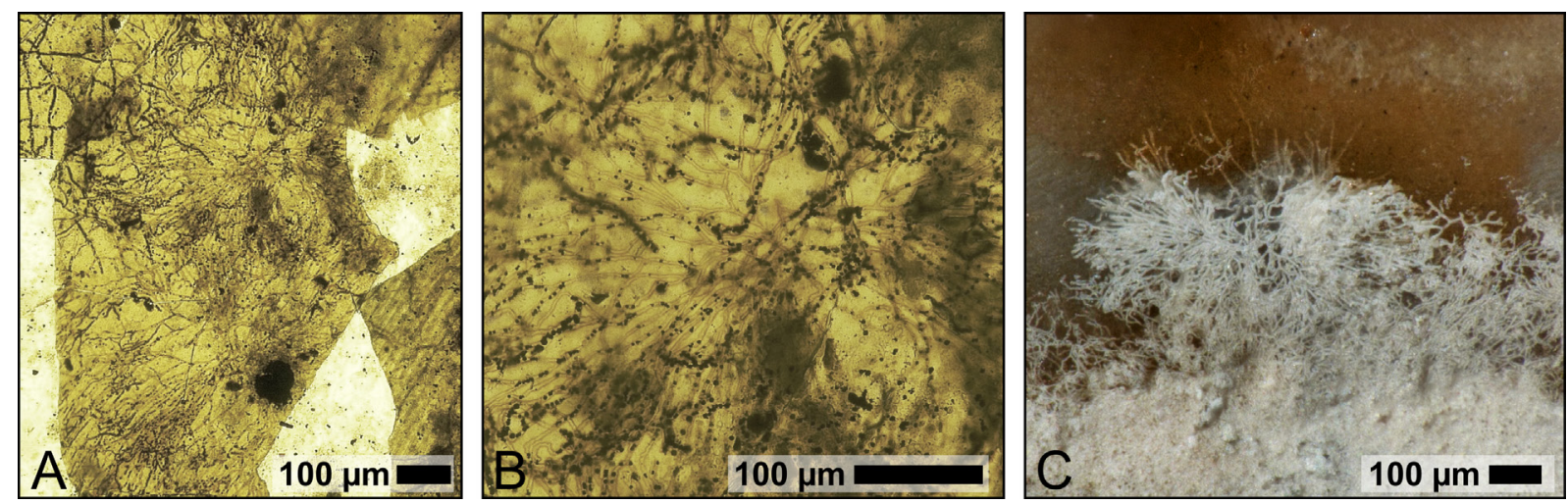

Fig. 18. Abeliella procera Mägdefrau, 1937. A. Two specimens in the lectotype sample, a transparent Oligocene fish scale. B. Close-up of lectotype illustrating details of the dichotomous bifurcation pattern in the central part of the larger (upper) specimen in A. Note the spherical aggregates (fossil spores?) filling part of the empty tunnels. C. Large specimen, together with a small A. riccioides to the right, in a Hexanthus sp. fish tooth from the lower Maastrichtian of Rügen, Germany. 


\section{Emended diagnosis}

Dichotomous ramification in acute angles and with long internodes. Tunnels of constant diameter and slightly meandering course.

\section{Original description}

Entire cavity system ca $0.5 \mathrm{~mm}$ in diameter. Tunnels weaker, with slightly meandering course, distance between bifurcations larger, branching angle smaller, and thus overall appearance more slender compared to $A$. riccioides. [Translated from German]

\section{Type material, locality and horizon}

Traces in fish scale from the Oligocene Septarienton of Eöthen, Germany, deposited in the collections of the Institut für Geowissenschaften und Geographie, Halle, Germany (MLU.Mäg1937.V.2). Because the scale contains several specimens of A. procera (syntypes), the most complete one (Fig. 18B) is hereby designated as the lectotype, which is in accordance with the original figure (Mägdefrau 1937: pl. V, fig. 2).

\section{Remarks}

This ichnospecies is distinguished from $A$. riccioides by its significantly longer internodes, a slightly meandering course of the tunnels, and more acute branching angles.

Nododendrina Vogel, Golubic \& Brett, 1987

Hyellomorpha Vogel et al., 1987: 275.

Semidendrina Bromley et al., 2007: 528.

\section{Type ichnospecies}

Nododendrina nodosa Vogel, Golubic \& Brett, 1987, by original designation.

\section{Original diagnosis}

Prostrate, rosette-shaped boring system with an enlarged node (pit) in the central area.

\section{Emended diagnosis}

Rosette-shaped boring system in calcareous skeletal substrates with one or more largely prostrate plexuses of branching and anastomosing galleries emerging from an often vertically oriented globular node below the point of entry, and connected to the substrate surface via numerous small apertures.

\section{Remarks}

Nododendrina was erected by Vogel et al. (1987) on the basis of considering both Clionolithes Clarke, 1908 and Olkenbachia Solle, 1938, and all their original ichnospecies, as nomina dubia due to the presumably inadequate preservation of the type material and the poor original illustrations. Together with Platydendrina and Ramodendrina, the new ichnogenus was proposed as a replacement ichnogenus. This procedure is not followed here and Clionolithes is considered to be valid (see above). However, Nododendrina describes a morphological group of dendrinids that is distinct from all previous ichnogenus diagnoses by addressing those rosette-shaped microborings that originate from a distinctly enlarged and vertically oriented node (as expressed also in the ichnogenus etymology), from which one or several prostrate plexuses emerge. The fourth dendrinid ichnogenus proposed by Vogel et al. (1987), Hyellomorpha, is regarded as a junior synonym since it is distinguished from Nododendrina solely on the basis of its smaller size, which is, if at all, a secondary ichnospecific ichnotaxobase. Yet another 
junior synonym is Semidendrina Bromley et al., 2007, which shares all the features of Nododendrina, except for having only one plexus emerging from the initial node, which in consequence is not located in the centre of the trace. This rather small morphological difference does not merit a separate ichnogenus.

Nododendrina is clearly distinguished from all other dendrinid ichnogenera by the presence of its distinct and often vertically oriented lateral or central node below the initial point of entry, and by an anastomosing plexus with common spiny to hairy apophyses that partly form numerous secondary connections to the substrate surface.

Nododendrina europaea (Fischer, 1875) comb. nov.

Fig. 19

Dendrina europcea Fischer, 1875: 530, pl. XVI, figs 5-6.

Hyellomorpha acuminata Tavernier \& Golubic, 1993: 409, fig. 1A (left), C-D.

Hyellomorpha magna (?) Tavernier \& Golubic, 1993: 408, fig. 1A (right), B.

Semidendrina pulchra Bromley et al., 2007: 518, figs 32.1-32.4.

Dendrina europcea - Fischer 1876: 103 (English translation of Fischer 1875).

Without name - (?) Bromley \& Surlyk 1973: 362, fig. 9A-B. — Bernard-Dumanois \& Delance 1983: 422, pl. 1, figs 1-4. - Cherchi \& Schroeder 1991: 111, figs 1-6.

Gomontia polyrhiza - (?) Boekschoten 1966: 345, fig. 3. - Higazi 1985: 146, pl. 2, fig. 1.

Morfotipo $\mathrm{B}_{5}-$ Mayoral 1988: 306, pl. 2, fig. 1, text-fig. 2.1.

J-Form C-1 - Glaub 1988: 150, fig. 2C.

Dendrina sp. - (?) Powers \& Ausich 1990: 235, Fig. 5.1.

Globodendrina monile - Plewes et al. 1993 (partim): 83, pl. 1, figs 4-8 (non fig. 1 or pl. 1, figs 1-3). Plewes 1996: 180, pl. 29, figs 3-8, pl. 40. — Kaminski 2001: 189, fig. 11. —Glaub 2004: 71, fig. 4f.

Cliona sp. 1 - Schmidt \& Freiwald 1993: 151, fig. 10a.

Semidendrina-Form - Glaub 1994: 129, pl. 11, figs 1-4.

Globodendrina - Vogel \& Marincovich 2004: 12, fig. 4/2.

Globodendrina sp. - Vogel \& Glaub 2004: 11, fig. 14.

Dendrina incomposita - (?) Košt’ák 2004: 32, fig. 7.

Semidendrina-form - Wisshak et al. 2005b: 111, fig. 14B. — Bromley 2005: 906, fig. 9. — Wisshak \& Rüggeberg 2006: 6, fig. 4F-H. - Wisshak 2006 (partim): 91, figs 24, 25F-H.

Semidendrina Form - Beuck \& Freiwald 2005: 926, fig. 5A-B.

Semidendrina pulchra - Wisshak 2008: 215, figs 1A, 2A. - Beuck 2008: 57, 72, figs 2.3.1.6A-B, 2.3.1.14A-B. - Beuck et al. 2010: 467, fig. 6A-B. - Wisshak et al. 2011: 505, fig. 7C. - Taylor et al. 2013: 234, fig. 13. - Färber et al. 2015: 10/23, fig. 7G. — Seuss et al. 2015: 509, figs 5F, 6I-J. Semidendrina-form/Semidendrina isp. - (?) Pereira et al. 2009: 335, fig. 5.3.

non ?Semidendrina pulchra - Wisshak et al. 2008: 43, fig 9C-E (= Pyrodendrina belua isp. nov.).

\section{Original diagnosis}

$\mathrm{n} / \mathrm{a}$

\section{Emended diagnosis}

From one side of a large and vertically oriented node below the point of entry, a single fan-shaped plexus of branching and anastomosing galleries emerges, connected to the substrate surface by very thin apophyses, increasing in number towards the periphery. Surface texture irregular to spiny. 


\section{Original description}

If we examine with a lens the outer surface of some coloured shells (Pecten, for example), small, opaque, irregular, lobulated whitish spots may be observed, these are Dendrina. A rounded orifice terminates a tolerably wide oblique canal, and forms a communication between the exterior and the cavity of the perforating animal. The orifice is single, and resembles the large oscula or efferent apertures of the Clionce, the lobules also are probably in communication with the ambient liquids by exceedingly delicate canals starting from their periphery, a certain number of which open at the surface of the perforated shells. [...] In thin plates of shells the perforations of the Dendrince are seen to be composed of more or less numerous irregularly branched vacuoles, which are inflated here and there, but retain throughout a pretty wide diameter. The youngest are ovoid or lageniform. Although the size of the Dendrince is variable, it is rare for an individual from the French coast (Dendrina europcea, Fisch.) to attain $0.8 \mathrm{~mm}$, generally the maximum diameter is $0.6-0.7 \mathrm{~mm}$. The large osculum measures $0.07 \mathrm{~mm}$, and the lobules vary between 0.06 and $0.08 \mathrm{~mm}$ in diameter. [...] When a Dendrina is highly magnified, a quantity of minute canals are seen to start from the periphery of the lobules and penetrate the perforated shell in all directions. These canaliculi are cylindrical, rectilinear, slightly dilated near their point of emergence, truncated at their extremities. Sometimes some are a little wider than the others, or slightly curved. Each canaliculus seems to have a distinct origin, there are no anastomoses or bifurcations [...]. Their length is from 0.03 to $0.06 \mathrm{~mm}$, and their diameter from 0.0010 to $0.0015 \mathrm{~mm}$. [Translation of original description by Fischer himself (1876)]

\section{Supplementary description}

In their detailed investigation of this trace, addressed as the junior synonym Semidendrina pulchra, Bromley et al. (2007) gave the following complementing description, based on SEM analyses of epoxy resin casts: "The dendritic boring comprises two parts: a single, main chamber (c. 50-150 $\mu \mathrm{m}$ wide) that gives issue to a plexus of finer, branching and anastomosing galleries. The main chamber has a single aperture to the surface, $30-60 \mu \mathrm{m}$ wide. The main chamber is usually connected with the plexus by a single tunnel. This tunnel is either in the size range of the plexus tunnels or up to $50 \mu \mathrm{m}$ in diameter. Rarely, two or three such tunnels run parallel between the main chamber and the plexus. The shape of the main chamber is variable, ranging from globular to narrow cylindrical, including intermediate forms. Globular chambers commonly have a rather smooth surface whereas narrow cylindrical chambers are commonly heavily ornamented, having an irregular, verrucose surface sculpture with stubby protrusions. The fan-like plexus commonly spreads to cover a half circle around the main chamber, but in well-grown individuals the plexus may exceed a semicircle. The galleries of the plexus display variable diameters ranging from 15-30 $\mu \mathrm{m}$ and vary from almost non-camerate to distinctly swollen as round chambers. Their cross section is usually irregular and not circular as is common for other microborings. The plexus of galleries is generally covered with a variable density of small, hirsute, brush-like apophyses, giving it a finely spinose appearance. These apophyses are most strongly developed at the distal terminations of the galleries, i.e., especially around the perimeter of the boring, and are most densely developed on the surface of the plexus that faces the substrate surface. The plexus is thereby connected to the surface by innumerable slender apophyses having a diameter of $<1 \mu \mathrm{m}$. The plexus lies up to $10 \mu \mathrm{m}$ beneath the substrate surface, but this distance diminishes distally. Same galleries show slightly tapering ends. Galleries may fuse together, thereby changing the plexus into a flat, palmate boring. Hair-like extensions on the main chamber, where they occur, are never as long as those on the plexus galleries. In some cases the main chamber surface texture reflects the substrate ultrastructure, taking on a foreign sculpture or xenoglyph."

\section{Type material, locality and horizon}

The hereby designated neotype (= former holotype of junior synonym Semidendrina pulchra; Fig. 19C-E) is cast in epoxy from a Lopha sp. bivalve shell from Villers-sur-Mer, France; Argiles à 

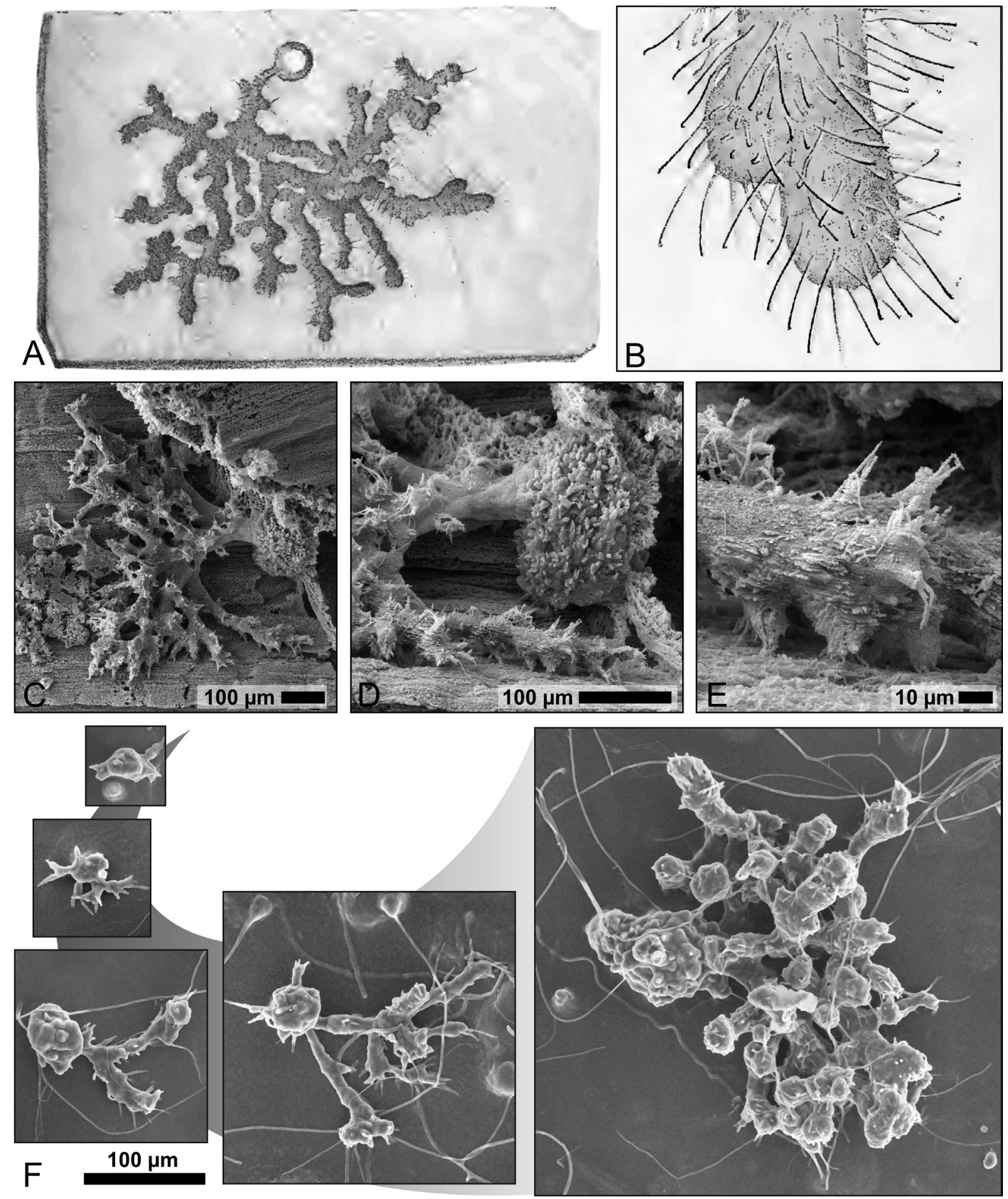

Fig. 19. Nododendrina europaea (Fischer, 1875). A-B. Original illustrations of the trace as observed in a transparent shell of the bivalve Pecten opercularis (Linnaeus, 1758) from the Gulf of Gascogne, France (reproduced from Fischer 1875: pl. XVI, figs 5-6; no scale). C-E. SEM overview and close-up of the neotype (= holotype of the junior synonym Semidendrina pulchra Bromley et al., 2007) in an epoxy cast of an Upper Jurassic Lopha shell from Villers-sur-Mer, France. F. SEM of an ontogenetic series as recorded in an epoxy cast of a bivalve shell that was exposed for two years at a depth of $15 \mathrm{~m}$ in the Kosterfjord, Sweden (modified from Wisshak 2006). 
Lopha gregarea, Oxfordian, Upper Jurassic. Deposited at the Institut für Geowissenschaften, GoetheUniversität, Frankfurt, Germany (Bo 13/159).

\section{Remarks}

Since its original description by Fischer (1875) (Fig. 19A-B), this very common dendrinid has been addressed by various formal and informal bio- and ichnotaxa, including several junior synonyms, such as Globodendrina monile, Hyellomorpha acuminata, Hyellomorpha magna (? junior synonym or nomen dubium) and Semidendrina pulchra (see list of synonymies above). Even though Fischer based Dendrina europaea on recent material and did not designate type material, this does not preclude the availability for ichnotaxa established prior to 1931, according to ICZN rules, and nor does the incorrect original spelling of the ichnospecies name europcea, which includes a ligature herein corrected to read europaea. Based on its diagnostic characters this trace is herein included in the ichnogenus Nododendrina. Complementing Fischer's detailed original description and illustration, an ichnospecies diagnosis is provided and the holotype of the now rejected junior synonym Semidendrina pulchra is designated as the fossil neotype for $N$. europaea.

The ichnotaxon vs biotaxon status of Globodendrina monile Plewes et al., 1993 is problematic since in its original description, both the boring and an agglutinated chimney around the main point of entry, interpreted as agglutinating part of a foraminiferan, was described. Most authors, e.g., Bromley et al. (2007) and Kaminski (2001), consequently consider G. monile as a foraminiferan body fossil in accordance with the original description within the foraminiferan order Astrorhizidae by Plewes et al. (1993).

The development of the plexus on only one side of the main node is a very characteristic feature, which distinguishes $N$. europaea from the other ichnospecies of Nododendrina. Its average size ranges between that of the usually smaller $N$. incomposita and the larger $N$. nodosa.

Nododendrina incomposita (Mägdefrau, 1937) comb. nov.

Fig. 20

Dendrina incomposita Mägdefrau, 1937: 56, pl. IV, fig. 2.

Dendrina minor Mägdefrau, 1937: 56, pl. IV, fig. 3.

Hyellomorpha microdendritica Vogel et al., 1987: 275, fig. 8.

Dendrina incomposita - Nadjin 1969: 138, pl. IV, fig. 2 (reproduced from Mägdefrau 1937).

Dendrina minor - Nadjin 1969: 138, pl. IV, fig. 3 (reproduced from Mägdefrau 1937).

Hyellomorpha - Vogel 1987: fig. 7.

Hyellomorpha microdendritica - Schnick 1992: 112, pl. 1-2.

Globodendrina monile - Plewes 1993 et al. (partim?): fig. 1B.

\section{Original diagnosis}

$\mathrm{n} / \mathrm{a}$

\section{Emended diagnosis}

Prostrate branches diverge from a small and irregularly shaped central node, ramify at various angles, and exhibit an irregular surface texture. Density of branching varies and anastomosis or complete fusion is common. 
WISSHAK M., Revision of the ichnofamily Dendrinidae

\section{Original description}

Cavity system 0.18 to $0.3 \mathrm{~mm}$ in total diameter, with ramifications less regular than in D. belemniticola. [Translated from German]

\section{Supplementary description}

Vogel et al. (1987) gave the following detailed description in their diagnosis of the junior synonym Hyellomorpha microdendritica from the Devonian: "Rosette-shaped, repeatedly branched systems, up to $0.5 \mathrm{~mm}(0.24 \pm 0.078$ [49]). Branches diverge radially, parallel to and immediately beneath the substrate surface, from a small central node (at the presumed point of entry). Anastomoses are common. The central node, approximately isodiametric 20-80 $\mu \mathrm{m}(50.26 \pm 19.8$ [16]) in diameter, represents the deepest penetrating part of the system. Branches diverge in straight line at angles ranging from $50^{\circ}$ to
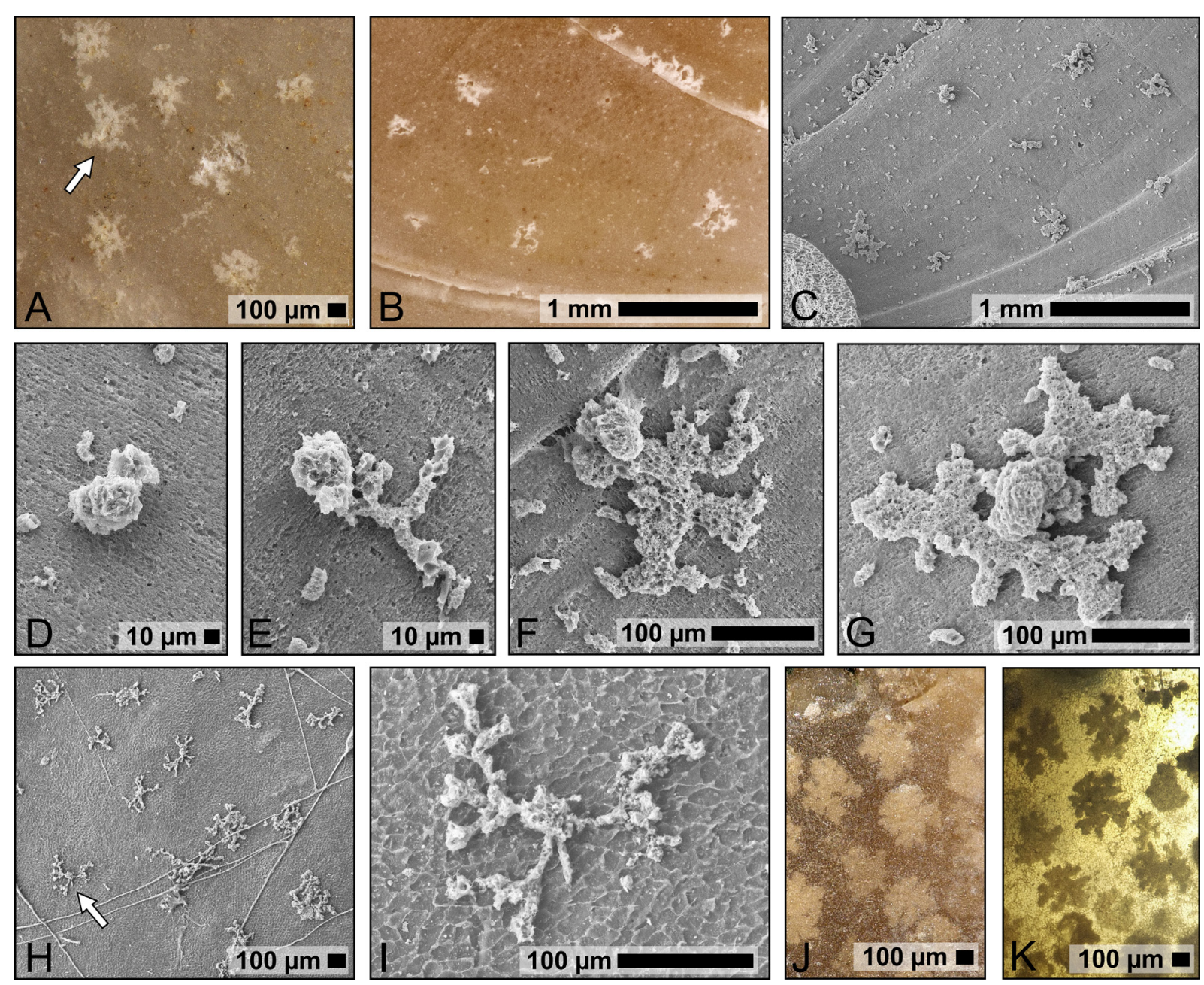

Fig. 20. Nododendrina incomposita (Mägdefrau, 1937) comb. nov. A. Lectotype (arrow) and several paralectotypes in a brachiopod shell from the upper Maastrichtian of Rügen, Germany. B. Topotypic shell of the brachiopod Chatwinothyris Sahni, 1925 with several specimens in various ontogenetic stages. C. Mirror-symmetrical SEM image of epoxy cast of the same shell. D-G. SEM close-ups of various specimens from the same shell, illustrating an ontogenetic series. H-I. Cluster of traces and close-up of holotype of junior synonym Hyellomorpha microdendritica Vogel et al., 1987, in a cast of the brachiopod Mediospirifer Bublichenko, 1959 from the Devonian at Lake Erie, New York, USA. $\mathbf{J}-\mathbf{K}$. Reflective and transmitted light micrographs of syntypes of the junior synonym Dendrina minor Mägdefrau, 1937 in an Ordovician trilobite fragment from erratics found near Köthen, Germany. 
$120^{\circ}(76 \pm 17$ [21]), or are slightly curved, or change direction abruptly. The density of branching varies within samples. Branches are circular in cross section, with a diameter of 8-19 $\mu \mathrm{m}$ (11.2 \pm 2.8 [63]), at their distal ends swollen to a diameter of 10-30 $\mu \mathrm{m}$ (17.9 \pm 5.3 [55]). The surfaces are smooth (except for substrate imprints)."

\section{Type material, locality and horizon}

Several dozen type specimens (Fig. 20A) of $N$. incomposita are preserved in a brachiopod shell from the Lower Maastrichtian (Upper Cretaceous) of Rügen, Germany, deposited in the collections of the Institut für Geowissenschaften und Geographie, Halle, Germany (MLU.Mäg1937.IV.2). One of these specimens (indicated by an arrow in Fig. 20A) is hereby selected as the lectotype, rendering the other specimens in the brachiopod paralectotypes. The lectotype is selected on the basis of it being the most typical and best preserved specimen in the type sample, and the best visible specimen in Mägdefrau's original figure (Mägdefrau 1937: pl. IV, fig. 2 upper left).

\section{Remarks}

Mägdefrau's (1937) Dendrina minor is in the size range of $N$. microdendritica and shows a very similar silhouette in reflective and transmitted light microscopy (Fig. 20J-K) rendering it a most probable junior synonym (by page priority). However, it was not possible to observe the central node in the type material and the synonymisation should thus be confirmed as soon as topotypic material is available for epoxy casting.

According to Schnick (1992: pl. 2), the trace forms in three ontogenetic stages, starting with the development of the central node, followed by the lateral development of the prostrate plexus, and consecutive fusion of the plexus around the central node. The first two phases of this ontogenetic series closely resemble the development of $N$. europaea, as illustrated (as Semidendrina pulchra) by Wisshak (2006: fig. 24) and Bromley et al. (2007: fig. 32.4). This circumstance complicates the distinction of immature $N$. microdendritica from the latter ichnospecies, which is, however, larger in diameter and its plexus always emerges to only one side from the node, whereas this limitation does not apply to $N$. microdendritica or $N$. nodosa. The latter ichnospecies is much larger and exhibits a lower degree of fusion of the prostrate galleries.

Nododendrina paleodendrica (Elias, 1957) comb. nov.

Fig. 21

Cliona paleodendrica Elias, 1957: 382, pl. 39, figs 3-10, pl. 40, fig. 1.

\section{Original diagnosis}

$\mathrm{n} / \mathrm{a}$

\section{Emended diagnosis}

From one side of an irregularly-shaped node below the point of entry, a single fan-shaped plexus of strongly branching and anastomosing galleries emerges. Galleries show pronounced swellings connected to the substrate surface by thin apophyses. Proximal plexus fused and with smooth surface texture, whereas distal plexus more irregular to spiny in texture.

\section{Original description}

This form is comparable to the excavations of the extant species of Cliona Grant, 1826, as it consists of branches coming out from the common center, each branch usually swelling into lobes, and with the lobes 
of the neighboring branches anastomosing. Parts of a few branches remain without lobate swellings, especially near their apical or distal portion. The pattern thus composed is a miniature replica of living Cliona spinosa or C. corallinoides Hancock (1849: p. 339, pl. 13, pl. 15, fig. 1) being about ten to twenty times smaller. Hancock considered width of lobes one of the important characteristics of a species; to this specific character may be added the counting of lobes per given length of a branch as a complementary characteristic. Comparison of $C$. spinosa and C. paleodendrica in regard to these two characters is as follows: width of lobes is 2 to $2.5 \mathrm{~mm}$ and $0.1 \mathrm{~mm}$, the number of lobes along a branch 5 per $10 \mathrm{~mm}$, and 5 to 7 per $1 \mathrm{~mm}$ corresponding in C. spinosa and C. paleodendrica. C. spinosa has numerous papillae that arise from the lobes, and similar papillae cover the lobes in C. paleodendrica; instead of one to three on each side of a lobe in $C$. spinosa there is a much larger number of papillae covering densely the lobes in $C$. paleodendrica. Another difference is the presence of a considerable thickening of the initial central part in C. paleodendrica, a feature neither illustrated nor mentioned in the description of C. spinosa by Hancock. The overall size of the borings does not seem to exceed $6 \mathrm{~mm}$ across in the plane of its anastomosing branches in C. paleodendrica, while it measures about $35 \mathrm{~mm}$ across or more in C. spinosa as seen in the sketch by Hancock (1849: pl. 13, fig. 5).

\section{Type material, locality and horizon}

Various syntypes (Fig. 21A) are preserved in a natural cast of a dorsal valve of a Buxtonia semicircularis brachiopod from the Late Mississippian Redoak Hollow Formation, exposed in the vicinity of the village of Milo, Carter County, Oklahoma, USA. The type material used to be deposited in the collections of the Geological Survey of Nebraska, but the empty drawer contains a note only, with the information that the collection was "scrutinised" in the 1990s; the current whereabouts of the material is unknown (Robert Diffendal, pers. comm.). Without the original material at hand, a designation of a lectotype is not feasible, and without other specimens being available, the establishment of a suitable neotype is impossible.

\section{Remarks}

The trace was originally described as a new species within the sponge biotaxon Cliona, but is actually a dendrinid boring with close affinity to Nododendrina and is thus herein transferred to the latter ichnogenus as a new combination.
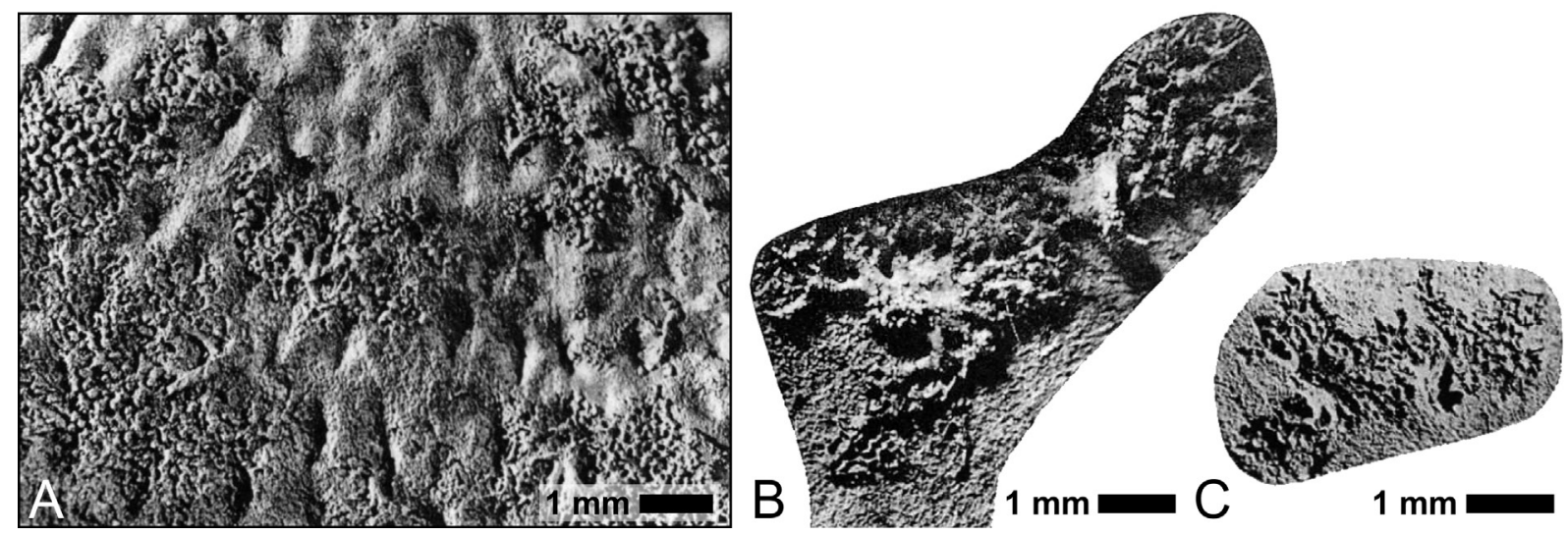

Fig. 21. Nododendrina paleodendrica (Elias, 1957). A. Original illustration of holotype (actually syntypes) in the dorsal valve of the brachiopod Buxtonia semicircularis (Sutton \& Wagner, 1931) from the Late Mississippian Redoak Hollow Formation of Oklahoma, USA (reproduced from Elias 1957: pl. 39, fig. 9). B-C. Original illustrations of further specimens in two shells of the brachiopod Chonetes Fischer de Waldheim, 1830 from the Late Mississippian Redoak Hollow Formation of Oklahoma, USA (reproduced from Elias 1957: pl. 39, figs 4 and 3, respectively). 
Nododendrina paleodendrica is considerably larger than N. europaea or N. nodosa and is primarily distinguished from these ichnospecies by more pronounced swellings along their anastomosing plexus and by a higher degree of fusion in the proximal part of the plexus, with a smooth surface texture. In contrast to $N$. nodosa, the plexus emerges from one side of the main node only, a feature that is shared by the smaller $N$. europaea and the much smaller $N$. incomposita.

Nododendrina nodosa Vogel, Golubic \& Brett, 1987

Fig. 22

Nododendrina nodosa Vogel et al., 1987: 270, fig. 4.

Hyellomorpha cheimadendritica Plewes, 1996: 184, pl. 32, figs 1-3.

Clionolithes hirsuta - Solle 1938 (partim): 162, fig. 13 (figs 2-4, 8, 11, $14=$ C. radicans, figs 5-7, $10=$

C. cervicornis, figs 9, 15, 17-18=C. pannosa).

Nododendrina - Vogel 1987: fig. 4.

Nododendrina nodosa - Buatois et al. 2017: 161, fig. 75E.

\section{Original diagnosis}

Rosette-shaped repeatedly branched systems, up to $1.5 \mathrm{~mm}$ in diameter $(1.06 \pm 0.33$ [26]). Branches diverge radially, and immediately beneath the substrate surface from a central node (presumably at the original point of entry), with frequent anastomoses. The central nodes are 75-270 $\mu \mathrm{m}$ (163 \pm 64 [10]) wide, and up to $300 \mu \mathrm{m}$ high $(207 \pm 55[10])$. The node represents the deepest penetrating part of this endolith. Radiating branches originate from the central node as high-crested ridges lowering gradually toward the periphery. The branches diverge in straight line, at angles ranging from $32^{\circ}$ to $88^{\circ}(63 \pm 15$ [63]), or are curved into U-shaped forks. The branches are high and narrow in cross section, $18-47 \mu \mathrm{m}$ $(30.74 \pm 7.56$ [100]) wide and 50-120 $\mu \mathrm{m}(87.05 \pm 19.80$ [88]) high, covered with larger and smaller spiny outgrowths. The outlines of these branches appear scalloped in both vertical and horizontal projections. Dorsal spines (i.e., those toward the interior of the brachiopod shell) end blindly, whereas the ventral ones form numerous connections with the shell surface.
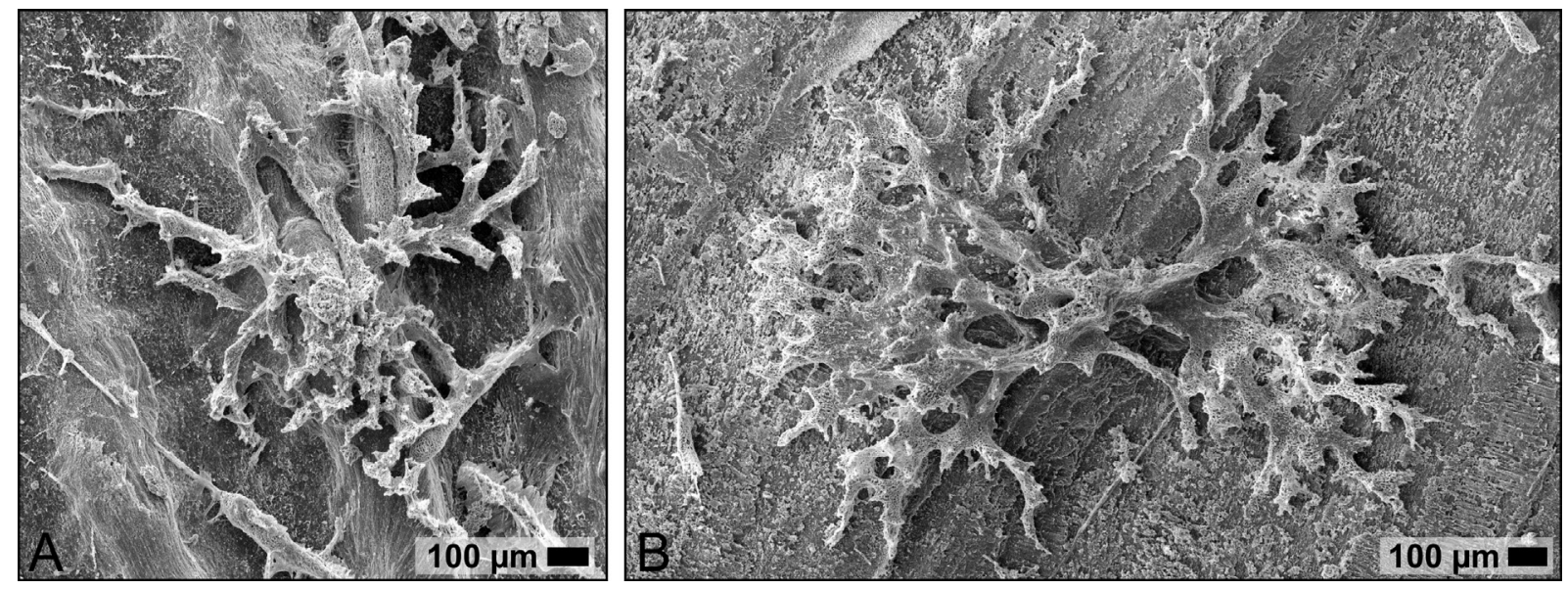

Fig. 22. Nododendrina nodosa Vogel, Golubic \& Brett, 1987. A. SEM of holotype in an epoxy cast of the brachiopod Mediospirifer Bublichenko, 1959 from the Devonian at Lake Erie, New York, USA. B. A more densely branched and anastomosing growth form in an epoxy cast of Athyris McCoy, 1844 from the Devonian at Lake Erie, New York, USA. 


\section{Emended diagnosis}

From a central node below the point of entry, prostrate branches of rosette diverge radially as highcrested ridges, lowering gradually towards the periphery. Branches diverge in straight lines, at various angles, bear frequent anastomoses, are high and narrow in cross section, and are covered with larger and smaller spiny outgrowths, with dorsal spines ending blindly, whereas the ventral ones form numerous connections with the shell surface.

\section{Original description}

$\mathrm{n} / \mathrm{a}$, but see detailed original diagnosis above.

\section{Type material, locality and horizon}

Holotype (Fig. 22A) is cast in epoxy from a Mediospirifer brachiopod shell from the Erie lakeshore bluffs S of the mouth of Eighteenmile Creek 4.0-5.5 km SW of Wanakah, New York, USA. Wanakah Member, Ludlowville Formation, Hamilton Group, Givetian, Devonian. The holotype is deposited in the Institut für Geowissenschaften, Goethe-Universität, Frankfurt, Germany (Bo 1/1).

\section{Remarks}

Plewes (1996) established Hyellomorpha cheimadendritica (a nomen nudum because her thesis was not formally published), which bears close enough morphological similarity to $N$. nodosa, albeit smaller in dimension, to be regarded as a junior synonym. Furlong \& McRoberts (2014) regard N. nodosa as a junior synonym of Clionolithes radicans, a view that is not supported here.

Nododendrina nodosa is the largest ichnospecies of Nododendrina, and is the only ichnospecies displaying high-crested galleries, the central node thus being less pronounced in its vertical extent. While $N$. europaea shows only a single plexus emerging from the main node, $N$. nodosa shows a plexus on either side of the node or galleries radiating from all around.

Pyrodendrina Tapanila, 2008

\section{Type ichnospecies}

Pyrodendrina cupra Tapanila, 2008, by original designation and monotypy.

\section{Original diagnosis}

Dendrinid boring system with shallow and deeply penetrating canals that radiate away from a central polyhedral node. Shallow canals are dominantly horizontal and may bifurcate. Deeply penetrating canals extend vertically in straight to slightly curved path and may bifurcate.

\section{Emended diagnosis}

Dendrinid boring system in calcareous skeletal substrates, with shallow and deeply penetrating canals that radiate away from a central node. Shallow canals dominantly horizontal and may bifurcate. Deeply penetrating canals extend vertically in a straight to slightly curved path and may bifurcate.

\section{Remarks}

Pyrodendrina is the only known rosetted boring to have deeply penetrating distal canals, and this feature is a primary ichnotaxobase for the ichnogenus. 


\section{Pyrodendrina cupra Tapanila, 2008}

Fig. 23

Pyrodendrina cupra Tapanila, 2008: 129, figs 3-7.

Rosette A - Tapanila 2005: 172, fig. 7.3-7.4.

Without name - (?) Bromley et al. 2007: 526, fig 32.5.

Pyrodendrina cupra - Buatois et al. 2017: 161, fig. 75F (holotype).

\section{Original diagnosis}

Rosette-shaped boring with shallow canals that bifurcate radially from a central node located below shell surface. Deep vertical canals extend radially below the central node. Canals taller than wide, with tapered terminals.

\section{Original description}

The dendrinid microborings are subdivided into three parts, which occupy successive depths within the shell. Nearest the outer shell surface, the proximal part of the microboring consists of dominantly horizontal radial canals, the middle part is a central node, and the distal part (most deeply penetrating portion) consists of dominantly vertical radial canals. The overall profile of the boring has an hourglass shape and in plan view the boring is oval in extent. The maximum diameter of the rosette is on average $445 \mu \mathrm{m}$, with a central node diameter of $105 \mu \mathrm{m}$. The maximum depth of penetration (distal-most extent) observed is $312 \mu \mathrm{m}$. The proximal part of the microboring has the greatest lateral extent. It consists of roughly a dozen primary radial canals that may bifurcate at an angle of $33-98^{\circ}$ to form secondary canals. All proximal canals are $33-50 \%$ taller than they are wide (mean width is $16 \mu \mathrm{m}$ ). The canals radiate from multiple points on the central node, roughly $50 \mu \mathrm{m}$ below the shell surface. The length of individual canals averages $140 \mu \mathrm{m}$, and these bifurcate at an average distance of $44 \mu \mathrm{m}$ away from the central node. Surface apertures of the proximal canals are most abundant away from the center of the microboring, i.e., toward the periphery of the rosette. The vertical dimension of the canals enlarges toward their connection with the central node, giving them the appearance of buttresses. The central node is polyhedral, typically having a greater horizontal (radial) dimension $(80-100 \mu \mathrm{m})$ than vertical $(50-60 \mu \mathrm{m})$. The node typically initiates roughly $50 \mu \mathrm{m}$ below the shell surface and extends to a depth of 100-150 $\mu \mathrm{m}$ before branching into the distal part. [...] The distal part of the microboring consists of canals that radiate distally from the apices of the polyhedral central node. Up to 9 distal canals are observed in one rosette. The canals extend in a dominantly vertical path, but may form broad curves
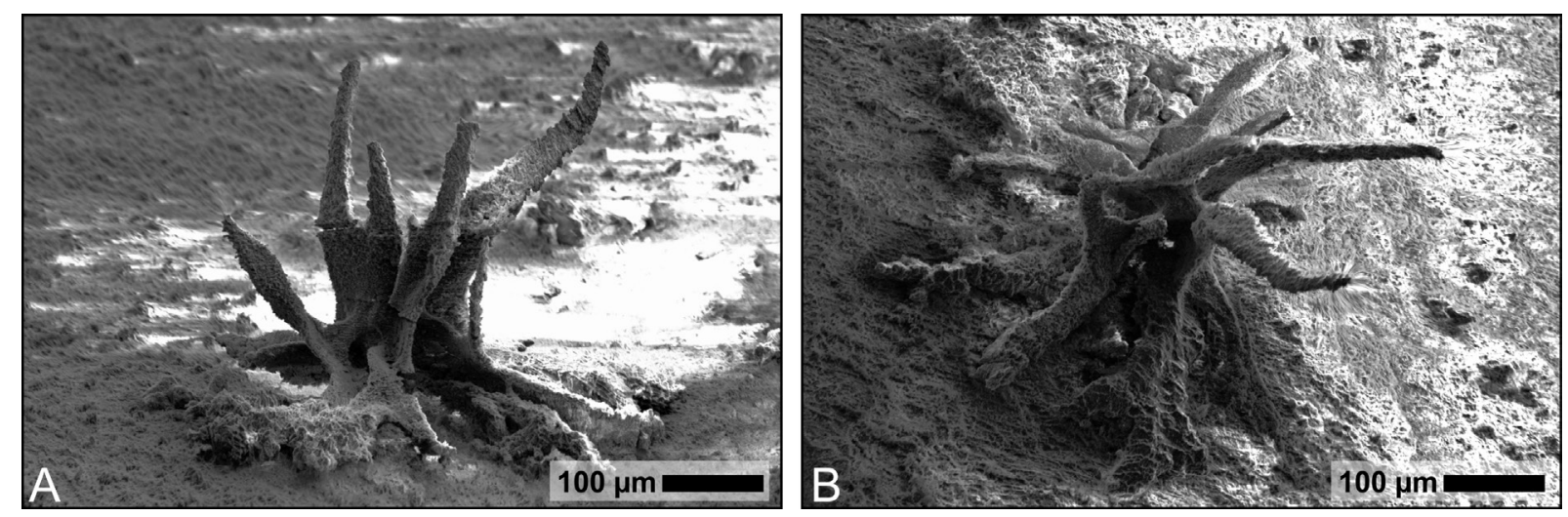

Fig. 23. Pyrodendrina cupra Tapanila, 2008. A-B. SEM of the holotype, cast in epoxy from a shell of the brachiopod Pentamerus palaformis Jin \& Copper, 2000 from the Early Silurian of Anticosti Island, Canada. 
toward their distal part. As with proximal canals, distal canals are thickest nearest the central node and they have greatest dimension in the vertical plane. Branching in the distal canals is less frequent than in the proximal canals. The width of the distal canals averages $41 \mu \mathrm{m}$ at their contact with the central node and they extend distally for an average length of $187 \mu \mathrm{m}$ to give the microboring a penetrative depth of up to $312 \mu \mathrm{m}$. The maximum horizontal span of the distal canals $(\sim 300 \mu \mathrm{m})$ generally does not exceed the diameter of the proximal rosette. [...] Different specimens exhibit different ontogenetic stages in the development of the microborings. The rosetted microboring appears to initiate as a single vertical canal. Unbranched solitary canals are observed at a maximum depth of $\sim 100 \mu \mathrm{m}$. The solitary canal continues to penetrate to a depth of $\sim 200 \mu \mathrm{m}$ and branches once to form a hooked appearance, although no proximal branches are evident at this point of the microboring's development. A third branch in the development of the boring produces a trident shape with a maximum penetration of $\sim 300 \mu \mathrm{m}$. At the trident phase of branching, all distal canals are dominantly vertical, roughly equidistant, and connected at their branching point by a widening of adjacent canals, akin to the webbing between fingers. Proximal canals appear to originate during the trident phase, and the widened branch point of the distal canals appears to serve as the initiation of the central node. An increased number of distal and proximal canals along with a widening of the confluent central node characterize the mature phase [...].

\section{Type material, locality and horizon}

Holotype (Fig. 23A-B) and paratype are cast in epoxy from a shell of the brachiopod Pentamerus palaformis Jin \& Copper, 2000 from locality A1187 (UTM: 12E/1 544400/5454300), southern Anticosti Island, Québec, Canada. Goéland Member, Jupiter Formation, Early Silurian. They are deposited at the Geological Survey of Canada, Ottawa, Ontario, Canada (GSC 10854).

\section{Stratigraphical range}

Late Ordovician to Early Silurian (Tapanila 2008).

\section{Remarks}

Even though Pyrodendrina cupra was found to be very common in the Late Ordovician to Early Silurian of Anticosti Island, with nearly 1 out of 10 brachiopods (5 different species) containing specimens filled with pyrite, iron oxide or micrite, it has not been reported from elsewhere. However, dendrinids preserved as internal moulds in cystoid plates from the Upper Ordovician of Sardinia, as described by Bromley et al. (2007), could represent incompletely preserved $P$. cupra. The phenomenon of incomplete casts was also addressed by Tapanila (2008), who based his original description on a combination of stereomicroscopy and scanning electron microscopy of epoxy resin casts, as well as micro-CT of pyritefilled specimens.

\section{Pyrodendrina arctica isp. nov. urn:1sid:zoobank.org:act:A41E7E41-748C-4DE6-B32F-6383C3852036}

Fig. 24

'Sponge form VI' - (?) Wisshak et al. 2005a: 991, fig. 7F.

'Microsponge-form 6' - (?) Wisshak 2006: 86, fig. 28H.

\section{Diagnosis}

Prostrate galleries with a high degree of anastomosis and a decrease in diameter toward the periphery. From the central node of trace, ramifying, sub-vertical tunnels with tapering terminations extend deeper into the substrate. 


\section{Etymology}

Latinised from the geographic name Arctica, making reference to the known occurrence of this trace being limited to the polar waters off Svalbard and Jan Mayen (as well as one uncertain record from coldtemperate waters off Sweden).

\section{Type material, locality and horizon}

The holotype (Fig. 24A-B) and one paratype (Fig. 24C-D), together with several further specimens, are cast in epoxy resin from a subfossil (possibly Late Pleistocene to probably Holocene) shell of the bivalve Chlamys islandica (O.F. Müller, 1776), sampled in 75 to $85 \mathrm{~m}$ water depth at Sørkappbanken, SW Svalbard Shelf $\left(76^{\circ} 23^{\prime}\right.$ N, $15^{\circ} 57^{\prime}$ E; station 15/161-AGT of the ARK VI/1-4 Expedition of the RV Polarstern in 1989; see Krause et al. 1991 for details). Deposited in the trace fossil collection of the Senckenberg Institute in Frankfurt, Germany (SMF XXX 864, including the holotype, and SMF XXX 865 , including the paratype).

\section{Description}

This species describes relatively large dendrinids with a basal network of anastomosing galleries, running closely parallel to the substrate surface and emerging from an indistinct central cavity (Fig. 24A-E).
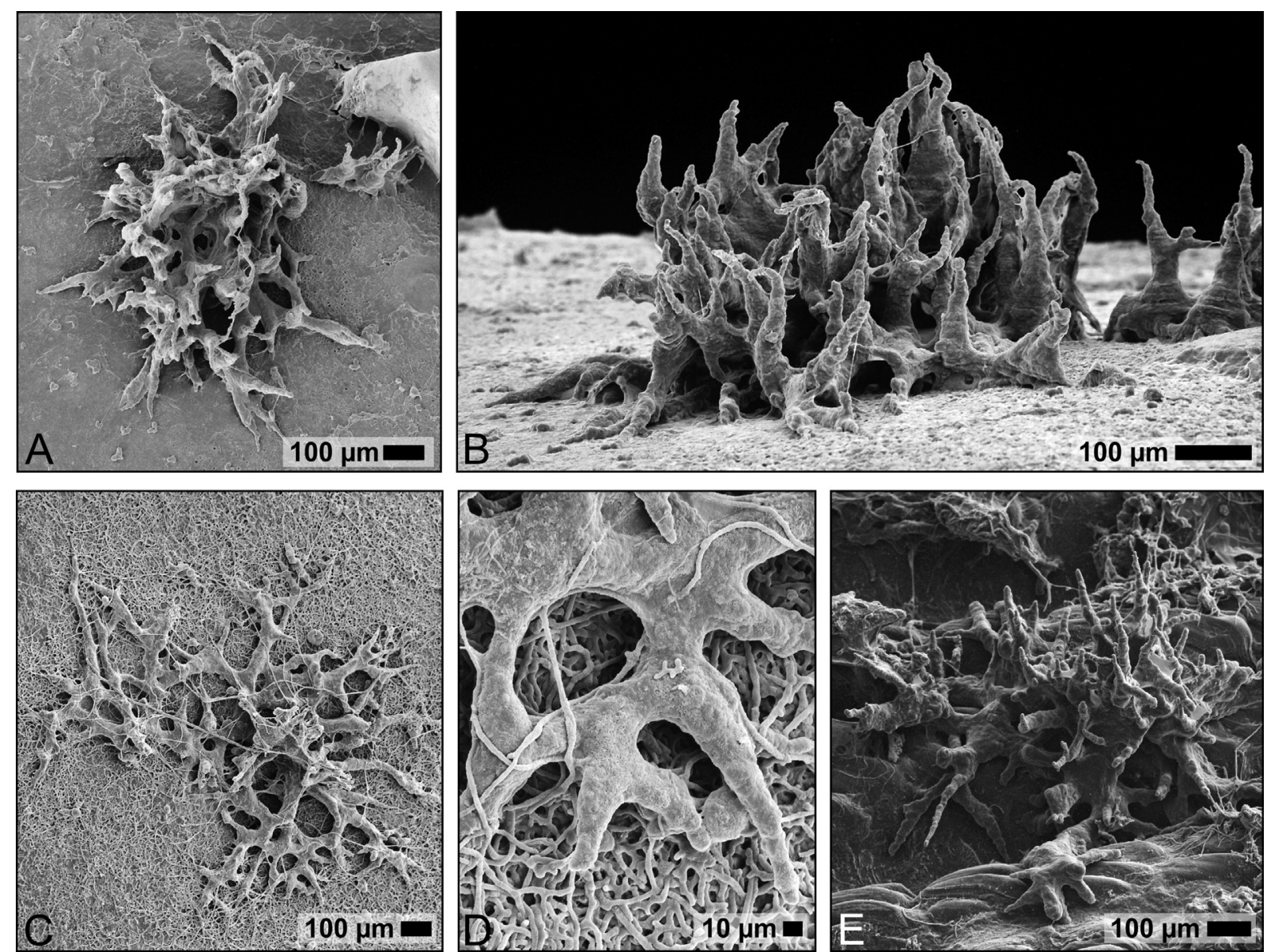

Fig. 24. Pyrodendrina arctica isp. nov. A-B. SEM planar and side views of the holotype found in epoxy cast of a shell of the bivalve Chlamys islandica (O.F. Müller, 1776) sampled off SW Svalbard. C-D. SEM overview and close-up of the paratype recoded in the same shell. E. SEM of a specimen from another (probably Holocene) bivalve shell sampled at a depth of $78 \mathrm{~m}$ in Straumsflaket, near Jan Mayen. 
At least near the centre of the trace, vertically-oriented tunnels reach deeper into the substrate (e.g., Fig. 24A-B), with rapidly ramifying, tapering, and pointed terminations. The overall appearance of the trace in side view resembles a blazing campfire - in accordance with the ichnogenus name (Fig. 24A).

Measured complete specimens range from 1067 to $2936 \mu \mathrm{m}$ in maximum diameter (mean $=1779$ $\pm 564 \mu \mathrm{m} ; \mathrm{n}=180)$, at a width of 824 to $2301 \mu \mathrm{m}($ mean $=1405 \pm 447 \mu \mathrm{m} ; \mathrm{n}=17)$.

\section{Remarks}

Since no deep-time fossil material is available and neither the exact age of the substrate (Pleistocene to Holocene) nor that of the boring is known, the type material is herein regarded as fossil. This is in concord with the view that bioerosion traces in skeletal or lithic hard substrates can be regarded as "ready-made fossils" with a fossilisation barrier most practically defined as the death of the borer (Bromley \& Nielsen 2015). Since no definition of the fossilisation barrier is given in the ICZN, this practice does not violate the Code.

This large Pyrodendrina is distinguished from other ichnospecies in that ichnogenus by the high degree of anastomosis in the basal rosette, and the higher number and density of vertical tunnels. In contrast to $P$. belua isp. nov. and $P$. villosa isp. nov., the surface texture is smooth.

Pyrodendrina belua isp. nov. urn:1sid:zoobank.org:act:D5F00DD3-FFAF-4C73-B044-0F3C8C9248BD

Fig. 25

?Semidendrina pulchra - Wisshak et al. 2008: 43, fig. 9C-E.

\section{Diagnosis}

Prostrate galleries slender, with bi- or trifurcations and rare anastomosis. Additionally, sub-vertical tunnels reach straight into the substrate. All galleries end in widened terminations and are ornamented with short spiny protrusions.

\section{Etymology}

From the Latin 'belua', monster (for the most part in the sea), referring to the former working name "the beast" this trace had earned because of its "fur" and "vertical teeth".

\section{Type material, locality and horizon}

The holotype (Fig. 25A-E) is cast in epoxy of a bivalve shell from the Buckhorn Asphalt, Boggy Formation, Deese group, Desmoinesian, middle Pennsylvanian, sampled at the Buckhorn Asphalt Quarry, Oklahoma, USA. The epoxy cast is stored in the Bayerische Staatssammlung für Paläontologie und Geologie München, Germany (BSPG 2007 XII 12d). For further details about the type locality and its ichnological record, see Wisshak et al. (2008).

\section{Description}

The basal dendritic network of straight galleries displays uni- or bilateral ramification at $45^{\circ}$ to $55^{\circ}$ and rare anastomoses (Fig. 25A, E). All galleries end in slightly widened terminations (Fig. 25A-E). From these basal galleries, additional tunnels of slightly larger diameter, with or without perpendicular side branches, penetrate the substrate sub-vertically and likewise end in widened terminations (Fig. 25B-D). The entire trace has a bulged surface texture and is ornamented with short spiny protrusions (Fig. 25D). 
The holotype measures $594 \mu \mathrm{m}$ in length and $296 \mu \mathrm{m}$ in width, and has a maximum penetration depth of $235 \mu \mathrm{m}$. The horizontal galleries measure $20.9 \pm 6.5 \mu \mathrm{m}$ in thickness $(\mathrm{n}=10)$ and the vertical tunnels are slightly thicker, $24.3 \pm 5.8 \mu \mathrm{m}(\mathrm{n}=10)$. The spiny protrusions measure up to $15 \mu \mathrm{m}$ in length.

\section{Remarks}

Originally tentatively assigned to Nododendrina europaea (as Semidendrina pulchra), this trace is now recognised as a different ichnospecies. It is clearly distinguished from $N$. europaea by the lack of a vertically oriented main node, by the almost complete lack of anastomosis, and by the presence of many vertically oriented galleries.

Distinguished from other ichnospecies of Pyrodendrina by its straight and slender galleries, which always widen near their termination. The central node is least distinct in this species, and the hairy ornament is less pronounced than in P. villosa isp. nov.

Pyrodendrina villosa isp. nov.

urn:1sid:zoobank.org:act:1365F057-8115-4FF7-9F0D-48E5C896CECA

Fig. 26

Morfotipo $\mathrm{B}_{4}-$ (?) Mayoral 1988: 306; pl. I, figs 6-7.
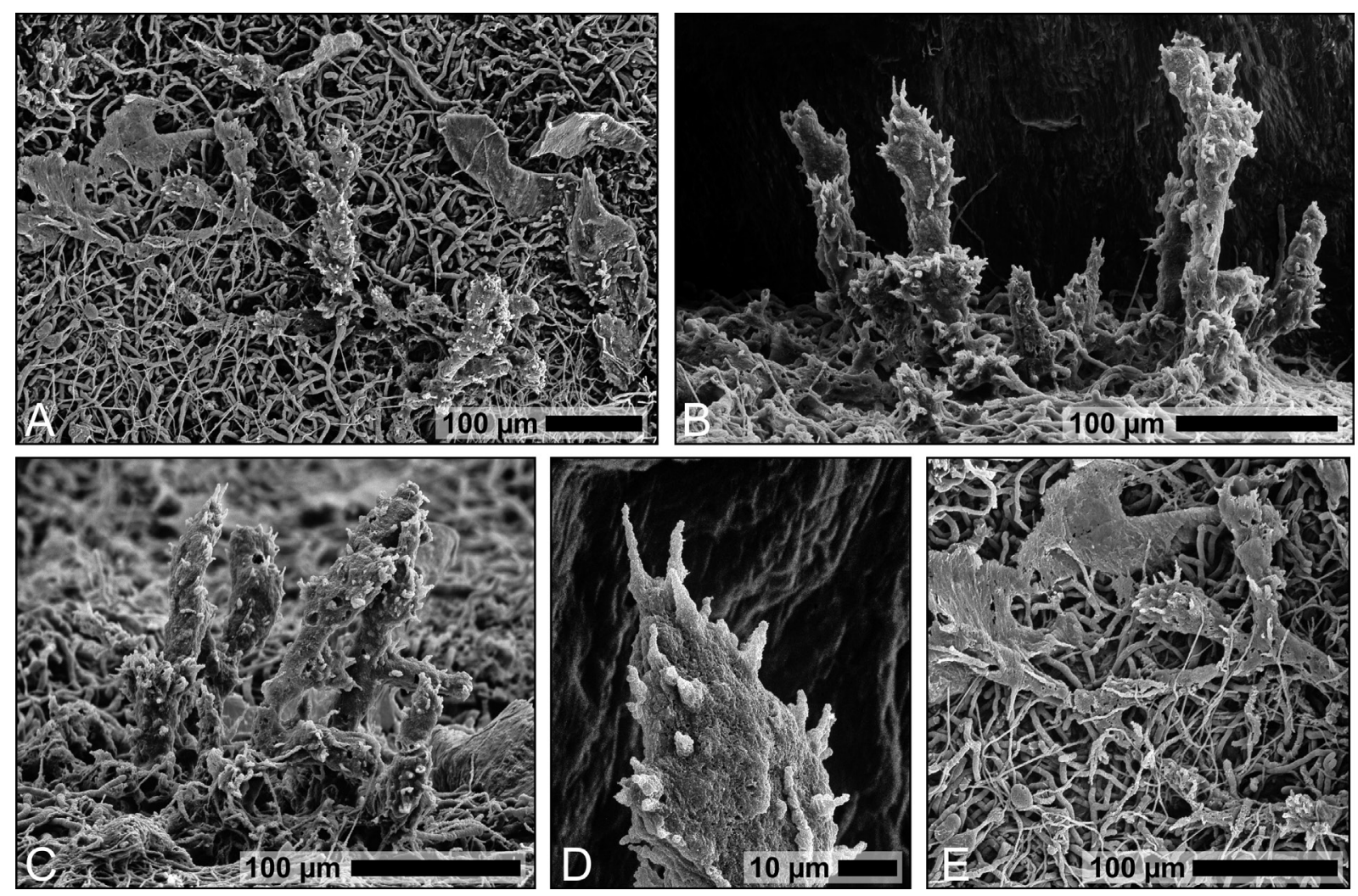

Fig. 25. Pyrodendrina belua isp. nov. A. SEM planar view of holotype, surrounded by a carpet of other microborings in an epoxy cast prepared from a bivalve shell sampled from the Middle Pennsylvanian Buckhorn Asphalt Lagerstätte in Oklahoma, USA. B-C. Lateral views of holotype illustrating vertically oriented galleries, parts of which bearing perpendicular side braches. D. Detail of terminal widening and spiny ornamentation. E. Detail of slender prostrate galleries with terminal swellings and typical branching pattern; an anastomosis is developed at the lower right. 
Sponge form II - Wisshak et al. 2005a: 991, fig. 7B.

Semidendrina Form - Wisshak et al. 2005a: 993, fig. 9.

Foraminiferan trace - Försterra et al. 2005: 957, fig. 9D-H.

non-camerate radiating form - Bromley 2005: 908, fig. 10.

Hirsute camerate form - (?) Bromley 2005: 908, fig. 11.

Semidendrina-form - Wisshak 2006 (partim): 91, fig. 29C-D.

Microsponge-form 2 - Wisshak 2006: 84, fig. 28D.

Foraminiferan Form - Beuck et al. 2010 (partim): 467, fig. 8C-D.

Clionolithes isp. - (?) Pokorný \& Štofik 2016: fig. 11L.

\section{Diagnosis}

Central node of elongate to irregular shape located at shell surface as open channels, with branched and tapered galleries radiating from it, as well as shorter vertical tunnels penetrating deeper into the substrate. Gallery terminations blunt to tapered, ornamented with long, hairy protrusions.

\section{Etymology}

From the Latin 'villosus', villous, a reflection of the irregular, furry ornamentation of this trace.

\section{Type material, locality and horizon}

Holotype (Fig. 26A-D) and a number of additional specimens cast in epoxy from a Lophelia pertusa coral skeleton from the Lindos Bay Formation, Middle Pleistocene, found at isolated hill one km SW of Lardos, Rhodes, Greece. For further details concerning the type locality and its ichnological record, see Titschack et al. (2013) and Wisshak (2008). Deposited in the trace fossil collection of the Senckenberg Institute in Frankfurt, Germany (SMF XXX 866).

\section{Description}

The irregularly-shaped and branched central cavity of this large Pyrodendrina ichnospecies is developed as system of open channels at the substrate surface (Fig. 26A, E-F), while side branches radiating from it may run as tunnels closely parallel to and below the surface. The true extent of the open channels may be uncertain due to collapse of the thin roof of the trace, particularly in taphonomically advanced stages. Anastomoses are rare. The overall outline of the trace may be elongate (Fig. 26G) to more rosetted (Fig. $26 \mathrm{H}-\mathrm{I}$ ), and the number of lateral branches varies strongly. The cross section of the side branches varies from circular to horizontal flattened or vertically condensed. Gallery terminations are either blunt or tapered. Along the entire central node and the radiating branches, vertically oriented projections may reach deeper into the substrate and taper (Fig. 26D, G). A multitude of spiny protrusions extend deeper into the substrate or form a horizontal extension or contact to the substrate surface in the case of prostrate cavities (Fig. 26C, I). Apart from the hairy ornament, the surface texture is irregularly bulged and in some cases weakly cuspate.

Trace diameters measured from epoxy casts of 18 specimens from various localities (see below) yield a maximum length of the trace ranging from 1107 to $3844 \mu \mathrm{m}$ (mean $=2461 \pm 759 \mu \mathrm{m}$; measured without peripheral spiny protrusions), and a maximum width of 1005 to $2389 \mu \mathrm{m}$ (mean $=1601 \pm 478 \mu \mathrm{m}$ ). Radiating galleries have diameters of 35 to $245 \mu \mathrm{m}$ (mean $=99 \pm 37 \mu \mathrm{m} ; \mathrm{n}=160)$. The maximum length of the spiny protrusions ranges from 83 to $392 \mu \mathrm{m}$ (mean $=240 \pm 111 \mu \mathrm{m}$ ).

\section{Remarks}

Additional material was investigated from Miocene bivalves from SE Australia, Pleistocene cold water corals sampled in Messina, Sicily, Recent cold water coral reef sites such as Stjernsund and Sula Reef (Norway), Säcken Reef (Sweden), reefs off Santa Maria di Leuca (Italy), and from a subfossil arctic bivalve shell sampled off SW Svalbard. 
This large ichnospecies of Pyrodendrina is distinguished from other members of the ichnogenus by its development of open channels and by the particularly pronounced spiny surface texture. It has the shortest vertical galleries in relation to the dimension of the horizontal cavity.
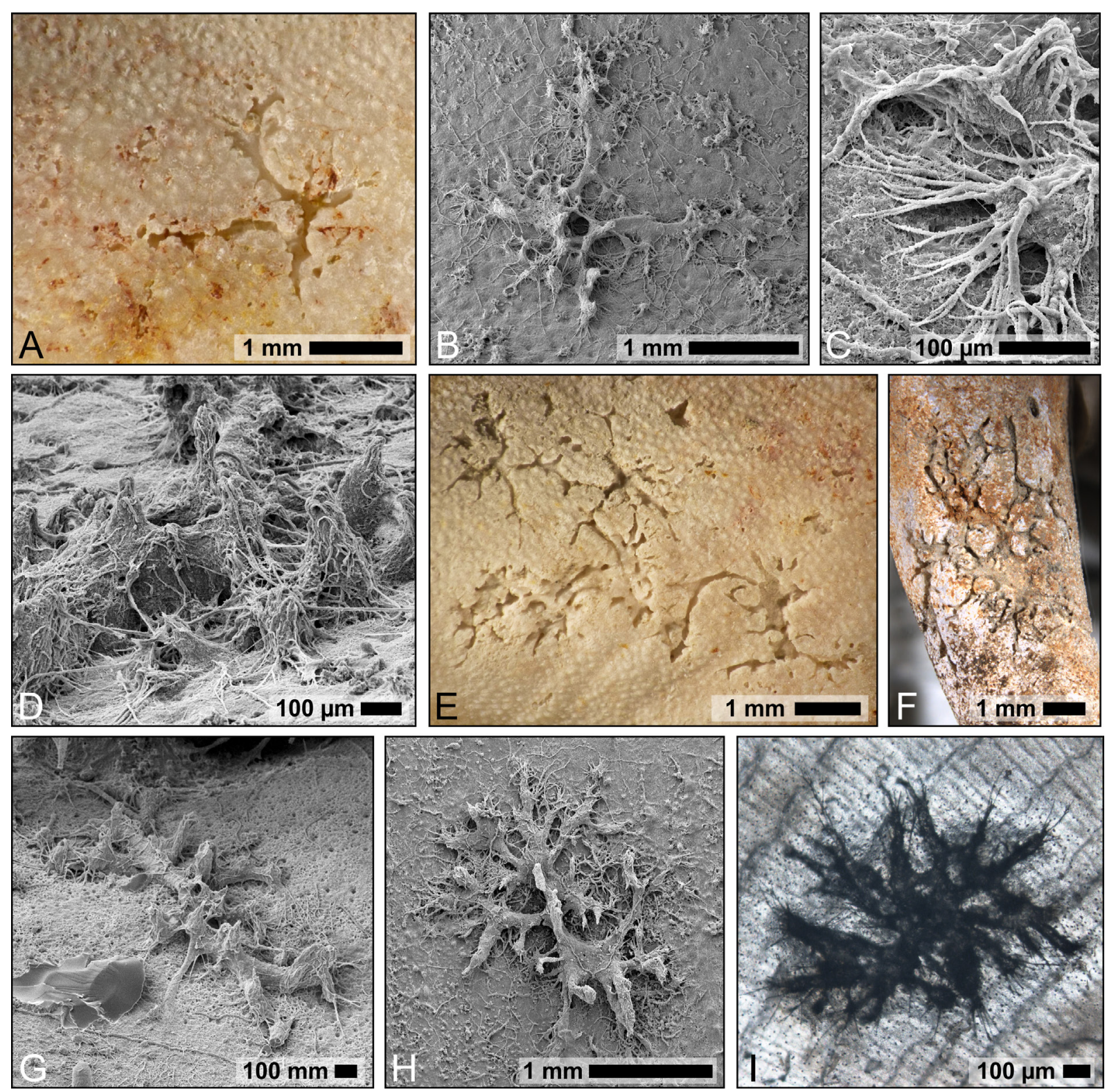

Fig. 26. Pyrodendrina villosa isp. nov. A. Holotype in a Pleistocene skeleton of the coral Lophelia pertusa (Linnaeus, 1758) from Rhodes, Greece, prior to epoxy casting. B. SEM of same holotype in epoxy cast. C. Detail of holotype illustrating hairy ornamentation (collapsed to cast surface). D. Detail of central part of holotype, showing diagnostic vertically oriented protrusions. E. Numerous specimens in the same coral fragment as the holotype. F. Same type of traces in a Recent skeleton of Lophelia pertusa from Stjernsund, Norway. G. SEM of another specimen with an elongate overall morphology, found in a Pleistocene cold water coral from Rhodes, Greece. H. Specimen with a more rosette-shaped outline, found in a skeleton of the coral Keratoisis Wright, 1869 from the Pleistocene of Messina, Sicily. I. Transmission light micrograph of a specimen in a shell of the bivalve Delectopecten vitreus (Gmelin, 1791) from Sula Reef, off Norway. 


\section{Rhopalondendrina igen. nov. urn:1sid:zoobank.org:act:A6A6E53D-9F78-4B9D-BE32-35AF0A52CA55}

\section{Type ichnospecies}

Rhopalondendrina avis igen. et isp. nov.

\section{Diagnosis}

Bioerosion trace in calcareous skeletal substrates with a tubular, straight to arcuate entrance tunnel leading to a prostrate plexus of ramifying or anastomosing galleries, forming up to a semicircle to one side of the point of entry.

\section{Etymology}

Latinised from the ancient Greek ' $\rho$ ó $\pi \alpha \lambda \nu^{\prime}$ ' (rhopalon), club, and ' $\delta \varepsilon ́ v \delta \rho o v$ ' (dendron), tree, referring to the club-shaped widening of terminal galleries in the type ichnospecies, and acknowledging the corresponding informal naming of the Rhopalondendrina-Form by Ingrid Glaub (1994).

\section{Remarks}

Distinguished from Nododendrina by the lack of a vertical node below the point of entry and from Abeliella by the differing principle substrate type. Distinguished from all other dendrinids by the presence of the tubular entrance tunnel and/or the general outline of the plexus.

Rhopalondendrina avis igen. et isp. nov. urn:lsid:zoobank.org:act:A89737C0-E973-442E-A6D0-01994CDF660A

Fig. 27

J-Form F-4 - Glaub 1988: 154, fig. 3D.

Rhopalondendrina-Form - Glaub 1994: 132, pl. 12, figs 1-2.

Rhopalodendrina form - (?) Vogel \& Marincovich 2004: 12, fig. 4.1.

Without name - Thuy et al. 2014: 2, fig. 1i.

\section{Diagnosis}

Entry tunnel straight or arched, leading to a mainly dichotomously and rarely trichotomously ramifying plexus of prostrate tunnels. Increase in tunnel diameter and lateral widening at branching points or terminations towards the periphery of the trace. Converging tunnels fuse to form anastomoses or evade and develop deeper tiers.

\section{Etymology}

Based on the Latin 'avis', bird, acknowledging Prof. Dr. Klaus Vogel (Vogel, German $=$ bird) and his team (including Ingrid Glaub, referred to in the etymology of this new ichnogenus) in Frankfurt, who contributed immensely to the understanding of microbioerosion processes.

\section{Type material, locality and horizon}

The trace was recorded in epoxy resin casts of unidentified belemnite rostra from marls of the Kehlbach and Scheck Members within the Adnet Formation, Sinemurian to Pliensbachian, Early Jurassic, exposed in the Glasenbach Gorge, south of Salzburg in the northern Calcareous Alps, Austria. For further details concerning the type locality and its ichnological record, see Thuy et al. (2014). The holotype 

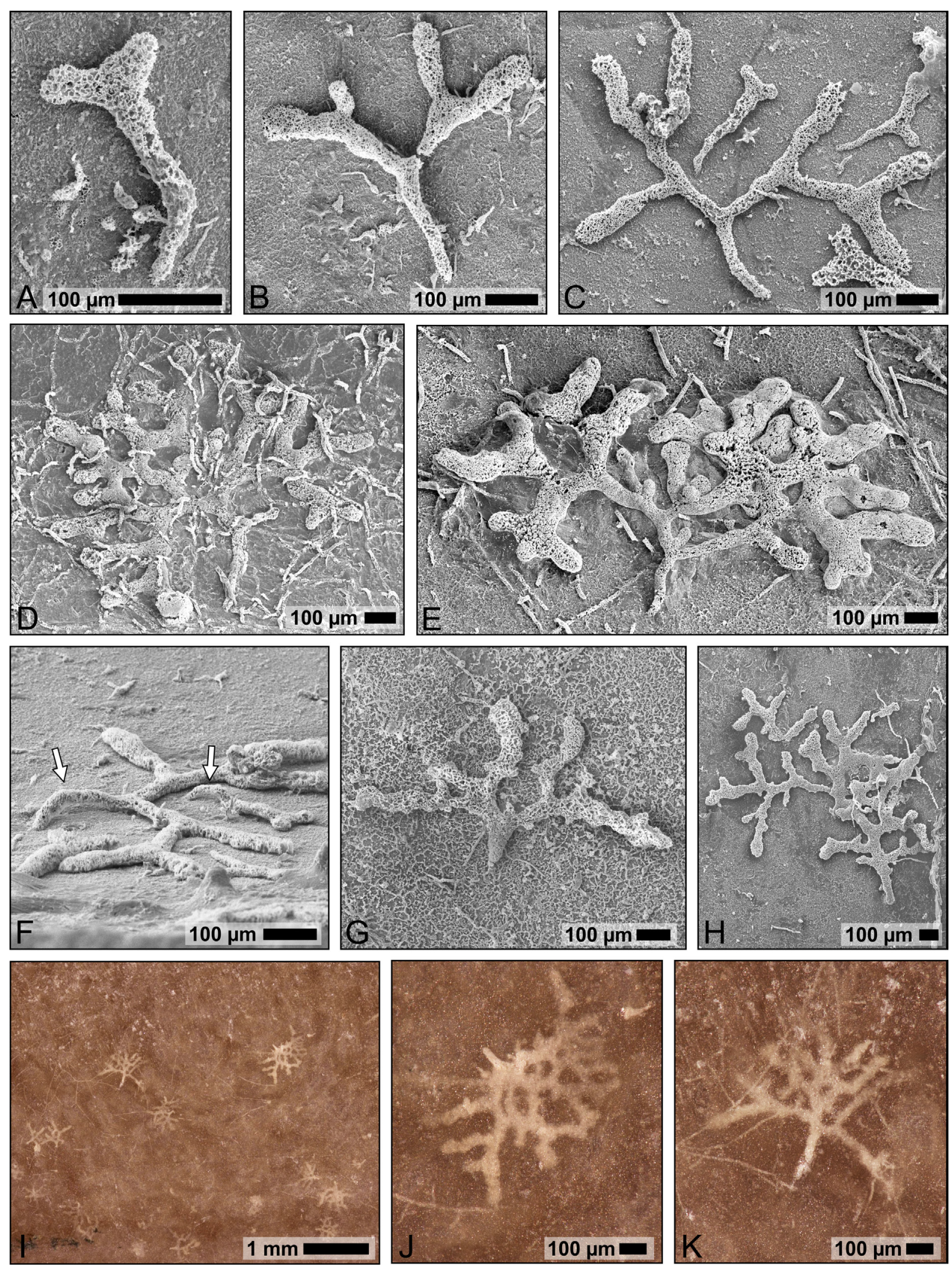
(Fig. 27E) and four paratypes (Fig. 27A-D, F) are preserved in three epoxy resin casts, together with many other traces of the new ichnospecies, and are deposited in the trace fossil collection of the Senckenberg Institute in Frankfurt, Germany (SMF XXX 867, including the holotype, SMF XXX 868, including one paratype and SMF XXX 869, including three paratypes).

\section{Description}

From a single point of entry, a short and nearly straight or slightly arched gallery (Fig. 27F) leads to a first dichotomous ramification (Fig. 27A). The two resulting tunnels repeatedly ramify (or end blindly), typically dichotomously, occasionally trichotomously, with a total number of up to six subsequent branching points (Fig. 27B-F). The nearly bilaterally symmetrical system of galleries runs closely parallel to, or directly below, the substrate surface. In more developed ontogenetic stages with converging galleries, these may fuse and form an anastomosing pattern (Fig. 27D-E), or they may evade and form deeper tiers (Fig. 27E). The diameter of the tunnels increases from the initial gallery towards the periphery of the trace, and terminations are laterally slightly widened. In late ontogenetic stages, the lateral widening of the gallery terminations and ramification points is most pronounced (Fig. 27E).

Among the observed $\sim 50$ specimens from the type locality, 12 traces were complete (including a wide range of ontogenetic stages) and were documented by SEM images in planar view, allowing for accurate morphometrical measurements. These traces ranged from 418 to $1057 \mu \mathrm{m}$ in maximum length $($ mean $=653 \pm 188 \mu \mathrm{m})$ and 425 to $1570 \mu \mathrm{m}$ in maximum width $($ mean $=803 \pm 359 \mu \mathrm{m})$. The initial gallery was found to be 144 to $294 \mu \mathrm{m}$ in length (mean $=217 \pm 44 \mu \mathrm{m}$ ) and 29 to $45 \mu \mathrm{m}$ in diameter $($ mean $=34 \pm 5 \mu \mathrm{m})$. The angle of dichotomous bifurcations varied from $55^{\circ}$ to $136^{\circ}$, with a mean of $90^{\circ} \pm 15^{\circ}(\mathrm{n}=89)$ and the internodes measured 56 to $263 \mu \mathrm{m}$ in distance, with a mean of $123 \pm 36 \mu \mathrm{m}$ $(\mathrm{n}=98)$. The diameter of the tunnels, measured halfway along the internodes, varied from 28 to $99 \mu \mathrm{m}$, with a mean of $52 \pm 14 \mu \mathrm{m}(\mathrm{n}=180)$ and the widened terminations were 30 to $110 \mu \mathrm{m}$ in width, resulting in a mean of $61 \pm 15 \mu \mathrm{m}(\mathrm{n}=112)$. The traces are also very common in Upper Cretaceous belemnite rostra, where they show a comparable branching pattern and similar dimensions (Figs 27G-K).

\section{Remarks}

The traces partly exhibit a limonitic infill that was either impregnated within the epoxy resin or provided a "natural cast" when the belemnite substrate was dissolved in hydrochloric acid. Both in Jurassic as well as Cretaceous belemnites, $R$. avis igen. et isp. nov. often occurs in clusters of up to several tenths of individuals (Fig. 27I).

Early ontogenetic stages closely resemble Abeliella riccioides in morphology, which is, however, by definition restricted to osteic substrates. Similarity is also observed with Fascichnus bellafurcus comb. nov., but this ichnospecies does not exhibit the diagnostic increase in tunnel diameter towards the periphery and it never forms anastomoses where tunnels converge.

Fig. 27 (page 70). Rhopalondendrina avis igen. et isp. nov. A-E. Series of paratypes (A-D) and the holotype (E) showing the development from early ontogenetic stages to advanced stages with several orders of ramification and rosette-shaped plexus with typical increase of tunnel diameter and widening towards the periphery of the trace. SEM of epoxy casts of Lower Jurassic belemnites from the Glasenbach Gorge, Austria. F. Oblique view of C, showing arched nature of initial tunnel (arrow at left). G. SEM of an early ontogenetic stage of a specimen in an Upper Campanian belemnite from Kronsmoor, Germany. H. SEM of a more irregularly branching specimen in a belemnite from the Lower Maastrichtian of Rügen, Germany. I-K. Overview and two close-ups of a typical cluster in a belemnite from the Lower Maastrichtian of Rügen, Germany. 
Rhopalondendrina acanthina igen. et isp. nov. urn:lsid:zoobank.org:act:1C10C48B-2B51-49AB-9D6E-DFA88BDECE92

Fig. 28

Spinate boring form - (?) Zeff \& Perkins 1979: 185, fig. 15.

Sponge from B - (?) Budd \& Perkins 1980: 889, fig. 8D.

Dendroid-Form III - (?) Schmidt 1992: 91, pl. 11, fig. 5. — (?) Glaub \& Schmidt 1994: 106, pl. 3, fig. 2. Dendroid form 2 - Wisshak et al. 2011: 505, fig. 7K.

\section{Diagnosis}

A very short, sub-vertical entrance gallery gives way to a closely prostrate system of irregularly bifurcating galleries, with spiny surface texture and tapering or blunt terminations. Converging tunnels evade and cross, or run parallel to each other.

\section{Etymology}

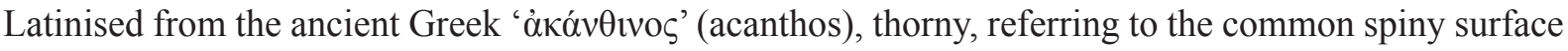
texture of this trace.

\section{Type material, locality and horizon}

The holotype (Fig. 28A) and the paratype (Fig. 28B-C) are found in the same epoxy resin cast from a shell of the bivalve Acanthocardia echinata (Linnaeus, 1758), sampled at the northern flank of an isolated hill one km SW of Lardos village, Rhodes, Greece, in a rhodolith bed determined as Marine Isotope Stage 12, Lindos Bay Formation, Middle Pleistocene. For further details on the type locality and its ichnological record see Titschack et al. (2013) and Wisshak (2008). The epoxy cast is deposited in the trace fossil collection of the Senckenberg Institute in Frankfurt, Germany (SMF XXX 870).

\section{Description}

From a circular point of entry, a very short vertical gallery enters the substrate, from which the main gallery of the closely prostrate tunnel system emerges laterally and increases in thickness until the first point of ramification (Fig. 28A-G). The tunnels commonly bifurcate irregularly at various angles between $45^{\circ}$ and $160^{\circ}$ and with internodes of varying length, forming a trace oriented to one side of the initial entry point. The diameter of the galleries has a moderate variability and distal galleries taper or end bluntly (Fig. 28E-F). The tunnels always feature a dense cover of spiny protrusions, part of which probably connect to the substrate surface (Fig. 28G). Converging tunnels evade and cross, or they run parallel to pre-existing tunnels; true anastomosis has not been observed (Fig. 28E-F).

Among the observed specimens from the Azores experiment (Wisshak et al. 2011; therein addressed as 'Dendroid form 2'), 16 specimens were complete (including a wide range of ontogenetic stages) and were documented by SEM images in planar view, allowing for accurate morphometrical measurements. These traces ranged from 120 to $1020 \mu \mathrm{m}$ in maximum length (mean $=401 \pm 264 \mu \mathrm{m}$ ) and 71 to 1371 $\mu \mathrm{m}$ in maximum width (mean $=430 \pm 370 \mu \mathrm{m}$ ). The initial gallery before reaching the first bifurcation was found to be 10 to $116 \mu \mathrm{m}$ in length (mean $=60 \pm 31 \mu \mathrm{m}$ ) and 10 to $18 \mu \mathrm{m}$ in diameter (mean = $13 \pm 2 \mu \mathrm{m})$. The angle of bifurcations varies from $45^{\circ}$ to $161^{\circ}$, with a mean of $87^{\circ} \pm 19^{\circ}(\mathrm{n}=121)$ and the internodes measure 16 to $266 \mu \mathrm{m}$ in distance, with a mean of $73 \pm 53 \mu \mathrm{m}(\mathrm{n}=120)$. The diameter of the tunnels varies from 17 to $43 \mu \mathrm{m}$, with a mean of $26 \pm 6 \mu \mathrm{m}(\mathrm{n}=229)$. 

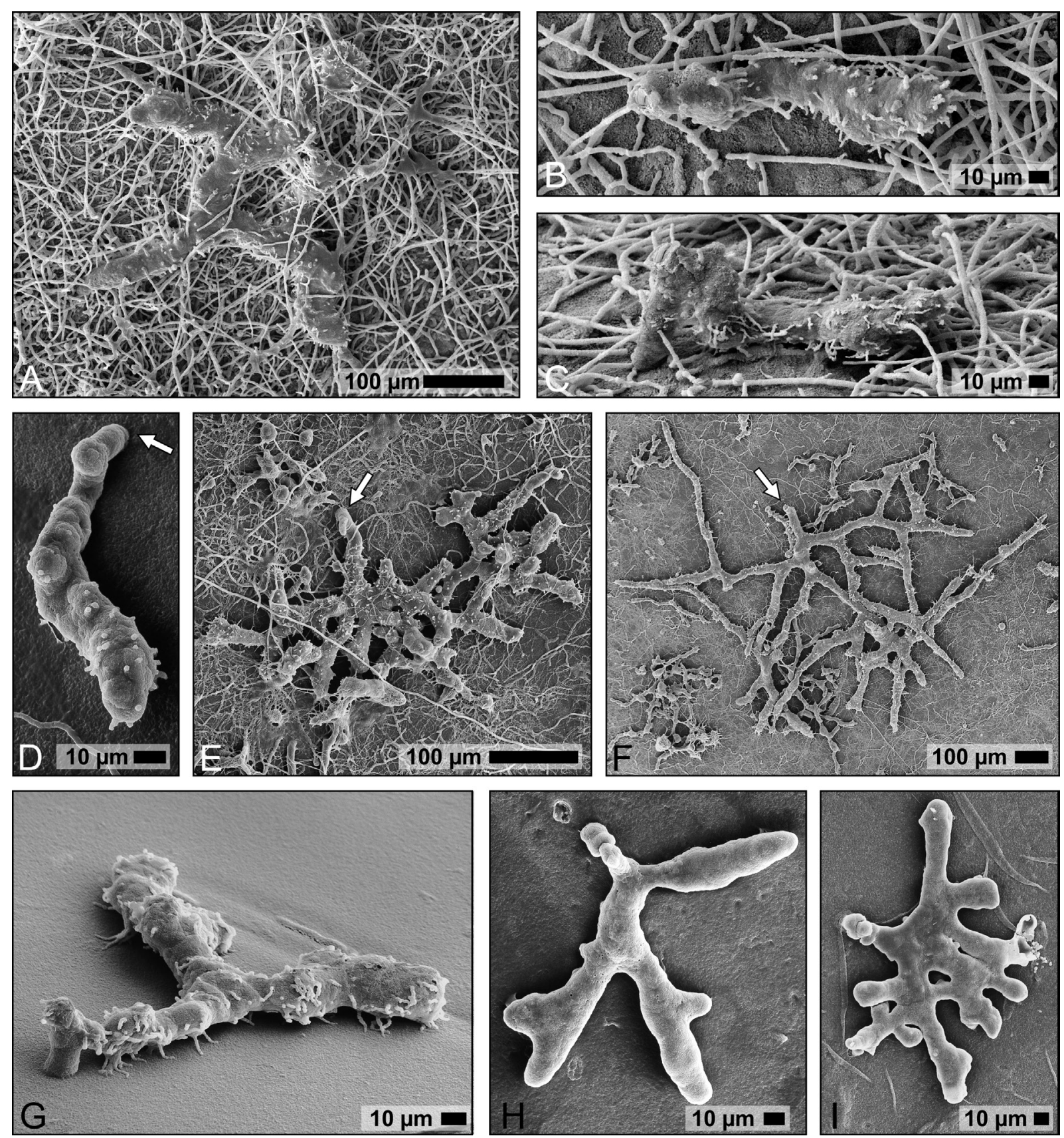

Fig. 28. Rhopalondendrina acanthina igen. et isp. nov. A. SEM of holotype, partly obscured by other microborings, with point of entry at the lower left, in an epoxy cast of a Middle Pleistocene bivalve shell from the Island of Rhodes, Greece. B-C. Planar and oblique views of the paratype, illustrating an early ontogenetic stage with short vertical entrance tunnel; same epoxy cast as the holotype. D-F. SEM of three different ontogenetic stages (arrows indicating initial points of entry), in epoxy casts from experimental bivalve shells deployed at Faial Island in the Azores (same for G-I). G. Oblique view of a specimen with vertical entrance tunnel and short spiny protrusions connecting the trace to the substrate surface. H-I. Two specimens of a related dendrinid from the Azores experiment, awaiting ichnotaxonomical treatment as soon as more material becomes available. 


\section{Remarks}

In contrast to $R$. avis igen. et isp. nov., this ichnospecies never forms true anastomoses, always exhibits a spiny surface texture and has a characteristic, very short and vertical entrance tunnel from which the system of prostrate galleries emerges laterally. It shares the convergent morphological character of the spiny protrusions with the tubular microboring Orthogonum spinosum Radtke, 1991, but is clearly distinguished from it by the formation of a system of irregularly branched and densely spaced galleries rather than straight galleries with alternating and perpendicular short side branches.

A morphologically related and previously undescribed dendrinid microboring was found in the same substrates from the Azores experiment that yielded many Recent $R$. acanthina igen. et isp. nov. This form shows a collar around the short vertical entrance tunnel, the surface texture is very smooth and it does form true anastomoses (Fig. 28H-I). However, an ichnotaxonomical treatment is postponed until more (preferentially fossil) material becomes available.

Rhopalondendrina contra igen. et isp. nov. urn:1sid:zoobank.org:act:93D4CFAE-BABA-4D6C-9DE8-827C4E760446

Fig. 29

Spinate Microborings - (?) Edwards \& Perkins 1974: 1133, fig. 11.

\section{Diagnosis}

Entrance tunnel prostrate or crossing the substrate vertically, leading to a plexus of strongly anastomosing galleries on the same or opposing substrate surface. Plexus covered with short spiny protrusions, some of which connect to the substrate surface.

\section{Etymology}

From the Latin 'contra', across from, referring to the fact that the initial entrance and plexus of the trace may develop on opposing substrate surfaces.

\section{Type material, locality and horizon}

The holotype (Fig. 29A-E), two paratypes (Fig. 29F-H) and several further specimens are cast in epoxy resin of a bivalve shell, sampled in the Balcome Clay, Fyansford Formation, Middle Miocene strata at Fossil Beach, Balcombe Bay, $3 \mathrm{~km} \mathrm{~S}$ of Mornington, Victoria, Australia. The epoxy cast is deposited in the trace fossil collection of the Senckenberg Institute in Frankfurt, Germany (SMF XXX 871).

\section{Description}

From the initial point of entry, an entrance tunnel of roughly constant diameter leads to a plexus of strongly anastomosing galleries that may fuse to form wide lobes (Fig. 29A-H). From the base of the entrance tunnel, further short tunnels may radiate and terminate bluntly (Fig. 29C, E). The entrance tunnel has a smooth surface texture and either runs closely prostrate (Fig. 29C, E-F), or enters and crosses the substrate vertically (Fig. 29G-H). Consequently, in thin substrate shells, the plexus may develop on the same or on the opposite surface of the substrate as the primary entrance. The plexus is oriented closely parallel to the substrate surface and is densely covered with short, spiny protrusions that lead vertically into the substrate or connect the plexus with the substrate surface (Fig. 29G-H).

Morphometric data were derived from a cast with four complete specimens (including the types). The length of the traces varies from 362 to $734 \mu \mathrm{m}$ (mean $=578 \pm 168 \mu \mathrm{m})$, with a similar width of 
363 to $761 \mu \mathrm{m}($ mean $=606 \pm 175 \mu \mathrm{m})$. The initial gallery of the traces measures 156 to $203 \mu \mathrm{m}$ $($ mean $=178 \pm 20 \mu \mathrm{m})$ in length, with a diameter of 17 to $31 \mu \mathrm{m}($ mean $=24 \pm 6 \mu \mathrm{m})$.

\section{Remarks}

This is the only ichnospecies of Rhopalondendrina igen. nov. that was occasionally found traversing the substrate to form the plexus on the opposite shell surface as the initial point of entry. It is furthermore distinguished by showing a very high degree of anastomosis and fusion in the plexus.
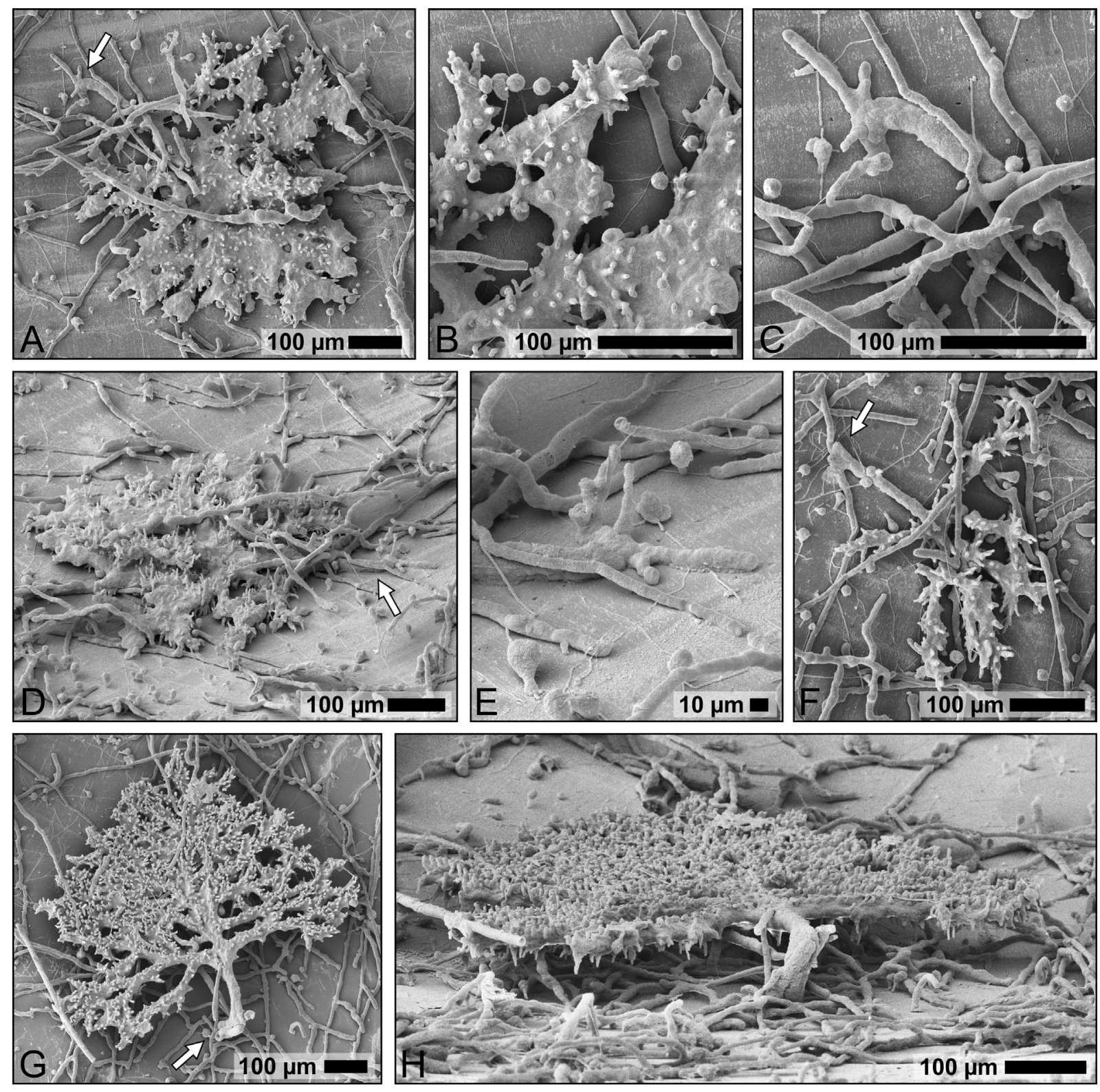

Fig. 29. Rhopalondendrina contra igen. et isp. nov. A-E. Overviews and close-ups of the holotype, illustrating the morphology of the entrance tunnel (arrows in A and D; close-ups in C and E) and the anastomosing plexus, covered with short and spiny protrusions (close-up in B). SEM of epoxy cast of a bivalve shell sampled in Middle Miocene strata at Balcome Bay, Victoria, Australia (same for F-H). F. Juvenile specimen (paratype) with clearly visible entrance tunnel (arrow indicating initial point of entry). G-H. Larger specimen (paratype) with the plexus developed on the opposite surface of the bivalve shell from the initial point of entry (arrow in G). 
Rhopalondendrina tigris igen. et isp. nov.

urn:1sid:zoobank.org:act:F4317101-DB41-4575-A819-43426AF9BC33

Fig. 30

Sponge, Form 1 - Günther 1990: 238, pl. 56, figs 4-7.

Echinoid form - Radtke 1993: 90, pl. 17, fig. 5. — Glaub 2004: 72, fig. 4i.

\section{Diagnosis}

Strongly arcuate entry tunnel, occasionally ornamented with a ridge of vertically oriented tapering protrusions, arches back towards the substrate surface, leading to a flat, palmate cavity with short, round or pointed, finger-like protrusions. Trace connected to the substrate surface by short rhizoidal appendages. Texture irregular to hairy.

\section{Etymology}

From the ancient Greek ' $\tau$ í $p ı \varsigma^{\prime}$ ' (tigris), tiger, referring to the paw-shaped morphology of these dendrinid traces.

\section{Type material, locality and horizon}

The holotype (Fig. 30D) and two paratypes (Fig. 30C, E-F) are found in the same epoxy resin cast from an experimental bivalve shell (Callista) that was bioeroded at a water depth of $15 \mathrm{~m}$ in Pioneer Bay,
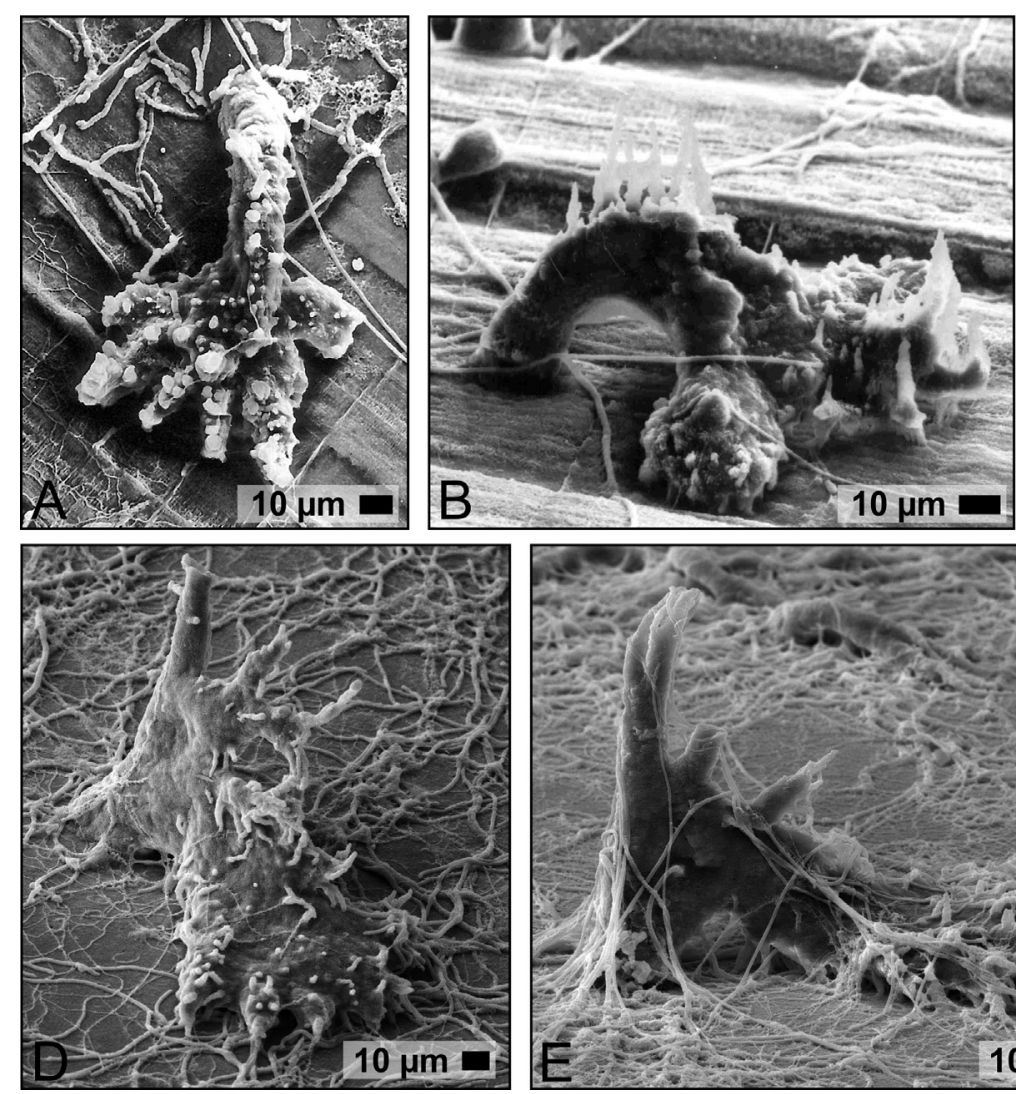
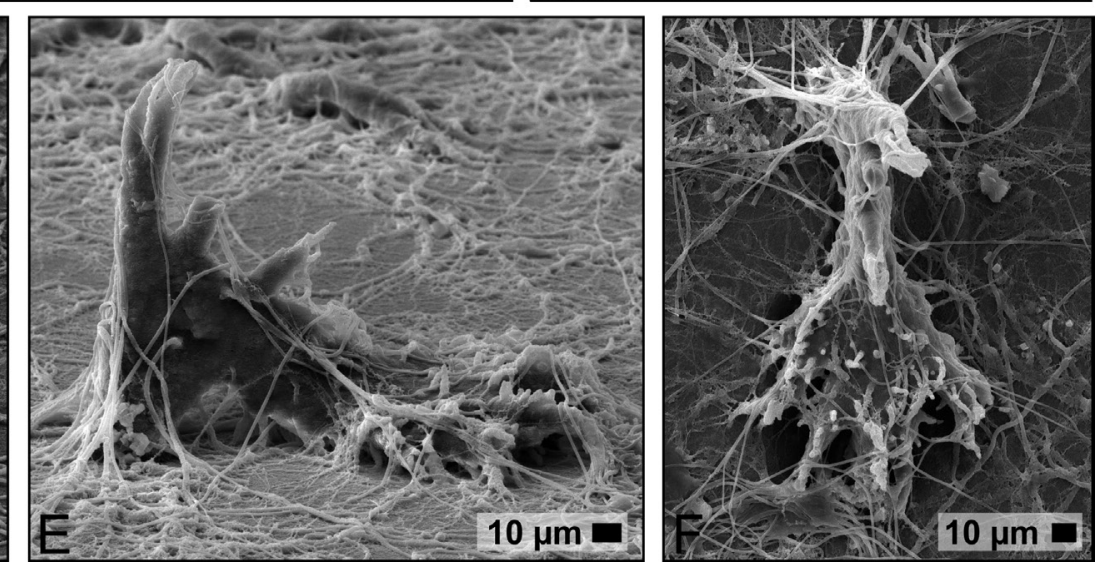

Fig. 30. Rhopalondendrina tigris igen. et isp. nov. A-B. Planar and lateral views of two specimens illustrating the diagnostic arcuate entrance tunnel and paw-shaped main chamber; SEM of epoxy casts from a bivalve shell sampled off Mauritania. C-D. SEM of specimens in an initial (C, paratype) and a mature (D, holotype) ontogenetic stage, cast in epoxy from experimental bivalve substrates that were deployed at the Great Barrier Reef, Australia. E-F. Lateral and planar views of another specimen (paratype) from the type locality. 
Orpheus Island, Great Barrier Reef, Australia. The cast bearing the holotype and paratypes is deposited in the trace fossil collection of the Senckenberg Institute in Frankfurt, Germany (SMF XXX 872).

\section{Description}

The trace originates at a single, circular to oval entrance, from which an arcuate entry tunnel enters the substrate sub-vertically, arches back towards the surface and forms a wide prostrate fan with short, radiating, finger-like, round or pointed protrusions, giving the trace a distinct paw-like appearance (Fig. 30A-F). The surface texture of the entrance tunnel, and particularly of the palmate cavity, is irregular and often bears hairy or cone-shaped protrusions. Along the entrance tunnel, these may form a vertical cockscomb-shaped ridge (e.g., Fig. 30A, D-E). The trace is connected to the substrate surface, at least at the periphery of the trace, by short rhizoidal appendages of only a few micrometres in diameter (Fig. 30C-F).

For morphometrical data, four semi-mature to mature specimens (including the types) were measured. The length of these traces varied from 125 to $179 \mu \mathrm{m}$ (mean $=150 \pm 27 \mu \mathrm{m})$ and the maximum width of the trace measured 53 to $111 \mu \mathrm{m}$ (mean $=85 \pm 30 \mu \mathrm{m}$ ). The diameter of the proximal entrance tunnel measured 21 to $33 \mu \mathrm{m}$ (mean $=27 \pm 5 \mu \mathrm{m}$ ) and the maximum depth of penetration was quantified with a range from 83 to $141 \mu \mathrm{m}($ mean $=109 \pm 26 \mu \mathrm{m})$.

\section{Remarks}

This trace was first reported in samples from Cozumel, Yucatan (Mexico) by Günther (1990) under the informal name 'Sponge, Form 1', and closely reminiscent traces were later reported by Radtke (1993) from mollusc shells sampled at Lee Stocking Island, Bahamas, informally addressed as 'Echinoid form'. This informal name was also adopted by Glaub (2004), who found the trace in samples from depths of 41 to $68 \mathrm{~m}$ on the continental shelf of Mauritania.

All of the three previous records and the new record (from Australia's Great Barrier Reef) are from modern seas, and there is no unequivocal fossil material to choose type material from. However, since this peculiar bioerosion trace is quite distinctive, it is herein nevertheless established as a new ichnospecies, based on the new material from Australia. This is in line with the interpretation of the fossilisation barrier in bioerosion trace fossils, as discussed recently by Bromley \& Nielsen (2015). Since no definition of the fossilisation barrier is given in the ICZN, this practice does not violate the Code.

This ichnospecies is clearly distinguished from the other three ichnospecies of Rhopalondendrina igen. nov. by the strongly arching entry tunnel and the overall paw-shaped appearance of the trace, with only short prostrate appendages.

\section{Antodendrina igen. nov. urn:lsid:zoobank.org:act:F13A16FD-226A-4AFB-852A-3A53A2C3E2FF}

\section{Type ichnospecies}

Antodendrina ligula igen. et isp. nov.

\section{Diagnosis}

Closely prostrate bioerosion trace in calcareous skeletal substrates, with radiating and distally widening lobes emerging from a central cavity, the latter and the lobes being in direct lateral contact to the substrate surface or forming open depressions.

\section{Etymology}

Latinised from the ancient Greek 'óv $\vartheta o \varsigma^{\prime}$ (antos), blossom, and ' $\delta \varepsilon \dot{\varepsilon} \delta \rho \rho v^{\prime}$ ' (dendron), tree, referring to the blossom-like radial appearance of this dendrinid's outline. 


\section{Remarks}

The diagnostic morphological feature of a central depression with radiating club- to spoon-shaped lobes is unique among the Dendrinidae and is the primary ichnotaxobase of this new ichnogenus. Unlike Dendrina, the radiating lobes are in direct contact with the substrate surface.

\section{Antodendrina ligula igen. et isp. nov. urn:lsid:zoobank.org:act:12CB3E8D-D5D7-4C07-B99D-C581C0BED15A}

Fig. 31

\section{Diagnosis}

Initial depression tear-shaped or elongate, with thin connections leading to up to six radiating and distinctly widening lobes with rounded termination, from which thin, ramifying, tapering filaments may emerge.

\section{Etymology}

From the Latin 'ligula', spoon, referring to the shape of the lobes of this dendrinid.

\section{Type material, locality and horizon}

The holotype (Fig. 31A-C) and the paratype (Fig. 31D), together with numerous further specimens in all stages of ontogeny, are cast in epoxy resin from two fragments of Inoceramus sp. bivalve shells from the Upper Campanian (grimmensis/granulosus Zone), sampled in the Saturn Quarry near Kronsmoor, Germany. The casts are deposited in the trace fossil collection of the Senckenberg Institute in Frankfurt, Germany (SMF XXX 873, including the holotype, and SMF XXX 874, including the paratype).

\section{Description}

The characteristic blossom-shaped outline of this dendrinid trace is most conspicuous when filled with white chalk sediment, contrasting the darker colour of the inoceramid bivalve substrate (Fig. 31A, F, $\mathrm{H}$ ), or the inverse pattern in transmission light micrographs of transparent substrates (Fig. 31G). These traces have so far been found, often clustered in high numbers (Fig. 31A, F-G), exclusively in shells of inoceramid bivalves, preferably on their inner surface, where they show various degrees of xenoglyphic patterns caused by the polygonal crystallites of the prismatic shell microstructure (e.g., Fig. 31B, H). From a small initial point of entry, the ontogeny of the trace starts out with a single tear-shaped depression or elongate cavity (Fig. 31E). From this cavity, several radiating and rather rapidly widening (laterally and vertically) lobes emerge, one after another, until a maximum of six lobes are formed. This process partly obscures the original shape of the initial cavity, so that the initial point of entry (Fig. 31B) is not always visible. The lobes are straight or bent and end in blunt, club-shaped terminations, from which ramifying thin galleries may emerge that spread and taper along the delineations of the calcite prisms (Fig. 31B). In some cases, the cavities are shallower and the thin connections of the lobes to the central depression may be almost or actually intermittent. This morphological expression is represented by the paratype (Fig. 31D). In any case, the deepest relief is reached near the terminations of the lobes. Surface texture is uniformly smooth to slightly bulged.

Concerning morphometry, a total of 36 individuals with at least three lobes were measured (including the types). The length of these intermediate or late ontogenetic stages varies from 289 to $675 \mu \mathrm{m}$ $($ mean $=502 \pm 95 \mu \mathrm{m})$ and the central cavity was measured to be 67 to $275 \mu \mathrm{m}$ (mean $=162 \pm 42 \mu \mathrm{m})$ in length. Note that for practical reasons the maximum diameter was measured as the distance between 
opposing terminations of the lobes, even though thin filaments with indistinct terminations may extend a couple of hundred microns further along the substrate surface, leading to an actual extent of the trace of up to around a millimetre. There is a maximum of 6 lobes (mean $=4 \pm 1 ; n=160$ ), with a length of 83 to $308 \mu \mathrm{m}($ mean $=191 \pm 49 \mu \mathrm{m} ; \mathrm{n}=160)$, a minimum width of 7 to $55 \mu \mathrm{m}$ (mean $=21 \pm 8 \mu \mathrm{m}$; $\mathrm{n}=160)$ and a maximum width of 16 to $164 \mu \mathrm{m}($ mean $=73 \pm 26 \mu \mathrm{m} ; \mathrm{n}=160)$.
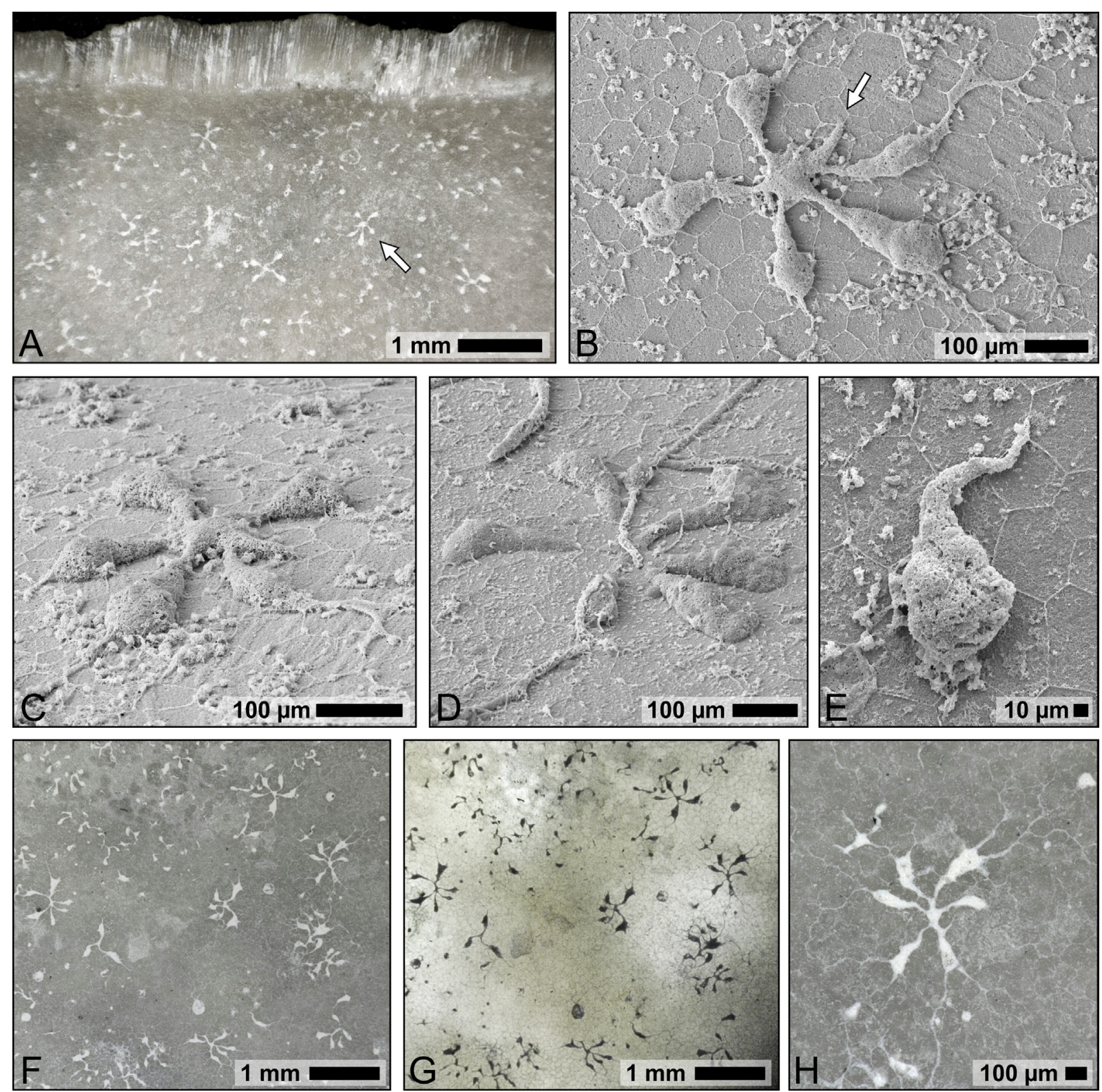

Fig. 31. Antodendrina ligula igen. et isp. nov. A. Typical cluster, including the holotype (arrow), visible on the inner side of an Inoceramus bivalve shell from the upper Campanian of Kronsmoor, Germany, prior to epoxy casting. B-C. SEM planar and oblique views of the holotype in respective epoxy cast, showing initial point of entry (arrow) and slender distal galleries (to the right); surrounded by etching pattern of polygonal shell microstructure as well as granular microborings. D. Paratype with less distinct and shallower central area. E. Initial ontogenetic stage. F-G. Incipient and transmission light micrographs of a shell showing traces in various ontogenetic stages. H. Detail of F showing a mature specimen with six radiating lobes and peripheral filaments following the boundaries of the polygonal crystallites of the prismatic shell layer. 


\section{Discussion}

\section{Compound and composite structures}

In calcareous skeletal material of intermediate to advanced stages of bioerosion, different dendrinids or other trace fossils are often found in direct contact with each other. These contacts are either laterally or vertically overlapping, and they may consist either of closely adjacent cavities or fused borings. Most of these cases are probably random contacts due to space limitations in more densely bioeroded substrates, or they are due to a succession of bioeroders occupying pre-existing cavities. Both of these cases qualify as composite trace fossils. Some of the observed patterns, however, are quite systematic in nature and could rather be the work of the same tracemaker displaying different types of behaviour and hence might better be considered compound trace fossils (see Bertling et al. 2006 for the ichnotaxonomical principles behind compound vs composite structures).

Upper Cretaceous belemnite guards and their rich trace fossil assemblages are a particularly suitable substrate for studying such composite and compound structures. The most obvious examples are the inlet tunnels that lead to the centre of rosettes of Dendrina. While most of these tunnels are short and connect the rosette to the substrate surface (i.e., a diagnostic morphological character of Dendrina), others are more extensive, occasionally exhibiting branching points, and may connect both to peripheral tunnels of conspecific rosettes of Dendrina or to other traces such as Calcideletrix anomala (Fig. 32A-B). The former case indicates a compound structure, whereas the latter represents a composite trace fossil. It is not uncommon that the extensive tunnels in parts undulate and are considerably thickened compared to the usual Dendrina inlet tunnels, and are thus more likely representatives of the ichnospecies Filuroda reptans (Clarke, 1908) (Fig. 32E, G). These instances could be the result of consecutive settlement and widening of pre-existing Dendrina inlet tunnels by another tracemaker, resulting in a composite trace rather than a compound structure. The most conspicuous association was previously noted by Hofmann (1996) and is the combination of several Dendrina lacerata being connected to the periphery of traces of either larger Calcideletrix flexuosa (Fig. 32E-F) or C. anomala (Fig. 32C-D). All three traces occur also in isolation, but the combined occurrence is very common and could either suggest a composite structure produced by the same tracemaker, or alternatively could point towards a parasitic nature of the producer of D. lacerata and its host, the tracemaker of C. flexuosa and C. anomala. These examples demonstrate that without temporal or biological control, the distinction between compound and composite structure is complicated. In any case, none of the observed potential compound structures is unequivocal and indicative enough to merit the establishment of a compound ichnotaxon.

\section{The tracemakers remain enigmatic}

The state of knowledge about the biological identity of the tracemakers that produce dendrinid microborings remains anecdotal and largely speculative. The scarcity of direct evidence stands in contrast to the remarkable diversity of these traces in the fossil record. This is primarily due to the circumstance that only very few dendrinids are known from modern seas - but even in those cases, the tracemaker itself has yet not been clearly identified. Interpretations generally concern endolithic microsponges, foraminiferans, annelids, algae, fungi and cyanobacteria. In the following account, a brief review of hypotheses is given for the various ichnogenera.

The biological origin of Dendrina was questioned by some early workers, such as Morris (1851), who stated in his original description of Dendrina dendrina that it "has been figured with a view of directing the attention of geologists to the subject, as it is doubtful whether it has really arisen from organic action". Quenstedt (1849), in contrast, when establishing Dendrina two years earlier, raised the question of whether they might have formed syn-vivo by a "disease or tapeworm or the like" [translated from German]. Quenstedt (1885) speculated that they might be more closely related to the excavating sponges, an interpretation also given earlier by Fischer (1875). Voigt (1929) followed Quenstedt's 
original interpretation and Mägdefrau (1937), accordingly, considered a parasite living in the space between mantle and rostrum, becoming overgrown in the latter, as the only conceivable explanation for the fact that he could not recognise any connections of Dendrina to the surface of the belemnite guards. However, the unequivocal connectivity of Dendrina to the substrate surface had already been observed by Fischer (1875) and was later confirmed by Schnick (1992) and Hofmann (1996) based
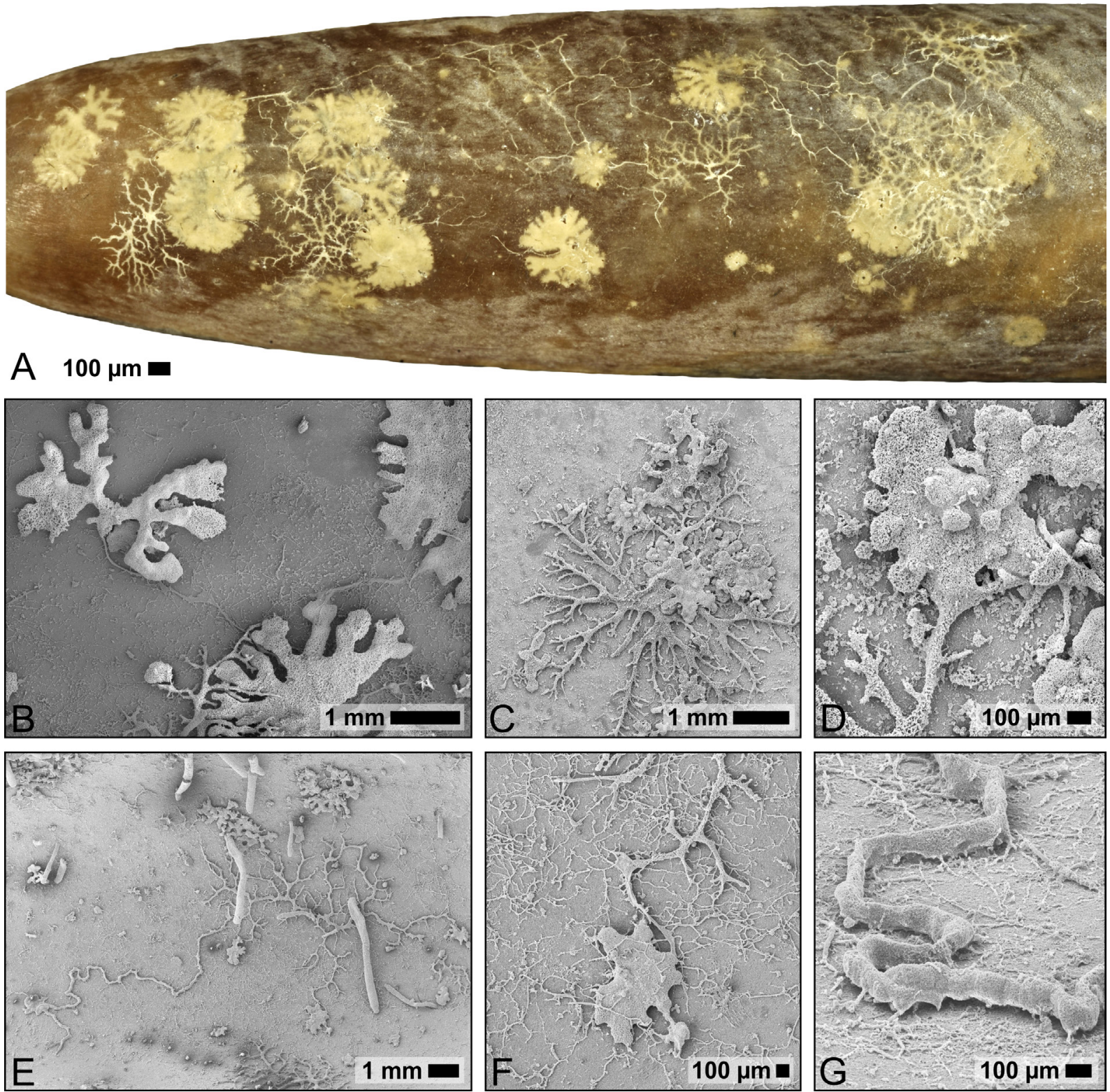

Fig. 32. Composite and compound trace fossils in Upper Cretaceous belemnite rostra from the "Senonian" of Lüneburg, Germany (A), Upper Campanian of Kronsmoor, Germany (B), Lower Campanian of Misburg (C-D), and Lower Maastrichtian of Rügen, Germany (E-G). A. Nice display of Dendrina dendrina (Morris, 1851), D. belemniticola Mägdefrau, 1937, D. lacerata Hofmann, 1996, Calcideletrix anomala (Mägdefrau, 1937) and C. flexuosa Mägdefrau, 1937, partly in lateral contact or overlapping and partly interconnected by tubular tunnels. B. Several $D$. dendrina, interconnected by tubular tunnels. C-D. Overview and close-up of a C. anomala connected to several paratypes of D. lacerata. E-G. Large C. flexuosa connected to several D. lacerata at its periphery (close-up in F), as well as to a widened tubular tunnel reminiscent of Filuroda reptans (Clarke, 1908) (close-up in G). 
on epoxy-resin casts. Due to a preferred orientation related to the taphonomical situation of belemnite rostra halfway buried in the sediment, Marcinowski (1972) and, in more detail, Radwański (1972) objected to the parasitic nature and demonstrated that Dendrina more likely is a post-mortem trace. New observations made in the course of this revision clearly confirm the post-mortem nature of Dendrina and other dendrinids in Cretaceous belemnites by documenting various instances where these traces have formed inside the alveolus or on fracture planes of fragmented belemnites that must have formed postmortem. Reviewing previous hypotheses, Radwański (1972) tentatively supported the idea expressed by Kennedy (1970) of an algal origin, but ultimately considered the tracemaker as enigmatic. A phototrophic tracemaker appears very unlikely, particularly when considering the high abundance of this trace in the Upper Cretaceous central chalk basin of N Germany and Denmark, which is largely considered to be a deeper shelf setting (e.g., Ekdale \& Bromley 1984), even though some topographic heterogeneity was given by a ridge and valley system (Esmerode et al. 2007). Accordingly, the microboring assemblages encountered in Campanian belemnites from this area are devoid of traces produced by phototrophic (eu)endoliths (own observation) and in the Maastrichtian algal microborings are restricted to shallowwater facies that had formed near the end of the Upper Cretaceous regression (Hofmann 1996). Among potential non-phototrophic tracemakers, speculations put forward over the years include excavating sponges (Quenstedt 1885), annelid worms (Zittel 1879), protists (Dacqué 1921) and fungi (Whittlesea 2005). Notwithstanding, more than one and a half century after Dendrina was named, its definitive biological affinity remains an open question.

Clarke's (1908) original interpretation of Clionolithes found its manifestation in the ichnogenus name, meaning "Cliona stone", referring to the hadromerid sponge genus Cliona, the most abundant excavating sponges in modern seas. In the literature, there appears to be a wide consensus in following this original interpretation (e.g., Clarke 1921; Fenton \& Fenton 1932; Solle 1938; Bromley 2004; Tapanila 2006; Wilson et al. 2010; Furlong \& McRoberts 2014), even though there is neither direct evidence, such as reports of specific sponge spicules inside the traces, nor has a modern counterpart of Clionolithes been identified. Nevertheless, some workers even considered Clionolithes as a biotaxon within the phylum Porifera (Branson 1937; Hyde 1953; Easton 1962; Talent 1963). This interpretation as sponge borings was fostered by Plewes (1996), who discovered a distinct cuspate micro-sculpture, called a "pseudo-chip sculpture", on well-preserved specimens of C. alcicornis. In extant excavating sponges, a corresponding, albeit larger cuspate microsculpture is formed by individual etching cells when liberating so-called sponge chips. This texture is a diagnostic feature of sponge borings comprised within the ichnogenus Entobia. A microsculpture reminiscent in dimension to C. alcicornis was reported for the micro-entobian E. mikra Wisshak, 2008, and a relationship to unequivocal sponge borings is furthermore supported by the general morphological overlap to the far larger E. megastoma (Fischer, 1868) and E. dendritica Pleydell \& Jones, 1988.

Owing to the morphological continuum between Clionolithes and Calcideletrix, the producer of the larger ichnospecies of Calcideletrix might well be suspected among the bioeroding sponges. In fact, analogous to the case of Clionolithes, Plewes (1996: pl. 33, fig. 6) observed a cuspate pseudo-chip sculpture in one of her epoxy resin casts of $C$. flexuosa, providing further support for sponges as the tracemakers. Kennedy (1970), in contrast, held boring algae responsible for producing Calcideletrix, an interpretation that is doubted herein for the same reasons as for Dendrina, since both ichnospecies co-occur on belemnite substrates that are thought to have been deposited at aphotic depths (see above). Another analogy to Dendrina is the consideration of Calcideletrix primarily as a feature of post-mortem bioerosion. The smallest representative of this ichnogenus, C. fastigata, always has a smooth surface texture and is in the size range of microendolithic fungi. The pyrite framboids discovered in the type material (see above) could represent pyritised fossil fungal spores. A fungal producer appears likely also for $C$. breviramosa, which bears some morphological affinity to fungal microborings in the ichnogenus Orthogonum Radtke, 1991. 
The tracemaker of Dictyoporus is unknown and subject to speculation only. Elias (1957) considered D. nodosus (addressed as junior synonym Cliona fenestralis) a bioeroding sponge, based on its morphological similarity to small species of Cliona reported by Hancock (1849). Palmer \& Palmer (1977) also suggested a boring sponge as the most probable tracemaker of D. nodosus (addressed as junior synonym Cicatricula retiformis). This interpretation was supported by Lindström (1979), who made a case for the oldest sponge borings found in trilobite fragments from the Lower Ordovician of Sweden. Elias (1980), in contrast, elaborated in detail on the possibility of D. nodosus (addressed as junior synonym Dictyoporus garsonensis) being produced by a partly endolithic and partly epilithic alga. However, a phototrophic producer is herein questioned, at least for Dictyoporus nodosus, again on the grounds of its co-occurrence with Dendrina and Calcideletrix on belemnite substrates that are thought to have been deposited at aphotic depths (see above). A shallow-water environment is evident, in contrast, for the type material of Dictyoporus balani, leading Tavernier et al. (1992) and Tavernier \& Golubic (1993) to propose a phototrophic eukaryotic endolith, possibly a chlorophyte, to be responsible for this ichnospecies (addressed as junior synonym Dendrorete balani). Last but not least, another hypothesis that seems worth putting forward is grounded on the present author's observation of a remarkably close morphological resemblance between the anastomosing network pattern seen in Dictyoporus and the stolon networks developed by certain hydroids, in particular among the extant genera Podocoryne and Hydractinia. Even though Goette (1916) has previously reported the stolon network of these hydroids to not only develop on the surface of their host substrates, but also to grow into or below the outer shell layer of molluscs (periostracum), true bioerosive hydroid networks in the calcareous shell layers have to date not been reported. Further investigations are necessary to better characterise bioerosion vs embedment structures in organic vs calcareous shell layers of substrates colonised by recent hydroids before this interpretation can be promoted for fossil anastomosing networks such as Dictyoporus.

The strictly dichotomous branching pattern of Abeliella is regarded as a common feature of fungi, and both ichnospecies were thus considered by Mägdefrau (1937) as microborings of fungal parasites. This interpretation follows an earlier suggestion by Kölliker (1860), whereas Rose (1855) only referred to the general nature of these borings as being parasitic. However, a dichotomous branching pattern is not limited to organotrophic fungi and is also common among the phototrophic euendolithic chlorophytes and cyanophytes (see discussion in Radtke et al. 2010). Considering the minute dimensions of the Abeliella galleries, a fungal origin nevertheless appears the most likely interpretation to date.

Among the various Nododendrina ichnospecies, $N$. europaea has received closest attention, due to its wide distribution in the fossil record and in modern seas. When describing this ichnospecies based on extant material from the Bay of Biscay, Fischer (1875) attempted to verify a sponge affinity, but after failing to detect spicules he reasoned that the producer was most likely a rhizopod rather than a clionaid sponge. Nododendrina europaea is the only dendrinid that has been found with the body fossil remains of its tracemaker, an agglutinated chimney surrounding its orificium, and was consequently described as the foraminiferan body fossil Globodendrina monile by Plewes et al. (1993). In modern traces, the agglutinated chimney has never been observed and Bromley et al. (2007; for junior synonym Semidendrina pulchra) concluded that the tracemaking foraminiferan either has entirely reduced this feature since the Jurassic, or this circumstance reflects taxonomic diversity. Bioerosion by foraminiferans is a common and diverse phenomenon ranging from surficial attachment etchings, with or without predatory canals, to entirely endolithic crypts and dendrinid traces such as Nododendrina (Plewes et al. 1993; Vénec Peyré 1996; Bromley et al. 2007; Walker et al. 2017). Endolithic forms may have a test embedded and growing in its bioeroded cavity, or may be entirely naked, such as the proposed tracemaker of at least the recent $N$. europaea. Here, the naked foraminiferan could produce the main node of the trace and expand its pseudopodia by means of the anastomosing plexus that connects to the substrate surface in order to allow participation in the feeding current (Bromley et al. 2007). However, direct detection of foraminiferan tissue in this trace is still pending. Considering the morphological similarities between 
the various ichnospecies of Nododendrina, a common general type of tracemaker is likely. Alternative interpretations have been suggested for N. microdendritica by Vogel et al. (1987; as junior synonym Hyellomorpha microdendritica), who assumed an endolithic cyanobacterium with affinity to Hyella as tracemaker, and Schnick (1992), who argued in detail for an endolithic chlorophyte alga as producer. Elias (1957) placed Nododendrina paleodendrica (as Cliona paleodendrica) as a biotaxon within a genus of bioeroding sponges, based on morphological similarities to small species of Cliona reported on earlier by Hancock (1849).

The tracemaker of Pyrodendrina is unknown. Tapanila (2008) excluded a boring foraminiferan for the type ichnospecies $P$. cupra and stated that the tracemaker might be auto- or heterotrophic, due to its occurrence in the photic zone. For the three new ichnospecies of Pyrodendrina, the tracemaker remains unknown as well, but is suspected to be found among boring micro-sponges or endolithic foraminiferans. Due to their occurrence in low-light conditions (except for $P$. belua isp. nov.), a phototrophic tracemaker can be excluded.

The same, admittedly vague suspicion (boring micro-sponges or endolithic foraminiferans) applies to all four ichnospecies of the new ichnogenus Rhopalondendrina, which are too large to be produced by fungi or microphytes, and most of which were found in aphotic (palaeo-)environments.

Likewise, the tracemaker of Antodendrina remains unknown, but is probably expected to be among organotrophic biota, based on its preservation in bivalve shells from the presumably aphotic palaeoenvironment of the Upper Cretaceous chalk basin.

In conclusion, the number of interpretations appears almost as diverse as the number of dendrinid ichnogenera, with the most convincing evidence suggesting that foraminiferans are the producers of Nododendrina and excavating micro-sponges produce Clionolithes and some Calcideletrix. By morphological analogy, these two principal types of tracemakers might represent the most likely candidates for most dendrinids, potentially complemented by endolithic fungi and microphytes as producers of the smaller among the dendrinids, and hydroids as the potential tracemakers of Dictyoporus.

\section{Substrate specificity of dendrinid microborings}

The fossil record yields a wide variety of different substrate types that dendrinid microborings are found in (Table 5). These comprise ten different types of calcareous skeletal substrates, one type of nonskeletal calcareous substrate (lithic hardground) and three types of osteic substrates. Among all of these, bivalves are the most common substrate type, followed by brachiopods, belemnites and corals. Records from other substrate types remain rare, but this is at least partially related to a sampling bias, since these substrates are much less studied with respect to bioerosion trace fossils. The relevance of this factor can be exemplified by the dendrinid ichnogenotype and its type ichnospecies Dendrina dendrina, which prior to the present study was limited to belemnites and bivalves as known substrates and is now recognised also from ammonoid aptyches, brachiopods, cirripeds, serpulids and corals. Any interpretations towards true substrate specificity are thus based on negative evidence only and should only be attempted after an extensive search for traces in alternative substrate types. Reasoning the other way around, it can be concluded that at least Dendrina dendrina, D. lacerata, Clionolithes radicans, Calcideletrix flexuosa, C. anomala, Dictyoporus nodosus and Nododendrina europaea (found on at least four different types of substrate) are not specific to a certain sort of skeletal substrate. This circumstance in turn makes a symbiotic relationship between the tracemakers and their hosts unlikely, in addition to the fact that many dendrinids (e.g., all of the many records in belemnites) were formed post-mortem. 
Table 5. Revised suite of ichnotaxa and the substrate types they were documented from. $\mathrm{T}=$ substrate of holotype; $\mathrm{P}=$ published substrate type; $\mathrm{N}=$ new substrate type; ? = uncertain record; $*$ = type ichnospecies; $* *=$ certain records only.

\begin{tabular}{|c|c|c|c|c|c|c|c|c|c|c|c|c|c|c|}
\hline Ichnotaxon & 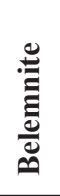 & 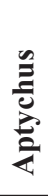 & 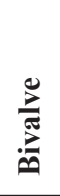 & Ũ & 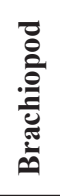 & : & 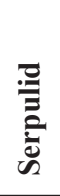 & 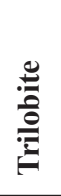 & $\overline{0}$ & 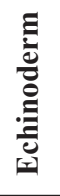 & 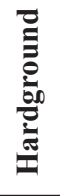 & 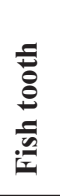 & 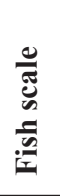 & 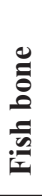 \\
\hline \multicolumn{15}{|l|}{ Dendrina Quenstedt, 1849} \\
\hline D. dendrina (Morris, 1851) comb. nov.* & $\mathrm{T}$ & $\mathrm{N}$ & $\mathrm{P}$ & & $\mathrm{N}$ & $\mathrm{N}$ & $\mathrm{N}$ & & $\mathrm{N}$ & & & & & \\
\hline D. belemniticola Mägdefrau, 1937 & $\mathrm{~T}$ & & $\mathrm{~N}$ & & & & & & & & & & & \\
\hline D. lacerata Hofmann, 1996 & $\mathrm{~T}$ & & & & $\mathrm{~N}$ & & $\mathrm{~N}$ & $\mathrm{P} ?$ & $\mathrm{P} ?$ & $\mathrm{~N}$ & & & & \\
\hline \multicolumn{15}{|l|}{ Clionolithes Clarke, 1908} \\
\hline C. radicans Clarke, $1908^{*}$ & & & $\mathrm{P}$ & $\mathrm{P}$ & $\mathrm{T}$ & & & & $\mathrm{P}$ & & & & & \\
\hline C. palmatus Clarke, 1908 & & & $\mathrm{~T}$ & $\mathrm{P}$ & $\mathrm{P}$ & & & & & & & & & \\
\hline C. pannosus (Solle, 1938) comb. nov. & $\mathrm{P} ?$ & & $\mathrm{~T}$ & & $\mathrm{P}$ & & & & & & & & & \\
\hline C. cervicornis (Vogel et al., 1987) & & & & & $\mathrm{T}$ & & & & $\mathrm{P}$ & & & & & \\
\hline C. alcicornis (Vogel et al., 1987) comb. nov. & $\mathrm{P}$ & & & & $\mathrm{T}$ & & & & & & & & & \\
\hline C. convexus (Hofmann, 1996) comb. nov. & & & $\mathrm{T}$ & & & & & & & & & & & \\
\hline \multicolumn{15}{|l|}{ Calcideletrix Mägdefrau, 1937} \\
\hline C. flexuosa Mägdefrau, 1937* & $\mathrm{T}$ & $\mathrm{N}$ & $\mathrm{P}$ & & $\mathrm{P}$ & $\mathrm{N}$ & & & $\mathrm{N}$ & $\mathrm{N}$ & & & & \\
\hline C. breviramosa Mägdefrau, 1937 & $\mathrm{~T}$ & & & & & & & & & $\mathrm{~N}$ & & & & \\
\hline C. anomala (Mägdefrau, 1937) comb. nov. & $\mathrm{T}$ & $\mathrm{N}$ & $\mathrm{P}$ & & $\mathrm{N}$ & $\mathrm{N}$ & $\mathrm{N}$ & & & & & & & \\
\hline C. fastigata (Radtke, 1991) comb. nov. & & & $\mathrm{T}$ & $\mathrm{P}$ & & & & & & & & & & \\
\hline \multicolumn{15}{|l|}{ Dictyoporus Mägdefrau, 1937} \\
\hline D. nodosus Mägdefrau, 1937* & $\mathrm{T}$ & & $\mathrm{P}$ & $\mathrm{P}$ & $\mathrm{P}$ & & $\mathrm{N}$ & $\mathrm{P}$ & $\mathrm{P}$ & & $\mathrm{P}$ & & & \\
\hline D. balani (Tavernier et al., 1992) comb. nov. & & & $\mathrm{P}$ & & & $\mathrm{T}$ & & & & & & & & \\
\hline \multicolumn{15}{|l|}{ Abeliella Mägdefrau, 1937} \\
\hline A. riccioides Mägdefrau, 1937* & & & & & & & & & & & & $P$ & $\mathrm{~T}$ & $\mathrm{P}$ \\
\hline A. procera Mägdefrau, 1937 & & & & & & & & & & & & $\mathrm{~N}$ & $\mathrm{~T}$ & \\
\hline \multicolumn{15}{|l|}{ Nododendrina Vogel et al., 1987} \\
\hline N. europaea (Fischer, 1875) comb. nov. & $\mathrm{P}$ & & $\mathrm{T}$ & & $\mathrm{P}$ & $\mathrm{P}$ & & & $\mathrm{P}$ & & & & & \\
\hline N. incomposita (Mägdefrau, 1937) comb. nov. & $\mathrm{P}$ & & $\mathrm{N}$ & & $\mathrm{T}$ & & & $\mathrm{P} ?$ & & & & & & \\
\hline N. paleodendrica (Elias, 1957) comb. nov. & & & & & $\mathrm{T}$ & & & & & & & & & \\
\hline N. nodosa Vogel et al., 1987* & & & & & $\mathrm{T}$ & & & & & & & & & \\
\hline \multicolumn{15}{|l|}{ Pyrodendrina Tapanila, 2008} \\
\hline P. cupra Tapanila, 2008* & & & & & $\mathrm{T}$ & & & & & $\mathrm{P} ?$ & & & & \\
\hline P. arctica isp. nov. & & & $\mathrm{T}$ & & & & & & & & & & & \\
\hline P. belua isp. nov. & & & $\mathrm{T}$ & & & & & & & & & & & \\
\hline P. villosa isp. nov. & & & $\mathrm{N}$ & & & & & & $\mathrm{T}$ & & & & & \\
\hline \multicolumn{15}{|l|}{ Rhopalondendrina igen. nov. } \\
\hline R. avis igen. et isp. nov.* & $\mathrm{T}$ & & $\mathrm{N}$ & & & & & & & $\mathrm{N}$ & & & & \\
\hline R. acanthina igen. et isp. nov. & & & $\mathrm{T}$ & & & & & & & $\mathrm{P} ?$ & & & & \\
\hline P. contra igen. et isp. nov. & & & $\mathrm{T}$ & & & & & & & & & & & \\
\hline P. tigris igen. et isp. nov. & & & $\mathrm{T}$ & & & & & & & & & & & \\
\hline \multicolumn{15}{|l|}{ Antodendrina igen. nov. } \\
\hline A. ligula igen. et isp. nov.* & & & $\mathrm{T}$ & & & & & & & & & & & \\
\hline Total number per substrate type ${ }^{* *}$ : & 12 & 3 & 21 & 4 & 15 & 5 & 4 & 1 & 7 & 4 & 1 & 2 & 2 & 1 \\
\hline
\end{tabular}




\section{Evolutionary patterns of dendrinid microborings}

The final aspect of the present discussion illuminates ichnodiversity patterns of dendrinid microborings through geologic time and compares this record to published diversity curves for bioerosion ichnotaxa (Fig. 33). The stratigraphical range and actual records of the revised suite of dendrinid ichnotaxa, including two levels of uncertainty, are compiled in Table 6. The resulting curves for the ichnospecies richness, and for the number of ichnotaxa that make their first appearance per period or series, are shown in Figure 33A. These curves are based on the actual certain records and ranges in-between. However, including also those ranges that are delineated by uncertain end members would result in
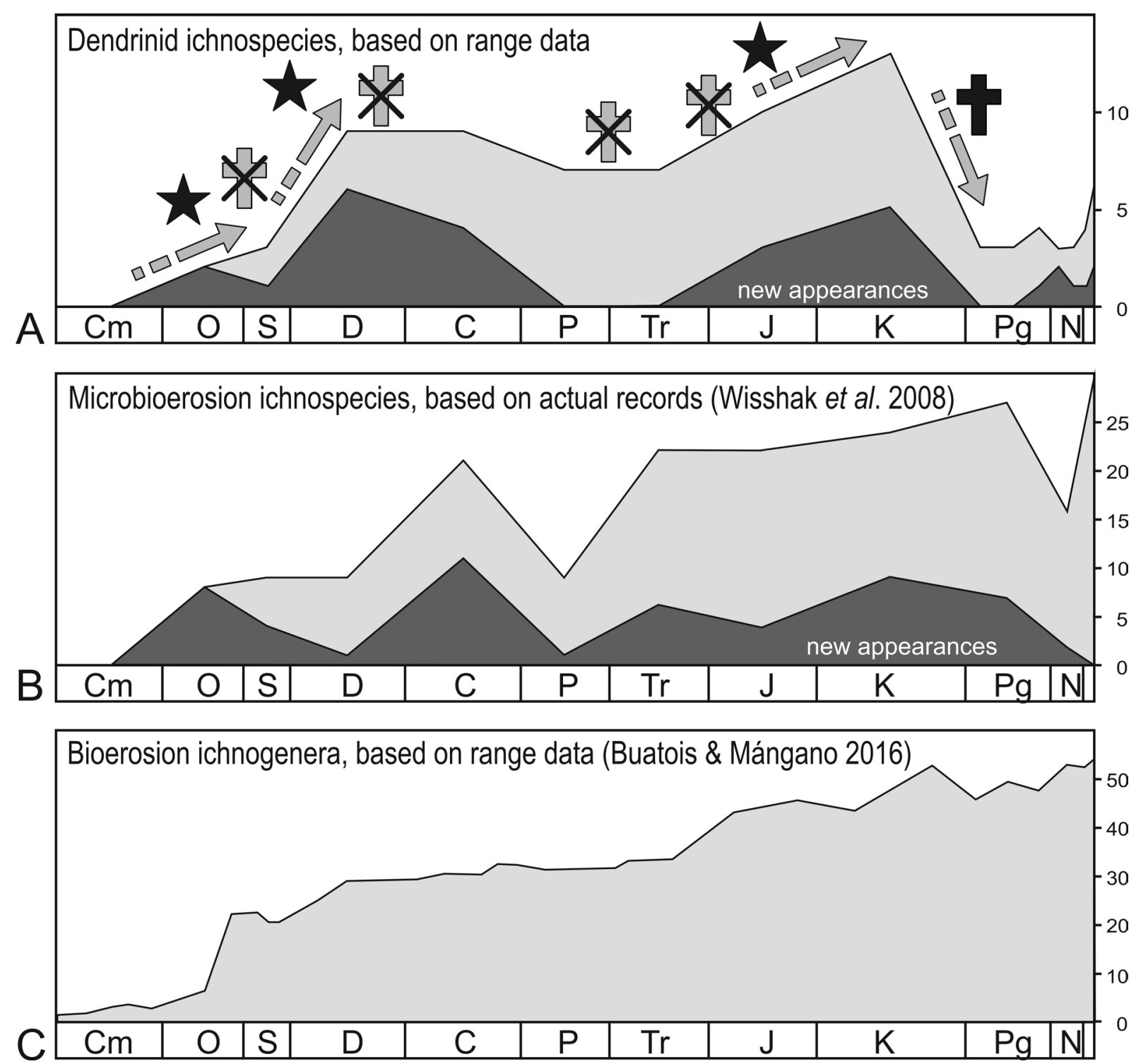

Fig. 33. A. Evolutionary trends in dendrinid microborings, considering the known range (based on certain end members only) of the various ichnospecies (light grey) and the number of ichnospecies making their first appearance (dark grey). Numbers are per period, except for the Paleocene to Pleistocene (global series). Relevant evolutionary radiations and extinction events are indicated. B. Same graph for all microbioerosion ichnospecies, but based on actual records only (data from Wisshak et al. 2008; numbers per period). C. Ichnodiversity curve for all bioerosion ichnogenera based on range data (data from Buatois \& Mángano 2016; numbers per global series). 
Table 6. Revised suite of ichnotaxa and their stratigraphical range in the Phanerozoic. $\mathrm{T}=$ occurrence of holotype; $\mathrm{P}=$ published occurrence; $\mathrm{N}=$ new occurrence; ? = uncertain record; - - = occurrence inferred from older or younger records; -?- = uncertain occurrence inferred from uncertain older or younger records; $*=$ type ichnospecies; $* *=$ certain or inferred from certain occurrences only.

\author{
Ichnotaxon \\ Dendrina Quenstedt, 1849 \\ D. dendrina (Morris, 1851) comb. nov.* \\ D. belemniticola Mägdefrau, 1937 \\ D. lacerata Hofmann, 1996 \\ Clionolithes Clarke, 1908 \\ C. radicans Clarke, 1908* \\ C. palmatus Clarke, 1908 \\ C. pannosus (Solle, 1938) comb. nov. \\ C. cervicornis (Vogel et al., 1987) \\ C. alcicornis (Vogel et al., 1987) comb. nov. \\ C. convexus (Hofmann, 1996) comb. nov. \\ Calcideletrix Mägdefrau, 1937 \\ C. flexuosa Mägdefrau, 1937* \\ C. breviramosa Mägdefrau, 1937 \\ C. anomala (Mägdefrau, 1937) comb. nov. \\ C. fastigata (Radtke, 1991) comb. nov.
}

Dictyoporus Mägdefrau, 1937

D. nodosus Mägdefrau, 1937*

D. balani (Tavernier et al., 1992) comb. nov. Abeliella Mägdefrau, 1937

A. riccioides Mägdefrau, 1937*

A. procera Mägdefrau, 1937

Nododendrina Vogel et al., 1987

N. europaea (Fischer, 1875) comb. nov.

$N$. incomposita (Mägdefrau, 1937) comb. nov.

N. paleodendrica (Elias, 1957) comb. nov.

N. nodosa Vogel et al., 1987*

Pyrodendrina Tapanila, 2008

P. cupra Tapanila, 2008*

P. arctica isp. nov.

P. belua isp. nov.

$P$. villosa isp. nov.

Rhopalondendrina igen. nov.

$R$. avis igen. et isp. nov.*

$R$. acanthina igen. et isp. nov.

$P$. contra igen. et isp. nov.

$P$. tigris igen. et isp. nov.

Antodendrina igen. nov.

A. ligula igen. et isp. nov.*

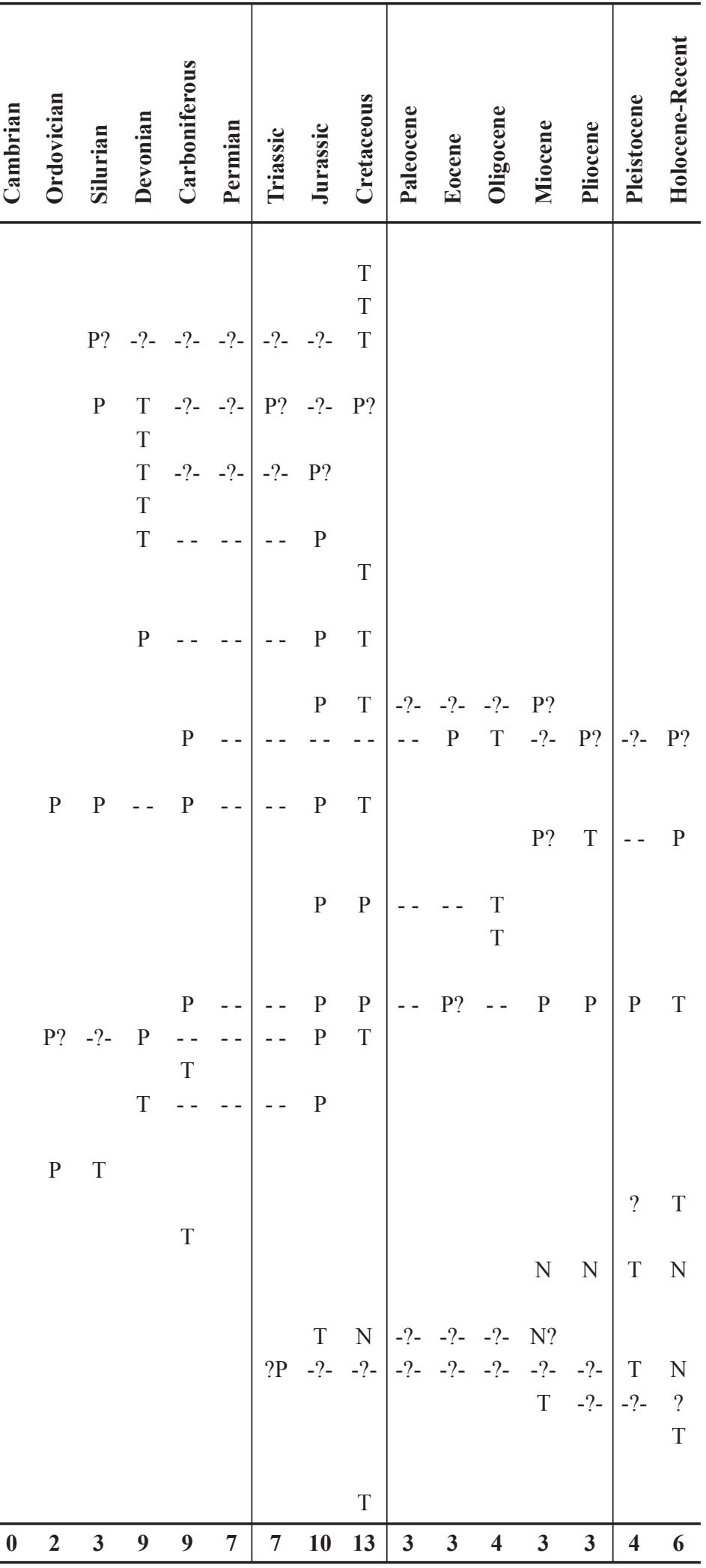


the same pattern, whereas a curve computed from actual records only (without inferred ranges) would be more prone to sampling artefacts, for instance in the Permian and Triassic periods, which both are understudied with respect to bioerosion and have not yielded unequivocal dendrinid records to date. This drawback is evident also in the curves compiled for all microbioerosion ichnospecies by Wisshak et al. (2008; plotted in Fig. 33B). While the latter compilation is still a valuable source for comparison, it needs to be stressed that it is already somewhat outdated due to the establishment of a substantial number of new microbioerosion ichnotaxa during the past decade and not least because it predates the present revision of the comparatively diverse Dendrinidae. Establishing ichnodiversity curves at the ichnospecies level is important for the interpretation of evolutionary patterns, as most recently stressed by Buatois \& Mángano (2016), whose ichnodiversity curve (plotted in Fig. 33C) was compiled at the ichnogenus level only, with the drawback of masking extinction events, which are more prominent at the ichnospecies level. Nevertheless, this curve provides an excellent and up-to-date picture of bioerosion ichnodiversity through the Phanerozoic, with the added value of a relatively good temporal resolution. It should be noted that in the case of the dendrinids, the present data set allows us to examine the evolutionary trends of a certain type of microbioerosion traces independent of ichnodisparity, because all dendrinids fall within the same category of architectural designs ("dendritic and rosetted borings") as defined by Buatois et al. (2017).

Focusing on adaptive radiations of dendrinid microborers and their behavioural patterns, which can to a certain extent be inferred from the ichnodiversity of their microbioerosion traces, a strong two phase rise in ichnospecies richness follows the first occurrence of dendrinids in the Ordovician and lasts until the Devonian, were nine ichnospecies are recorded. The first part of this increase in dendrinid ichnodiversity can be interpreted as a result of the "Great Ordovician Biodiversification Event" sensu Webby et al. (2004) and the contemporaneous "Ordovician Bioerosion Revolution" sensu Wilson \& Palmer (2006). This increase is also apparent from the total microbioerosion ichnospecies curve of Wisshak et al. (2008; Fig. 33B) and it is the most remarkable radiation seen in the total marine bioerosion ichnogenera curve of Buatois \& Mángano (2016; Fig. 33C). The second part of the radiation, from the Silurian to the Devonian, probably reflects the "Mid-Palaeozoic Precursor of the Mesozoic Marine Revolution" sensu Signor \& Brett (1984). It coincides with another, albeit less pronounced, increase in the number of bioerosion ichnogenera in a graph shown in Buatois \& Mángano 2016 (here as Fig. 33C), and it closely correlates with the doubling in macrobioerosion ichnogenera reported by Wilson (2007: fig. 20.11). The graph for microbioerosion ichnospecies (Fig. 33B) would imply a delayed corresponding radiation in the Devonian to the Carboniferous, but this offset could as well represent a sampling bias resulting from the limited amount of microbioerosion studies on Devonian material. In any case, these Early- to Mid-Palaeozoic adaptive radiations can be interpreted as a reflection of the increased predation pressure and consequent infaunalisation and, as Wilson (2007) pointed out, these radiations were also linked to a marked general increase in the degree of bioerosion in calcareous substrates. The next distinct diversification of dendrinid microborings is recorded for the Mesozoic, with nearly a doubling in ichnodiversity from 7 ichnospecies in the Triassic to a peak level of 13 ichnospecies in the Cretaceous period. This increase is interpreted as a reaction to the elevated predation pressure and further infaunalisation that took place during the "Marine Mesozoic Revolution" sensu Vermeij (1977). While this radiation is not evident for the complete spectrum of microbioerosion ichnospecies (Fig. 33B), it is clearly reflected in the total bioerosion ichnogenera curve (Fig. 33C), as well as by a marked increase in the number of macroborer ichnogenera from the Triassic to the Jurassic (Wilson 2007: fig. 20.11). In conclusion, up to the Mesozoic the ichnodiversity pattern of dendrinid microborings quite closely mimics that of overall microboring and macroboring ichnotaxa. This picture, however, changes drastically when considering the Cenozoic record: whereas the curves for microbioerosion ichnospecies (Fig. 33B), the microbioerosion ichnogenera (Wilson 2007: fig 20.11) and for total bioerosion ichnogenera (Fig. 33C) suggest a leveling off in ichnodiversity, the dendrinid ichnodiversity shows a strong drop at the transition to the Cenozoic, and the number of recorded ichnotaxa remains low. 
There is a slight recovery towards the Holocene/Recent, which is probably a sampling artefact due to the relatively large number of bioerosion studies in modern seas.

These patterns shift the perspective from radiations towards extinction events that might have affected the tracemakers of dendrinid microborings. First of all, it is remarkable that until the late Mesozoic, none of the "Big Five" extinction events, including the most severe end-Permian mass-extinction ( $>90 \%$ extinction in marine invertebrate species), appears to have had any noticeable effect on dendrinids (Fig. 33A). This stands in strong contrast to the pattern seen for the end-Cretaceous mass extinction, where a drop from the peak ichnodiversity of 13 ichnospecies to a mere 3 ichnospecies is recorded (a 77\% drop), and thus one third of all known dendrinid ichnospecies make their last appearance in the Cretaceous period. The end-Cretaceous extinction event is also the only detectable extinction event (13\% drop) in the bioerosion ichnogenus ichnodiversity curve (Fig. 33C), whereas none of the extinction events were apparent from the microbioerosion ichnodiversity curve (Fig. 33B). The reason for this differential effect of extinction events on dendrinid microborings, and on bioeroders in general, offers a promising line of future research beyond the scope of the present study. For instance, among the most probable suspects of dendrinid microboring tracemakers (see above), at least the sponges are filter feeders and the foraminiferans might be as well (many benthic foraminiferans settling on elevated hardsubstrates on the seafloor are considered suspension feeders). Such suspension feeders are known to be more strongly affected by extinction events, providing a possible explanation for extinctions among the dendrinids, but it remains puzzling why only a sole extinction event was detrimental to them. Answers could be found in a comparison with evolutionary trends seen in groups of bioerosion ichnotaxa that are produced by tracemakers with other trophic modes, such as microborings by photoautotrophic euendoliths, organotrophic grazers, and so forth. Differences in the buffering capacity of various groups of endolithic bioeroders, such as the evolutionary longevity of microendoliths (Vogel \& Glaub 2004), are also relevant in this context. Considering co-extinction with preferred substrate species would be another line of reasoning - in the present case the demise of belemnites and many other molluscs at the end-Cretaceous extinction event. In any case, a solid ichnotaxonomy of the data set underlying the analysis of evolutionary trends seen in bioerosion trace fossils is paramount.

\section{Acknowledgements}

This study depended on the highly appreciated support of colleagues world-wide, who handled collection inquiries, provided images of type material, arranged loans, or facilitated visits of their collections: Rainer Brocke, Gunnar Riedel, Ulrich Jansen, Erika Scheller-Wagner, Joachim Scholz, Silviu Martha and Philipe Havlik (all Senckenberg, Frankfurt, Germany), Franzisca Lehmann (Geologischer Dienst NRW, Krefeld, Germany), Gudrun Radtke (Hessisches Landesamt für Naturschutz, Umwelt und Geologie, Wiesbaden, Germany), Ingrid Glaub (Hanau, Germany), Christian Neumann (Museum für Naturkunde, Berlin, Germany), Norbert Hauschke (Institut für Geowissenschaften und Geographie, Halle, Germany), AlexanderNützel(Bayerische Staatssammlung fürPaläontologieundGeologie, Munich, Germany), Ulrich Kothoff (Institut für Geologie, Hamburg, Germany), Markus Wilmsen (Senckenberg Naturhistorische Sammlungen, Dresden, Germany), Andreas Kroh (Naturhistorisches Museum, Vienna, Austria), Tim Palmer (Institute of Geography and Earth Sciences, Aberystwyth, UK), Paul Taylor and Consuelo Sendino (Natural History Museum, London, UK), Pierre Moissette (Laboratoire de Géologie, Lyon, France), Vienet Bernard (Museum de Gray, Gray, France), Sylvain Charbonnier (Muséum national d'Histoire naturelle, Paris, France), Olivier Maridet (Jurassica, Porrentruy, Switzerland), Ursula Menkveld-Gfeller (Naturhistorisches Museum der Burgergemeinde, Bern, Switzerland), Ed Landing (New York State Museum, Albany, New York, USA), Tiffany Adrain (Department of Earth and Environmental Sciences, Iowa City, Iowa, USA), Albert Kollar (Carnegie Museum of Natural History, Pittsburgh, Pennsylvania, USA), Dan Levin (Smithsonian Institution, National Museum of Natural History, Washington DC, USA), James Schiffbauer (Department of Geological Sciences, Columbia, Missouri, USA), Rolf 
Schmidt (Museum Victoria, Melbourne, Australia), Michelle Coyne (Geological Survey of Canada, Ottawa, Ontario, Canada), Kantimati G. Kulkarni (Museum of Geology and Palaeontology, Pune, India), Andrew Knoll (Harvard University, Cambridge, Massachusetts, USA). I am indebted to André Freiwald (Senckenberg am Meer, Wilhelmshaven, Germany), Peter Girod (Berlin, Germany) and Ingrid Glaub (Hanau, Germany) for providing material from their collections and for sharing valuable observations. Sebastian Teichert (GeoZentrum Nordbayern, Erlangen, Germany) is acknowledged for solving issues of ancient Greek and Latin syntax, and Markus Bertling (Geomuseum der Universität Münster, Münster, Germany), Dirk Knaust (Statoil ASA, Stavanger, Norway), Kei Matsuyama (Senckenberg am Meer, Wilhelmshaven, Germany) and Andreas Kroh (Naturhistorisches Museum, Vienna, Austria) are thanked for fruitful discussions related to ICZN matters and ichnotaxonomical principles. Last but not least, I am grateful to Dirk Knaust and an anonymous referee for delving into this extensive ichnotaxonomical revision and providing critical reviews.

\section{References}

Bernard-Dumanois A. \& Delance J.-H. 1983. Microperforations par algues et champignons sur les coquilles des "Marnes à Ostrea acuminata" (Bajocien supérieur) de Bourgogne (France), relations avec le milieu et utilisation paléobathymétrique. Geobios 16: 419-429.

https://doi.org/10.1016/S0016-6995(83)80102-8

Bertling M., Braddy S.J., Bromley R.G., Demathieu G.D., Genise J., Mikulás R., Nielsen J.K., Nielsen K.S.S., Rindsberg A.K., Schlirf M. \& Uchman A. 2006. Names for trace fossils: a uniform approach. Lethaia 39: 265-286. https://doi.org/10.1080/00241160600787890

Beuck L. 2008. Framework-Building Cold-Water Coral Ecosystem Characterisation: Key Studies from Macro- to Micro-Scale. Unpublished Diploma Thesis. Friedrich-Alexander Universität, ErlangenNürnberg, Germany.

Beuck L. \& Freiwald A. 2005. Bioerosion patterns in a deep-water Lophelia pertusa (Scleractinian) thicket (Propeller Mound, northern Porcupine Seabight). In: Freiwald A. \& Roberts J.M. (eds) ColdWater Corals and Ecosystems: 915-936. Springer, Heidelberg.

https://doi.org/10.1007/3-540-27673-4_47

Beuck L., Freiwald A. \& Taviani M. 2010. Spatiotemporal bioerosion patterns in deep-water scleractinians from off Santa Maria di Leuca (Apulia, Ionian Sea). Deep-Sea Research II 57: 458-470.

https://doi.org/doi:10.1016/j.dsr2.2009.08.019

Blissett D.J. \& Pickerill R.K. 2004. Observations on macroborings from the White Limestone Group of Jamaica. Cainozoic Research 3: 167-187.

Blissett D.J. \& Pickerill R.K. 2007. Systematic ichnology of microborings from the Cenozoic White Limestone Group, Jamaica, West Indies. Scripta Geologica 134: 77-108.

Boekschoten G.J. 1966. Shell borings of sessile epibiontic organisms as palaeoecological guides (with examples from the Dutch coast). Palaeogeography, Palaeoclimatology, Palaeoecology 2: 333-379. https://doi.org/10.1016/0031-0182(66)90023-X

Botquelen A. \& Mayoral E. 2005. Early Devonian bioerosion in the Rade de Brest, Armorican Massif, France. Palaeontology 48: 1057-1064. https://doi.org/10.1111/j.1475-4983.2005.00492.x

Branson C.C. 1937. Stratigraphy and fauna of the Sacajawea Formation, Mississippian, of Wyoming. Journal of Paleontology 11: 650-660.

Breton G., Wisshak M., Néraudeau D. \& Morel N. 2017. Parasitic gastropod bioerosion trace fossil on Cenomanian oysters from Le Mans, France and its ichnologic and taphonomic context. Acta Palaeontologica Polonica 62: 45-57. https://doi.org/10.4202/app.00304.2016 
Bromley R.G. 2004. A stratigraphy of marine bioerosion. In: McIlroy D. (ed.) The Application of Ichnology to Palaeoenvironmental and Stratigraphic Analysis: 455-481. Geological Society Special Publications 228. Geological Society, London.

Bromley R.G. 2005. Preliminary study of bioerosion in the deep-water coral Lophelia, Pleistocene, Rhodes, Greece. In: Freiwald A. \& Roberts J.M. (eds) Cold-Water Corals and Ecosystems: 895-914. Springer, Heidelberg. https://doi.org/10.1007/3-540-27673-4_46

Bromley R.G. \& D‘Alessandro A. 1984. The ichnogenus Entobia from the Miocene, Pliocene and Pleistocene of southern Italy. Rivista Italiana de Paleontologia e Stratigrafia 90: 227-296.

Bromley R.G. \& Nielsen K.S.S. 2015. Bioerosional ichnotaxa and the fossilization barrier. Annales Societatis Geologorum Poloniae 85: 453-455. https://doi.org/10.14241/asgp.2015.033

Bromley R.G. \& Surlyk F. 1973. Borings produced by brachiopod pedicles, fossil and Recent. Lethaia 6: 349-365. https://doi.org/10.1111/j.1502-3931.1973.tb01203.x

Bromley R.G., Wisshak M., Glaub I. \& Botquelen A. 2007. Ichnotaxonomic review of dendriniform borings attributed to foraminiferans: Semidendrina igen. nov. In: Miller III W. (ed.) Trace Fossils: Concepts, Problems, Prospects: 518-530. Elsevier, Amsterdam.

https://doi.org/10.1016/B978-044452949-7/50158-3

Buatois L.A. \& Mángano M.G. 2016. Recurrent patterns and processes: The significance of ichnology in evolutionary paleoecology. In: Mángano M.G. \& Buatois L.A. (eds) The Trace-Fossil Record of Major Evolutionary Events, Vol 2: 449-473, Topics in Geobiology 40. Springer, Heidelberg.

Buatois L.A., Wisshak M., Wilson M.A. \& Mángano M.G. 2017. Categories of architectural designs in trace fossils: A measure of ichnodisparity. Earth Science Reviews 164: 102-181.

https://doi.org/10.1016/j.earscirev.2016.08.009

Bublichenko N.L. 1958. Some new representatives of Devonian and Carboniferous brachiopods from Rudno-Alta and Sary-Arka. Izvestiya Akademii Nauk Kazakhskoi SSR 1956, Seriya Geologicheskaya 23: 93-104.

Budd D.A. \& Perkins R.D. 1980. Bathymetric zonation and paleoecological significance of microborings in Puerto Rican shelf and slope sediments. Journal of Sedimentary Petrology 50: 881-904.

Bundschuh M. 2000. Silurische Mikrobohrspuren: Ihre Beschreibung und Verteilung in verschiedenen Faziesräumen (Schweden, Litauen, Großbritannien und USA). Unpublished $\mathrm{PhD}$ Thesis. Johann Wolfgang Goethe-Universität, Frankfurt am Main, Germany.

Cherchi A. \& Schroeder R. 1991. Perforations branchues dues à des Foraminifères cryptobiotiques dans des coquilles actuelles et fossiles. Comptes rendus de l'Académie des Sciences 312: 111-115.

Clarke J.M. 1908. The beginnings of dependent life. New York State Museum Bulletin 121: 146-169.

Clarke J.M. 1921. Organic dependence and disease, their origin and significance. New York State Museum Bulletin 221-222: 1-113.

Dacqué E. 1921. Vergleichende biologische Formenkunde der fossilen niederen Tiere. Borntraeger, Berlin.

Easton W.H. 1962. Carboniferous formations and faunas of central Montana. Geological Survey Professional Paper 348. United States Government Printing Office, Washington DC.

Edwards B.D. \& Perkins R.D. 1974. Distribution of microborings within continental margin sediments of the southeastern United States. Journal of Sedimentary Petrology 44: 1122-1135.

Ekdale A.A. \& Bromley R.G. 1984. Comparative ichnology of shelf-sea and deep-sea chalk. Journal of Paleontology 58: 322-332. 
Elias M.K. 1957. Late Mississippian fauna from the Redoak Hollow Formation of southern Oklahoma, part I. Journal of Paleontology 31: 370-427.

Elias R.J. 1980. Borings in solitary rugose corals of the Selkirk Member, Red River Formation (late Middle or Upper Ordovician), southern Manitoba. Canadian Journal of Earth Sciences 17: 272-277. https://doi.org/10.1139/e80-023

Elsik W.C. 1966. Biologic degradation of fossil pollen grains and spores. Micropaleontology 12: 515518.

Elsik W.C. 1971. Microbiological degradation of sporopollenin. In: Brooks J. et al. (eds) Sporopollenin: 480-511. Academic Press, London.

Esmerode E.V., Lykke-Andersen H. \& Surlyk F. 2007. Ridge and valley systems in the Upper Cretaceous chalk of the Danish Basin: contourites in an epeiric sea. Geological Society, London, Special Publications 276: $265-282$.

Étallon A. 1859a. Études paléontologiques sur le Haut-Jura: rayonnés du corallien. Mémoires de la Société d'Émulation du Départment du Doubs, Série 3 3: 401-553.

Étallon A. 1859b. Sur la classification des spongiaires du Haut-Jura et leur distribution dans les étages. Actes de la Société Jurassienne d'Émulation 9: 129-160.

Étallon A. 1862. Études paléontologiques sur la Haut-Jura. Monographie du corallien. Vertébrés, articulés, mollusques (Séances des 8 janvier et 12 mars 1859). Mémoires de la Societé d'Emulation du Département de Doubs, Série 3 6: 53-260.

Étallon A. 1864. Études paléontologiques sur le Jura graylois: terrains jurassiques moyen et supérieur. Mémoires de la Societé d'Emulation du Département de Doubs, Série 3 8: 221-506.

Färber C., Wisshak M., Pyko I., Bellou N. \& Freiwald A. 2015. Effects of water depth, seasonal exposure, and substrate orientation on microbial bioerosion in the Ionian Sea (Eastern Mediterranean). PLoS One 10: e0126495. https://doi.org/10.1371/journal.pone.0126495

Fenton C.L. \& Fenton M.A. 1932. Boring sponges in the Devonian of Iowa. American Midland Naturalist 13: 42-54.

Fischer M.P. 1875. D’un type de sarcodaires. Journal de Zoologie 4: 530-533.

Fischer M.P. 1876. On the presence in existing seas of a type of Sarcodaria of the secondary formations. The Annals and Magazine of Natural History 17: 103-104.

https://doi.org/10.1080/00222937608681910

Försterra G., Beuck L., Häussermann V. \& Freiwald A. 2005. Shallow-water Desmophyllum dianthus (Scleractinia) from Chile: characteristics of the biocoenoses, the bioeroding community, heterotrophic interactions and (paleo)-bathymetric implications. In: Freiwald A. \& Roberts J.M. (eds) Cold-Water Corals and Ecosystems: 937-977. Springer, Heidelberg. https://doi.org/10.1007/3-540-27673-4_48

Fries E. 1832. Systema Mycologicum, Sistens Fungorum, Ordines, Genera et Species, huc usque Cognitas, quas ad Normam Methoi Naturalis, III. Sumtibus Ernesti Mauritii, Greifswald.

Fritsch A. 1908. Problematica Silurica. Reimund Gerhard, Prague.

Furlong C.M. \& McRoberts C.A. 2014. Commensal borings from the Middle Devonian of central New York: Ecologic and taxonomic review of Clionoides, Clionolithes, and Canaliparva n. ichnogen. Journal of Paleontology 88: 130-144. https://doi.org/10.1666/12-141

Geinitz H.-B. 1849. Das Quadersandsteingebirge oder Kreidegebirge in Deutschland. Craz \& Gerlach, Freiberg. 
Ghare M.A. 1982. Borings on belemnoid rostra from Utatur Group of Upper Cretaceous rocks of Trichinopoly District, Tamil Nadu. Journal of the Geological Society of India 23: 129-135.

Girod P. \& Rösner T. 2013. Spurenfossilien (Ichnofossilien). In: Arbeitskreis Paläontologie Hannover (eds) Fossilien aus dem Campan von Hannover: 280-288. Arbeitskreis Paläontologie Hannover, Hannover.

Glaub I. 1988. Mikrobohrspuren in verschiedenen Faziesbereichen des Oberjura Westeuropas (vorläufige Mitteilungen). Neues Jahrbuch für Geologie und Paläontologie, Abhandlungen 177: 135-164.

Glaub I. 1994. Mikrobohrspuren in ausgewählten Ablagerungsräumen des europäischen Jura und der Unterkreide (Klassifikation und Palökologie). Courier Forschungsinstitut Senckenberg 174: 1-324.

Glaub I. 2004. Recent and sub-recent microborings from the upwelling area off Mauritania (West Africa) and their implications for palaeoecology. In: McIlroy D. (ed.) The Application of Ichnology to Palaeoenvironmental and Stratigraphic Analysis: 63-77. Geological Society, London, Special Publications 228 .

Glaub I. \& Schmidt H. 1994. Traces of endolithic microboring organisms in Triassic and Jurassic bioherms. Kaupia 4: 103-112.

Glaub I., Golubic S., Gektidis M., Radtke G. \& Vogel K. 2007. Microborings and microbial endoliths: Geological implications. In: Miller III W. (ed.) Trace Fossils: Concepts, Problems, Prospects: 368-381. Elsevier, Amsterdam. https://doi.org/10.1016/B978-044452949-7/50147-9

Goette A. 1916. Die Gattungen Podocoryne, Stylactis and Hydractinia. Zoologische Jahrbücher 39: $443-510$.

Gravesen P. \& Jakobsen S.L. 2011. Skrivekridtets Fossiler. Gyldendahl A/S, Copenhagen.

Günther A. 1990. Distribution and bathymetric zonation of shell-boring endoliths in recent reef and shelf environments: Cozumel, Yucatan (Mexico). Facies 22: 233-262.

Hagenow F. von 1840. Monographie der Rügen'schen Kreide-Versteinerungen, II. Abtheilung: Radiarien und Annulaten. Nebst Nachträgen zur ersten Abtheilung. Neues Jahrbuch für Mineralogie, Geognosie, Geologie und Petrefakten-Kunde 1840: 630-672.

Hancock A. 1849. On the excavating powers of certain sponges belonging to the genus Cliona; with descriptions of several new species, and an allied generic form. Annals and Magazine of Natural History, Series 2 3: 321-348. https://doi.org/10.1080/03745485909494773

Häntzschel W. 1962. Trace fossils and problematica. In: Moore R.C. (ed.) Treatise on Invertebrate Paleontology, Part W-Miscellanea: W177-245. University of Kansas Press, Lawrence.

Häntzschel W. 1975. Trace fossils and problematica. In: Moore R.C. (ed.) Treatise on Invertebrate Paleontology, Part W-Miscellanea, Supplement 1: W1-269. University of Kansas Press, Lawrence.

Higazi F. 1985. Kleinfaunen aus dem Oberjura des spanischen Keltiberikums mit spezieller Berücksichtigung der Paläoökologie. Arbeiten aus dem Institut für Geologie und Paläontologie der Universität Stuttgart, Neue Folge 82: 127-159.

Hillmer G. \& Schulz M. 1973. Ableitung der Biologie und Ökologie eines Polychaeten der Oberkreide durch Analyse des Bohrganges Ramosulcichnus biforans (Gripp) nov. ichnogen. Mitteilungen aus dem Geologisch-Paläontologischen Institut der Universität Hamburg 42: 5-24.

Hofmann K. 1996. Die mikro-endolithischen Spurenfossilien der borealen Oberkreide NordwestEuropas und ihre Faziesbeziehungen. Geologisches Jahrbuch, Serie A 136: 1-151. 
Hofmann K. \& Vogel K. 1992. Endolithische Spurenfossilien in der Schreibkreide (Maastricht) von Rügen (Norddeutschland). Zeitschrift für Geologische Wissenschaften 20: 51-65.

Höpner S. \& Bertling M. 2017. Holes in bones: ichnotaxonomy of bone borings. Ichnos. https://doi.org/10.1080/10420940.2017.1289937

Hoşgör I. \& Košt'ák M. 2012. Occurrence of the Late Cretaceous belemnite Belemnitella in the Arabian Plate (Hakkari, SE Turkey) and its palaeogeographic significance. Cretaceous Research 37: 35-42. https://doi.org/10.1016/j.cretres.2012.02.014

Hyde J.E. 1953. Mississippian Formations of Central and Southern Ohio. Bulletin 51. Ohio Division of Geological Survey, Columbus.

ICZN (International Commission for Zoological Nomenclature) 1999. International Code of Zoological Nomenclature, adopted by the International Union of Biological Sciences, $4^{\text {th }}$ edition. International Trust for Zoological Nomenclature, London.

Kaminski M.A. 2001. The new and reinstated genera of agglutinated foraminifera published between 1986 and 1996. In: Hart M.B., Kaminski M.A. \& Smart C.W. (eds) Proceedings of the Fifth International Workshop on Agglutinated Foraminifera. Grzybowski Foundation Special Publication 7: 185-219.

Kennedy W. 1970. Trace fossils in the Chalk environment. In: Frey R.W. (ed.) The Study of Trace Fossils: 377-396. Springer, New York.

Klug C., Kröger B., Korn D., Rücklin M., Schemm-Gregory M., De Baets K. \& Mapes R.H. 2008. Ecological change during the early Emsian (Devonian) in the Tafilalt (Morocco), the origin of the Ammonoidea, and the first African pyrgocystid edrioasteroids, machaerids and phyllocarids. Palaeontographica, Abteilung A 283: 83-176. https://doi.org/10.1127/pala/283/2008/83

Knaust D. 2012. Trace fossil systematics. In: Knaust D. \& Bromley R.G. (eds) Trace Fossils as Indicators of Sedimentary Environments: 79-102. Elsevier, Amsterdam.

https://doi.org/10.1016/B978-0-444-53813-0.00003-4

Kölliker A. von 1860. Über das ausgebreitete Vorkommen von pflanzlichen Parasiten in den Hartgebilden niederer Thiere. Zeitschrift für wissenschaftliche Zoologie 10: 215-232.

Košt'ák M. 2004. Short ichnofossil synopsis in Upper Cretaceous belemnite family Belemnitellidae from central and eastern Europe. In: Mikulas R. (ed.) Abstract Book, $4^{\text {th }}$ international bioerosion workshop, Prague, August 30-September 3, 2004. Institute of Geology, Academy of Sciences of the Czech Republic, Prague.

Krause G., Meincke J. \& Schwarz H.J. 1991. Scientific cruise reports of Arctic expeditions ARK VI/1-4 of RV "Polarstern" in 1989. Berichte zur Polarforschung 87: 1-110.

Kutscher M. 1972. Fossile Lebensspuren in der weißen Schreibkreide (Unter-Maastricht) der Insel Rügen. Aufschluß 23: 26-34.

Lees J.H. \& Thomas A. 1918. The Ste. Genevieve Marls near Fort Dodge and their fauna. Proceedings of the Iowa Academy of Science 25: 599-616.

Lindström M. 1979. Probable sponge borings in Lower Ordovician limestone of Sweden. Geology 7 : $152-155$.

Loeblich A.R. \& Tappan H. 1964. Sarcodina, chiefly "Thecamoebians" \& Foraminiferida. In: Moore R.C. (ed) Treatise on Invertebrate Paleontology, Part C-Protista/Protoctista 2. University of Kansas Press, Lawrence.

Mägdefrau K. 1937. Lebensspuren fossiler "Bohr"-Organismen. Beiträge zur naturkundlichen Forschung in Südwestdeutschland 2: 54-67. 
Marcinowski R. 1972. Belemnites of the genus Actinocamax Miller, 1823, from the Cenomanian of Poland. Acta Geologica Polonica 22: 247-256.

Mayoral E. 1988. Microperforaciones (Tallophyta) sobre Bivalvia del Plioceno del Bajo Guadalquivir. Importancia paleoecologica. Estudios Geologicos 44: 301-316.

Miller J.S. 1826. Observations on the genus Actinocamax. Transactions of the Geological Society of London, Second Series 2 2: 63-68. https://doi.org/10.1144/transgslb.2.1.63

Morris J. 1851. Palaeontological notes. Annals and Magazine of Natural History, Series 2 8: 85-90. https://doi.org/10.1080/03745486109494965

Müller J. 1851. Monographie der Petrefacten der Aachener Kreideformation. Henry \& Cohen, Bonn.

Nadjin D.P. 1969. Morfologia i Paleobiologia Verkhnemelovykh Belemnitov. Moscow.

Nestler H. 1975. Die Fossilien der Rügener Schreibkreide. Die neue Brehm Bücherei 486. Ziemsen, Wittenberg Lutherstadt.

Palmer T.J. \& Palmer C.D. 1977. Faunal distribution and colonization strategy in a Middle Ordovician hardground community. Lethaia 10: 179-199. https://doi.org/10.1111/j.1502-3931.1977.tb00608.x

Pereira S., Mocho P. \& Lourenço J. 2009. Bioerosion on Megacardita jouanetti (Bivalvia) from the Miocene of Foz do Rego (Costa de Caparica, Portugal). Paleolusitana 1: 327-338.

Pictet F.J. 1857. Traité de Paléontologie ou Histoire naturelle des Animaux fossiles considérés dans leurs Rapports zoologiques et geologiques. Vol. 4. J.-B. Bailliére et Fils, London.

Plewes C.R. 1996. Ichnotaxonomic Studies of Jurassic Endoliths. Unpublished PhD Thesis. University of Wales, Aberystwyth, UK.

Plewes C.R., Palmer T. \& Haynes J. 1993. A boring foraminiferan from the Upper Jurassic of England and Northern France. Journal of Micropalaeontology 12: 83-89. https://doi.org/10.1144/jm.12.1.83

Pokorný R. \& Štofik M. 2016. Evidence of bioerosive structures in Quaternary glaciomarine sediments from southwestern Iceland. Ichnos. https://doi.org/10.1080/10420940.2016.1260567

Powers B.G. \& Ausich W.I. 1990. Epizoan associations in a lower Mississippian paleocommunity (Borden Group, Indiana, USA). Historical Biology 4: 245-265.

Pugaczewska H. 1965. Les organismes sédentaires sur les rostres des bélemnites du Crétacé supérieur. Acta Palaeontologica Polonica 10: 73-95.

Pugaczewska H. 1970. Traces of the activity of bottom organisms on the shells of the Jurassic ostreiform pelecypods of Poland. Acta Palaeontologica Polonica 15: 425-440.

Quenstedt F.A. 1849. Petrefaktenkunde Deutschlands - Die Cephalopoden. Ludwig Friedrich Fues, Tübingen, Germany.

Quenstedt F.A. 1885 Handbuch der Petrefaktenkunde. Verlag der H. Laupp'schen Buchhandlung, Tübingen.

Radtke G. 1991. Die mikroendolithischen Spurenfossilien im Alt-Tertiär West-Europas und ihre palökologische Bedeutung. Courier Forschungsinstitut Senckenberg 138: 1-185.

Radtke G. 1993. The distribution of microborings in molluscan shells from recent reef environments at Lee Stocking Island, Bahamas. Facies 29: 81-92. https://doi.org/10.1007/BF02536921

Radtke G., Glaub I., Vogel K. \& Golubic S. 2010. A new dichotomous microboring: Abeliella bellafurca isp. nov., distribution, variability and biological origin. Ichnos 17: 25-33.

https://doi.org/10.1080/10420940903358628 
Radwański A. 1972. Remarks on the nature of belemnicolid borings Dendrina. Acta Geologica Polonica 22: $257-264$.

Reich M. \& Frenzel P. 2002. Die Fauna und Flora der Rügener Schreibkreide (Maastrichtium, Ostsee). Archiv für Geschiebekunde 3: 73-284.

Rooney W.S. \& Perkins R.D. 1972. Distribution and geologic significance of microboring organisms within sediments of the Arlington Reef Complex, Australia. Geological Society of America Bulletin 83: 1139-1150. https://doi.org/10.1130/0016-7606(1972)83[1139:DAGSOM]2.0.CO;2

Rose C. 1855. On the discovery of parasitic borings in fossil fish scales. Transactions of the Microscopic Society of London, New Series 3: 7-12.

Rudolph F. 2014. “Nur” Donnerkeile. Der Geschiebesammler 47: 3-24.

Ruedemann R. 1925. The Utica and Lorraine Formations of New York. Part 2: systematic paleontology. New York State Museum Bulletin 262: 1-171.

Schmidt H. 1992. Mikrobohrspuren ausgewählter Faziesbereiche der tethyalen und germanischen Trias (Beschreibung, Vergleich und bathymetrische Interpretation). Frankfurter Geowissenschaftliche Arbeiten, Serie A 12: 1-228.

Schmidt H. \& Freiwald A. 1993. Rezente gesteinsbohrende Kleinorganismen des norwegischen Schelfs. Natur und Museum 123: 149-155.

Schnick H. 1992. Zum Vorkommen der Bohrspur Hyellomorpha microdendritica Vogel, Golubic \& Brett im oberen Obermaastricht Mittelpolens. Zeitschrift für Geologische Wissenschaften 20: 109-124.

Schulz W. 2003. Geologischer Führer für den norddeutschen Geschiebesammler. CW-Verlagsgruppe, Schwerin, Germany.

Seuss B., Wisshak M., Mapes R.H. \& Landman N.H. 2015. Syn-vivo bioerosion of Nautilus by endoand epilithic foraminiferans (New Caledonia and Vanuatu). PLoS One 10: e125558.

https://doi.org/10.1371/journal.pone.0125558

Seward A.C. 1898. Fossil Plants: a Text-Book for Students of Botany and Geology. Cambridge University Press, Cambridge.

Signor P.W. \& Brett C.E. 1984. The mid-Paleozoic precursor to the Mesozoic marine revolution. Palaeobiology 10: 229-245.

Siverson M. 1993. Maastrichtian squaloid sharks from southern Sweden. Palaeontology 36: 1-19.

Solle G. 1938. Die ersten Bohr-Spongien im europäischen Devon und einige andere Spuren. Senckenbergiana Lethaea 20: 154-178.

Stiller F. 2005. An Early Jurassic Talpina-dominated assemblage of borings in bivalve shells from southern Hunan, China, with remarks on the ichnogenus Talpina Hagenow, 1840. Acta Palaeontologica Sinica 44: 396-411.

Talent J.A. 1963. The Devonian of the Mitchell and Wentworth Rivers. Geological Survey of Victoria, Memoir 24: 1-118.

Tapanila L. 2005. Palaeoecology and diversity of endosymbionts in Palaeozoic marine invertebrates: trace fossil evidence. Lethaia 38: 89-99. https://doi.org/10.1080/00241160510013123

Tapanila L. 2006. Devonian Entobia borings from Nevada, with a revision of Topsentopsis. Journal of Paleontology 80 (4): 760-767. https://doi.org/10.1666/0022-3360(2006)80[760:DEBFNW]2.0.CO;2 
Tapanila L. 2008. The medium is the message: imaging a complex microboring (Pyrodendrina cupra igen. n., isp. n.) from the early Paleozoic of Anticosti Island, Canada. In: Wisshak M. \& Tapanila L. (eds) Current Developments in Bioerosion: 123-145. Springer, Heidelberg.

https://doi.org/10.1007/978-3-540-77598-0_7

Tavernier A. \& Golubic S. 1993. Pliocene microboring assemblages in shells of the Purissima Formation (Capitola, California). Bollettino della Società Paleontologica Italiana, Special Volume 1: 405-414.

Tavernier A., Campbell S.E. \& Golubic S. 1992. A complex marine shallow-water boring trace: Dendrorete balani $\mathrm{n}$. ichnogen. et ichnospec. Lethaia 25: 303-310.

https://doi.org/10.1111/j.1502-3931.1992.tb01399.x

Taylor P.D., Barnbrook J.A. \& Sendino C. 2013. Endolithic biota of belemnites from the Early Cretaceous Speeton Clay Formation of North Yorkshire, UK. Proceedings of the Yorkshire Geological Society 59: 227-245. https://doi.org/10.1144/pygs2013-336

Teichert C. 1945. Parasitic worms in Permian brachiopod and pelecypod shells in Western Australia. American Journal of Science 243: 197-209.

Thomas A.O. 1911. A fossil burrowing sponge from the Iowa Devonian. Bulletin from the Laboratories of Natural History of the State University of Iowa 6: 165-169.

Thurmann J. \& Étallon A. 1864. Lethea Bruntrutana ou études paléontologiques et stratigraphiques dur les terrains Jurassique supérieurs du Jura Bernois et en particulier des environs de Porrentruy. Nouveaux Mémoirs de la Société Helvetique des Sciences Naturelles 20: 355-500.

Thuy B., Kiel S., Dulai A., Gale A.S., Kroh A., Lord A.R., Numberger-Thuy L.D., Stöhr S. \& Wisshak M. 2014. First glimpse into Lower Jurassic deep-sea biodiversity: in situ diversification and resilience against extinction. Proceedings of the Royal Society B 281: e20132624.

https://doi.org/10.1098/rspb.2013.2624

Tiedt L. 1958. Die Nerineen der österreichischen Gosauschichten. Sitzungsberichte der Österreichischen Akademie der Wissenschaften 167: 483-517. https://doi.org/10.1007/978-3-662-26139-2

Titschack J., Joseph N., Fietzke J., Freiwald A. \& Bromley R.G. 2013. Record of a tectonicallycontrolled regression captured by changes in carbonate skeletal associations on a structured island shelf (mid-Pleistocene, Rhodes, Greece). Sedimentary Geology 283: 15-33.

https://doi.org/10.1016/j.sedgeo.2012.11.001

Underwood C.J., Mitchell S.F. \& Veltkamp C.J. 1999. Microborings in mid-Cretaceous fish teeth. Proceedings of the Yorkshire Geological Society 52: 269-274. https://doi.org/10.1144/pygs.52.3.269

Vénec-Peyré T.-M. 1996. Bioeroding foraminifera: a review. Marine Micropaleontology 28: 19-30.

Verde M. 2002. Icnología de la Formación Camacho (Mioceno Tardio) del Uruguay. Unpublished MSc Thesis. Universidad de la República, Montevideo, Uruguay.

Vermeij G.J. 1977. The Mesozoic Marine Revolution: evidence from snails, predators and grazers. Paleobiology 3: 245-258.

Vogel K. 1987. Bohrorganismen und Fazies im Mitteldevon des Staates New York, USA. Natur und Museum 117: 207-216.

Vogel K. \& Brett C.E. 2009. Record of microendoliths in different facies of the Upper Ordovician in the Cincinnati Arch region USA: The early history of light-related microendolithic zonation. Palaeogeography, Palaeoclimatology, Palaeoecology 281: 1-24. https://doi.org/10.1016/j.palaeo.2009.06.032 
Vogel K. \& Glaub I. 2004. 450 Millionen Jahre Beständigkeit in der Evolution endolithischer Mikroorganismen? Sitzungsberichte der Wissenschaftlichen Gesellschaft an der Johann Wolfgang Goethe-Universität Frankfurt am Main 42: 1-42.

Vogel K. \& Marincovich L. 2004. Paleobathymetric implications of microborings in Tertiary strata of Alaska, USA. Palaeogeography, Palaeoclimatology, Palaeoecology 206: 1-20. https://doi.org/10.1016/j.palaeo.2003.12.017

Vogel K., Golubic S. \& Brett C.E. 1987. Endolith associations and their relation to facies distribution in the Middle Devonian of New York State, USA. Lethaia 20: 263-290. https://doi.org/10.1111/j.1502-3931.1987.tb02047.x

Voigt E. 1929. Die Lithogenese der Flach- und Tiefwassersedimente des jüngeren Oberkreidemeeres, eine Parallelisierung orogenetisch bedingter Ablagerungsverhältnisse am Harzrand in Südschweden und im preussisch-holländischen Grenzgebiet. Jahrbuch des Halleschen Verbandes für die Erforschung der mitteldeutschen Bodenschätze und ihrer Verwertung 8: 1-162.

Voigt E. 1972. Über Talpina ramosa v. Hagenow 1840, ein wahrscheinlich zu den Phoronidea gehöriger Bohrorganismus aus der Oberen Kreide, nebst Bemerkungen zu den übrigen bisher beschriebenen kretazischen "Talpina"-Arten. Nachrichten der Akademie der Wissenschaften II, Mathematischphysikalische Klasse 7: 93-126.

Walker S.E., Hancock L.G. \& Bowser S.S. 2017. Diversity, biogeography, body size and fossil record of parasitic and suspected parasitic foraminifera: a review. Journal of Foraminiferal Research 47: 34-55. https://doi.org/10.2113/gsjfr.47.1.34

Webby B.D., Paris F., Droser M. \& Percival I.G. 2004. The Great Ordovician Biodiversification Event. Columbia University Press, New York.

Whittlesea P.S. 2005. First record of phragmocone and alveolar cavity of the chalk belemnite Gonioteuthis. Bulletin of the Geological Society of Norfolk 54: 15-23.

Wilson M.A. 2007. Macroborings and the evolution of marine bioerosion. In: Miller III W. (ed.) Trace Fossils: Concepts, Problems, Prospects: 356-367. Elsevier, Amsterdam.

https://doi.org/10.1016/B978-044452949-7/50146-7

Wilson M.A. \& Palmer T.J. 2006. Patterns and process in the Ordovician Bioerosion Revolution. Ichnos 13: $109-112$.

Wilson M.A., Feldman H.R. \& Krivicich E.K. 2010. Bioerosion in an equatorial Middle Jurassic coral-sponge reef community (Callovian, Matmor Formation, southern Israel). Palaeogeography, Palaeoclimatology, Palaeoecology 289: 93-101. https://doi.org/10.1016/j.palaeo.2010.02.019

Wisshak M. 2006. High-Latitude Bioerosion: The Kosterfjord Experiment. Lecture Notes in Earth Sciences 109. Springer, Heidelberg. https://doi.org/10.1007/978-3-540-36849-6

Wisshak M. 2008. Two new dwarf Entobia ichnospecies in a diverse aphotic ichnocoenosis (Pleistocene/Rhodes, Greece). In: Wisshak M. \& Tapanila L. (eds) Current Developments in Bioerosion: 213-233. Springer, Heidelberg. https://doi.org/10.1007/978-3-540-77598-0_11

Wisshak M. 2012. Microbioerosion. In: Knaust D. \& Bromley R.G. (eds) Trace Fossils as Indicators of Sedimentary Environments: 213-243. Elsevier, Amsterdam.

https://doi.org/10.1016/B978-0-444-53813-0.00008-3

Wisshak M. \& Rüggeberg A. 2006. Colonisation and bioerosion of experimental substrates by benthic foraminiferans from euphotic to aphotic depths (Kosterfjord, SW Sweden). Facies 52: 1-17.

https://doi.org/10.1007/s10347-005-0033-1 
Wisshak M., Freiwald A., Lundälv T. \& Gektidis M. 2005a. The physical niche of bathyal Lophelia pertusa in a non-bathyal setting: environmental controls and palaeoecological implications. In: Freiwald A. \& Roberts J.M. (eds) Cold-Water Corals and Ecosystems: 979-1001. Springer, Heidelberg. https://doi.org/10.1007/3-540-27673-4_49

Wisshak M., Gektidis M., Freiwald A. \& Lundälv T. 2005b. Bioerosion along a bathymetric gradient in a cold-temperate setting (Kosterfjord, SW Sweden): an experimental study. Facies 51: 93-117. https://doi.org/10.1007/s10347-005-0009-1

Wisshak M., Seuss B. \& Nützel A. 2008. Evolutionary implications of an exceptionally preserved Carboniferous microboring assemblage in the Buckhorn Asphalt lagerstätte (Oklahoma, USA). In: Wisshak M. \& Tapanila L. (eds) Current Developments in Bioerosion: 21-54. Springer, Heidelberg. https://doi.org/10.1007/978-3-540-77598-0_2

Wisshak M., Tribollet A., Golubic S., Jakobsen J. \& Freiwald A. 2011. Temperate bioerosion: ichnodiversity and biodiversity from intertidal to bathyal depths (Azores). Geobiology 9: 492-520. https://doi.org/10.1111/j.1472-4669.2011.00299.x

Wisshak M., Neumann C., Knaust D. \& Reich M. 2017. Rediscovery of type material of the bioerosional trace fossil Talpina von Hagenow, 1840 and its ichnotaxonomical implications. Paläontologische Zeitschrift 91: 127-135. https://doi.org/10.1007/s12542-017-0335-y

Zeff M.L. \& Perkins R.D. 1979. Microbial alteration of Bahamian deep-sea carbonates. Sedimentology 26: 175-201.

Zittel K. 1879. Studien über fossile Spongien. Dritte Abtheilung: Monactinellidae, Tetractinellidae und Calcispongiae. Abhandlungen der mathematisch-physikalischen Classe der königlich bayerischen Akademie der Wissenschaften 13: 91-138.

Manuscript received: 2 June 2016

Manuscript accepted: 5 July 2017

Published on: 29 December 2017

Topic editor: Christian de Muizon

Desk editor: Danny Eibye-Jacobsen

Printed versions of all papers are also deposited in the libraries of the institutes that are members of the EJT consortium: Muséum national d'Histoire naturelle, Paris, France; Botanic Garden Meise, Belgium; Royal Museum for Central Africa, Tervuren, Belgium; Natural History Museum, London, United Kingdom; Royal Belgian Institute of Natural Sciences, Brussels, Belgium; Natural History Museum of Denmark, Copenhagen, Denmark; Naturalis Biodiversity Center, Leiden, the Netherlands; Museo Nacional de Ciencias Naturales-CSIC, Madrid, Spain; Real Jardín Botánico de Madrid CSIC, Spain. 